UNIVERSIDADE DE SÃO PAULO

FACULDADE DE EDUCAÇÃO

\author{
LIDIA GODOI
}

\title{
PRÁTICAS EDUCATIVAS ENTRE PARES \\ Estudo do trabalho diário de professoras em um Centro de Educação Infantil paulistano
}




\section{LIDIA GODOI}

\section{PRÁTICAS EDUCATIVAS ENTRE PARES \\ Estudo do trabalho diário de professoras em um Centro de Educação Infantil paulistano}

Dissertação apresentada ao Programa de Pós-Graduação em Educação da Faculdade de Educação da Universidade de São Paulo, como exigência parcial para obtenção do título de Mestre em Educação.

Área de Concentração: Didática, Teorias de Ensino e Práticas Escolares.

Orientadora: Prof. $^{\text {a }}$ Dr. ${ }^{\text {a }}$ Mônica Appezzato Pinazza. 
AUTORIZO A REPRODUÇÃO E DIVULGAÇÃO TOTAL OU PARCIAL DESTE TRABALHO, POR QUALQUER MEIO CONVENCIONAL OU ELETRÔNICO, PARA FINS DE ESTUDO E PESQUISA, DESDE QUE CITADA A FONTE.

Catalogação na Publicação

Serviço de Biblioteca e Documentação

Faculdade de Educação da Universidade de São Paulo

372.21(81.61) Godoi, Lidia

G588p Práticas educativas entre pares: estudo do trabalho diário de professoras em um centro de educação infantil paulistano/ Lidia Godoi; orientação Mônica Appezzato Pinazza. São Paulo: s.n., 2015. 314, p. ils; Apêndice.; tabs.; anexos

Dissertação (Mestrado - Programa de Pós-Graduação em Educação. Área de Concentração: Didática Teorias de Ensino e Práticas Escolares) - - Faculdade de Educação da Universidade de São Paulo.

1. Educação Infantil 2. Prática de Ensino 3. Formação Continuada de Professores 4. Planejamento (Educação) I. Pinazza, Mônica Appezzato, orient. 
Dissertação apresentada à Faculdade de Educação da Universidade de São Paulo como parte dos requisitos para obtenção do título de Mestre em Educação.

Aprovada em:

Banca Examinadora

Prof.Dr.: Instituição

Julgamento: Assinatura:

Prof.Dr.: Instituição

Julgamento: Assinatura:

Prof.Dr: Instituição

Julgamento: Assinatura: 
A Maria, Félix, Marcos, Murilo e Luisa, pelo amor incondicional, apoio e paciência. 


\section{Agradecimentos}

Agradeço a Deus e a todos e todas que, de alguma maneira, contribuíram para a realização desse trabalho, em especial:

à Prof ${ }^{a}$ Dra. Mônica Pinazza, que acolheu minhas limitações com paciência e generosidade e provocou muitas reflexões que me ajudaram a descobrir os caminhos trilhados durante a realização do trabalho;

à Prof ${ }^{a}$ Dra. Tizuko Kishimoto por suas contribuições para a minha formação enquanto profissional da Educação Infantil e pesquisadora;

à Prof ${ }^{a}$ Dra. Patrícia Dias Prado pela generosa contribuição feita por meio da análise da trajetória desenvolvida nesse estudo, fundamental para minha formação enquanto pesquisadora;

à Prof ${ }^{a}$ Dra. Márcia A. Gobbi por compartilhar comigo seus saberes e sobretudo por despertar em mim o desejo de ser pesquisadora;

à Dorli Basílio, grande parceira e fonte de inspiração, que com sua energia e amor mesmo distante se fez presente durante toda a minha trajetória enquanto pesquisadora.

ao Marcos por ter me oferecido apoio e amor incondicional. Sem você ao meu lado, segurando a minha mão, essa jornada teria sido muito mais difícil;

aos meus grandes amores Murilo e Luisa, que souberam suportar minhas ausências com paciência e me inspiraram a seguir;

a todos(as) colegas do grupo Contextos Integrados de Educação Infantil, por poder compartilhar saberes e experiência que muito contribuíram para a realização desse trabalho;

às colegas e amigas do CEI Cidade de Genebra, por dividirem comigo cotidianamente seus saberes, práticas e aflições;

às meninas, meninos, professoras e equipe gestora do CEI em que se deu a pesquisa, pelo acolhimento e sobretudo por compartilharem comigo seu dia-a-dia, suas conquistas e experiências; 
e, por fim, aos amigos e amigas e família que, de perto ou de longe, direta ou indiretamente, participaram dessa conquista. 


\section{RESUMO}

O presente trabalho de pesquisa teve como objeto de estudo as práticas cotidianas vivenciadas por quatro professoras e um agrupamento de 24 crianças com idades de 2 a 3 anos, em um Centro de Educação Infantil (CEI) público do município de São Paulo. A investigação se comprometeu essencialmente com três questões, a saber: Como se constitui a organização das práticas educativas partilhadas por duas duplas de professoras que se revezam nos períodos da manhã e da tarde em um mesmo agrupamento de crianças? Há espaço para comunicação entre elas? Em que medida as práticas propostas compõem uma rotina flexível e orientada por um planejamento comum, de forma a propiciar às crianças experiências de aprendizagem expressivas pautadas na continuidade e na interação? Trata-se de uma pesquisa pedagógica qualitativa que adota a perspectiva de um estudo de caso único, tal como proposta por Yin. Como fontes de dados, foram considerados: o Projeto Político Pedagógico em que consta o plano de formação das professoras; os planejamentos e registros das professoras; o diário de bordo da pesquisadora, bem como as entrevistas realizadas com as professoras e gestoras da unidade estudada. A análise e discussão dos dados produzidos foram realizadas à luz do conceito de experiência elaborado por John Dewey. Também foram utilizados os aportes teóricos presentes nas obras de OliveiraFormosinho, Barbosa, Kishimoto. O presente estudo trouxe algumas importantes evidências a respeito do processo formativo no âmbito do CEI, especialmente, no tocante às circunstâncias estruturais e organizativas. Os tempos e espaços restritos de comunicação e de reflexão sobre as questões da prática revelaram-se determinantes da fragmentação dos planejamentos das professoras acompanhadas. Os planejamentos pouco articulados resultam em experiências que, além de descontínuas, interagem escassamente com as situações cotidianas, o que termina por aproximá-las de um currículo pautado na "lógica das disciplinas". O estudo destaca a necessidade de se ampliar as pesquisas sobre a rede municipal de educação, de forma a subsidiar as políticas publicas para educação infantil e a formação contínua realizada no contexto das instituições. Por fim, defende-se a importância de se garantir legalmente condições institucionais para que a reflexão coletiva em busca do aprimoramento das práticas com as crianças sejam efetivadas no contexto dos CEIs. 
Palavras-chave: Educação infantil. Creche. Currículo, Planejamento, Formação continuada de professores.

\section{ABSTRACT \\ EDUCATIVE PRACTICES AMONG PEERS: A study of the daily work of teachers at a Day Care Center in the city of Sao Paulo}

This study had the purpose of investigating everyday practice of four teachers and a group of 24 children aged 2 through 3 years, in a public Day Care Center (CEI) in the city of de São Paulo. The research involved basically three dimensions, that is: How educational practices are organized when shared by pairs of teachers who alternate in the morning and afternoon shifts in the same group of children? Is there room for communication between them? To what extent the proposed practices make up a flexible routine oriented by some shared planning, in order to provide children with significant learning experiences based on continuity and interaction? This is, therefore, a qualitative pedagogical research that adopts the perspective of a single case study, as proposed by Yin. The following sources of data were included: the Political Pedagogical Project which the training plan for the teachers was a part of; the planning and records by the teachers; the researcher's logbook, as well as the interviews with the teachers and managers at the school I have studied. The analysis and discussion of data were conducted in the light of the concept of experience defined by John Dewey. Other theoretical approaches were also utilized, found in the works of Oliveira-Formosinho, Barbosa, and Kishimoto. This study brought some important evidence concerning the formative process within a Day Care Center (CEI), especially in regard of structural and organizational circumstances. Restricted times and spaces of communication and reflection about the issues arising of the practice turned out to be determining of the fragmentation in the planning made by the teachers whose actions I have followed. Planning was poorly articulated and resulted in experiences that were not only discontinuous but they also scarcely interacted with everyday situations, which in the end put them close curriculum based on the "logic of disciplines". The study highlights the need to enhance the research on the city's educational system, in order to give 
subsidies for the public policies aimed at children's education and the ongoing formation that is conducted within the schools. Finally, I stand for the importance of legally guaranteeing institutional conditions so that the collective reflection to improve the pedagogical practices with children can be effected in the context of CEIs.

Keywords: Day Care Center. Curriculum. Planning. Continued Trainning of Teachers. 


\section{SUMÁRIO}

AGRADECIMENTOS

$\begin{array}{ll}\text { RESUMO } & 7\end{array}$

1 INTRODUÇÃO

2 CRECHES BRASILEIRAS: UM OLHAR SOBRE AS 16 PROPOSTAS CURRICULARES

2.1 Primeiras creches no Brasil: filantropia, cuidado e assistência 16

2.2 Creche integrante da educação infantil: história de luta pelo estatuto 20 institucional

2.3 Creches no sistema educacional paulistano: outro olhar para a 33 educação das crianças pequenas

2.4 Profissionais de Creche/CEI: breve histórico da profissão e 47 circunstâncias atuais

3 PROPOSTAS CURRICULARES PARA AS CRECHES: INSPIRAÇÕES E PRÁTICAS PRESENTES

3.2 As matrizes pedagógicas e suas relações com as construções 61 curriculares para a primeira Infância

3.3 Abordagens curriculares para Educação Infantil: inspirações da 64 High/Scope, Reggio Emilia, Movimento da Escola Moderna e Pedagogia em Participação

3.3.1 Abordagem High/Scope $\quad 64$

3.3.2 Abordagem curricular de Reggio Emilia 66

3.3.3 Abordagem Curricular para Educação infantil da Escola 69 Moderna Portuguesa

3.3.4 Pedagogia-em-Participação: Abordagem da Associação Criança 72 para a Infância 
3.4 O contexto do município de São Paulo: Currículo Integrado para a 74 Primeira Infância

\section{CONTEXTO E CAMINHOS DA PESQUISA EMPÍRICA 78}

$\begin{array}{ll}4.1 & \text { Caminho metodológico } \\ & 78\end{array}$

4.2 Contexto da pesquisa 79

$\begin{array}{ll}4.3 \text { Produção de dados } & 91\end{array}$

4.4 A triangulação de fontes de dados 93

5 CENTRO DE EDUCAÇÃO INFANTIL EM ESTUDO: 97 CURRÍCULO VIVIDO NOS PLANOS DE QUATRO PROFESSORAS

5.1 Projeto Político Pedagógico e Plano de Formação das Professoras 97

5.2 Entrevistas com as quatro professoras, coordenadora pedagógica e 102 diretora

5.3 Planos de Trabalho e Registro das Professoras 108

5.4 Registros no Diário de Campo da Pesquisadora 113

5.4.1 O projeto animais $\quad 117$

5.4.2 Áreas de interesse, uma constante durante o período da tarde $\quad 119$

$\begin{array}{ll}\text { 5.4.3 Os Momentos de Brincadeiras Livres } & 123\end{array}$

5.4.3.1 A brincadeira do Cachorro 123

$\begin{array}{ll}\text { 5.4.3.2 Saltos sobre o escorregador } & 128\end{array}$

6 CONSIDERAÇÕES FINAIS 132

$\begin{array}{lr}\text { REFERENCIAS } & 138\end{array}$

$\begin{array}{ll}\text { APÊNDICES } & 146\end{array}$

$\begin{array}{ll}\text { ANEXOS } & 306\end{array}$ 


\section{INTRODUÇÃO}

"Daí então, que a nossa presença no mundo, implicando escolha e decisão, não seja uma presença neutra". (FREIRE, 2000, p. 33)

Este trabalho tem como objeto de estudo as práticas cotidianas vivenciadas por um agrupamento ${ }^{1}$ de 24 crianças com idades de 2 a 3 anos e quatro professoras, em um Centro de Educação Infantil (CEI) público do município de São Paulo.

A escolha da temática, como diria Freire (2000), esteve carregada de motivações e sentidos presentes na trajetória pessoal e profissional da pesquisadora que, atuando no campo em foco, interessou-se por compreender os processos que compõem o cotidiano vivido nos espaços institucionais da educação infantil, em especial, das creches.

A realização de mais pesquisas no campo da educação infantil, particularmente a dedicada às crianças de 0 a 3 anos, é fundamental não somente para se compreender a realidade peculiar dessa etapa educacional, mas também para a constituição de uma Pedagogia da Infância. A convicção de que uma discussão profunda sobre o currículo vivido (ABUCHAIM, 2012) no espaço educativo das creches pode nos aproximar desse objetivo determinou o trajeto teórico-metodológico adotado nesta investigação.

Nesse sentido, a investigação está pautada na concepção da criança como sujeito histórico-social, capaz, inteligente e criativo (VYGOTSKY, 1998), reconhecendo o Centro de Educação Infantil como um espaço de educação e cuidado, apto a proporcionar experiências diversas que considerem as especificidades das crianças pequenas de 0 a 3 anos (OLIVEIRA-FORMOSINHO, 2000; PINAZZA, 2004; BARBOSA, 2006; KISHIMOTO, 2008; KRAMER, 2008). Parte-se da concepção de que o fazer pedagógico é uma prática específica que deve propiciar às crianças experiências educativas que, além de interagirem com as condições situacionais em que estas ocorrem, devem ter a potência de engendrar experiências mais e mais ampliadas (DEWEY, 1980; PINAZZA, 2007; OLIVEIRA-FORMOSINHO, 2011), resultando crescentemente em novas aprendizagens e em saberes de diferentes naturezas (BARBOSA, 2006, 2010; ZABALZA, 1998).

Para viabilizar tal investigação, firmou-se um processo colaborativo com um CEI municipal da cidade de São Paulo que mantém uma parceira com o grupo de

\footnotetext{
${ }^{1}$ Utiliza-se esse termo para referir-se aos grupos de crianças separadas em turmas que compõe o CEI.
} 
pesquisas Contextos Integrados de Educação Infantil ${ }^{2}$. A escolha por um estudo de caso único na vertente da pesquisa pedagógica qualitativa se ampara nos pressupostos metodológicos de alguns autores como Bogdan e Biklen (1999), Lankshear e Knobel (2008), Yin (2005) e Gomèz, Flores e Jimènez (1996).

O estudo de caso único acompanhou durante o período de seis meses um agrupamento de 24 crianças, com idades entre 2 e 3 anos, e as duas duplas de professoras por ele responsável a fim de compreender tanto o seu cotidiano quanto a maneira como essas duplas, que trabalham em períodos diferentes, organizam suas práticas educativas por meio de um planejamento comum voltado para o mesmo agrupamento. Ademais, este estudo se compromete com as seguintes questões: Há espaço para comunicação entre as professoras? As práticas propostas compõem uma rotina flexível? Em que medida? O planejamento comum proporciona às crianças experiências de aprendizagem expressivas?

Este estudo parte da suposição básica de que ações articuladas dentro de planejamento partilhado pelas duplas de professoras responsáveis por um mesmo agrupamento pode favorecer experiências que, atendendo aos princípios de continuidade e de interação anunciados por Dewey (1980) mostrem-se mais expressivas para as crianças. Entende-se, portanto, que as experiências das crianças podem ser qualitativamente distintas. Por isso, considera-se fundamental não só prover tempos de formação contínua realizada no CEI, mas garantir que esses tempos sejam organizados de sorte a contemplar o encontro entre as duas duplas, destinados à reflexão partilhada sobre as práticas educativas desenvolvidas em um e em outro período.

A pesquisa empírica ocorreu durante o ano de 2013 e constou de 12 sessões de observação realizadas. No entanto, antes de iniciar esse trabalho, foram realizadas visitas à unidade onde a observação ocorreria a fim de conhecer a equipe de educadores, momento em que foram colhidos dados documentais como o Projeto Político Pedagógico. Durante o trabalho de campo, os dados colhidos foram registrados inicialmente em bloco de notas e, em seguida, passados ao diário de bordo; também foram realizadas as entrevistas semiestruturadas e coletados os relatórios das professoras.

Cada fonte de dados utilizada na pesquisa ocasionou ponderações sobre as questões com que se comprometeu o estudo. Elaboradas conforme os dados iam sendo

\footnotetext{
${ }^{2}$ Grupo de Pesquisa na área da Educação Infantil e Formação de professores(as) - FEUSP coordenado pelas professoras Tizuko Morchida Kishimoto e Mônica Appezzato Pinazza.
} 
coletados, as categorias de análise os agrupam por similaridade e relevância para a elucidação das questões da pesquisa (LANKSHEAR \& KNOBEL, 2008).A análise e discussão dos dados produzidos foram realizadas à luz do conceito de experiência de Dewey (1980), que se assenta nos princípios de continuidade e interação.

O exame do Projeto Político Pedagógico da unidade permitiu compreender o plano de formação das professoras/ $\mathrm{PEA}^{3}$ e sua forma de organização, bem como a organização curricular pretendida. As entrevistas revelaram como as professoras e as gestoras percebem a realização desse processo de formação na própria unidade e em que medida as professoras conseguem trocar experiências e articular o planejamento nesse tempo de formação. Foi possível, além disso, perceber como as profissionais entrevistadas percebem seu próprio trabalho e as realizações das crianças nos dois períodos em que permanecem no CEI.

A análise dos planos de trabalho e registros das quatro professoras permitiu identificar como são documentadas as ações e produções das crianças, assim como apontou em que medida há possibilidade de se construir um planejamento articulado e factível. Por fim, os registros em diário de bordo da pesquisadora forneceram subsídios adicionais para compreender o quanto o planejamento se revela nas ações com as crianças, possibilitando um maior entendimento sobre a sua experiência no cotidiano do CEI.

O presente estudo trouxe algumas importantes evidências a respeito do processo formativo no âmbito do CEI, especialmente no tocante às circunstâncias estruturais e organizativas. A restrição imposta aos tempos e espaços destinados à comunicação e reflexão sobre as questões da prática das duplas consideradas no estudo revelou-se um fator determinante da fragmentação do planejamento comum. Por sua vez, planejamentos pouco articulados resultam em experiências descontínuas cuja interação com seus contextos é escassa. Disso conclui-se que, muito embora as crianças observadas vivenciem experiências interessantes, essas assumem um caráter muito mais pontual, localizado, à semelhança do que ocorre num currículo estruturado pela lógica das "disciplinas".

Este trabalho está organizado em seis capítulos a contar desta Introdução. No capítulo 2 é apresentado um breve histórico das creches, com foco especial nas proposições relativas ao currículo específico para essa etapa educacional. O capítulo 3

\footnotetext{
${ }^{3}$ PEA, Projetos Especiais de Ação, fonte do modelo de formação utilizada pela unidade.
} 
traz uma recapitulação acerca dos diferentes modelos curriculares destinados à educação infantil, com relevo àqueles que influenciaram (e influenciam) sobremaneira as propostas curriculares vigentes em âmbito nacional e municipal. No capítulo 4, apresenta-se o traçado metodológico do estudo, trazendo um reconhecimento do contexto estudado e a indicação dos métodos empregados na produção de dados. O capítulo 5 reúne a análise e a discussão dos dados produzidos durante a investigação, efetuando, num primeiro momento, uma apreciação dos elementos desvelados pelo exame de cada uma das fontes consideradas isoladamente e, em seguida, um cruzamento entre os dados obtidos visando uma análise do conjunto. As Considerações Finais compõem o capítulo 6. 


\section{AS CRECHES BRASILEIRAS: UM OLHAR SOBRE AS PROPOSTAS CURRICULARES}

A reconstituição da história social das creches, instituições definidas pelo compromisso com o cuidado e a educação de bebês e crianças muito pequenas, pode auxiliar na compreensão da configuração atual das práticas educativas que elas abrigam.

Este capítulo pretende tratar da trajetória histórica das creches brasileiras e, em especial, das paulistanas, enfocando as proposições curriculares relativas a essa etapa educacional, desde a década de 70 até os dias de hoje.

\subsection{Primeiras creches no Brasil: filantropia, cuidado e assistência.}

A história da educação infantil brasileira tem se constituído em objeto de estudo de importantes pesquisas realizadas no campo educacional, destacadamente a partir da década de 1980. Particularmente a respeito das creches, vários estudiosos têm se dedicado à tarefa de esclarecer em que bases se assentaram as justificativas para o surgimento dessas instituições e como, com o passar dos tempos, foram ganhando nova configuração no cenário das políticas públicas para a infância de 0 a 3 anos. Ajudam a compor essa história, pesquisadores como: Rosemberg (1984), Oliveira (1988), Kishimoto (1988), Haddad (1991), Campos; Rosemberg; Ferreira (1995), Kuhlmann Jr. (1998); Sanches (2003). Sem o intuito de refazer os caminhos percorridos por esses estudiosos, julgou-se conveniente recuperar alguns elementos do percurso cumprido pelas creches com o propósito de se compreender melhor: como essas instituições foram se constituindo como espaço educacional; quais concepções permearam o atendimento oferecido às crianças ao longo dos tempos; e, por fim, quando e como surgiram as primeiras preocupações com o currículo para essa etapa educacional.

Sabe-se que, no Brasil, as creches surgiram em um contexto de mudanças política, social e econômica, marcado, entre outros fatores, pelo fim da escravidão, chegada de imigrantes europeus, industrialização, surgimento das camadas médias e crescimento do proletariado. Acompanhando e impulsionando esse processo, a expansão capitalista trouxe a crescente urbanização e a necessidade de reprodução da força de trabalho. Nesse quadro, as transformações no trabalho feminino, com a entrada da mulher no mercado de trabalho e suas consequências para a maternidade, também aparecem como fatores determinantes na constituição histórica dessas instituições (HADDAD, 1991; 
KUHLMANN JR., 1998) cuja origem está diretamente relacionada com as preocupações sanitárias e filantrópicas tal como formuladas, sobretudo, pela medicina e assistência social (HADDAD, 1991; KISHIMOTO, 1988; KUHLMANN JR., 1998).

Como afirmam Campos, Ferreira e Rosemberg (1995), o atendimento em creches acontecia de forma fragmentada, promovido por diversos órgãos que não estabeleciam um diálogo entre si de forma a construir uma política única de atendimento à infância. $\mathrm{O}$ Ministério do Interior, em 1989, reunia três órgãos responsáveis pelo atendimento das crianças de 0 a $6 \operatorname{anos}^{4}$, sendo esses: a Fundação Legião Brasileira de Assistência (LBA); Fundação Nacional de Bem Estar do Menor (FUNABEM) e a Secretaria Especial de Ação Comunitária (SEAC).

A princípio, a LBA fixava suas ações nos serviços de assistência social, mas passou a atuar de forma mais sistemática no contexto das creches a partir da criação do Projeto Casulo, que transformou-se gradativamente no principal programa de creches do país. Desde sua fixação até 1987, o Programa de Creches da LBA manteve algumas características estáveis. Tratava-se de um programa nacional (provavelmente único), seja por sua abrangência territorial, seja pelo fato de definir metas nacionais de atendimento. Apesar da diversidade das creches vinculadas ao programa, sua opção foi atuar por meio de convênios, repassando verbas às prefeituras ou a instituições privadas. Era atendida prioritariamente a população de baixa renda, em jornadas diárias que variavam entre 4 e 8 horas. A instalação dessas creches era, por vezes, orientada por uma concepção preventiva e compensatória de educação infantil, preocupada em ocupar os espaços "ociosos” da comunidade (CAMPOS; FERREIRA; ROSEMBERG, 1995).

A FUNABEM também atuava no atendimento às crianças de 0 a 6 anos, estabelecendo, assim como a LBA, convênios para a criação de creches. Contudo, como assinalam Campos, Ferreira e Rosemberg (1995), a FUNABEM apresentava parâmetros para realização de convênios muito mais flexíveis, tanto no que diz respeito ao tipo de atendimento oferecido pela instituição como na questão das verbas alocadas.

Ligada ao Ministério da Habitação e Bem Estar Social, a SEAC atuava desenvolvendo programas destinados à saúde e à nutrição da população de 0 a 6 anos e subprogramas de creches comunitárias. Repassava a essas creches recursos financeiros destinados à construção de prédios e aquisição de materiais como lençóis e fraldas.

\footnotetext{
${ }^{4}$ Usa-se 0 a 6 como referência à faixa etária atendidas na época em creches e pré-escolas de forma indiscriminada, pois não havia ainda uma divisão entre as faixas etárias atendidas em cada instituição.
} 
No âmbito do Ministério da Educação (MEC), praticamente inexistia uma política educacional para as crianças de 0 a 6 anos, haja vista a Lei de Diretrizes e Bases da Educação Nacional $\mathrm{n}^{\mathrm{o}} 5.692 / 71$, a qual trazia apenas vagamente a ideia de que os sistemas de ensino velariam pela educação das crianças com idades inferior a 7 anos em escolas maternais, jardins de infância e instituições equivalentes (Ibidem, 1995). Até então, as creches não ocupavam a atenção das políticas educacionais, não havendo nem mesmo uma diferenciação por faixa etária.

De acordo com Campos, Ferreira e Rosemberg (Ibid., p. 45),

Em 1974 o MEC constituiu um grupo de estudos do qual resultou uma proposta (que se situou neste nível) de categorização do atendimento por faixa etária: 0 a 1 ano, creches; 2 a 3 anos, escolas maternais; 4 a 6 anos, jardins de infância. Esta categorização não foi incorporada, seja em nível federal, seja no nível das Secretarias Estaduais ou Municipais de Educação. Por exemplo: o Ministério da Saúde reserva o atendimento em creches para crianças entre 3 meses e 4 anos [...] No município de São Paulo, a Secretaria da Promoção Social mantém uma rede de creches que atende crianças até 6 anos e 11 meses [...].

A educação infantil no Brasil, portanto, ocupava um lugar bastante periférico no cenário político. Isso se revelava também pela ausência de espaço no plano governamental em sua esfera mais ampla. Inexistia um planejamento que se dedicasse ao delineamento, em âmbito nacional, de questões relacionadas ao cuidado e à educação das crianças de 0 a 6 anos e que tematizasse os atendimentos em creches e pré-escola, orientando o funcionamento dessas instituições e indicando possibilidades para os programas voltados a essa faixa etária. Como decorrência, os municípios tiveram trajetórias peculiares no que tange à constituição da rede de creches.

Assim foi em São Paulo. As particularidades da constituição histórica das creches nessa cidade a destacam entre os demais municípios brasileiros no que diz respeito ao atendimento à criança pequena. Em São Paulo, a demanda pela criação de uma rede de creches que oferecesse atendimento duradouro, e não somente emergencial surge mais fortemente a partir da década de 70, quando emerge o Movimento de Luta por Creches. Tal movimento foi deflagrado pela sociedade civil, representada, em geral, por mulheres, empregadas domésticas, donas de casa, operárias, grupos feministas e intelectuais. A proposta do movimento era a criação de uma rede de creches totalmente mantida pelo Estado e que tivesse a participação da comunidade, desde a orientação pedagógica até a escolha de seus funcionários (HADDAD, 1991). Aos poucos, as 
camadas populares ganharam o reconhecimento por parte dos órgãos oficiais de se apropriarem de bens e serviços públicos.

As reivindicações do Movimento foram significativamente atendidas pelo poder público Municipal, através da Coordenadoria do BemEstar Social (COBES), dando início à expansão de uma rede de creches mantida totalmente pelo município (Ibid., p. 31).

De acordo com Rosemberg, Campos e Haddad (1991), as creches paulistanas então estavam à frente de suas congêneres de outros municípios, por já disporem de estrutura administrativa que estabelecia diretrizes gerais para seu funcionamento, bem como de sistematização e padronização de seu projeto arquitetônico, programação e quadro de pessoal.

No que tange às propostas educativas formuladas pelo Movimento de Luta por Creches, essas seguiam uma linha de educação compensatória, na época, em vigor no órgão do Bem-Estar Social. Contudo, à medida que a rede de creches no município crescia, aumentavam os questionamentos sobre as práticas, buscando-se novos caminhos e experimentando-se modelos inovadores, o que sinalizava uma preocupação com a questão educacional (HADDAD, 1991). Desta maneira, em 1984, a FABES Secretaria da Família e Bem Estar Social, publica o documento "Proposta de Reprogramação de Creches", que trazia a concepção de creche como equipamento social e espaço de convivência e de desenvolvimento do processo educativo, compreendendo suas dimensões social, pedagógica e política. Posteriormente, a Secretaria do Bem Estar Social (SEBES) retoma alguns princípios do referido documento estabelecendo que a programação pedagógica nas creches deveria contemplar a criança na sua globalidade e, entendendo-a como um ser em desenvolvimento, buscar a satisfação de suas necessidades básicas e respeitar seus momentos cognitivos, afetivos e sociais. A proposta de trabalho com as crianças na creche deveria basear-se na concepção de que o conhecimento se constrói numa relação de troca entre aqueles que educam e os que são educados. Essa interação, guiada pela observação e sensibilidade do adulto com relação a cada etapa do desenvolvimento infantil, tornaria possível o desenvolvimento autônomo dos níveis de pensamento e comportamento das crianças. Nesse sentido, os espaços das instituições deveriam ser organizados de forma a assegurar a liberdade de ação e expressão das crianças, bem 
como a vivência de experiências variadas (ROSEMBERG; CAMPOS; HADDAD, 1991).

Portanto, havia no município um movimento para repensar a creche: não somente como espaço de cuidado físico das crianças ali atendidas, mas também um espaço de educação, aprendizado e convivência social.

\subsection{Creche integrante da educação infantil: história de luta pelo estatuto institucional}

Havia no país uma pressão feita por vários segmentos da população para obter o reconhecimento da demanda por cuidado e educação das crianças de 0 a 6 anos como um direito.

A década de 1980 intensificou os debates a respeito da educação das crianças pequenas, entre elas as de 0 a 3 anos. Dessa forma, em setembro de 1981, o Departamento de Pesquisas Educacionais da Fundação Carlos Chagas realizou vários encontros de abrangência nacional com vistas a conhecer e discutir as experiências de creche no Brasil e também compreender a natureza do trabalho das pajens (ROSEMBERG, 1984; LIMA et al., 1984).

As discussões giravam em torno de uma concepção integrada para a educação da criança de 0 a 6 anos. Tanto Rosemberg (1984) como Campos (1986) defendiam o atendimento dessas crianças em creches e pré-escolas públicas. Além disso, sustentavam que esse atendimento não se configurasse unicamente como resposta ao direito da mulher, mas também como uma exigência relativa ao direito das crianças à educação. Advertem que a creche é um direito tanto da criança como da mãe trabalhadora. Tais ponderações foram influenciadas pelas demandas sociais colocadas à época pelo movimento feminista representado pelo Conselho Estadual da Condição Feminina (CECF), que, na efervescência deste momento histórico, exige direito não só ao trabalho como à participação política e social. Desta maneira, reivindicam que toda a sociedade se responsabilize pela educação das novas gerações, colocando em xeque o papel tradicional da mulher na família. Além disso, ao incluir a creche na educação, está-se rompendo, ao menos ao nível do discurso, com seu caráter historicamente assistencialista, o que concorre para o entendimento da creche não como substituta da família, mas como uma alternativa (CAMPOS, 1999; FARIA, 2005; SANTOS, 2006).

Nesse contexto, no ano de 1988, a Constituição Federal assegura um estatuto institucional à educação da criança pequena, anunciando em seu artigo 205: 
Art. 205. A educação, direito de todos e dever do Estado e da família, será promovida e incentivada com a colaboração da sociedade, visando ao pleno desenvolvimento da pessoa, seu preparo para o exercício da cidadania e sua qualificação para o trabalho (BRASIL, 1988).

A oferta de educação infantil passou a ser dever do Estado em ação complementar à da família, efetivado mediante a garantia do atendimento à criança de 0 a 6 anos em creches e pré-escolas, conforme artigo 208, inciso IV (BRASIL, 1988).

Na esteira das determinações da Constituição Federal, o Ministério da Educação inicia uma série de ações visando à construção de uma política de educação infantil de abrangência nacional. No ano de 1994, após intensas discussões envolvendo segmentos governamentais e não governamentais, foi aprovada a Política Nacional de Educação Infantil (1994) ${ }^{5}$. Esse documento explicita os objetivos, diretrizes gerais e linhas de ação prioritárias que devem orientar as ações do MEC na educação Infantil de 0 a 6 anos. Estipula as diretrizes pedagógicas com vistas à promoção da melhoria de qualidade no atendimento às crianças, partindo do pressuposto de que a qualidade da educação infantil requer a implementação de ações sistemáticas com a garantia de que todas as relações construídas no interior das creches e pré-escolas sejam educativas (BARRETO, 1995).

Explicita-se, assim, a necessidade de que o trabalho seja orientado por propostas pedagógicas fundamentadas numa concepção de criança e de educação infantil e nos conhecimentos acumulados sobre os processos de desenvolvimento e aprendizagem na primeira etapa da vida humana (Ibidem, p.11).

A preocupação prioritária do MEC em relação às diretrizes propostas na Politica Nacional de Educação Infantil então recai sobre as questões curriculares. Dessa forma, juntamente com a Coordenadoria Geral de Educação Infantil (COEDI), o MEC passa a incentivar a construção de propostas pedagógicas e curriculares coerentes com os pressupostos constantes na Política Nacional de Educação Infantil. Contudo, era necessário conhecer o que já vinha sendo feito. Para tanto, em dezembro de 1994, determinou-se que MEC e COEDI constituíssem um grupo de trabalho formado por

\footnotetext{
${ }^{5}$ Esse documento foi reeditado no ano de 2006 considerando fatores presentes na legislação brasileira referentes ao Ensino Fundamental de 9 anos.
} 
técnicos do próprio Ministério, consultores e especialistas, com vistas a desenvolver uma metodologia de análise das propostas pedagógicas e curriculares em curso na educação infantil brasileira. Foram analisados 45 conjuntos de propostas, sendo 25 provenientes de sistemas estaduais e 20 de sistemas municipais, o que possibilitou um diagnóstico bastante representativo da realidade da educação infantil brasileira (BRASIL, 1996).

Dentre outros dados, constatou-se que, das 45 propostas enviadas, 39 pertenciam a pré-escolas, destinadas ao trabalho com crianças de 4 a 6 anos e, prioritariamente, com aquelas de 6 anos; cinco referiam-se a creches; e apenas uma era voltada à faixa etária de 0 a 6 anos. Por fim, cabe mencionar que, do total, duas propostas provinham da área social.

No que diz respeito às propostas voltadas à educação infantil de 0 a 3 anos, chegou-se à seguinte conclusão.

Dos documentos encaminhados, poucos se referem ao trabalho com crianças de 0 a 3 anos. Não se podendo concluir a partir daí, pela sua inexistência. No momento da avaliação da implementação das propostas, pôde-se confirmar uma hipótese levantada anteriormente, de que existiam propostas sistematizadas relativas ao trabalho de creche. De fato, essas propostas são elaboradas, em geral, pelas secretarias ligadas à área do desenvolvimento e promoção social (Ibid., p. 30).

As ações do MEC caminhavam para a construção de um novo olhar para a educação das crianças que frequentavam as creches e pré-escolas brasileiras. Com relação à creche, esse esforço de construção evidencia-se no ano de 1995 por meio do documento Critérios para um atendimento em creches que respeite os direitos fundamentais das crianças (BRASIL, 1995) ${ }^{6}$.

O mérito do referido documento é demonstrar uma clara defesa dos direitos das crianças e apresentar uma série de circunstâncias necessárias a um atendimento de maior qualidade. $\mathrm{O}$ envolvimento da equipe de pesquisas sobre creches da Fundação Carlos Chagas, representada pelas pesquisadoras Maria Malta Campos e Fúlvia Rosemberg, confere ao texto um olhar rigoroso sobre a questão curricular para a creche. O documento divide-se em duas seções. A primeira delas estabelece critérios relativos à organização e ao funcionamento interno das creches, voltados principalmente às

\footnotetext{
${ }^{6}$ Esse documento teve sua primeira edição em 1995 e foi reeditado em 2009. No presente texto, utilizaremos como referência a edição de 2009.
} 
práticas concretas adotadas no trabalho direto com as crianças. Na segunda parte, são apresentados critérios relativos à definição de diretrizes e normas políticas, programas e sistemas de financiamento de creches tanto governamentais como não governamentais (BRASIL, 2009c).

A intenção maior do documento foi afirmar o compromisso dos políticos, administradores e educadores de creches com o atendimento de qualidade voltado para as necessidades fundamentais das crianças, entre elas: brincadeira, ambiente aconchegante seguro e estimulante, saúde e alimentação, contato com a natureza e desenvolvimento de sua identidade social, cultural e religiosa (BRASIL, 2009).

Esse foi um importante passo para se pensar a construção de um currículo em que a criança é colocada no centro da ação educativa compreendida em sua integralidade, uma vez que os "Critérios para um atendimento em creches que respeite os direitos fundamentais das crianças" deixam claro que os direitos fundamentais das crianças pequenas só serão assegurados se as políticas e os programas estiverem comprometidos com o seu bem-estar e desenvolvimento (BRASIL, 2009).

Essa movimentação em torno da educação das crianças pequenas é reforçada com a promulgação da Lei de Diretrizes e Bases da Educação Nacional, Lei $\mathrm{n}^{\circ}$ 9.394/96, que reafirma os princípios do texto constitucional, ao definir a educação infantil como primeira etapa da educação básica.

Art. 29. A educação infantil, primeira etapa da educação básica, tem como finalidade o desenvolvimento integral da criança até seis anos de idade, em seus aspectos físico, psicológico, intelectual e social, complementando a ação da família e da comunidade.

Art. 30. A educação infantil será oferecida em:

I - creches, ou entidades equivalentes, para crianças de até três anos de idade;

II - pré-escolas, para as crianças de quatro a seis anos de idade (BRASIL, 1996).

No artigo 22 da LDB, apresenta-se como finalidade da educação básica: promover o desenvolvimento do educando, assegurando-lhe a formação comum indispensável para o exercício da cidadania e fornecendo-lhe meios para progredir no trabalho e em exercícios posteriores (BRASIL, 1996).

Ao incluir a educação infantil de 0 a 3 anos na educação básica, a LDB esclarece as concepções que sustentam um novo conceito relacionado ao atendimento em creches e pré-escolas. Tal concepção entende que a formação para o exercício da cidadania não 
se inicia a partir do momento em que a criança ingressa no ensino fundamental, mas em momentos anteriores, ainda no nascimento (DIDONET, 2000). Isso implica práticas pedagógicas que considerem as crianças pequenas em sua forma singular de ser e estar no mundo.

Com a promulgação da LDB/N 9394/1996, estabelece-se um prazo para que as creches possam integrar-se aos sistemas municipais de ensino, bem como se determina que essas instituições promovam práticas que contribuam para o desenvolvimento integral das crianças ali atendidas. Os enunciados expostos nesta lei alavancaram transformações já em curso no contexto do atendimento educacional em creches. Em nível nacional, o MEC editou, em 1998, o Referencial Curricular Nacional para a Educação Infantil (RCNEI), em creches e pré-escolas, propondo referências curriculares para a educação de 0 a 6 anos $^{7}$.

A despeito de ser uma primeira tentativa de se estabelecer um currículo nacional envolvendo as creches e pré-escolas brasileiras, o RCNEI sofreu inúmeras críticas direcionadas à sua organização emprestada do ensino fundamental (CERIZARA, 2007). O RCNEI, apesar de se apresentar unicamente como um referencial, foi amplamente disseminado entre os profissionais da área, embora não representasse uma preocupação real com a situação das crianças que frequentam as creches e pré-escolas brasileiras (KUHLMANN JR., 2007).

$\mathrm{Na}$ tentativa de construir uma proposta curricular que contemplasse os princípios que vinham sendo historicamente debatidos e constituídos em torno da educação infantil, o Conselho Nacional de Educação (CNE), por meio da Câmara de Educação Básica (CEB), instituiu no ano de 1999 as Diretrizes Curriculares Nacionais para a Educação Infantil (DCNEI), documento publicado por meio da Resolução $\mathrm{n}^{\circ} 1 / 1999 .{ }^{8}$

$\mathrm{O}$ texto das DCNEIs permaneceu às sombras dos RCNs no âmbito das instituições de educação infantil. No entanto, muito provavelmente pelo seu caráter mais abrangente e definitivamente não prescritivo, ressurgiu como foco de debates. Isso ocorreu quando da sua revisão e reedição por meio da Resolução no 5/2009, expressas no Parecer CNE/CEB $n^{\circ}$ 20/2009, que considera as mudanças na organização da educação brasileira ${ }^{9}$.

\footnotetext{
${ }^{7}$ Hoje, a educação infantil compreende a faixa etária de 0 a 5 anos, devido a mudanças posteriores no texto da LDB $\mathrm{n}^{\circ}$ 9.394/96.

${ }^{8} \mathrm{O}$ referido documento foi reeditado no ano de 2009. Nesse contexto, utilizam-se mais adiante fragmentos na versão reeditada.

9 Tais mudanças referem-se à Instituição do Ensino Fundamental de nove anos.
} 
As ações do MEC nesse momento histórico não se esgotaram na tentativa de construção de matrizes curriculares que pudessem nortear o trabalho nas unidades, mas avançaram no sentido de um movimento mais amplo de busca pela qualidade no atendimento. $\mathrm{O}$ conceito de qualidade adotado assentava-se em princípios abrangentes que a consideram como conceito relativo e baseado em valores. Esta definição de qualidade é por si só importante, uma vez que, nesse processo, discutem-se valores, ideias, conhecimentos e experiências (MOSS, 2002). A partir dessa premissa, o Ministério da Educação, por meio da SEB e COEDI, apresentam no ano de 2006 o documento Parâmetros de Qualidade para a Educação Infantil, contendo referências de qualidade para a Educação Infantil a serem utilizadas pelos sistemas educacionais, por creches, pré-escolas e centros de Educação Infantil. Estes parâmetros visam a promoção da igualdade de oportunidades educacionais sem perder de vista as diferenças, diversidades e desigualdades do território e das muitas culturas nele presentes. Este documento pretendia contribuir para um processo democrático de implementação das políticas públicas para as crianças de 0 até 5 anos, por meio de uma divulgação e discussão amplas, servindo efetivamente como referência para a organização e o funcionamento dos sistemas de ensino (BRASIL, 2006).

$\mathrm{O}$ documento divide-se em dois volumes. O primeiro traz aspectos conceituais, filosóficos e históricos relevantes para a definição de parâmetros de qualidade para a Educação Infantil no Brasil.

Apresenta uma concepção de criança, de pedagogia da Educação Infantil, a trajetória histórica do debate da qualidade na Educação Infantil, as principais tendências identificadas em pesquisas recentes dentro e fora do país, os desdobramentos previstos na legislação nacional para a área e consensos e polêmicas no campo (Ibidem, p. $10)$.

O segundo volume indica, inicialmente, as competências dos sistemas de ensino, bem como caracteriza as instituições de Educação Infantil a partir de bases legais. Por fim, são apresentados os parâmetros de qualidade para os sistemas educacionais e para as instituições de educação infantil no Brasil, com o intuito de estabelecer uma referência nacional que subsidie a discussão e implementação de parâmetros de qualidade locais (BRASIL, 2006).

A concepção de criança adotada mostra-se alinhada aos debates e discussões que vinham se constituindo no período anterior e também com as DCNEIs, publicadas no ano de 1999. De acordo com o documento (BRASIL, 2006), a criança é um sujeito 
social e histórico que está inserido em uma sociedade na qual partilha de uma determinada cultura. É profundamente marcada pelo meio social em que se desenvolve, mas também contribui com ele (BRASIL, 1994a). A criança, assim, não é uma abstração, mas um ser produtor e produto da história e da cultura (FARIA, 1999).

Em síntese, para propor parâmetros de qualidade para a Educação Infantil, é imprescindível levar em conta que as crianças desde que nascem são:

- cidadãos de direitos;

- indivíduos únicos, singulares;

- seres sociais e históricos;

- seres competentes, produtores de cultura;

- indivíduos humanos, parte da natureza animal, vegetal e mineral. (BRASIL, 2006, p. 18).

No que diz respeito à perspectiva educacional, o documento sustenta que as crianças devem ser apoiadas e incentivadas a

- brincar;

- movimentar-se em espaços amplos e ao ar livre;

- expressar sentimentos e pensamentos;

- desenvolver a imaginação, a curiosidade e a capacidade de expressão;

- ampliar permanentemente conhecimentos a respeito do mundo da natureza e da cultura apoiadas por estratégias pedagógicas apropriadas;

- diversificar atividades, escolhas e companheiros de interação em creches, pré-escolas e centros de Educação Infantil (BRASIL, 2006, p.18).

Observa-se uma concepção de qualidade para a Educação Infantil ampla e assertiva que defende reflexão sobre a qualidade educacional como importante fator na defesa da própria constituição do país. Seguindo essa premissa, o volume 2 apresenta define dentro de marcos legais as competências dos sistemas de ensino com relação à Educação Infantil. Em seguida, apresenta uma breve caracterização das Instituições de Educação Infantil brasileiras. Por fim, apresentam os Parâmetros Nacionais de Qualidade para a Educação Infantil. Tais parâmetros abordam: as propostas pedagógicas; gestão das Instituições, professoras, professores e demais profissionais de Educação Infantil; interações entre professores(as), gestores(as) e demais profissionais e infraestrutura. Cada um dos itens abordados é composto por subitens descritivos que tratam das questões mais específicas dentro de uma temática maior (BRASIL, 2006).

Assim, um desdobramento necessário e esperado do documento que está sendo apresentado seria a definição dos indicadores de qualidade. 
Estes permitirão a criação de instrumentos para credenciamento de instituições, elaboração de diagnósticos, e mesmo a implementação propriamente dita dos parâmetros de qualidade nas instituições de Educação Infantil e nos sistemas educacionais (BRASIL, 2006, p. 8).

Havia, naquele momento, a expectativa de construção de Indicadores Nacionais de Qualidade para a Educação Infantil, o que veio a se concretizar somente no ano de 2009. Estes indicadores traduziam e detalhavam os Parâmetros Nacionais (BRASIL, 2006). Os indicadores são apresentados como

[...] sinais que revelam aspectos de determinada realidade e que podem qualificar algo. Por exemplo, para saber se uma pessoa está doente usamos vários indicadores: febre, dor, desânimo. Para saber se a economia do país vai bem, usamos como indicadores a inflação e a taxa de juros. A variação dos indicadores nos possibilita constatar mudanças (a febre que baixou significa que a pessoa está melhorando; a inflação mais baixa no último ano diz que a economia está melhorando). Aqui, os indicadores apresentam a qualidade da instituição de educação infantil em relação a importantes elementos de sua realidade: as dimensões (Idem, 2009, p.15).

Com o foco na autoavaliação das instituições de Educação Infantil, os indicadores são compostos por 7 dimensões que avaliam: o planejamento institucional; a multiplicidade de experiências e linguagens, interações; promoção da saúde; espaço, materiais e mobiliários; formação e condições de trabalho das professoras e demais profissionais; trocas com as famílias; e participação na rede de proteção social. Dentro dessas 7 dimensões existem indicadores específicos a serem avaliados. A avaliação deve exprimir o consenso alcançado, após discussões em pequenos grupos, em plenárias compostas pela comunidade, famílias e profissionais. A avaliação era feita com o auxílio de cores: verde, amarelo e vermelho para qualificar cada dimensão. Verde para o que está bom; amarelo para o que está caminhando, mas precisa melhorar; e vermelho para o que está ruim. Ao fim do processo, cada unidade define autonomamente formas de encaminhamento das questões levantadas (BRASIL, 2009). Além de propor uma autoavaliação institucional, o documento procura estabelecer no terreno institucional um debate sobre a qualidade, considerando o conceito apresentado por Moss (2002).

Em 2009, o MEC realiza nova pesquisa a fim de mapear e analisar as propostas curriculares e pedagógicas em curso na educação infantil no contexto dos municípios brasileiros, com o propósito de suplementar as discussões a respeito da construção de quaisquer guias curriculares para essa área. A amostra foi composta por propostas 
pedagógicas e curriculares de 48 municípios com diferentes características. Constatouse que a maior parte dos municípios apenas reproduzia o Referencial Curricular Nacional para a Educação Infantil. Para justificar a ausência de propostas, alguns municípios alegaram, entre outras questões, a falta de estrutura e de recursos, o que evidencia, segundo Barbosa (2010), a pequena importância dada à proposta curricular ou pedagógica no contexto das creches e pré-escolas brasileiras. Quanto aos currículos praticados na maior parte dos municípios, o autor ressalta que, embora as propostas anunciem uma concepção curricular mais próxima às teorizações curriculares que emergem na década de 80 , na prática, encontra-se o retorno às matrizes curriculares antigas, centradas muitas vezes no controle social e no calendário de eventos.

Constatou-se também que os bebês de 0 a 3 anos, pouco aparecem nas Propostas Curriculares para a Educação Infantil, sendo citados somente quando se trata de cuidados, proteção, higiene, vínculos familiares e dependência em relação ao adulto (Ibidem, 2010).

Do exposto, conclui-se que, embora as discussões em torno da construção de um currículo no âmbito da educação infantil tenham ganhado mais e mais destaque no âmbito dos debates e documentos legais, as práticas nas creches brasileiras revelam-se distantes das intenções assinaladas nos textos de pesquisas e de orientações legais. Corroboram essa constatação os dados provenientes do mapeamento das propostas pedagógicas e curriculares atualmente vigentes no campo da educação infantil de 0 a 5/6 anos (BRASIL, 1996; 2009).

No que diz respeito particularmente às creches, embora tenhamos avançado nas disposições legais, é necessário ainda um olhar específico para as crianças pequenas de 0 a 3 anos que, segundo Barbosa (2010, p. 8), "negam o oficio de aluno e reivindicam ações educativas voltadas para a intersecção do lúdico com o cognitivo nas diferentes linguagens".

Apontando para a construção de propostas curriculares voltadas à educação Infantil de 0 a 5 anos, a DCNEI é reeditada no ano de 2009, tornando-se o centro das discussões no âmbito da educação das crianças pequenas. Apresentando-se nos seguintes termos legais:

Art. $1^{\circ}$. A presente Resolução institui as Diretrizes Curriculares Nacionais para Educação Infantil a serem observadas na organização de propostas pedagógicas na Educação Infantil. 
Art. $2^{\circ}$. As Diretrizes Curriculares Nacionais para a Educação Infantil articulam-se com as Diretrizes Curriculares Nacionais da Educação Básica e reúnem princípios, fundamentos e procedimentos definidos pela Câmara de Educação Básica do Conselho Nacional de Educação, para orientar as políticas públicas na área e a elaboração, planejamento, execução e avaliação de propostas pedagógicas e curriculares (BRASIL, 2009c).

Entre as treze Diretrizes, é a terceira que apresenta a concepção de currículo adotada. Tal concepção sustenta-se no respeito à criança e à sua identidade cultural, social e étnica. Orientadas nesse sentido, as práticas precisam respeitar as múltiplas identidades, promovendo situações que favoreçam a expressão, o desenvolvimento, a convivência e a aprendizagem, em um ambiente lúdico e prazeroso. Nesses termos, o currículo é concebido

[...] como um conjunto de práticas que buscam articular as experiências e os saberes das crianças com os conhecimentos que fazem parte do patrimônio cultural, artístico, ambiental, científico e tecnológico, de modo a promover o desenvolvimento integral de crianças de 0 a 5 anos de idade (BRASIL, 2009c, art. $3^{\circ}$ ).

Essa percepção sobre o currículo demonstra um conceito mais amplo, que se aproxima dos princípios defendidos por Stenhouse (1991) e Goodson (2007), segundo os quais o currículo é uma construção efetivada por meio das relações sociais entre crianças, professores e demais atores que afetam diretamente a construção de sua identidade (SILVA, 1999).

Vale destacar que, embora a proposta pedagógica e o projeto pedagógico tenham sido utilizados, por muito tempo, como sinônimo de currículo no contexto da educação infantil, nas DCNEI há clara distinção entre esses termos. Desta maneira, entende-se por proposta pedagógica o plano orientador das ações na instituição, definidor das metas que se pretende atingir para promover as aprendizagens e desenvolvimento de meninos e meninas que são educados e cuidados nas creches e pré-escolas (BRASIL, 2009a). Para isso, é necessário que essas propostas tenham como base a concepção de criança formulada na quarta Diretriz.

Art. $4^{\circ}$. As propostas pedagógicas da Educação Infantil deverão considerar que a criança, centro do planejamento curricular, é sujeito histórico e de direitos que, nas interações, relações e práticas cotidianas que vivencia, constrói sua identidade pessoal e coletiva, brinca, imagina, fantasia, deseja, aprende, observa, experimenta, narra, 
questiona e constrói sentidos sobre a natureza e a sociedade, produzindo cultura (BRASIL, 2009c).

É dada à criança a posição central, ou seja, ela está no cerne do planejamento curricular, e isso implica que as suas especificidades não podem deixar de ser consideradas. Nessa perspectiva, Cruz (2013) entende que somente levando em conta a singularidade das crianças é que o planejamento e a avaliação da prática pedagógica ganham sentido e podem ser adequados. Da mesma maneira, o reconhecimento da criança enquanto sujeito histórico que constrói sua identidade por meio das relações e interações que estabelece e das práticas cotidianas que vivencia requer outra forma de pensar as propostas curriculares e as práticas pedagógicas no contexto das creches e préescolas. "A apropriação da concepção de criança ativa, competente, curiosa, questionadora, com desejos, imaginação e fantasias próprios, pode significar uma mudança radical na prática pedagógica, no currículo praticado" (CRUZ, 2013, p.14).

De acordo com as DCNEIs (2009), as propostas pedagógicas nas creches e préescolas brasileiras, devem estar pautadas em três princípios: princípio ético, envolvendo autonomia, responsabilidade, solidariedade e respeito ao bem comum, ao meio ambiente e às diferentes culturas, identidades e singularidades; princípio político, que se refere aos direitos e deveres da cidadania, ao exercício da criticidade e ao respeito à ordem democrática; e princípio estético, que envolve a sensibilidade, a criatividade, a ludicidade e a diversidade de manifestações artísticas e culturais. Tais princípios devem ser considerados para que se defina inicialmente para qual sociedade se está educando e cuidando das crianças de 0 a 5 anos. Para além disso, tais propostas devem ser pensadas de forma a garantir a todas as crianças

[...] [o] acesso a processos de apropriação, renovação e articulação de conhecimentos e aprendizagens de diferentes linguagens, assim como o direito à proteção, à saúde, à liberdade, à confiança, ao respeito, à dignidade, à brincadeira, à convivência e à interação com outras crianças (BRASIL, 2009c, art. $8^{\circ}$ ).

O documento não se limita a enunciar o direito à educação infantil, mas articula os direitos e os princípios da cidadania aos diversos aspectos da educação infantil expressos por meio das práticas cotidianas. Nesse contexto, professoras e professores são atores importantes na (co)construção das aprendizagens. 


\begin{abstract}
Atividades realizadas pela professora ou professor de brincar com a criança, contar-lhe histórias, ou conversar com ela sobre uma infinidade de temas, tanto promovem o desenvolvimento da capacidade infantil de conhecer o mundo e a si mesmo, de sua autoconfiança e a formação de motivos e interesses pessoais, quanto ampliam as possibilidades da professora ou professor de compreender e responder às iniciativas infantis (BRASIL, 2009a, p. 7).
\end{abstract}

Outro fator que merece atenção na realização das propostas pedagógicas diz respeito à não fragmentação da criança. Ela precisa ser vista e considerada em sua integralidade, e, portanto, não pode haver separação entre as diferentes áreas do conhecimento e a vida cidadã. Ou seja, conhecer e aprender somente têm sentido quando articulados às múltiplas dimensões humanas, e isso implica que o educar e o cuidar são aspectos indissociáveis que devem ser planejados intencionalmente na organização da prática cotidiana com as crianças.

\begin{abstract}
As práticas pedagógicas devem ocorrer de modo a não fragmentar a criança nas suas possibilidades de viver experiências, na sua compreensão do mundo feita pela totalidade de seus sentidos, no conhecimento que constrói na relação intrínseca entre razão e emoção, expressão corporal e verbal, experimentação prática e elaboração conceitual. As práticas envolvidas nos atos de alimentar-se, tomar banho, trocar fraldas e controlar os esfíncteres, na escolha do que vestir, na atenção aos riscos de adoecimento mais fácil nessa faixa etária, no âmbito da Educação Infantil, não são apenas práticas que respeitam o direito da criança de ser bem atendida nesses aspectos, como cumprimento do respeito à sua dignidade como pessoa humana. Elas são também práticas que respeitam e atendem ao direito da criança de apropriar-se, por meio de experiências corporais, dos modos estabelecidos culturalmente de alimentação e promoção de saúde, de relação com o próprio corpo e consigo mesma, mediada pelas professoras e professores, que intencionalmente planejam e cuidam da organização dessas práticas (BRASIL, 2009a, p. 9).
\end{abstract}

Para educar de modo integrado com o cuidar as instituições de educação infantil devem oferecer condições para as crianças explorarem o ambiente de diferentes maneiras, para que, assim, meninos e meninas possam construir sua singularidade na relação com o outro. Para isso, cada instituição necessita conhecer a constituição plural das crianças e de suas famílias e reforçar, por meio da gestão democrática, a abertura à comunidade, fomentando sua participação efetiva na elaboração e no acompanhamento curricular. Cada instituição deve "[...] garantir a participação, o diálogo e a escuta cotidiana das famílias, o respeito e a valorização de suas formas de organização [...] [e] o estabelecimento de uma relação efetiva com a comunidade local e de mecanismos que 
garantam a gestão democrática e a consideração dos saberes da comunidade" (BRASIL, 2009c, art. 8, 1, III).

As práticas pedagógicas, de acordo com o artigo $9^{\circ}$ das DCNEI, devem ter como eixos norteadores a brincadeira e as interações. A partir dessa Diretriz, nota-se a importância conferida ao ato de brincar. Entende-se que o brincar, como prática pedagógica, requer certa organização e intencionalidade relativos aos tempos e espaços para a brincadeira (BRASIL, 2009c). Nesse contexto, cabe às professoras e aos professores oferecerem aos meninos e meninas oportunidades de brincar, incorporando estas práticas ao dia a dia de cada instituição. De acordo com Kishimoto (2013), para uma educação de qualidade, a criança precisa tanto de brincadeiras livres nas quais possa tomar a iniciativa, como de daquelas outras orientadas pelas professoras e professores para aprender coisas que não sabe.

Brincadeiras de alta qualidade fazem a diferença para o resto da vida das crianças. A educação da criança de creche e pré-escola se faz por meio do currículo/proposta pedagógica, que inclui brincadeiras e interações, o que requer uma equipe que compartilhe da ideia de que, ao brincar, a criança se expressa, aprende e se desenvolve na companhia de outras crianças, de adultos, de brinquedos e de materiais (KISHIMOTO, 2013, p. 10).

Não obstante o caráter mandatório do texto das DCNEI, fica reconhecida a autonomia das instituições na construção de sua proposta curricular, bem como a singularidade de seus atores e contextos. Nesse sentido, existem princípios gerais que devem ser levados em consideração sem perder de vista as características próprias de cada creche e pré-escola. O texto legal determina que

Art. $9^{\circ}$. [...]

Parágrafo único. As creches e pré-escolas, na elaboração da proposta curricular, de acordo com suas características, identidade institucional, escolhas coletivas e particularidades pedagógicas, estabelecerão modos de integração dessas experiências (BRASIL, 2009c).

Por fim, cabe dizer que as Diretrizes Curriculares Nacionais para a Educação Infantil surgiram como uma proposta curricular cuidadosa, aberta, centrada nas especificidades da criança e no reconhecimento de seus direitos fundamentais (CAMPOS; ROSEMBERG, 2009). 
As palavras de Cruz (2013, p. 17) expressam muito bem as possibilidades abertas pelas DCNEI:

\begin{abstract}
Se o conjunto de práticas que constitui o currículo na Educação Infantil acontecer com esse cuidado que é preconizado, haverá grande possibilidade de esta primeira etapa da educação realmente contribuir para a formação de novas pessoas. Pessoas que, além de se apropriarem "dos conhecimentos que fazem parte do patrimônio cultural, artístico, ambiental, científico e tecnológico", sejam comprometidas "com a ludicidade, a democracia, a sustentabilidade do planeta e com o rompimento de relações de dominação etária, socioeconômica, étnico-racial, de gênero, regional, linguística e religiosa".
\end{abstract}

Em âmbito nacional, revela-se um avanço considerável na preocupação, expressa claramente no âmbito legal, não somente com o atendimento à criança pequena de 0 a 5 anos, mas também com a qualidade desse atendimento, ênfase estabelecida pela política de educação nacional que deve ser eixo norteador para todos os municípios.

\title{
2.3 Creches no sistema educacional paulistano: outro olhar para a educação das crianças pequenas
}

São Paulo, uma das mais importantes cidades do Brasil, destacou-se também nas políticas de creche, de maneira que os principais acontecimentos relacionados às creches brasileiras tiveram início em território paulistano. Os avanços legais, o contexto político e histórico por que passavam essas instituições fizeram do município de São Paulo um dos pioneiros no cumprimento das determinações legais apresentadas no item anterior. A partir do ano de 2001, teve início, no município, o processo de transição das creches para a Secretaria Municipal de Educação (SME), atendendo ao artigo 89 da LDB, o qual determinava que "[...] as creches e pré-escolas existentes ou que venham a ser criadas deverão, no prazo de três anos, a contar da publicação desta Lei, integrar-se ao respectivo sistema de ensino" (BRASIL, 1996).

Por meio do Decreto n ${ }^{\circ} 41.558$, de 28 de dezembro de 2001, a Prefeitura fixou as normas para passagem das creches da Secretaria de Assistência Social para a Secretaria de Educação.

Art. $1^{\circ}$. Os Centros de Educação Infantil - CEIs, da rede direta municipal, com suas atribuições, pessoal, acervo, recursos financeiros e próprios municipais em que se encontram atualmente instalados, 
ficam transferidos da Secretaria Municipal de Assistência Social SAS para a Secretaria Municipal de Educação - SME, integrando a Rede Municipal de Ensino.

Art. $2^{\circ}$. As Secretarias Municipais de Assistência Social e de Educação diligenciarão visando à adoção das providências necessárias às transferências de bens patrimoniais, serviços e competências atinentes aos CEIs.

Art. $3^{\circ}$. As Secretarias Municipais de Gestão Pública, de Finanças e Desenvolvimento Econômico, e de Planejamento Urbano adotarão as medidas necessárias, no âmbito de suas respectivas competências, para o integral cumprimento do disposto neste decreto.

Art. $4^{\circ}$. As despesas decorrentes da execução deste decreto correrão por conta das dotações orçamentárias próprias, suplementadas se necessário.

Art. $5^{\circ}$. Este decreto entrará em vigor em $1^{\circ}$ de janeiro de 2002, revogadas as disposições em contrário (SÃO PAULO, 2001b).

Ainda no ano de 2001, foi publicado o Decreto $n^{\circ} 40.268$, de 31 de janeiro, que dispôs sobre a efetivação de diretrizes para a integração das creches à educação. Em seu artigo $1^{\circ}$, o decreto estabeleceu a faixa etária que deveria ser atendida nessas instituições; nos artigos $3^{\circ}, 4^{\circ}$ e $6^{\circ}$, orientou os encaminhamentos a respeito da creche, entre eles a mudança de nomenclatura:

Art. $1^{\circ}$. As creches municipais da rede direta, da rede indireta e as particulares conveniadas, integradas ao Sistema Municipal de Ensino, poderão atender a crianças de 0 (zero) a 6 (seis) anos e 11 (onze) meses de idade, observando as diretrizes estabelecidas neste decreto. [...] Art. $3^{\circ}$. Os Secretários Municipais de Educação e de Assistência Social constituirão, por meio de portaria intersecretarial, Comissão integrada por representantes de ambas as Pastas, com o objetivo de fixar, em prazo a ser estabelecido no mesmo ato, as normas a serem seguidas pelas creches municipais das redes direta e indireta e as particulares conveniadas.

[...] Art. $4^{\circ}$. A partir de $1^{\circ}$ de julho de 2001, as creches municipais das redes direta e indireta passam a denominar- se Centros de Educação Infantil - CEI, mantido o cumprimento do disposto no parágrafo único do art. $1^{\circ}$ deste decreto.

[...]Art. $6^{\circ}$. As despesas decorrentes da execução deste decreto correrão por conta de dotações orçamentárias próprias, suplementadas se necessário (SÃO PAULO, 2001a).

As creches, atuais Centros de Educação Infantil, sofreram não somente uma mudança na nomenclatura. Houve também mudança de concepções, acompanhada de um novo olhar para essas instituições, o qual envolvia, entre outras, as questões curriculares. Foram apresentadas algumas reflexões a respeito de uma pedagogia da 
infância e outros referenciais que visavam subsidiar o trabalho pedagógico no interior das creches/CEIs.

Como resultado dessas reflexões, a Secretaria Municipal de Educação editou, no ano de 2004, o Caderno Temático 2. Educação Infantil: Construindo a Pedagogia da Infância no Município de São Paulo. O objetivo maior da publicação era fomentar e ampliar as reflexões em torno da temática da cultura da infância, reafirmando uma concepção de currículo que considera a leitura de mundo, o letramento e a diversidade cultural, de gênero, sexual e étnico-racial. Com os textos apresentados neste Caderno, pretendia-se provocar uma discussão com a comunidade educativa sobre a prática pedagógica desenvolvida nas Unidades Educacionais CEI e EMEI, procurando trazer à tona questões que ajudassem os(as) educadores(as) a refletir sobre os seus fazeres cotidianos (SÃO PAULO, 2004b).

Os textos contidos no Caderno Temático 2 representam produções de um grupo de palestrantes que participaram de um evento que reuniu, na ocasião, as Equipes Pedagógicas das Subprefeituras Municipais. Todos os textos almejavam ampliar as discussões acerca da Pedagogia da Infância.

Essa Pedagogia implica em considerar, a criança, desde o nascimento como produtora de conhecimento e cultura, a partir das múltiplas interações sociais e das relações que estabelece com o mundo, influenciando e sendo influenciada por ele, construindo significados a partir dele. Consideramos que a Educação Infantil se faz por diversos atores: os(as) educadores(as), as crianças e suas famílias e toda a Comunidade Educativa. Porém, o protagonista principal é a criança. Assim nosso mote é como dar voz a esse protagonista, a criança de 0 a e 6anos de idade (SÃO PAULO, 2004b, p.4).

Sob esse enfoque, intentava-se instituir na rede municipal de São Paulo um novo olhar para a infância e para as práticas institucionais. Os textos produzidos por Ana Beatriz Cerisara, Maria Letícia Nascimento, Heloísa Helena Pimenta Rocha, Ana Angélica Albano, Isabel Marques, Ana Beatriz Goulart de Faria e Suely Amaral Mello deveriam ser amplamente discutidos nas unidades, em horários coletivos, em reuniões pedagógicas e reuniões de pais envolvendo toda a comunidade educativa.

O primeiro texto, intitulado "Por uma Pedagogia da Educação Infantil: desafios e perspectivas para professoras", de autoria de Ana Beatriz Cerisara (2004), procura resgatar a história das creches e pré-escolas no Brasil, destacando a forma como essas instituições se constituíram com perspectivas hierarquizadas que separavam assistência 
e educação. Em seguida, expõe a perspectiva de integração entre educação e cuidado, além de abordar a formação das professoras de creche e as questões referentes a uma educação infantil que não seja mera antecipação do ensino fundamental. Por fim, o texto demonstra preocupação com a formação daqueles e daquelas que atuam em creches e pré-escolas, ao relacionar tal formação com os documentos oficiais produzidos desde a década de 1990. Sobre o trabalho pedagógico no CEI, a autora escreve:

Para efeito de reflexão, é possível dizer que há um embate entre dois modelos pedagógicos para o trabalho nos CEIs: o primeiro, que denominamos de concepção de educação assistencial, que nega qualquer intencionalidade educativa, e o segundo, que considera educacional apenas o modelo de escolarização do Ensino Fundamental. Este último acaba sendo visto como a única forma de as instituições de Educação Infantil estarem vinculadas à Educação. Nessa disputa entre isto ou aquilo, está oculta uma outra concepção: educativa, sim, mas não escolar. Ou seja, uma concepção que entende que a Educação Infantil tem uma intencionalidade educativa diferente das escolas de Ensino Fundamental, tal como elas se configuram atualmente (CERISARA, 2004, p.8).

Em “Contextos de Educação da Infância: parceria entre famílias e as instituições de Educação Infantil”, Maria Letícia Nascimento (2004) analisa a educação infantil por seu papel de socialização, contrapondo-se à concepção tradicional de socialização em que a criança aparece como elemento passivo no mundo cultural dos adultos. A autora apresenta uma nova concepção, com fundamentos na Sociologia da Infância:

A partir dessa perspectiva, o processo de socialização deixa de ser uma questão de adaptação e internalização de valores, crenças e normas, para tornar-se apropriação, reinvenção e reprodução da cultura, realizada por meio da atividade em comum na qual as crianças negociam partilham e criam culturas com adultos e com outras crianças (NASCIMENTO, 2004, p.16).

Para Mello (2004), a educação infantil em creches e pré-escolas precisa proporcionar o mergulho na cultura, entendendo que, quanto maior e mais diversificado for o acesso da criança à cultura, mais alto o nível de formação da sua inteligência e personalidade. No entender da autora, a educação infantil em espaços coletivos apresenta inúmeras possibilidades de crescimento das crianças pequenas, em uma perspectiva em que a criança se apresenta sob um novo conceito. Nas palavras de Mello (2004, p. 71): 
Este novo conceito de criança que construímos a partir da observação das crianças - num ambiente em que elas tenham múltiplas possibilidades de atividades - aponta que, diferentemente do que pensávamos até pouco tempo atrás, a criança não é um ser incapaz, frágil, carente e que necessita do adulto o tempo todo para dirigir sua atividade e para garantir proteção. Ao contrário, ela é, desde muito pequena, curiosa, capaz de explorar os espaços e os objetos que encontra ao seu redor, de estabelecer relações com as pessoas, de elaborar explicações sobre os fatos e fenômenos que vivencia.

A educação infantil, incluída a de 0 a 3 anos, é compreendida, no Caderno Temático 2, em sua função social, construída a partir de uma visão de infância enquanto categoria, grupo específico que produz e reproduz a vida social e que, sendo assim, não pode ser pensada independentemente de sexo, etnia e classe social (CERISARA, 2004; NASCIMENTO, 2004).

Ademais, a concepção de criança diferencia-se daquela apresentada no contexto da escolarização. Nesse sentido, a constituição da criança em um determinado contexto sociocultural é vista a partir de uma perspectiva dialética. Propõe-se a superação de certo ideal de infância, a fim de dirigir para as crianças um olhar atento e problematizador, para, a partir daí, construir novas práticas pedagógicas (SÃO PAULO, 2004b).

É possível notar que há, nessa publicação, uma provocação que intenta desencadear um processo reflexivo no interior das instituições, objetivando superar o ideal de infância e desenvolvendo, assim, outro olhar, atento às especificidades da vida das crianças que frequentam as creches e pré-escolas paulistanas.

As concepções sustentadas no Caderno Temático 2 foram reiteradas por meio da Orientação Normativa $n^{\circ}$ 01/2004 - Construindo um Regimento para a Infância, que tinha como propósito subsidiar a construção dos regimentos internos nas unidades educacionais de educação infantil da cidade de São Paulo. Esta Orientação Normativa trouxe, inicialmente, as concepções de educação infantil, infância e criança, aprendizagem, currículo e unidades de educação infantil, considerando a educação como possibilidade do exercício da liberdade que se constitui em instrumento da constituição humana, e não mera reprodução mecânica (SÃO PAULO, 2004c). Nos termos do documento,

[...] as práticas educativas devem propiciar o desenvolvimento da identidade individual e coletiva visando à autonomia da criança, valorizando suas vivências, o diálogo e a participação democrática. 
Devem incentivar a curiosidade, de forma a instigar a criatividade e a reflexão crítica pessoal e social, tendo o prazer como aspecto fundamental nas organizações e construções subjetivas (SÃO PAULO, 2004c, p. 2).

Nessa perspectiva, a criança é compreendida como alguém que, desde o nascimento, produz conhecimento e cultura a partir das múltiplas interações sociais e das relações que estabelece com o mundo, influenciando e sendo influenciada por ele, e assim construindo significados (SÃO PAULO, 2004c). Em consonância com essa visão de criança e educação da infância, a Orientação apresenta a seguinte concepção de currículo:

\begin{abstract}
O currículo, entendido como o conjunto de relações que se estabelece na unidade, construído, portanto, de forma dinâmica e flexível, fundamentado no diálogo e numa perspectiva crítica e coletiva tem, necessariamente, como ponto de partida, os interesses e demandas das crianças e comunidade. Deve levar em conta todas as ações, experiências e vivências em que são envolvidos os sujeitos de sua construção, considerando: sua linguagem, a dimensão lúdica, o tempo e o espaço em que se desenvolvem as atividades, os participantes (atores e protagonistas), as formas de possibilitar as interações e as modalidades de gestão (SÃO PAULO, 2004c, p. 4).
\end{abstract}

O desenvolvimento desse currículo exige que as unidades educacionais se constituam em espaços coletivos de vivência da infância de 0 a 5 anos, que contribuam para a constituição da identidade social e cultural das crianças, fortalecendo a integração entre educar e cuidar (SÃO PAULO, 2004c).

Em uma ação complementar a da família, concebendo a criança enquanto um sujeito de direitos, as unidades de educação infantil não objetivam a antecipação ou preparação para o ensino fundamental, nem tampouco a compensação de carências, mas, sobretudo, constituise como um espaço coletivo de relações múltiplas entre crianças e adultos, através das quais é possível ampliar experiências, enfrentar desafios, fomentar a criatividade, a cooperação, a solidariedade, a autonomia e a cidadania, oportunizando a voz e a vez das crianças, desde as mais pequeninas (SÃO PAULO, 2004c, p. 4).

A prática de educação infantil aqui anunciada concebe a aprendizagem como um processo que articula dois importantes componentes: a interação com as pessoas e a cultura, apresentando, desse modo, uma clara incorporação do referencial históricocultural. Nesse diapasão, o papel do(a) professor(a) é uma preocupação da Orientação Normativa $\mathrm{n}^{\mathrm{o}}$ 01/2004, que dedica um tópico específico ao perfil dos(as) 
professores(as), reconhecendo todos os profissionais da unidade de educação infantil como educadores, uma vez que contribuem para o crescimento das crianças, educando e cuidando, além de ressaltar a importância da relação dos adultos com as crianças, considerada como fundamental para a construção de conhecimento.

\begin{abstract}
Nesse sentido, o(a) educador(a) da infância deve ter um papel fundamental como "observador participativo" que constantemente intervém para oferecer, em cada circunstância, os recursos necessários à atividade infantil, de forma a desafiar adequadamente, promover interações, despertar a curiosidade, (problematizar) mediar conflitos, garantir realizações significativas e promover acesso à cultura possibilitando que as crianças expressem a cultura infantil (SÃO PAULO, 2004c, p. 7).
\end{abstract}

$\mathrm{O}$ (a) professor (a) é apresentado como (co)construtor do currículo, ator que, considerando as crianças enquanto seres sociais, deve lhes proporcionar experiências construídas de forma dialógica. Nesse sentido, o trabalho pedagógico, na concepção dessa Orientação Normativa, é planejado e construído pelas professoras e professores por meio da organização do tempo e do espaço, da seleção de materiais, da organização e do acompanhamento das interações entre as crianças e entre elas e os adultos, tendo a brincadeira como eixo principal (SÃO PAULO, 2004c).

Do exposto, conclui-se que os dois documentos apresentados estão pautados em formulações que se referenciam na Antropologia, na Psicologia e, especialmente, na Sociologia da Infância, trazendo uma concepção sociocultural para pensar a sociedade, as crianças, a infância e as professoras e professores de educação infantil. Ao atribuir às unidades a responsabilidade de elaborar suas propostas pedagógicas de forma autônoma, considerando a cultura e a interação como eixos do processo educativo, rompem com as concepções escolarizadas do currículo, incentivando a construção, dentro de cada unidade, de uma Pedagogia da Infância.

Nos anos de 2006 e 2007, foram publicados dois documentos que deveriam servir de referência para o trabalho pedagógico nas creches e pré-escolas da cidade, sendo eles: Tempos e espaços para a infância e suas linguagens nos CEIs, creches e EMEIs da cidade de São Paulo (SÃO PAULO, 2006a), e Orientações Curriculares: Expectativas de Aprendizagem e Orientações Didáticas para a Educação Infantil (SÃO PAULO, 2007).

Com a publicação do documento Tempos e espaços para a infância e suas linguagens nos CEIs, creches e EMEIs da cidade de São Paulo, procurou-se criar a 
identidade de um todo, de uma rede, e, ao mesmo tempo, chamar a atenção para as características e particularidades de cada contexto. As concepções enunciadas colocam como função da educação infantil a mediação do desenvolvimento sociocultural das crianças pequenas desde o nascimento, por meio da integração do educar e cuidar (SÃO PAULO, 2006a). Logo na introdução, o texto apresenta um olhar para o desenvolvimento infantil que salienta a relação que a criança estabelece com o mundo:

Em sua relação com este mundo, formado pelos costumes, linguagens, valores, relações humanas e por técnicas, as crianças, desde cedo tentam apreendê-lo e significá-lo, mediadas, direta ou indiretamente, por parceiros mais experientes como, por exemplo, o professor, que lhes assegura uma gradativa apropriação da cultura historicamente constituída. Essa experiência é essencial para que a criança também possa ser produtora de cultura, manifestando-se por diferentes linguagens (SÃO PAULO, 2006a, p. 12).

Ao longo do texto, são apresentados temas para debate entre professoras e professores no contexto das unidades educacionais; entre eles, a interação entre educar e cuidar, a organização dos tempos, espaços e materiais, além da relação entre infância, cultura, brincadeira e as diferentes linguagens. Cada temática é abordada de forma a demonstrar que concepções diferentes remetem a práticas também diferentes. Nesse sentido, a concepção que orienta essa publicação renega modelos escolarizantes para o contexto da educação das crianças de 0 a 5 anos. Dessa maneira, considera que

As crianças se apropriam do patrimônio cultural de seu grupo social e têm acesso a itens significativos da produção histórica e cultural da humanidade, à medida que o professor garanta no cotidiano do CEI, da Creche e da EMEI que elas vivenciem diferentes situações nas quais tenham constante oportunidade de escolha, exercitem sua autonomia e conheçam as próprias necessidades, preferências e desejos ligados à construção do conhecimento e do relacionamento interpessoal (SÃO PAULO, 2006a, p. 27).

Assim, cabe às professoras e aos professores organizarem espaços e ambientes que permitam as interações entre crianças e adultos, cumprindo o papel de mediadores das aprendizagens infantis desde a mais tenra idade. Propõe-se uma concepção de currículo que se constrói a partir da escuta de meninos e meninas sobre o que é vivido e narrado no terreno de cada instituição de educação infantil. 
Planejar o currículo vivido na Educação Infantil - que se faz ouvindo as crianças (com seus saberes e motivos, aqui incluindo também os bebês que são "ouvidos" de modo próprio) e também os pais envolve prever condições para a ocorrência de situações de exploração que ofereçam à criança condições para que ela se construa como sujeito que se emociona, pensa, imagina, fabrica coisas. Tais situações podem envolver momentos coletivos em que todas as crianças participem da mesma vivência, momentos de trabalho diversificado realizado por grupos que as elegem segundo seus motivos e condições pessoais, e também momentos em que a privacidade de cada criança seja garantida e ela possa apenas relaxar, ou imaginar, ou explorar o entorno (SÃO PAULO, 2006a, p. 32).

Explicita-se, nessa publicação, a ideia de que as experiências infantis são compostas por diferentes linguagens, mas a brincadeira merece ênfase, na medida em que ela entendida como uma linguagem própria da infância. Ao final do documento, é apresentado o texto "Como as diferentes linguagens podem ser trabalhadas na educação infantil?", no qual são colocados os seguintes tópicos: comunicação e expressão gestual, comunicação verbal, apropriação da leitura e da escrita, criação plástica e visual, dança e música. Esse texto oferece orientações práticas para que o(a) professor(a) organize os tempos, espaços e materiais de forma a favorecer as interações entre adultos e crianças (SÃO PAULO, 2006a).

Embora sustentado em concepções que consideram professoras e professores capazes e responsáveis por pensar em boas situações de aprendizagem e interações para as crianças, o documento demonstra certa incoerência, quando elabora, ao final, uma espécie de manual para realização das práticas, baseando-se em uma racionalidade técnica que desconsidera professoras e professores como protagonistas no processo educativo.

Um ano após publicar esse documento, a Secretaria Municipal de Educação de São Paulo, por meio da Portaria $n^{\circ} 4.507 / 2007$, instituiu o programa Orientações Curriculares: Expectativas de Aprendizagem e Orientações Didáticas para a Educação Infantil. A publicação retoma, em sua introdução, a trajetória histórica da educação infantil na cidade de São Paulo, com ênfase no processo de integração das creches à Secretaria Municipal de Educação, fazendo referências tanto às DCNEI como ao RCNEI. Embora se baseando em documentos de abrangência nacional, esclarece seus próprios objetivos:

Subsidiar cada professor na estruturação de um programa de atividades para as crianças de sua turma apoiar cada equipe no 
planejamento, desenvolvimento e avaliação de seu projeto pedagógico, instrumento que define os conteúdos e as aprendizagens que eles buscam mediar com suas crianças; intensificar a articulação dos CEIs, creches, EMEIs e EMEEs, hoje integrados na rede municipal de ensino, em torno de diretrizes comuns e de um conjunto de aprendizagens que podem ser promovidas com cada grupo de crianças, de modo a dar continuidade às experiências das crianças em seu processo educacional; criar um recurso de comunicação que informe as famílias das crianças matriculadas nas instituições de educação infantil da rede municipal de ensino sobre as perspectivas de trabalho pedagógico que estão sendo discutidas nas unidades (SÃO PAULO, 2007, p. 9).

O texto revela uma concepção de criança como sujeito social, ativo na sociedade e em seu próprio processo de aprendizagem:

Nascida em uma cultura historicamente constituída, a criança é um ser simbólico e de linguagem. Sua experiência nessa e em outras culturas vai lhe exigir e possibilitar a apropriação de múltiplos signos criados pelos homens para dar sentido a suas relações com o mundo da natureza e o da cultura, que incluem o mundo da técnica, da ciência, da política e das artes, dentre outras áreas de produção humana, e a si mesma. Isso coloca a questão da aprendizagem no centro das preocupações dos educadores (SÃO PAULO, 2007, p. 17).

Sob esse ângulo, a aprendizagem é apresentada como experiência realizada por meio da interação com diferentes parceiros e com os artefatos culturais, o que supõe uma percepção de educação e cuidado ampla e indissociável, apresentada nos seguintes termos:

Cuidar inclui acolher, garantir a segurança e alimentar a curiosidade e expressividade infantis. Nesse sentido, cuidar é educar, dar condições para as crianças explorarem o ambiente e construírem sentidos pessoais, à medida que vão se constituindo como sujeitos e se apropriando de modo único das formas culturais de agir, sentir e pensar. Inclui ter sensibilidade e delicadeza, sempre que necessário, além de cuidados especiais conforme as necessidades de cada criança. Portanto, cuidar e educar são dimensões indissociáveis de todas as ações do educador (SÃO PAULO, 2007, p. 20).

O documento reconhece o importante papel das professoras e professores para que a criança aprenda e se familiarize com as significações historicamente elaboradas que irão orientar sua forma de agir, sentir e conhecer o mundo no qual está imersa. Desse modo, o(a) professor(a) age de forma direta e indireta. 
Ele age de uma forma indireta, pelo arranjo do contexto de aprendizagem das crianças: os espaços, os objetos, os horários, os agrupamentos infantis. O professor atua de modo direto conforme interage com as crianças e lhes apresenta modelos, responde ao que elas perguntam, faz perguntas para conhecer suas respostas, as pega no colo quando se emocionam e, por vezes, opõe-se ao que elas estabelecem para ajudá-las a ampliar seu olhar, ensinar as regras sociais de seu grupo social ou aperfeiçoar seu modo de sentir as situações (SÃO PAULO, 2007, p.23).

Apesar de creditar às unidades educacionais e aos seus(as) profissionais a autonomia para promover um trabalho voltado à criança real em contexto real, as Orientações Curriculares destacam uma série de diretrizes de aprendizagem consideradas necessárias para articular o trabalho pedagógico nas unidades, indicando um rol de experiências estruturadas da seguinte maneira:

a) Experiências voltadas ao conhecimento e cuidado de si, do outro, do ambiente;

b) Experiências de brincar e imaginar;

c) Experiências de exploração da linguagem corporal;

d) Experiências de exploração da linguagem verbal;

e) Experiências de exploração da natureza e da cultura;

f) Experiências de apropriação do conhecimento matemático; e

g) Experiências com a expressividade das linguagens artísticas.

Nesse aspecto, as Orientações Curriculares seguem os mesmos padrões do RCNEI, que utiliza a expressão "âmbitos de experiência" para formalizar sua composição curricular. Dessa forma, são dois documentos organizados por uma ótica fragmentada sobre a criança, calcada em um currículo formal estruturado por áreas de conhecimentos e orientados por aspirações escolarizantes. Ademais, as Orientações Curriculares apresentam-se de forma híbrida, ao trazer, em seus enunciados, concepções de criança e de educação diferentes da estrutura proposta como referência para a prática pedagógica docente. Assim, ao mesmo tempo em que professoras e professores são compreendidos como mediadores da aprendizagem infantil, destaca-se um leque de tarefas que eles(as) necessitam colocar em prática para que as aprendizagens ocorram. Os docentes assumem o papel de meros executores, o que assemelha tais Orientações com uma espécie de manual que privilegia, na rotina diária, ora situações de ensino estruturadas pelos adultos em diferentes modalidades didáticas, ora situações não estruturadas em que as crianças possam fazer escolhas. 
Percebe-se que o documento, na prática, apresenta uma concepção de currículo tradicional, fragmentada, centrada no adulto e no controle da aprendizagem da criança, minimizando, assim, o protagonismo infantil.

Destaca-se, que, no ano de 2013, iniciou-se, no município, um processo de discussão para instituição de novas diretrizes curriculares, dentro do Programa Mais Educação São Paulo para a Educação Infantil (SÃO PAULO, 2013). A intenção é construir um currículo integrado voltado à educação infantil e nãos iniciais do ensino fundamental. A proposta apresentada para o currículo da educação básica paulistana é a de integração entre as áreas de conhecimento e as diferentes linguagens, proporcionando uma educação humanizadora das crianças que frequentam as Unidades Educacionais do município de São Paulo (Ibidem). Na educação infantil e anos iniciais do ensino fundamental, especificamente, a proposta de reorganização curricular está pautada nas Diretrizes Curriculares Nacionais para a Educação Infantil e na construção da Pedagogia da Infância, voltada, portanto, aos interesses e demandas da comunidade, à formação contínua dos educadores e aos recursos materiais que qualifiquem os tempos e espaços para a infância e vivências prazerosas e significativas. Desta perspectiva, entende-se que o currículo se constitui a partir das relações e interações que as crianças estabelecem com outras crianças e com os adultos, de maneira que, respeitando a cultura infantil, as práticas pedagógicas devem ter como eixo norteador as interações e a brincadeira.

A proposta vem sendo discutida através do portal Mais educação ${ }^{10}$, e também por consultas públicas realizadas em cada região da cidade. A intenção é estabelecer, a partir de algumas proposições iniciais, um debate que garanta a participação tanto dos(as) profissionais da educação, como das famílias e da sociedade civil (Ibidem). O Programa Mais Educação São Paulo para a Educação Infantil envolve entre outros aspectos a construção de um currículo integrado na primeira infância.

É importante que uma proposta político-pedagógica integradora para a primeira infância seja efetivada por meio de um currículo que considere as crianças de zero a cinco anos e onze meses, independente de serem atendidas em Unidades Educacionais distintas, com o compromisso de garantir às crianças o direito de viver situações acolhedoras, seguras, agradáveis, desafiadoras, que lhes possibilitem apropriar-se de diferentes linguagens e saberes que circulam na sociedade (Ibidem, p. 4).

\footnotetext{
${ }^{10}$ Portal on-line da Secretaria Municipal de Educação do Município de São Paulo.
} 
Pensando em um currículo integrador, o município se propõe a romper a cisão entre creches e pré-escolas e desta com o ensino fundamental. De acordo com declarações dadas no site da Secretaria Municipal de Educação pela atual Diretora de Orientação Técnica da Educação Infantil, Sônia Larrubia Valverde, essa proposta se assenta na concepção de que a criança, desde pequena, é um ser capaz, pensante, que estabelece relações, se manifesta, tem ideias e, ademais, que a infância não termina nem aos 3 nem aos 5 anos .

O currículo Integrador na Educação Infantil municipal será construído levando em consideração os conhecimentos hoje disponíveis sobre a Educação Infantil e as experiências desenvolvidas pelos profissionais da Rede Municipal de Ensino, atualizando orientações vigentes e trazendo novos elementos capazes de orientar o trabalho com as crianças nas diferentes etapas de seu desenvolvimento (SÃO PAULO, 2013, p. 4).

Outra preocupação que se coloca atualmente na cidade diz respeito à avaliação na Educação Infantil, objeto da Orientação Normativa $n^{\circ} 01$ de 2013, que traz como título: “Avaliação na Educação Infantil: aprimorando os olhares”. O documento aborda discussões em âmbito municipal envolvendo vários aspectos: bases legais, concepção de educação infantil, criança, currículo, perfil do educador, participação das famílias, projeto pedagógico e, por fim, uma discussão mais aprofundada sobre a avaliação no contexto da Educação Infantil. O propósito da orientação normativa se apresenta nos seguintes termos

[...] a Secretaria Municipal de Educação constitui Grupo de Trabalho, que possui representatividade de todas as regiões da cidade, por meio da Portaria SME no 5.076, de 02/09/13, objetivando a elaboração da presente Orientação Normativa, visando definir procedimentos comuns para que as Unidades Educacionais de Educação Infantil realizem a avaliação do desenvolvimento das crianças e sintetizem esse processo em documentação específica que permita verificar a sua trajetória educacional nessa etapa de educação (SÃO PAULO, 2013b, p. 3).

O documento ainda discute e propõe a avaliação não comparativa, ou seja, da criança em relação a si mesma, como instrumento adequado para registrar as experiências por elas vivenciadas diariamente, suas descobertas e aprendizagens. O objetivo seria identificar, neste processo contínuo, interesses, potencialidades e necessidades de meninos e meninas da Educação Infantil (SÃO PAULO, 2013b). 
Nesse contexto, o conceito de documentação pedagógica aparece como importante aliado, justamente porque, pontuada no momento histórico vivido, desvela a concepção subjacente ao trabalho pedagógico, fazendo com que as várias vozes dos atores e protagonistas (meninos e meninas, professores(as) e famílias) sejam ouvidas, dando visibilidade aos múltiplos saberes vividos na Unidade Educacional (Ibidem).

O documento traz ainda algumas questões que podem nortear o olhar da professora no momento da elaboração da documentação.

- Quais os interesses dos bebês e das crianças?

- Que tipos de teorias meninos e meninas elaboram?

- Como posso instigar/desafiar essas teorias?

- Como propiciar que os bebês e as crianças possam ampliar suas experiências com as diferentes temáticas e linguagens garantindo situações significativas de construção de conhecimento, superando atividades desconexas e apartadas?

- Como os bebês e as crianças constroem as suas culturas de pares e com os adultos?

- Como os bebês demonstram na relação entre si e com os adultos suas preferências e os seus sentimentos?

- O que as crianças e suas famílias pensam sobre a Educação Infantil? (Ibidem, p. 13).

Para além da avaliação da criança, discute-se também a avaliação institucional. O documento apresenta a avaliação institucional em uma perspectiva formativa, como um processo em que as famílias, docentes, gestores e demais funcionários da unidade, refletindo sobre os dados referentes à instituição, podem avaliá-la e reconhecendo suas conquistas, avanços e retrocessos.

Assim, a avaliação institucional pode ser instrumento potente para reconstrução das práticas, resultantes do confronto e da negociação de posições, de interesses, de perspectivas; e ainda, para o fortalecimento das relações internas, bem como das demais instâncias decisórias da Rede de Ensino (Ibidem, p.15).

Partindo dessa premissa, a Secretaria Municipal de Educação tem incentivado as unidade Educacionais de Educação Infantil a fazer uso dos Indicadores de Qualidade para a Educação Infantil (BRASIL, 2009). Essas experiências com o uso dos indicadores têm sido compartilhadas pelas unidades em seminários regionais. A ideia é construir um documento de autoavaliação institucional com a participação de alguns representantes das unidades em âmbito municipal, o que mais tarde deverá ser utilizado obrigatoriamente por todas as instituições de educação infantil paulistanas. Atualmente, 
tanto os Indicadores de Qualidade do município como o documento do currículo integrador vem sendo foco de debates para sua construção e futura publicação.

Nesse momento histórico, o município realiza um movimento que procura estabelecer uma política de educação infantil integradora, que reconheça as especificidades das crianças que frequentam essas instituições e das profissionais que nelas atuam, o que se revela no excerto abaixo.

Considerando a especificidade da Educação Infantil e a singularidade dos bebês e crianças pequenas, meninas e meninos, a docência nesta etapa da educação básica se constitui como um ofício em construção, com saberes singulares, sobretudo, marcados pelo fato da Educação Infantil ser um espaço educacional e não escolar com formas específicas de ser professor, de elaborar o planejamento, os registros e a avaliação, de realizar a gestão dos tempos e materiais a fim de que as crianças tenham tempo para construir os seus projetos e teorias, relações, etc. (SÃO PAULO, 2013b, p. 7).

\subsection{Profissionais de Creche/CEI: breve histórico da profissão e circunstâncias atuais}

O processo de expansão das creches diretas na cidade de São Paulo durante a década de 70 e 80 acarretou algumas mudanças na configuração do quadro de profissionais que atuavam nessas instituições. Houve a criação de novos cargos, como o de pajem, o de auxiliar de desenvolvimento infantil (ADIs) e o de professore(a). As pajens deveriam cumprir uma jornada de 40 horas e ter estudado até a $4^{\mathrm{a}}$ série; das ADIs era exigido o $1^{\circ}$ grau completo, com uma jornada de trabalho de 40 horas semanais; já os(as) professores(as) deveriam ter cursado o $2^{\circ}$ grau completo e cumprir jornada de 20 horas semanais (ROSEMBERG; CAMPOS; HADDAD, 1991). A prática de contratação para esses cargos por meio de concurso público somente ganhou corpo a partir de 1989, quando as creches municipais passaram a ser definidas nos seguintes termos:

Um equipamento social que, neste contexto histórico, político e econômico, cumpre o duplo papel de proporcionar educação, guarda e alimentação da criança e de liberar a mãe (ou pai) para a inserção no mercado de trabalho, e para um conjunto de práticas sociais, culturais, políticas, de lazer (e de preguiça), de modo a estabelecer uma relação mais rica entre o mundo social e público, sob a perspectiva do alargamento da cidadania (SÃO PAULO, 1989, p. 12). 
A partir de então, começou-se a investir mais em formação continuada dos profissionais, revelando uma preocupação maior em relação à proposta políticopedagógica para as creches. Havia, paralelamente, uma discussão envolvendo o educar e o cuidar. Foram realizados os primeiros concursos para os cargos de ADI, pedagogo, entre outros.

No ano de 1997, momento em que as creches estavam sob a responsabilidade da Secretaria de Assistência Social (SAS), para ingressar na Prefeitura Municipal de São Paulo no cargo de ADI, era necessário ter formação em nível médio, ou seja, o $2^{\circ}$ grau completo.

No período entre 1997 a 2001, houve muitos avanços no que diz respeito à organização das creches, considerando desde o espaço físico até a formação dos profissionais, no entanto, essas instituições permaneciam ligadas à Secretaria de Assistência Social (CREPALDI, 2002). É somente em 2001 que as creches são integradas ao sistema educativo. Neste novo contexto, ocorreu uma reorganização do quadro de funcionários, por meio de uma alteração promovida pela Lei ${ }^{\circ} 13.574 / 2003$, que passou a conter a seguinte determinação, em seu artigo 10:

Art. 10. Os cargos de Auxiliar de Desenvolvimento Infantil, de Pedagogo e de Diretor de Equipamento Social do Quadro dos Profissionais da promoção Social, titularizados por servidores lotados nos Centros de Educação Infantil da rede direta, que foram transferidosda Secretaria Municipal de Assistência Social para a Secretaria Municipal de Educação por meio do Decreto $n^{\circ} 41.588$, de 28 de dezembro de 2001, serão transformados, nos termos desta lei, em cargos de Professor de Desenvolvimento Infantil, Coordenador Pedagógico e de Diretor de Escola, respectivamente, à medida que seus titulares comprovem possuir a habilitação exigida e $\mathrm{o}$ preenchimento das exigências específicas para o provimento desses cargos (SÃO PAULO, 2003).

No que se refere ao processo de formação dos profissionais do CEI durante e após a transição, as descrições de Pinazza (2013a, p. 220) são bastante esclarecedoras:

Esses acontecimentos determinaram a busca pela adequação dos quadros de profissionais atuantes no que tange a formação mínima exigida, conforme as determinações legais vigentes em âmbito nacional, a partir da Lei de Diretrizes e Bases da educação nacional, LDBN, $n^{\circ}$ 9394/96. Junto com investimentos de formação inicial, como os programas ADI - Magistério (2004) e PEC - Município (2003-2004 e 2006-2007), eram necessários programas de formação contínua em serviço para dar conta de um contingente expressivo de profissionais de Educação Infantil, em especial dos CEIs, que, a 
despeito de terem o certificado exigido, não possuíam formação específica para a atuação com crianças pequenas e pouco conheciam a realidade de educação Infantil.

A passagem das creches para a secretaria de educação, na cidade de São Paulo, desencadeou inúmeras iniciativas por parte do Poder Público, a fim de adequar esses equipamentos às novas demandas. Era necessário reestruturar a carreira das profissionais, a formação, as propostas pedagógicas etc. As mudanças relativas ao perfil profissional exigido para o trabalho nessas instituições foram significativas. $\mathrm{O}$ município passou a adotar uma série de ações para atender às determinações previstas por lei e buscou, por meio dos programas PEC-Município e ADI-Magistério, proporcionar aos profissionais que já atuavam na creche a formação mínima estabelecida por lei (PINAZZA, 2013b).

No ano de 2003, por meio da Lei $\mathrm{n}^{\mathrm{o}}$ 13.574, de 12 de maio, os cargos de Auxiliar de Desenvolvimento Infantil (ADI) foram ganharam um novo estatuto: Professor de Desenvolvimento Infantil (PDI). De acordo com a referida lei:

Art. $2^{\circ}$. Ficam transformados 4000 (quatro mil) cargos vagos de Auxiliar de Desenvolvimento Infantil, do Quadro dos Profissionais da Promoção Social, organizado pela Lei $n^{\circ} 11.633$, de 1994, e Professor de Desenvolvimento Infantil, na conformidade do Anexo I, desta lei, que passam a integrar o Anexo I - Tabela B, da Lei $\mathrm{n}^{\circ} 11.434$, de 1993.

Parágrafo único. Os cargos ora transformados passam a integrar a Classe II, da carreira do Magistério Municipal, do Quadro dos Profissionais de Educação.

Art. $3^{\circ}$. O desempenho das atribuições dos titulares dos cargos de Professor de Desenvolvimento Infantil dar-se-á exclusivamente nos Centros de Educação Infantil, da Secretaria Municipal de Educação.

Art. $4^{\circ}$. O provimento dos cargos de Professor de Desenvolvimento Infantil será na conformidade do Anexo I, integrante desta lei, mediante concurso público, de provas ou de provas e títulos (SÃO PAULO, 2003).

A partir de então, somente puderam ingressar no cargo como PDIs os (as) profissionais que possuíssem formação para tal, ou seja, no mínimo o magistério, sendo o ingresso por meio de concurso público. Sobre as atribuições referentes aos cargos de PDI, este tem suas funções pautadas nas concepções de criança e de educação infantil constantes da Constituição de 1988 e da LDB n 9.394/96, as quais sublinham o desenvolvimento integral da criança e reconhecem o educar e o cuidar enquanto funções indissociáveis. 
Desse modo, caberia aos (às) PDIs, de acordo com o Decreto n ${ }^{\circ} 44.846$, de 14 de junho de 2004, as seguintes atribuições:

I - participar, em conjunto com a equipe técnica e a comunidade educativa, da elaboração, execução e avaliação do projeto políticopedagógico;

II - planejar, coordenar, executar e avaliar as atividades pedagógicas, possibilitando o desenvolvimento integral da criança, em complementação à ação da família e da comunidade;

III - desenvolver ações educativas que promovam a prevenção e proteção do bem-estar coletivo;

IV - dialogar com os pais ou responsáveis sobre as propostas de trabalho, o desenvolvimento e a avaliação das atividades;

V - responsabilizar-se pelo cuidado, pela observação e pela orientação para que todas as necessidades de saúde, higiene e alimentação sejam cumpridas nas diferentes idades;

VI - organizar os ambientes e materiais utilizados no desenvolvimento das atividades;

VII - organizar e reorganizar os tempos e os espaços, de forma a permitir a interação entre as crianças e das crianças com os adultos, favorecendo a autonomia e a manifestação e produção da cultura infantil;

VIII - observar as crianças durante o desenvolvimento das atividades, procedendo ao registro mediante relatórios que constituam avaliação contínua dentro do processo educativo;

IX - respeitar acriança como sujeito do processo educativo, favorecendo seu desenvolvimento em todos os aspectos por meio de situações lúdicas e criativas;

$\mathrm{X}$ - participar de cursos, palestras, encontros e outros eventos afins, buscando, em processo de formação permanente, o aprimoramento de seu desenvolvimento profissional e a ampliação de seus conhecimentos;

XI - contribuir com os subsídios de sua formação para a transformação das práticas educativas do Centro de Educação Infantil; XII - participar das reuniões de equipe mantendo o espírito de cooperação e solidariedade com os funcionários do Centro de Educação Infantil, a família e a comunidade (SÃO PAULO, 2004a).

Com relação à formação, essa transformação significou, para o Centro de Educação Infantil, a conquista, pelo menos na letra da lei, de três horas semanais destinadas ao desenvolvimento de atividades educacionais e pedagógicas, no contexto da instituição. É o que afirma a Lei no $13.574 / 2003$ :

Art. $8^{\circ}$. O Professor de Desenvolvimento Infantil fica sujeito à Jornada Básica de 30 (trinta) horas de trabalho semanais - J-30.

Parágrafo único. Do total de horas previstas no "caput", 3 (três) horas serão destinadas ao desenvolvimento de atividades educacionais e pedagógicas (SÃO PAULO, 2003). 
Não obstante a conquista na forma da lei, essa determinação não foi cumprida na prática, uma vez que não havia nenhuma medida que a viabilizasse. Dessa forma, os momentos de formação destinados aos(às) PDIs resumiam-se a encontros bimestrais organizados por microrregiões ${ }^{11}$, nos quais se reuniam CEIs, Escolas Municipais de Educação Infantil (EMEIs) e as Escolas Municipais de Ensino Fundamental (EMEFs) mais próximas, sob a coordenação das equipes das Coordenadorias de Educação, com vistas, entre outras atividades, à troca de experiências. Do exposto, pode-se concluir que, embora os (as) profissionais do CEI fossem reconhecidos(as) como professores(as), em alguns aspectos não gozavam dos mesmos direitos da categoria. Esse trato por parte do município em relação aos PDIs somente reafirma o ranço assistencialista que predomina nas concepções dominantes, ou seja, o entendimento de que a formação contínua dos profissionais do CEI é questão secundária. Tal concepção provavelmente está relacionada à forma como a educação infantil se consolidou nos países subdesenvolvidos, entre eles o Brasil.

Para Rosemberg (2002, p. 35),

Um fértil e variado menu para orientar a expansão da Educação Infantil (EI) foi formulado, no período, e divulgado por publicações e seminários em diversas línguas. Apesar da variedade, os ingredientes básicos foram selecionados dentro dos custos, ou melhor, do parco investimento público na linha de chegada: educadores(as) ou professores(as) leigos(as), isto é, não profissionais, justificando salários reduzidos; espaços improvisados, mesmo quando especificamente construídos para a EI; improvisação, também, de material pedagógico, ou sua escassez, como brinquedos, livros, papéis e tinta. A educação infantil para os países subdesenvolvidos tornou-se a rainha da sucata. $\mathrm{O}$ modelo redundou numa sinergia perversa entre espaço inadequado, precariedade de material pedagógico e ausência de qualificação profissional da educadora, resultando em ambientes educacionais pouco favoráveis ao enriquecimento das experiências infantis.

Não há dúvidas de que a trajetória histórica das creches no Brasil, e particularmente em São Paulo, é determinante na forma como o Poder Público municipal e a sociedade enxergam essas instituições, seus profissionais e suas práticas. Nessa perspectiva, as propostas de formação continuada voltadas ao CEI começaram a surgir na rede municipal de forma bem tímida. Um exemplo disso foi a constituição do

\footnotetext{
${ }^{11}$ Subdivisão de regiões da cidade de São Paulo.
} 
programa "A Rede em rede", cujo ponto de partida foi o documento Tempos e espaços para as crianças e suas linguagens nos CEIs, Creches e EMEIs.

Cabe, aqui, fazer somente uma breve descrição do documento, uma vez que ele será abordado de forma mais ampla no capítulo 3 desta dissertação. Tratou-se de uma publicação da equipe de Diretoria de Orientação Técnica da Educação Infantil (DOTEI). Além de advogar uma concepção de educação infantil pautada na abordagem histórico-social, propunha vários temas para serem discutidos entre os(as) educadores(as), tais como: integração do educar e cuidar; concepções de aprendizagem e desenvolvimento; organização dos tempos, espaços e materiais; relação entre cultura, infância e brincadeira; e diferentes linguagens na educação infantil (SÃO PAULO, 2006b).

Chegou-se à conclusão de que o documento em si pouco representava para a rede, se não pudesse gerar discussões que institucionalizassem algumas práticas. Inicialmente, o programa atribuía ao(à) coordenador(a) pedagógico(a), se não toda, quase toda a responsabilidade pelo melhoramento das práticas pedagógicas no CEI.

\begin{abstract}
É consenso no meio educacional que o aperfeiçoamento do trabalho realizado com as crianças na Educação Infantil requer um conjunto variado, contínuo e cuidadosamente planejado de situações voltadas para a formação continuada dos professores. O cotidiano escolar apresenta inúmeras demandas que extrapolam as ações dos professores na relação direta com as crianças. O Coordenador Pedagógico é capaz de responder a todas essas demandas e enfrentar inúmeros problemas complexos, cuja solução depende de um olhar atento, informado e peculiar em cada unidade educacional. Ele não é um mero gestor de sistemas e de boas práticas, e sim um parceiro institucionalmente designado para cuidar da tarefa de formação continuada docente nas unidades de nossa Rede (SÃO PAULO, 2013, sem paginação).
\end{abstract}

A primeira fase do projeto, iniciada em 2006, contemplava a formação das professoras e professores que atuavam no CEI de forma indireta, por meio do(a) coordenador(a) pedagógico(a). Contudo, no contexto da instituição, devido à carga de trabalho pela qual era responsável, nem sempre a coordenação conseguia efetivamente se dedicar à formação docente. Outro fator a se considerar era o tempo disponível: ainda não havia como alocar as três horas estabelecidas em lei para a realização desse fim, pois as crianças permaneciam 12 horas na instituição. Dessa maneira, o(a) coordenador(a) pedagógico(a) deveria fazer a formação das professoras e professores do CEI em horário de trabalho, sem que houvesse tempo e espaço para essa prática. 
Em 2007, a SME/DOT-EI publicou as Orientações Curriculares: expectativas de aprendizagem e orientações didáticas para a Educação Infantil. Trata-se de um conjunto de orientações que poderiam auxiliar o planejamento do trabalho educativo nos CEIs e EMEIs. Como objetivos, as orientações apresentavam:

1) Servir de referência para o trabalho dos professores e suscitar-lhes uma atitude reflexiva enquanto planejadores dos ambientes de aprendizagens das crianças. 2)Subsidiar cada professor na estruturação de um programa de atividades para as crianças de sua turma. 3) Apoiar cada equipe no planejamento, desenvolvimento e avaliação de seu projeto pedagógico, instrumento que define os conteúdos e as aprendizagens que eles buscam mediar com suas crianças. 4) Intensificar a articulação dos CEIs, creches, EMEIs e EMEFs, hoje integrados na rede municipal de ensino, em torno de diretrizes comuns e de um conjunto de aprendizagens que podem ser promovidas com cada grupo de crianças, de modo a dar continuidade às experiências das crianças em seu processo educacional. 5) Criar um recurso de comunicação que informe as famílias das crianças matriculadas nas instituições de educação infantil da rede municipal de ensino sobre as perspectivas de trabalho pedagógico que estão sendo discutidas nas unidades (SÃO PAULO, 2007, p. 10).

Não serão aprofundadas neste momento as concepções e propostas explícitas ou implícitas nesse documento. Basta dizer que ele representava um conjunto de orientações pautadas em princípios que envolviam o desenvolvimento infantil, o educar e cuidar, a inclusão, a parceria com as famílias e o papel do(a) professor(a) mediador(a). Apresentava também as aprendizagens que deveriam ser promovidas na educação infantil de 0 a 5 anos. Ao fim, havia um conjunto de expectativas de aprendizagens, bem como as orientações didáticas para atingi-las. Portanto, o documento dizia o quê e como o(a) professor(a) deveria ensinar, bem como as aprendizagens que as crianças deveriam adquirir em cada faixa etária.

Como medida para que as orientações fossem implementadas, investiu-se na formação do(a) professor(a). Nesse cenário, no ano de 2008, por meio da Portaria SME $\mathrm{n}^{\mathrm{o}}$ 1.566, de 18 de março de 2008, os Projetos Especiais em Ação (PEAs), que configuravam um espaço de formação já consolidado nas EMEIs e nas EMEFs, passaram a vigorar no CEI. A referida Portaria apresenta a definição atual para os Projetos Especiais em Ação e suas funções na educação infantil.

Art. $1^{\circ}$. Os Projetos Especiais de Ação (PEAs) são instrumentos de trabalho elaborados pelas unidades educacionais, que expressam as prioridades estabelecidas no projeto pedagógico, voltadas 
essencialmente às necessidades dos educandos, definindo as ações a serem desencadeadas, as responsabilidades na sua execução e avaliação, visando ao aprimoramento das práticas educativas e consequente melhoria da qualidade de ensino, atendendo as seguintes especificidades:

I - Na Educação Infantil: assegurar a todas as crianças a vivência de experiências significativas e variadas, utilizando diferentes linguagens, entendendo as práticas sociais da linguagem oral e escrita como organizadoras dessas experiências (SÃO PAULO, 2008a).

Com a determinação legal de que os PEAs poderiam ser realizados também no CEI, o horário de efetivo trabalho com as crianças passou de 12 para 10 horas, como prevê a Portaria SME n⿳ 4.618, de 17 de novembro de 2008, que dispôs sobre a organização das Unidades Educacionais da Rede, entre elas o CEI, nos seguintes termos:

Art. 11. Os Centros de Educação Infantil - CEIs e as Escolas Municipais de Educação Infantil-EMEIs, da Rede Municipal de Ensino, visando ao pleno atendimento da demanda e a garantia das diretrizes da Secretaria Municipal de Educação, deverão funcionar na seguinte conformidade:

I - Os Centros de Educação Infantil - CEIs da rede direta organizarão seu horário de funcionamento no período compreendido entre 7h00 e 19h00, observando-se:

a) o atendimento às crianças realizar-se-á de segunda a sexta-feira, em período integral de 10 (dez) horas, respeitada a necessidade da comunidade.

b) quando houver manifestação expressa do pai ou responsável pela criança, o horário de atendimento poderá ser flexibilizado para 5 (cinco) horas diárias, respeitadas a solicitação e a necessidade da família.

c) a fim de assegurar o atendimento à comunidade poderão ser organizados agrupamentos que iniciem as atividades em horários diferenciados.

d) a equipe gestora deverá assegurar o cumprimento das horasatividade docentes, dentro do período estabelecido no inciso I deste artigo e fora do horário de regência do Professor (SÃO PAULO, 2008b).

Por meio dessa Portaria, foram previstas condições para que, nas creches, houvesse três horas de trabalho coletivo destinadas à formação docente em serviço e duas horas individuais para, entre outras coisas, o planejamento do trabalho com as crianças. Nesse período, um dos principais objetivos da formação contínua no âmbito de CEIs e EMEIs era: 
[...] a implantação dos programas "Ler e Escrever - prioridade na Escola Municipal" e "Rede em rede: a formação continuada na educação infantill", "Orientações Curriculares: Expectativas de aprendizagens e orientações didáticas", "Referencial sobre avaliação da aprendizagem de alunos com necessidades educacionais especiais" e outros (SÃO PAULO, 2008a).

Nesse contexto, os PEAs, assim como o programa "A Rede em rede", pareciam estar a serviço da implementação das orientações curriculares por meio da formação docente (BELTRAN, 2012).

Retomando a discussão a respeito do programa "A Rede em rede", no ano de 2008, apareceu como seu principal objetivo a implementação das orientações curriculares e expectativas de aprendizagem para educação infantil (SÃO PAULO, 2008c). A partir de 2009, os(as) professores(as) começam a fazer parte do programa, ou seja, além da formação dos(as) coordenadores(as) e diretores(as), havia também formação para os(as) docentes. Nessa etapa, a meta do programa era “[...] promover a todas as crianças matriculadas na educação infantil a vivência de experiências com as diferentes linguagens e saberes que circulam em nossa sociedade baseados pelos princípios que norteiam as orientações curriculares" (SÃO PAULO, 2009).

As Orientações Curriculares (OCs, como são chamadas na rede municipal de educação), embora fossem somente orientações, deveriam constar no planejamento do(a) professor(a). Além disso, tendo-as como base, os cursos oferecidos para professores(as) e coordenadores(as) pelo "A Rede em Rede" abrangiam, separadamente, linguagens como artes plásticas, música, movimento, desenho, narrativas infantis, leitura e reconto etc.

A formação foi organizada em sequências de encontros com professores, às vezes mediados por outros agentes. Trabalhamos diretamente com os que estão na ponta, nas salas de aula, na companhia das crianças. Os encontros são estruturados em pautas comuns a todos os formadores, em todos os pólos da cidade. Esse é um recurso que visou assegurar o conteúdo mínimo de cada encontro, oferecer bons materiais de apoio ao professor e ajudá-lo a organizar seus registros. Nos encontros, cada formador deu à pauta o seu tom, contribuiu com a sua experiência, seu repertório, seus exemplos. A performance diferenciada do grupo, as singularidades de cada formador tornam os cursos únicos para cada grupo. Em comum, tínhamos todos certo protocolo básico que é também marca da metodologia empregada nesse programa (SÃO PAULO, 2010, p.9). 
No fragmento acima, nota-se o caráter que assumia tal formação. As pautas comuns revelam a crença de que todos(as) os(as) professores (as), de todas as unidades, necessitavam ter formação nos mesmos moldes, desconsiderando, portanto, a especificidade de cada grupo e de cada localidade, em nome de uma base comum de conhecimentos.

Entre as concepções que pautavam a formação docente no programa "A Rede em Rede" destacava-se uma que apresentava o (a) professor(a) enquanto sujeito de sua própria aprendizagem. No entanto, isso parece contraditório com a prescrição de tarefas como meios para sua aprendizagem.

\begin{abstract}
ORIENTAÇÃO PARA O $2^{\circ}$ TRABALHO PESSOAL
Professor (a),

Dando continuidade às atividades que constituirão seu Trabalho Pessoal (TP), estamos acrescentando à sua pasta de TPs mais uma página, agora com as orientações para o $2^{\circ}$ momento de Trabalho Pessoal desse curso. No próximo encontro, você deve trazer para compartilhar em seu grupo um pouco da cultura do faz de conta das crianças de sua comunidade, Unidade em que você trabalha. Uma boa maneira de conhecer as brincadeiras das crianças é participar dos parques ou dos momentos destinados a essa brincadeira, observar e registrar o que se passa. Não apenas relatar o que você vê, mas, principalmente, o que as crianças dizem, como elas desenvolvem os papéis, os cenários, as histórias que querem viver ao fazer de conta (SÃO PAULO, 2010, p.15).
\end{abstract}

No mesmo sentido são propostos alguns modelos para a realização dos registros de observação e, em seguida, são dadas as instruções para que cada professor(a) os realize:

1. Observe e registre durante a semana as diferentes manifestações da linguagem oral que acontecem no cotidiano da sua unidade. Procure focalizar seu relato nas interações estabelecidas entre crianças e adultos, identificando em que situações esses diálogos e conversas acontecem focar as interações e as dinâmicas das próprias crianças durante a brincadeira (SÃO PAULO, 2010, p.16).

Não se propõe previamente uma discussão política que diz respeito às práticas de registro que certamente já estarão em uso nas instituições. Como essas práticas foram consolidadas? Porque elas ocorrem dessa e não de outra maneira? Tocar nessas questões provavelmente suscitará discussões políticas e talvez indesejadas a respeito das condições necessárias e favoráveis a boas práticas de registro. Essas são discussões que não ocorrem quando se busca uniformização de pensamentos e práticas por meio da 
formação continuada. Nesse sentido, ensinar passo a passo como se educa torna-se a melhor maneira de alcançar resultados imediatos e sem nenhum sentido para aqueles e aquelas que são os sujeitos dessa prática.

É importante observar que, para reafirmar essa política de formação, foram lançados, em 2010, os Cadernos da Rede. Com esse material, pretendia-se “[...] promover, além de boas reflexões, a ressignificação das práticas, a ampliação e a vivência de boas e significativas experiências com as crianças matriculadas nas Unidades da Rede Municipal de Educação de São Paulo" (SÃO PAULO, 2010, p.7).

Cada publicação trazia os percursos de aprendizagem do grupo de formação dentro da linguagem abordada. Entre os títulos, estão: "Narrativas infantis no jogo de faz de conta"; "Percursos de aprendizagem leitura e reconto"; "Percursos de aprendizagem o corpo e o movimento criativo" etc. Esses apresentavam princípios teóricos envolvendo a temática tratada, textos de formadores(as) e de professores(as). Os textos que constavam do livreto, produzidos por professores(as), eram geralmente relatos de sua prática, envolvendo os conteúdos presentes no curso de formação. Aqueles produzidos pelos(as) formadores(as) traziam relatos sobre como se dava esse processo (SÃO PAULO, 2010). Além de se configurar como uma abordagem focada mais na execução de tarefas do que na reflexão crítica do(a) professor(a), A Rede em Rede não atingia todos os profissionais do CEI, uma vez que não havia vagas suficientes para atender às demandas presentes na rede. Dessa maneira, eram realizados sorteios dentro das unidades. Nesses sorteios, geralmente, duas vagas eram disputadas por período em cada Centro de Educação Infantil. 


\section{PROPOSTAS CURRICULARES PARA AS CRECHES: INSPIRAÇÕES E PRÁTICAS PRESENTES}

A referência a uma dimensão curricular, quando se trata da educação infantil de 0 a 3 anos, não é uma tradição no campo. Falar da dimensão educativa das creches sob a ótica do currículo é, antes de tudo, problematizar aspectos relativos a ideologias, teorias educacionais e gramáticas pedagógicas que influenciam as práticas cotidianas nessas instituições.

Há que se admitir que a creche, em sua essência, é um ambiente educativo, pois nesse contexto, ocorre o desenvolvimento de práticas e vivências que influenciam diretamente o modo de ser, agir e sentir de meninos e meninas. Todas essas ponderações geraram a construção desse capítulo que pretende aprofundar as discussões e reflexões relativas aos modelos curriculares para a educação infantil de 0 a 3 anos, atentando para as influências desses modelos sobre as propostas curriculares para as creches no âmbito municipal de São Paulo.

\subsection{Delineando um conceito de currículo na Educação Infantil.}

A ideia de currículo esteve, por muito tempo, atrelada essencialmente às questões dos conteúdos de ensino, com relação estreita à organização das disciplinas em uma perspectiva transmissiva dos saberes, desconsiderando-se as experiências dos educandos como fator importante para se pensar as propostas curriculares.

Goodson (1995, p. 43) explica as origens da concepção curricular enquanto sequência estruturada ou disciplina da seguinte maneira: “[...] o conceito de currículo como sequência estruturada ou 'disciplina' provém, em grande parte, da ascendência política do Calvinismo. Desde esses primórdios houve uma 'relação homóloga entre currículo e disciplina"”. Porém, a concepção tradicional do currículo pode ser melhor compreendida se relacionada com o surgimento das teorias nesse campo. De acordo com Silva (1999), as teorias a respeito do currículo começaram a ganhar consistência a partir dos escritos de Bobbitt, em 1918. Para esse autor, o currículo resumia-se a um modelo fabril, em que a palavra de ordem era a eficiência.

O sistema educacional deveria começar por estabelecer de forma precisa quais são seus objetivos. Esses objetivos, por sua vez, 
deveriam se basear no exame daquelas habilidades necessárias para exercer com eficiência as ocupações profissionais da vida adulta (SILVA, 1999, p.23).

$\mathrm{Na}$ contramão dessa corrente, as formulações apresentadas por Dewey, desde 1902, pautadas em um ideário progressista, propunham um currículo que contemplasse a vivência democrática e não a mera preparação para a vida adulta. As proposições de Dewey não receberam grande reconhecimento em virtude do objetivo maior da educação naquela época, que se resumia à preparação para a vida adulta e para o mundo do trabalho.

Tanto o modelo técnico de Bobbitt como o modelo progressista de Dewey sofreram contestações nos Estados Unidos no final dos anos de 1970, com o chamado "movimento de reconceitualização do currículo" (SILVA, 1999). Enquanto as teorias tradicionais sobre o currículo se abstinham de questionar a tessitura educacional existente e seus pressupostos, as teorias críticas assumiam uma posição de confronto.

As teorias críticas desconfiam do status quo, responsabilizando-o pelas desigualdades e injustiças sociais. As teorias tradicionais eram teorias de aceitação, ajuste, adaptação. As teorias críticas são teorias de desconfiança, questionamento e transformação radical. Para as teorias críticas o importante não é desenvolver técnicas de como fazer o currículo, mas desenvolver conceitos que nos permitam compreender o que o currículo faz (SILVA, 1999, p.30, grifos do autor).

Embora a teoria crítica inicialmente se dirigisse a discussões essencialmente ligadas aos conceitos de ideologia, reprodução e resistência, ela foi aos poucos tomando outras proporções, chegando a fatores mais profundos, como, por exemplo, os significados que os sujeitos dão às suas experiências pedagógicas e curriculares.

Na contemporaneidade, a concepção de currículo não se restringe ao universo escolar, mas envolve, para além disso, o contexto local, os educandos, suas famílias, culturas e saberes. Dessa maneira, o currículo contemporâneo não se limita

[...] nem à supervalorização da cultura que trazemos, nem à supervalorização da cultura popular, mas a possibilidade de se ter a sala de aula como um espaço de ressignificação de conhecimentos, de produção de novos conhecimentos, de problematização dos diferentes conhecimentos, tal como eles estão postos na sociedade (GARCIA; MOREIRA, 2003, p.9). 
O currículo, nesses termos, não pode ser concebido enquanto um conjunto de conhecimentos disciplinares engessados. Os saberes provindos de diferentes fontes assumem igual importância, sem hierarquização. Nesse contexto, cabe à instituição educativa romper com práticas tradicionais, conteudistas e controladoras, dando lugar à reflexão, participação e problematização, com vistas à produção de significados por parte dos sujeitos envolvidos no processo educativo. Nessa perspectiva, não cabem a fragmentação e a compartimentação do conhecimento, uma vez que essa divisão impossibilita um pensar contextualizado que conduz à emancipação (FREIRE, 1970).

Desta perspectiva, o currículo ganha um caráter político e histórico, revelando-se como local privilegiado na produção de significados e valores sociais, ou seja, o campo pedagógico e o campo cultural tornam-se parte, portanto, de uma política cultural (GIROUX, 1986).

Stenhouse (1991) compreende o currículo como um processo pautado no respeito à natureza dos conhecimentos, no processo de aprendizagem e no processo de ensino, além de apontar a investigação como ponto inicial para se pensar a construção das propostas curriculares e a melhoria do ensino. Por isso, considera importante envolver os professores na discussão e construção dessas propostas.

Goodson (2007) concebe o currículo como uma narrativa, contrapondo-se à inércia do currículo prescritivo. O autor defende o currículo narrativo aproximando-o do contexto de uma modernidade líquida (BAUMAN, 2003). Dessa maneira, o currículo narrativo concebe a aprendizagem

[...] como algo ligado à história de vida é entender que ela está situada em um contexto, e que também tem história - tanto em termos de histórias de vida dos indivíduos e histórias e trajetórias das instituições que oferecem oportunidades formais de aprendizagem, como de histórias de comunidades e situações em que a aprendizagem informal se desenvolve (GOODSON, 2007, p.250).

É importante notar que são muitas as formulações acerca do currículo na atualidade. A construção histórica em torno dessa temática mostra que o currículo ultrapassa a mera proposição de conteúdos e ideologias, ele é um espaço plural em que coexistem ideias que estão à frente do que afirmam as teorias tradicionais. Nesse sentido, 
O currículo é lugar, espaço, território. O currículo é relação de poder. O currículo é trajetória, viagem, percurso. O currículo é autobiografia, nossa vida, curriculum vitae; no currículo se forja nossa identidade. $\mathrm{O}$ currículo é texto, discurso, documento. O currículo é documento de identidade (SILVA, 1999, p.150).

Transpondo a discussão para o campo da educação infantil, um currículo que contemple as crianças pequenas de 0 a 3 anos necessita estar comprometido com as especificidades dessa faixa etária, reconhecendo meninas e meninos em seu contexto histórico, social e cultural, assumindo um processo dialógico que transcenda o território institucional, de forma a considerar os saberes e as vivências dos sujeitos envolvidos.

\subsection{As matrizes pedagógicas e suas relações com as construções curriculares para a primeira Infância.}

Em meados do século XIX, surge o pensamento pedagógico froebeliano como um projeto emancipador na educação infantil. Froebel concebia a criança como ser criativo e propunha uma educação pautada na autoatividade e no jogo. Nas palavras de Kishimoto e Pinazza (2007, p. 38),

O jardim de Infância de Froebel tornou-se conhecido pelo cultivo da vida social livre e cooperativa, que destoava de tendências políticosociais restritivas e autoritárias que persistiam na Alemanha, as quais impossibilitavam pensar a continuidade do mundo exterior no interior da instituição infantil.

Froebel surge então como um dos grandes pensadores da educação Infantil: defende uma educação para a infância que não visa a aquisição de conhecimento e sim a promoção do desenvolvimento; contrapõe-se ao conceito de educação como preparação para um estado futuro, afirmando que a vida a criança deve ser inserida não na vida do adulto, mas na vida que a rodeia no presente. Ao acreditar em uma força natural que emana do próprio homem impulsionando-o ao desenvolvimento, defendeu a educação com base na liberdade e no respeito às capacidades de cada indivíduo (KISHIMOTO; PINAZZA, 2007).

Na pedagogia froebeliana o brincar assume papel central 
Ao propor, no brincar, a trilogia: criar, sentir e pensar, Froebel mostra o valor da ação criativa da criança, o papel das emoções e a integração do pensamento na ação (KISHIMOTO; PINAZZA, 2007, p.51).

Mais adiante, na primeira metade do século XX, o movimento da Escola Nova impulsiona a educação infantil, vive-se um clima de renovação e de sensibilidade em relação às necessidades das crianças menores (ARRIBAS, 2004). Como figuras significativas desse momento histórico, é possível citar: John Dewey, Maria Montessori e Celestin Freinet, dentre outros.

John Dewey, apesar de não tratar especificamente da educação infantil, em seus escritos, faz uma forte crítica à educação tradicional e reafirma a importância da aprendizagem pela experiência. Para Dewey, a escola e os educadores devem saber como extrair dos ambientes físicos e sociais tudo o que pode contribuir para fortalecer experiências valiosas. Cabe à educação reconhecer no ambiente quais experiências podem ser favoráveis e como eventualmente nela se operam as forças internas e externas (PINAZZA, 2007).

Entre as importantes marcas impressas por Dewey na Educação Infantil está o trabalho com projetos

O trabalho com projetos concretiza-se na prática educativa quando se consideram como ponto de partida os interesses e as experiências infantis e se propicia a ampliação dessas experiências para outras cada vez mais complexas e elaboradas. Isso se faz mediante um processo de investigação protagonizado pela criança, sob o olhar atento do adulto, que, tendo intenções claras em seu trabalho educativo, oferece suporte, organiza situações e registra as experiências em desenvolvimento (PINAZZA, 2007, p.86).

Maria Montessori também se destacou por meio de sua perspectiva educacional. Tal perspectiva assentava-se numa pedagogia fundamentada em diferentes ciências tendo como foco a educação, a cultura, o organismo e a fisiologia do corpo humano, elementos de cuja articulação depende fundamentalmente o desenvolvimento do homem livre e autônomo. O ideal de escola, nessa chave, reside em propiciar e garantir as manifestações espontâneas da personalidade da criança, permitindo o livre desenvolvimento da atividade no ser humano em sua infância (ANGOTTI, 2007; ARAÚJO \& ARAÚJO, 2007).

Montessori reconheceu a criança como exploradora, cientista que vai desvendar o mundo. Por isso, o espaço educativo deve ser preparado e pensado de forma a oferecer 
condições para que as crianças possam observar, explorar e conhecer em liberdade. Nessa linha, o papel do adulto é o de organizador do espaço e grande observador das ações infantis.

A professora deverá aprender com a criança sobre a própria criança e sua natureza por meio da observação atenta de seus períodos sensíveis, de seus interesses e necessidades latentes, permitindo-lhe o aflorar do potencial latente e da satisfação dos mesmos (ANGOTTI, 2007, p. 109).

Outro personagem que se destacou no pensamento pedagógico do século XX foi Freinet. Com uma proposta educativa comprometida com a criança e com sua efetiva participação na escola, na família e na comunidade, Freinet mostrou-se sensível ao defender uma escola centrada na criança, a qual deveria ser vista não como indivíduo isolado, e sim como parte de uma comunidade com direitos e deveres e, portanto, capaz (ELIAS; SANCHES, 2007; ARAÚJO \& ARAÚJO, 2007).

O intuito de Freinet era elaborar técnicas pedagógicas que contribuíssem para a transformação do processo educativo. O ideal era possibilitar a todas as crianças independentemente da classe social, o acesso a uma educação que lhes promovesse o desenvolvimento e a cidadania (ELIAS; SANCHES, 2007, p. 165).

Nos anos 60 e 70 do século XX, as teorias do desenvolvimento influenciam de maneira decisiva o debate sobre modelos curriculares para a infância, principalmente por meio dos nomes de Piaget, Vygotsky e Bruner. Esta influencia faz emergir concepções sobre aprendizagem infantil centradas nas suas interações com o meio e com o outro (VIEIRA; LINO, 2007: PIMENTEL, 2007).

Todos esses postulados contribuíram de forma significativa para a compreensão da criança pequena e suas formas de aprender e conhecer o mundo, o que repercutiu profundamente nas maneiras de pensar o currículo para a infância na atualidade. $O$ pensamento curricular sobre a primeira infância está pautado atualmente, sobretudo, em gramáticas pedagógicas de tradições interacionista construtivista e socioconstrutivista.

Resultam dessas orientações, aqui apresentadas sob diferentes matizes, os modelos de High Scope (EUA), Reggio Emilia (Itália), Movimento da Escola Moderna (MEM) (Portugal) e, mais recentemente, a abordagem da Associação Criança, Pedagogia em Participação (Braga, Portugal), que desempenham um papel de grande expressão no pensamento pedagógico brasileiro e, especialmente, paulistano. 


\subsection{Abordagens curriculares para Educação Infantil: inspirações da High/Scope, Reggio Emilia, Movimento da Escola Moderna e Pedagogia em Participação.}

Observa-se que as abordagens curriculares citadas anteriormente têm sido as mais praticadas e difundidas na educação infantil. Por esse motivo, considera-se importante contextualizá-las, ainda que de forma breve, explicitando suas características centrais a fim de melhor compreendê-las, o que certamente facilitará o entendimento do nosso próprio contexto educacional.

\subsubsection{Abordagem High/Scope}

O currículo High/Scope possui fortes influencias tanto da perspectiva desenvolvimentista como da pedagogia deweyana. Trata-se de uma abordagem em que a criança possui papel ativo na construção do seu conhecimento, ou seja, essa construção não é estática, mas fruto de ações que, por sua vez, são interpretadas como parte do desenvolvimento de estruturas mentais. Segundo essa concepção, a criança aprende fazendo por meio da vivência com o outro e da resolução de problemas.

O currículo High/Scope surge nos anos 60 do propósito de David Weikart, seu idealizador, de preparar crianças com necessidades educacionais especiais para ingressar na escola. Desde então, passou por várias fases e transformações que vão desde a concepção de educação compensatória até a compreensão de que a criança é o motor da aprendizagem no diálogo (OLIVEIRA-FORMOSINHO, 2007). Nas palavras de Weikart,

O currículo High/Scope é uma abordagem aberta de teorias do desenvolvimento e práticas educacionais que se baseia no desenvolvimento natural das crianças. Atualmente este currículo é usado em milhares de programas de educação infantil nos Estados Unidos e em outros países. Baseado nas ideias de Piaget acerca do desenvolvimento infantil, o Currículo High/Scope considera a criança como aprendiz ativo que aprende melhor a partir das atividades que ela mesma planeja, desenvolve e sobre as quais reflete. Os adultos organizam as áreas de interesse no ambiente de aprendizagem; mantêm a rotina diária que permite às crianças o planejamento e busca de suas próprias atividades; e juntam-se às atividades das crianças para ajudá-las a refletir. Os adultos encorajam as crianças a envolverem-se em experiências-chave, ajudam-nas a aprender a fazer escolhas, a resolver problemas e a engajar-se em atividades que promovam o desenvolvimento intelectual, social e físico. Décadas de pesquisas indicam que isto funciona, promovendo significativamente 
as oportunidades de vida das crianças participantes (WEIKART, 2004, p. 23).

No contexto da abordagem curricular High/Scope, a organização do ambiente físico, da rotina, bem como das interações adulto/criança, adulto/adulto configuram-se como importantes fatores para a prática pedagógica com as crianças pequenas. Desta maneira, uma sala de atividade organizada em áreas de interesse: casinha, construção, fantasia, etc. proporciona às crianças ocasiões para desenvolver papeis sociais, vivências e experiências em cada área de forma ativa e autônoma. Nas palavras de Oliveira-Formosinho,

A organização do espaço em áreas e a colocação dos materiais nas áreas onde são utilizados são a primeira forma de intervenção da educadora ao nível do currículo High/Scope e, de um modo geral, ao nível dos currículos que se situam numa perspectiva construtivista (OLIVEIRA-FORMOSINHO, 2007, p. 68).

O currículo High/Scope não considera as atividades pré-estruturadas como parte processo de aprendizagem para a criança, por outro lado, tampouco considera que as atividades devam ocorrer de forma espontaneísta. Por isso, num contexto educacional High/Scope, a atividade deve surgir do contributo tanto das crianças como dos adultos, como uma (co)construção. Nesse sentido, a gestão do tempo, por exemplo, embora pensada pelo adulto, tem de ser progressivamente (co)construída pela criança. O adulto não pode aparecer e fazer a cada dia o que bem quiser, contudo a rotina tem de construída "com” as crianças, e não "para" elas. Como se vê, a rotina diária apresenta-se é um fator importante nessa abordagem curricular, pois a criança sente-se mais segura quando sabe o que espera, conhece bem o que antecedeu e sabe o que esta por vir (OLIVEIRA-FORMOSINHO, 2007).

Num contexto curricular High/Scope, a interação entre criança e o adulto se dá por meio do apoio que esse oferece àquela para resolver seus conflitos cognitivos, renovando seu empenho individual para enfrentar novas situações problema. Como a criança é figura central nesta concepção, suas ações são consideradas decisivas para a aprendizagem (OLIVEIRA-FORMOSINHO, 2007). Para Hohfmann e Weikart (1997, p. 22),

A aprendizagem pela ação-experiência direta e imediata de objetos, pessoas, ideias e acontecimentos é uma condição necessária para a reestruturação cognitiva e para o desenvolvimento. Posto de uma 
forma simples, a criança pequena aprende conceitos, forma ideias e cria os seus próprios símbolos ou abstrações através de atividade autoiniciada - move-se, ouve, procura, sente, manipula. Esta atividade leva a cabo num contexto social em que o adulto atento e sensível observador-participante, torna possível à criança estar envolvida em experiências intrinsecamente interessantes que podem vir a produzir conclusão contraditória e a desencadear uma consequente organização da compreensão que a criança faz do mundo.

Em sua essência, a abordagem curricular High/Scope se traduz no entendimento de que as aprendizagens infantis se dão diretamente pela ação das crianças sobre os objetos.

\subsubsection{Abordagem curricular de Reggio Emilia}

Localizada ao norte da Itália, Reggio Emília possui uma abordagem curricular que proporciona às crianças oportunidades para o pleno desenvolvimento de suas habilidades e potencialidades. Pelo próprio contexto histórico em que se deu a constituição da educação infantil nessa cidade, após a segunda guerra, o currículo praticado em Reggio assenta-se sobre princípios como a colaboração entre família, escola e comunidade. Além disso, a instituição de educação infantil é vista como um lugar de múltiplas relações (GANDINI, 1999; LINO, 2007).

Loris Malaguzzi, o grande representante dessa abordagem curricular, ao perceber o movimento de construção da primeira escola de educação infantil emiliana logo após a segunda Guerra Mundial, resolve tomar conhecimento e observar esse processo. É nesse momento que se apaixona pelo movimento de cooperação e colaboração que unia as pessoas dessa comunidade em torno de um ideal de educação infantil. Entre os envolvidos, havia professores e professoras, pais, mães e cidadãos. Os professores e professoras, apesar de seguirem diferentes filosofias educativas herdadas de sua formação inicial, têm em comum forte motivação e, sob a orientação de Loris Malaguzzi, iniciam um trabalho em equipe com vistas a compreender as crianças, suas necessidades e interesses. Este foi o ponto de partida para a experiência educacional de Reggio Emilia (LINO, 2007). No entender de Faria (2007),

Loriz Malaguzzi inaugura sua pedagogia em um pais milenar, colonizador e com um passado fascista. O trabalho coletivo na rede pública com professoras especializadas "em normalidade" garante 
para as crianças, parafraseando Marx, " as condições dadas" para elas fazerem história (FARIA, 2007 p. 286).

$\mathrm{Na}$ abordagem curricular de Reggio Emilia, no contexto da educação infantil, as relações estabelecidas com a criança estão obviamente no centro da abordagem, contudo é fundamental também as relações que se estabelece com a família, professores e professoras, nesse sentido, os atores são convidados a participar. Não se trata de uma participação somente em reuniões ou em momentos pontuais, mas, para além disso, defende-se uma participação de co-responsabilização, em que todos são responsáveis de fato pela educação de meninas e meninos. Nesse contexto, a escola deve se organizar e prover meios para que esses atores se sintam parte de todo o processo (EDWARDS, et. al. 1999; FARIA, 2007; LINO, 2007).

Ela deve incorporar meios de intensificar os relacionamentos entre os três protagonistas centrais, de garantir completa atenção aos problemas da educação e de ativar a participação e pesquisas. Estas são as ferramentas mais efetivas para que todos os envolvidos crianças, professores e pais - tornem-se unidos e conscientes das contribuições uns dos outros. Estas são as ferramentas mais efetivas para que nos sintamos bem cooperando e produzindo, em harmonia um nível superior de resultados (EDWARDS, C. GANDINI, L. FORMAN, G, 1999, p 75).

O currículo, nessa perspectiva, não é algo estático, algo programado externamente à instituição. Ao contrário disso, o currículo é a cada ano esboçado no terreno da própria unidade, que elabora uma série de projetos a serem desenvolvidos naquele contexto, projetos a curto, médio e longo prazo. Ainda que esses projetos sirvam como eixos norteadores, o processo fica a cargo das crianças, que assumem o papel de pequenos pesquisadores, levantando hipóteses, enfrentando desafios, conhecendo o mundo por meio de suas próprias pesquisas. Nesse processo, meninos e meninas assumem o papel de co-construtores do currículo à medida que algumas questões emergem de sua própria curiosidade e do olhar atento do adulto para compreender as demandas infantis. Não se trata, porém, de improvisação ou de acaso. Como afirma Malaguzzi (1999, p. 102),

As certezas fazem com que entendamos e tentemos entender. Desejamos estudar se a aprendizagem possui seu próprio fluxo, tempo e lugar; como a aprendizagem possui seu próprio fluxo, tempo e lugar; como a aprendizagem pode ser preparada, que habilidades e esquemas cognitivos valem a pena apoiar, como oferecer palavras, gráficos, pensamento lógico, linguagem corporal, linguagem simbólica, fantasia, narrativa e argumentação; como brincar; como 
fingir; como as amizades se formam e se dissipam; como a identidade individual e de grupo se desenvolve; e como emergem as diferenças e as similaridades.

Vale salientar que, na abordagem curricular de Reggio Emilia, a dimensão estética reflete-se no cuidado com o ambiente, o mobiliário, os objetos, os materiais, os locais para realização das atividades, na inclusão do atelier como espaço privilegiado para o desenvolvimento das múltiplas formas de expressão, na escuta das crianças, na documentação pedagógica dos processos e produtos que transcendem da visibilidade bem como no conhecimento que se constrói no âmbito de uma pedagogia das relações (LINO, 2007).

De fato, na abordagem emiliana para a Educação Infantil, cada fator assume sua devida importância. O espaço, por exemplo, não é visto como algo alheio ao processo, ao contrário disso, ele é também um educador em potencial e motivo de constantes intervenções e reflexões. Existem particularidades também no que se refere à rotina e o tempo. O tempo predominante não é o tempo institucional, respeita-se o tempo das crianças, a rotina é pensada de forma a garantir a educação e o cuidado de meninas e meninos respeitando suas particularidades e ritos próprios. No mais, são oferecidos às crianças diferentes desafios que proporcionem aprendizagens diversas, fazendo delas protagonistas de fato do aprendizado (FARIA, 2007; GANDINI,1999).

A escuta das crianças na abordagem curricular de Reggio Emilia, cujo eixo central encontra-se nas relações e na participação, deve ocorrer constantemente. Dentro de uma concepção de criança ativa, rica em recursos, conhecimentos, competente, criativa, sujeito de direitos e produtora de cultura, a criança precisa constantemente ser ouvida e respeitada em seus direitos. Segundo Faria (2007),

Diz respeito ao direito de as crianças realizarem e expandirem todas as suas potencialidades, valorizando suas próprias capacidades de socializar, colhendo afeto e confiança e satisfazendo suas necessidades de aprender, sobretudo quando os pequenos são tranquilizados por uma eficaz aliança com adultos prontos a contribuir com empréstimos e ajudas que privilegiam mais do que a transmissão de conhecimentos e habilidades, a busca de estratégias construtivas do pensar e do agir (FARIA, 2007, p. 288). 


\title{
3.3.3 Abordagem Curricular para Educação infantil da Escola Moderna Portuguesa
}

O Movimento da Escola Moderna (MEM) configura-se num projeto de autoformação cooperada entre docentes que transfere sua estrutura democrática e seus procedimentos para um modelo de cooperação educativa nas escolas de infância portuguesas. A abordagem curricular do MEM para a Educação Infantil está fundamentada nos pressupostos da pedagogia de Freinet, nesse contexto, termos como democracia, cooperação e trabalho em grupo são constantes. Nas palavras de Niza (2007, p. 127),

\begin{abstract}
A escola define-se para os docentes do MEM como um espaço de iniciação às práticas de cooperação e de solidariedade de uma vida democrática. Nela os educandos deverão criar com os seus educadores as condições materiais, afetivas e sociais para que, em comum, possam organizar um ambiente institucional capaz de ajudar cada a apropriar-se dos conhecimentos, dos processos e dos valores morais e estéticos gerados pela humanidade no seu percurso histórico-social.
\end{abstract}

A negociação é o princípio para as ações: caminha-se progressivamente por ela do planejamento à partilha das experiências e avaliação, uma vez que a instituição é vista como o lócus do diálogo e da construção das práticas e projetos. O MEM define um conjunto de princípios que atuam como estratégias que imprimem ao processo de ensino e aprendizagem maior sentido, a saber: do processo de produção para a compreensão, significa saber sobre o processo, fazer parte dele, compreender e ter consciência do percurso da constituição do próprio conhecimento; da intervenção para a comunicação, revela a necessidade de dar a conhecer o processo e a experiência vivida, dando sentido social imediato à aprendizagem e validando-a enquanto produção científica que necessita ser comunicada aos pares; da experiência pessoal para a didática " a posteriori", revela a necessidade de pensar juntos sobre tudo o que foi vivido, tendo em vista a necessidade de clarificação externa e reestruturação das experiências e aprendizagens, é o momento de reflexão individuais ou grupais com apoio teórico (NIZA, 2007).

No que diz respeito aos pressupostos do processo educativo, as palavras de Niza (2007, p. 131) são bastante esclarecedoras: 
Uma primeira condição em que se fundamenta a dinâmica social da actividade educativa no jardim-de-infância, no modelo curricular da Escola Moderna Portuguesa, é a da constituição dos grupos de crianças, não por níveis etários, mas, de forma vertical, integrando de preferência as várias idades para que se possa assegurar a heterogeneidade geracional e cultural que melhor garanta o respeito pelas diferenças individuais no exercício da interajuda e colaboração formativas que pressupõe este projecto de enriquecimento cognitivo e sociocultural. Uma outra condição, que se reporta historicamente ao trabalho inovador de Freinet, diz respeito à necessidade de se manter, permanentemente, um clima de livre expressão das crianças reforçado pela valorização pública das suas experiências de vida, das suas opiniões e ideias. Essa atitude tornar-se-á visível através da disponibilidade do educador para registar as mensagens das crianças, estimular a sua fala, as produções técnicas e artísticas e animar a circulação dessas realizações através de circuitos diversos que se alimentam desse labor de expor e comunicar. Indispensável se torna, igualmente, permitir às crianças o tempo lúdico da actividade exploratória das ideias, dos materiais ou dos documentos para que possa ocorrer a interrogação (Louis Legrand chama-lhe o espanto) que suscite projectos de pesquisa, auto-propostos ou provocados pelo educador, que alimentam, afinal, um modelo educativo como o da Escola Moderna que implica o desenvolvimento em simultâneo de projectos diversificados no trabalho educativo.

$\mathrm{Na}$ abordagem curricular do MEM, o espaço educativo é pensado de forma a favorecer experiências diversificadas em grupos ou individualmente. O sistema desenvolve-se a partir de um conjunto de seis áreas básicas de atividades distribuídas à volta da sala (conhecidas também por oficinas ou ateliers na tradição de Freinet) e de uma área central para o desenvolvimento do trabalho coletivo. Nas unidades que não possuem cozinha acessível organiza-se também uma área para cultura e educação alimentar.

As áreas básicas desenvolvem-se: num espaço para biblioteca e documentação; numa oficina de escrita e reprodução; num espaço de laboratório de ciências e experiências; num espaço de carpintaria e construções; num outro de atividades plásticas e outras expressões artísticas; e ainda num espaço de brinquedos, jogos e "faz de conta" (Ibidem, p.132).

A sala de atividades no contexto curricular da Escola Moderna Portuguesa deve compor um ambiente agradável e estimulante, as paredes, por exemplo, podem ser usadas como expositores permanentes da produção da turma. A propósito, os projetos surgem das atividades e vivências das crianças nas diferentes áreas, ou mesmo de uma 
questão que os pequenos gostariam de explorar e conhecer mais. A planificação dos projetos segue os seguintes passos :

1- Formulação: conversas em grupo na acolhida, identificação de um problema ou aspiração, formulação do projeto;

2- Balanço diagnóstico: levantamento do que se tem o que se sabe e o que se deseja saber sobre o tema;

3- Divisão e distribuição do trabalho: quem faz o quê? Como e quando?;

4- Realização do trabalho: desenvolvimento de estudos, pesquisa ou resolução de problemas (em grupos, pares ou individualmente);

5- Comunicação: partilhar com toda a turma o trabalho realizado, perguntas e opiniões da turma (NIZA, 2007).

Para o MEM, a organização da rotina deve ser pautada no diálogo constante e no respeito às crianças e, nesse sentido, a rotina está organizada em dois períodos: no primeiro período (manhã), realizam-se os trabalhos e atividades eleitos pelas crianças; no segundo período (tarde), ocorrem sessões plenárias de informação e de atividade cultural dinamizadas por pessoas convidadas pelos alunos ou pelos próprios educadores. Essa organização diária, de acordo com Niza (2007) desenvolve-se em nove etapas: acolhimento, planificação em conselho, atividades de projetos, pausa, comunicações de aprendizagem, almoço, atividades de recreio (canções, jogos tradicionais e movimento orientado), atividade cultural coletiva, balanço em conselho.

O educador, pautado em princípios democráticos, assume nesse contexto importante papel. Nas palavras de Niza (2007, p. 139),

\footnotetext{
Os educadores que sustentam este sistema de educação pré-escolar se assumem como promotores da organização participada; dinamizadores da cooperação; animadores cívicos e morais do treino democrático; auditores ativos para provocarem a livre expressão e a atitude crítica. Mantêm e estimulam a autonomização e responsabilização de cada educando no grupo de educação cooperada.
}

A parceria com as famílias aparece como fator fundamental nessa abordagem curricular, seu propósito maior é garantir o desenvolvimento educativo das meninas e meninos que freqüentam a instituição, de forma participada e dialógica, e por isso procura-se estabelecer parcerias com a família, com a comunidade e com os educadores 
em todos os momentos, seja para resolução de problemas cotidianos ou mesmo para mediar as produções culturais da comunidade (NIZA, 2007).

\subsubsection{Pedagogia-em-Participação: Abordagem da Associação Criança para a} Infância

A pedagogia-em-Participação assume como princípios a democracia e a liberdade. Uma das suas principais características é a escuta das crianças consideradas como sujeitos livres e de direitos. Como descreve Oliveira-Formosinho (2011, p.101),

A democracia está no coração das crenças da Pedagogia-emParticipação porque essa incorpora na sua missão a promoção da igualdade para todos e a inclusão de todas as diversidades. Isto implica a assunção de responsabilidade social pelas crianças e famílias e a promoção do sucesso educativo como instância de educação para a diversidade.

No contexto da Pedagogia-em-Participação, a atividade da criança é entendida como colaboração no âmbito do quotidiano educativo, de maneira que o papel do professor é o de organizar e ouvir as crianças para entendê-las e respondê-las. Nesse sentido, os princípios democráticos precisam estar presentes sendo vividos em todas as esferas da intervenção educativa: na definição das finalidades e objetivos educacionais, na escolha dos meios e técnicas para o desenvolvimento da ação pedagógica, na organização da instituição educativa, bem como na formação docente (OLIVEIRAFORMOSINHO, 2007; 2011).

A abordagem da Pedagogia-em-Participação considera o Centro de Educação Infantil como espaço democrático em que crianças e adultos encontram condições favoráveis ao exercício de suas capacidades agindo como seres livres, criativos e colaborativos e com capacidade para pensar de forma reflexiva e inteligente.

O objetivo da educação na Pedagogia-em-Participação são os de apoiar o envolvimento da criança no continuum experiencial e a construção da aprendizagem através da experiência interativa e continua, dispondo a criança tanto do direito a participação como do direito ao apoio sensível, autonomizante e estimulante por parte do(a) educador(a) (Idem, 2011, p.102)

As experiências que meninas e meninos vivenciam com os pares e com as professoras, desde a planificação, passando pela execução até a reflexão sobre as aquelas, ocorre de forma colaborativa. As experiências são motivadas pelo interesse das 
crianças em diálogo com as motivações profissionais das professoras e professores. Esses(as) assumem o papel de organizadores(as) do ambiente e do escutar, observando e documentando cada etapa do processo a fim de encaminhar ações futuras, considerando o ponto de vista das crianças (OLIVEIRA-FORMOSINHO, 2011).

De acordo com Oliveira-Formosinho (Ibidem), a Pedagogia-em-Participação apresenta-se em quatro eixos centrais, a saber:

Eixo ser-estar: Aponta para uma pedagogia do ser, no qual emergem aprendizagens, desde o nascimento, no âmbito das semelhanças e diferenças.

Eixo do pertencimento e da Participação: busca uma pedagogia dos laços na qual o reconhecimento da pertença à família é alargado progressivamente na direção da comunidade local e sua cultura.

Eixo experimentar e comunicar: define um caráter pedagógico experiencial onde a intencionalidade do fazer-experimentar é exercido em continuidade, interação, reflexão e comunicação constantes.

Dito isso, já se pode compreender a abordagem da Pedagogia-em-Participação do espaço enquanto lugar. Nas palavras de Oliveira-Formosinho (2011, p. 110),

Um espaço pedagógico que se caracteriza pelo poder educativo e comunicativo da estética, pelo poder ético do respeito por cada identidade pessoal e social, tornando porto seguro e amigável, abrindo-se ao lúdico e ao cultural.

O espaço assim concebido, para se efetivar, supõe dos professores a internalização do habitus de propiciar interações às crianças, uma vez que a tarefa de mediar a agência das crianças exige do adulto não é tarefa passível de solução por meio de fórmulas prontas. Os(as) professores(as) devem reconhecer que sua participação ativa nas experiências e na aprendizagem das crianças depende do contexto educativo e dos processos que ali se desenvolvem.

A documentação pedagógica também possui papel central, mas ela deve considerar tanto as crianças quanto os profissionais envolvidos, caracterizando-se assim como Documentação em Participação, o que implica documentar em parceria com meninas e meninos. Por meio desse importante instrumento é possível proporcionar a meta-aprendizagem de todos que constroem a Pedagogia-em-Participação (OLIVEIRAFORMOSINHO, 2007; 2011). 
É assim, um processo central para, através da triangulação interativa entre intenções, ações e realizações sustentar a práxis e promover o movimento triangular de (re)criação da pedagogia como ação fecundada na teoria e sustentada num sistema de crenças (OLIVEIRAFORMOSINHO, 2011, p. 117).

\subsection{O contexto do município de São Paulo: Currículo Integrado para a Primeira}

\section{Infância.}

Alguns esforços estão sendo empreendidos no município a fim de construir um currículo para a infância, rompendo a divisão em faixas etárias. Essa proposta considera importante, para atingir o objetivo de promover um atendimento baseado na pedagogia da infância, reconhecer que a infância não termina aos cinco anos e onze meses. Atualmente, a secretaria municipal de educação compreende que o currículo não é algo estático e sim um processo que se constrói, no tempo e espaço vivido, na relação entre crianças e adultos, na individualidade e na imprevisibilidade do cotidiano (SÃO PAULO, 2013). Desta forma, cabe às unidades de Educação Infantil organizar seus tempos, espaços e materiais, considerando meninos e meninas em sua integralidade,

[...] ou seja, que considere a criança como pessoa capaz, que tem direito de ser ouvida e de ser levada a sério em suas especificidades enquanto 'sujeito potente', socialmente competente, com direito à voz e à participação nas escolhas; como pessoa que consegue criar e recriar, "verter e subverter a ordem das coisas", refundar e ressignificar a história individual e social; como pessoa que vê o mundo com seus próprios olhos, levantando hipóteses, construindo relações, teorias e culturas infantis por meio da expressão e da manifestação nas diferentes linguagens e nos diferentes modos de agir, construindo seus saberes e (re)ensinando aos adultos a olhar o mundo com "olhos de criança" (SÃO PAULO, 2013, p. 5).

Nesse contexto, todos os profissionais da Educação Infantil devem ser considerados educadores que tanto cuidam quanto educam, contribuindo para a formação de meninas e meninos. Para tanto, é importante que esses atores tenham clareza do seu papel, agindo como um "observador participante", para que assim possam oferecer em cada circunstância o suporte necessário para as crianças avançarem em sua aprendizagem. Suas práticas, portanto, não devem se inspirar nos modelos do Ensino Fundamental, antes, necessitam estar pautadas nos princípios da Pedagogia da Infância, construída para e com as crianças e suas famílias (SÃO PAULO, 2013). 
De acordo com a Orientação Normativa n ${ }^{\circ} 1$ de 2013, são princípios da Pedagogia da Infância no município,

a) Considerar a criança como principal protagonista da ação educativa; b) A indissociabilidade do cuidar e do educar no fazer pedagógico; c) Considerar a criança como centro da atenção do Projeto Político Pedagógico; d) Possibilitar à criança o acesso aos bens culturais, construídos pela humanidade, considerando-as sujeito de direitos, portadora de história e construtora das culturas infantis; e) Reconhecer e valorizar a diversidade cultural das crianças e de suas famílias; f) Dar destaque ao brincar, a ludicidade e às expressões das crianças na prática pedagógica de construção de todas as dimensões humanas; g) Considerar a organização do espaço físico e tempo como um dos elementos fundamentais na construção dessa pedagogia; h) Efetivar propostas que promovam a autonomia e multiplicidade de experiências; i) Possibilitar a integração de diferentes idades entre os agrupamentos ou turmas; j) Ter a arte como fundamento na formação dos (os) profissionais da primeira etapa da Educação Básica; 1) Estabelecer parcerias de participação com as famílias; m) Estender o "espaço educativo" para a rua ou bairro e a cidade; n) Buscar continuidade educativa da Educação Infantil na direção do Ensino Fundamental (SÃO PAULO, 2013, p. 7).

Com base em tais princípios, os educadores da infância precisam, ao elaborar seu planejamento, reservar um espaço para que o inesperado se manifeste, permitindo às crianças a elaboração e construção de novos conhecimentos e teorias, lançando mão de instrumentos que deem conta da documentação de todo o processo.

O currículo integrador pretende efetivar propostas que promovam a autonomia e a multiplicidade de experiências, fomentando a integração de diferentes idades entre os agrupamentos ou turmas. Nesse sentido, a arte aparece como o fundamento na formação das profissionais da primeira etapa da Educação Básica. Além disso, a parceria e participação das famílias, o entendimento do bairro e da rua como espaço educativo, bem como a continuidade da Educação Infantil na direção do Ensino Fundamental, aparecem como fatores preponderantes nesse contexto (SÃO PAULO, 2013).

A participação da família na instituição é de extrema importância para o desenvolvimento das crianças e, sobretudo, para a promoção do trabalho democrático participativo, portanto há de se garantir condições para se realizar trocas, interações com outras pessoas, sejam crianças ou adultos. Essa participação efetiva contribui imensamente na medida em que informações são compartilhadas, aprendizagens são construídas e reconstruídas em contextos específicos - contextos estes que estão sempre abertos à mudança, tais como: cuidar e educar; do brincar; das diferentes infâncias; das marcas infantis em relação aos espaços; das interações e do social ampliado (SÃO PAULO, 2013, p. 14). 
O currículo integrador no contexto do município de São Paulo preconiza a Documentação Pedagógica como eixo central no seu desenvolvimento, tal documentação deve conter observações e registros rigorosos da realização das práticas, servindo também como instrumento de reflexão, avaliação e partilha com as famílias. Nesse sentido,

O educador poderá manter um caderno contendo fatos relativos a cada criança, individualmente. Além disso, existem, ainda, os registros construídos pelas próprias crianças, que devem ser considerados na elaboração de portfólios individuas e coletivos e também, ocupar lugar de material de análise e reflexão das professoras bem como de estudos nos horários e momentos formativos. Os portfólios individuais serão compostos de atividades desenvolvidas, além de falas das crianças, fotos, objetos, coleções, etc. Já os portfólios coletivos conterão as atividades realizadas em grupo pelas crianças, além de algumas observações próprias do educador, tais como: a participação de cada criança na atividade proposta, o surgimento de lideranças, os possíveis conflitos, etc. (SÃO PAULO, 2013, p.15).

Ao final da etapa da Educação Infantil, a documentação construída ao longo da trajetória de meninos e meninas deverá ser expedida por cada unidade, devendo ficar disponível para consulta no Ensino Fundamental. Com efeito, busca-se dessa forma um currículo que, para além de integrar Centros de Educação Infantil - CEI e Escolas Municipais de Educação Infantil - EMEI estabeleça um diálogo com as Escolas Municipais de Ensino Fundamental - EMEF.

Embora venham sendo empreendidos alguns esforços ao longo dos últimos anos, no contexto da prefeitura de São Paulo, na busca pela construção de uma matriz curricular comum para a Educação infantil, há Centros de Educação Infantil que caminham para a construção de modelos próprios e autônomos que deem conta de suas especificidades. O Centro de Educação Infantil em questão ${ }^{12}$, por meio da parceria com o grupo de pesquisa Contexto Integrados de Educação Infantil, busca a construção de uma Pedagogia-em-Participação. Nesse contexto, procura-se a reconceitualização dos principais protagonistas do processo educativo: professoras e crianças, considerandoos como sujeitos competentes e com direito à colaboração (OLIVEIRAFORMOSINHO, 2011). Essa reconceitualização, portanto, envolve um novo modo de pensar e fazer educação. É nesse sentido que parecem ir as palavras de Pinazza (2014, p. 53):

\footnotetext{
${ }^{12}$ Termo utilizado para fazer referência ao contexto em que se deu a pesquisa de campo.
} 
A esse modo de pensar e fazer a educação das crianças pequenas, que se revela em uma gramática pedagógica do currículo, corresponde uma perspectiva pedagógica congruente, para se pensar e fazer a educação dos adultos que atuam na educação e na educação infantil. Isso porque uma gramática (ou um modelo) não se encerra no campo dos preceitos filosóficos e teóricos. Sua concretização e sua evolução são garantidas pelos práticos.

Dito isso, é preciso esclarecer que esta pesquisa inspira-se no modelo curricular da Pedagogia-em-Participação na medida em que se propõe compreender as experiências vivenciadas no Centro de Educação Infantil ouvindo os diferentes atores que compõe esse espaço e observando os princípios democráticos presentes no interior das práticas pedagógicas. 


\section{CONTEXTO E CAMINHOS DA PESQUISA EMPÍRICA}

Neste capítulo, será apresentada a abordagem metodológica adotada na pesquisa como um todo e na produção de dados em particular, bem como será exposto o contexto investigado, com destaque ao agrupamento de crianças e às professoras tomadas em foco.

\subsection{Caminho metodológico}

Este estudo refere-se a uma pesquisa de natureza qualitativa. Como esclarecem Lankshear e Knobel (2008), a pesquisa qualitativa caracteriza-se, entre outros fatores, por sua forte dependência da coleta de informações sobre eventos e processos em contextos da vida real em que os pesquisadores intentam compreender o mundo a partir da perspectiva de outras pessoas.

Uma investigação qualitativa tem como fonte de dados o ambiente natural em que o pesquisador é o instrumento principal. Os dados são analisados de forma indutiva, sem a proposição de comprovar hipóteses prévias, e assumem grande importância por possibilitar uma maior compreensão do objeto de estudo. O interesse do investigador qualitativo centra-se, principalmente, no processo (BOGDAN; BIKLEN, 1999).

Trata-se de uma pesquisa pedagógica, uma vez que se volta, sobretudo, para as questões referentes às práticas que se dão em contexto escolar. Lankshear e Knobel (2008) afirmam que a pesquisa pedagógica pode ser realizada, entre outros espaços, em salas de aula e em programas acadêmicos oficiais. Vale lembrar que não se trata de professores pesquisando a sua própria prática em sala de aula, mas sim de uma pesquisa pertinente à própria prática profissional.

Nas palavras de Lankshear e Knobel (2008, p. 17):

Frequentemente conseguimos entender com mais clareza a nós mesmos e a nossa prática, crenças, suposições, valores, opiniões, visões de mundo e coisas assim, quando encontramos outros tão diferentes de nós, que põe em evidência as nossas características, colocando-as em perspectiva.

A pesquisa define-se como um estudo de caso único. O estudo de caso é apropriado em situações em que o caso é revelador, ou seja, permite acesso a 
informações que não são facilmente disponíveis (YIN, 2005). Tal estratégia se mostra a mais adequada quando se quer compreender "como" ou "por que" as coisas acontecem. Como afirma Yin (2005, p. 19):

\footnotetext{
Em geral, os estudos de caso representam a estratégia preferida quando se colocam questões do tipo "como" e "por que", quando o pesquisador tem pouco controle sobre os acontecimentos e quando o foco se encontra em fenômenos contemporâneos inseridos em algum contexto da vida real.
}

Tal como já foi exposto anteriormente, o presente estudo pretende compreender como se constitui a organização das práticas educativas partilhadas por duas duplas de professoras, na medida em que devem compor a rotina de um mesmo agrupamento de determinado Centro de Educação Infantil da rede pública direta do município de São Paulo. A pesquisa empírica foi desenvolvida durante o ano de 2013 e a análise dos dados produzidos pautou-se no conceito de experiência, com seus princípios definidores, continuidade e interação, tal como anunciados por Dewey (1980).

\subsection{Contexto da pesquisa}

A pesquisa empírica foi realizada de agosto a dezembro de 2013, num CEI localizado na Zona Oeste de São Paulo.O bairro chama-se Vila Antônio e possui, em seu entorno, alguns estabelecimentos comerciais, tais como: funilarias, oficinas mecânicas, casa de materiais para construção, autoelétrico, além de um grande número de residências. O bairro conta com recursos assistenciais, um Centro de Saúde e o Hospital Universitário, e está cercado por igrejas de vários credos, escolas públicas e particulares de diversos níveis, além de todo o patrimônio cultural da Universidade de São Paulo (USP) e do Centro Educacional Unificado (CEU) Butantã.

O CEI atende uma comunidade formada por moradores residentes nas proximidades da instituição e adjacências. Uma breve análise das fichas de matrícula revelou que a maioria das mães e pais possui entre 30 e 40 anos de idade, é oriunda das regiões Sudeste e Nordeste do país, e trabalha fora exercendo profissões como vigia, recepcionista, operador(a) de telemarketing, vendedor(a), mestre de obras, entre outras. Boa parte possui segundo grau completo.

O horário de funcionamento da instituição em foco compreende o período das 07h30min às $19 \mathrm{~h} 00 \mathrm{~min}$, sendo o atendimento das crianças realizado das 08h00min às 
18h00min. Atende crianças de 1 ano a 4 anos e 11 meses. Conta com duas salas de Berçário II, com 17 crianças, de 1 ano a 1 ano e 11 meses; duas salas de Mini Grupo I, com 24 e 33 crianças, de 2 anos a 2 anos e 11 meses; três salas de Mini Grupo II, com crianças de 3 anos a 3 anos e 11 meses, sendo uma delas com 15 crianças, por ter uma criança com necessidades educacionais especiais, e as demais com 20 crianças cada. É o que se vê na tabela 1.

Tabela 1 - Agrupamentos e salas do CEI

\begin{tabular}{|c|c|c|c|}
\hline \multirow{2}{*}{ TURMA } & IDADE DAS CRIANÇAS & $\begin{array}{c}\text { NÚMERO } \\
\text { DE SALAS }\end{array}$ & $\begin{array}{c}\text { TOTAL DE } \\
\text { CRIANÇAS } \\
\text { ATENDIDAS }\end{array}$ \\
\hline BERÇÁRIO II & 1 ANO A 1 ANO E 11 MESES & 2 & 34 \\
\hline MINI GRUPO I & 2 ANOS A 2 ANOS E 11 MESES & 2 & 57 \\
\hline MINI GRUPO II & 3 ANOS A 3 ANOS E 11 MESES & 2 & 35 \\
\hline
\end{tabular}

O prédio é composto por dois pavimentos. No piso superior, das quatro salas de atividades $^{13}$, duas possuem banheiros privativos. Há também um solário, um lactário, um banheiro comum que atende as outras duas salas, e um banheiro para funcionários. No piso térreo, existem três salas de atividades, um banheiro comum que atende essas salas, sala de professores, refeitório para as crianças, cozinha com despensa, lavanderia, quatro banheiros para funcionários (um deles adaptado para pessoas com necessidades especiais), recepção, direção, coordenação pedagógica, secretaria, dois almoxarifados e um elevador. A área externa possui um parque, uma quadra, um tanque de areia e estacionamento. As Fotografias a seguir pretendem unicamente ilustrar o espaço físico do CEI.

\footnotetext{
${ }^{13}$ Termo utilizado, nesta ocasião, para designar as salas de referência de cada agrupamento.
} 


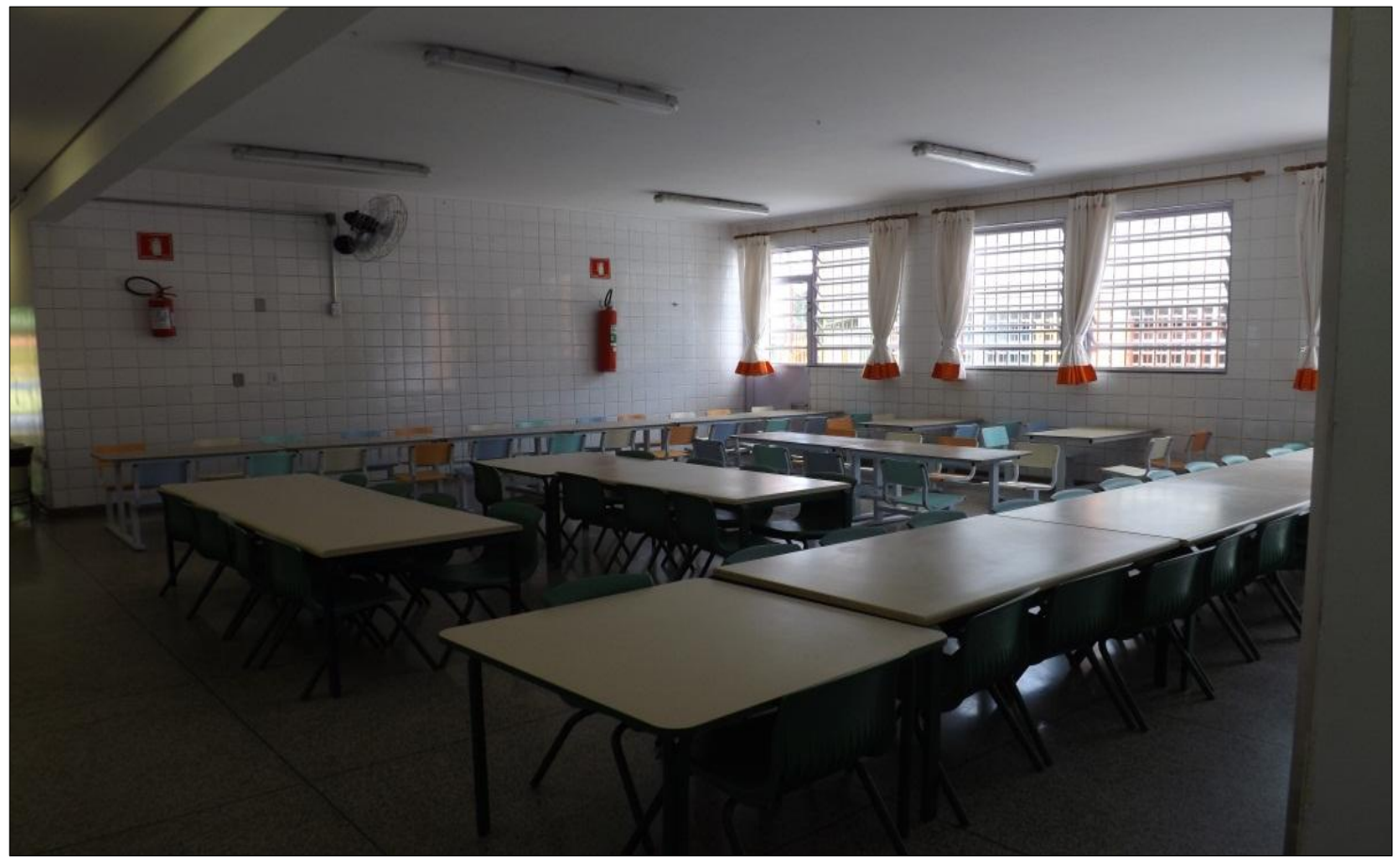

Fotografia 1 - Refeitório.

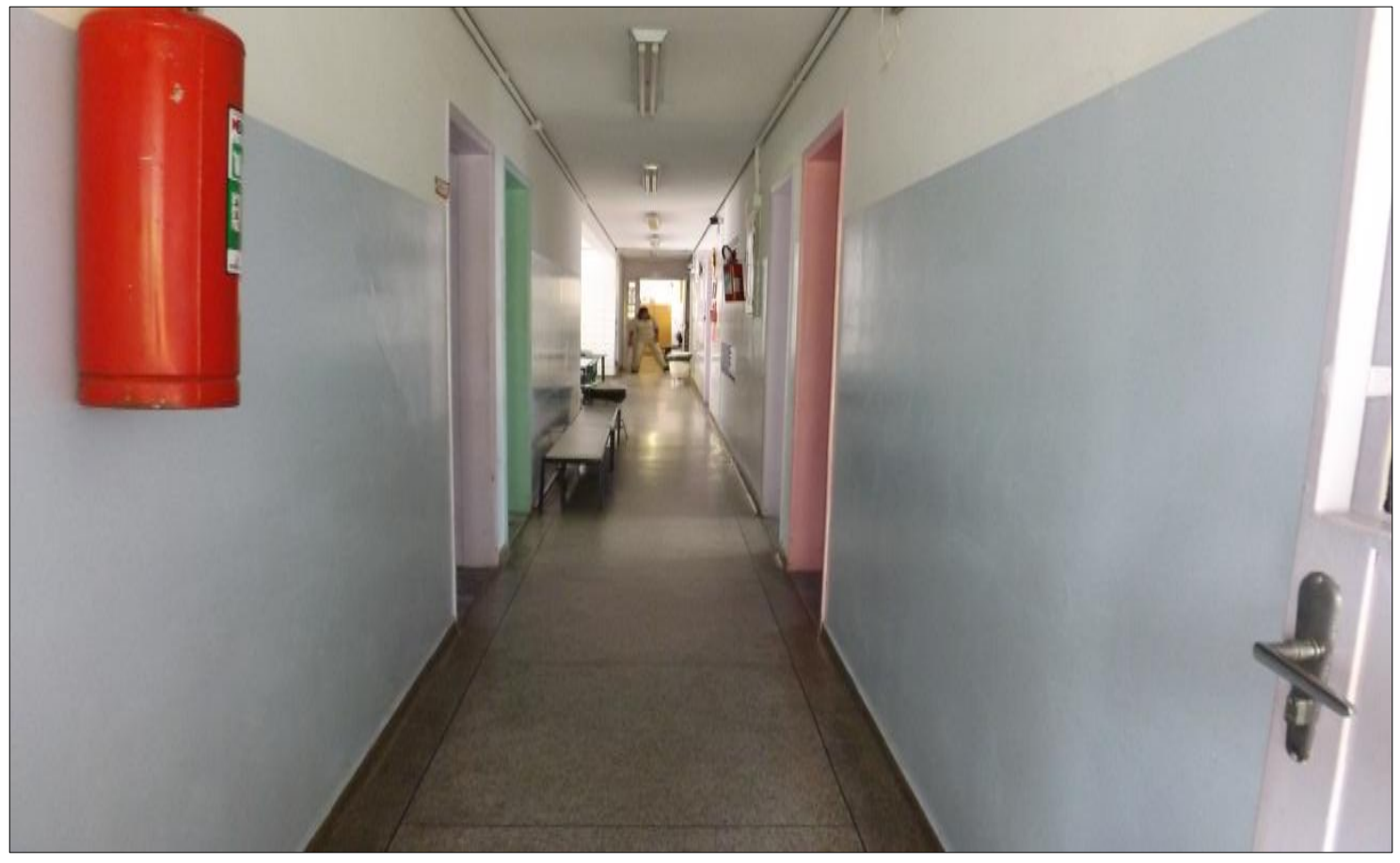

Fotografia 2 - Corredor de acesso às salas do pavimento inferior. 


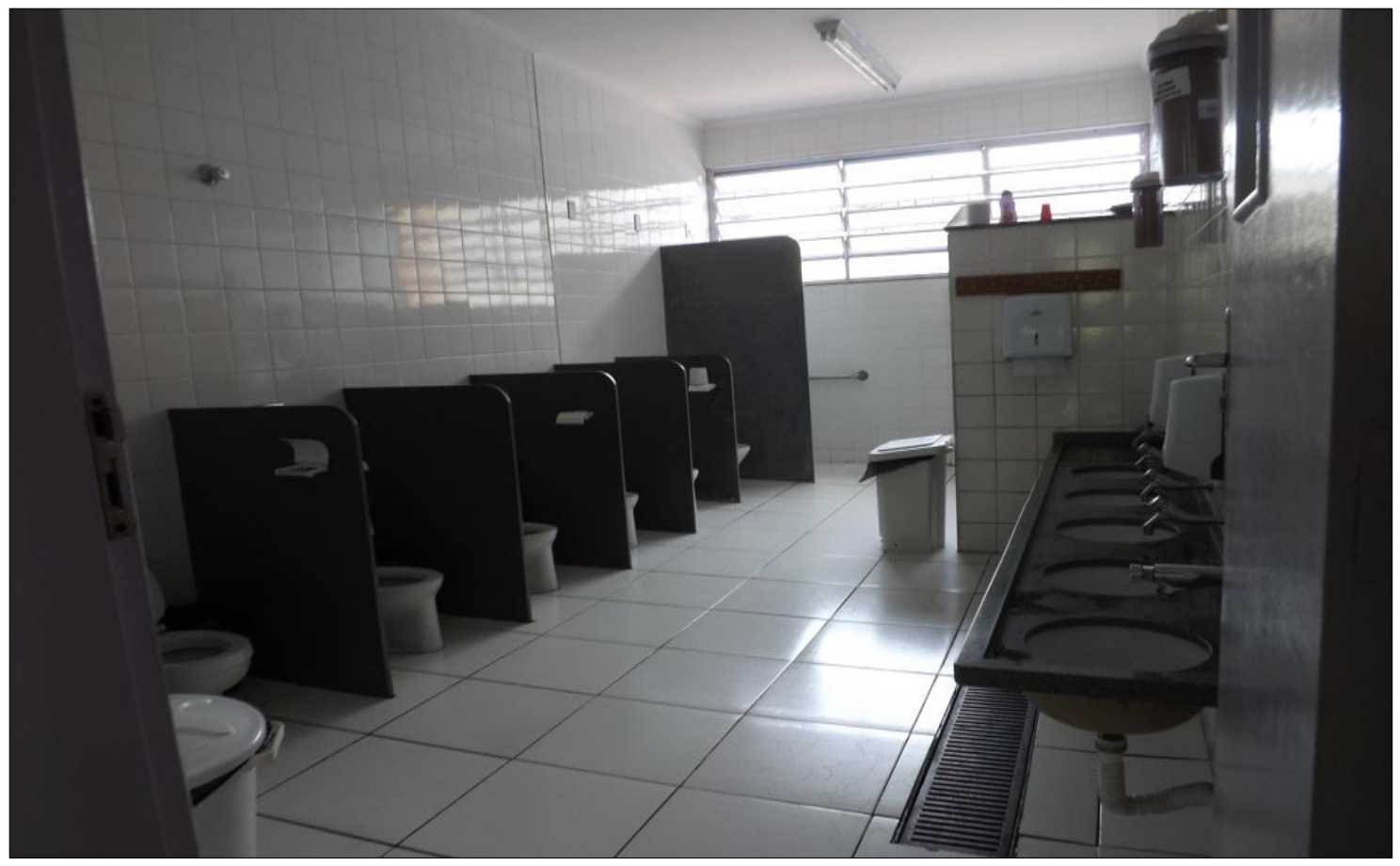

Fotografia 3 - Banheiro das crianças no pavimento inferior.

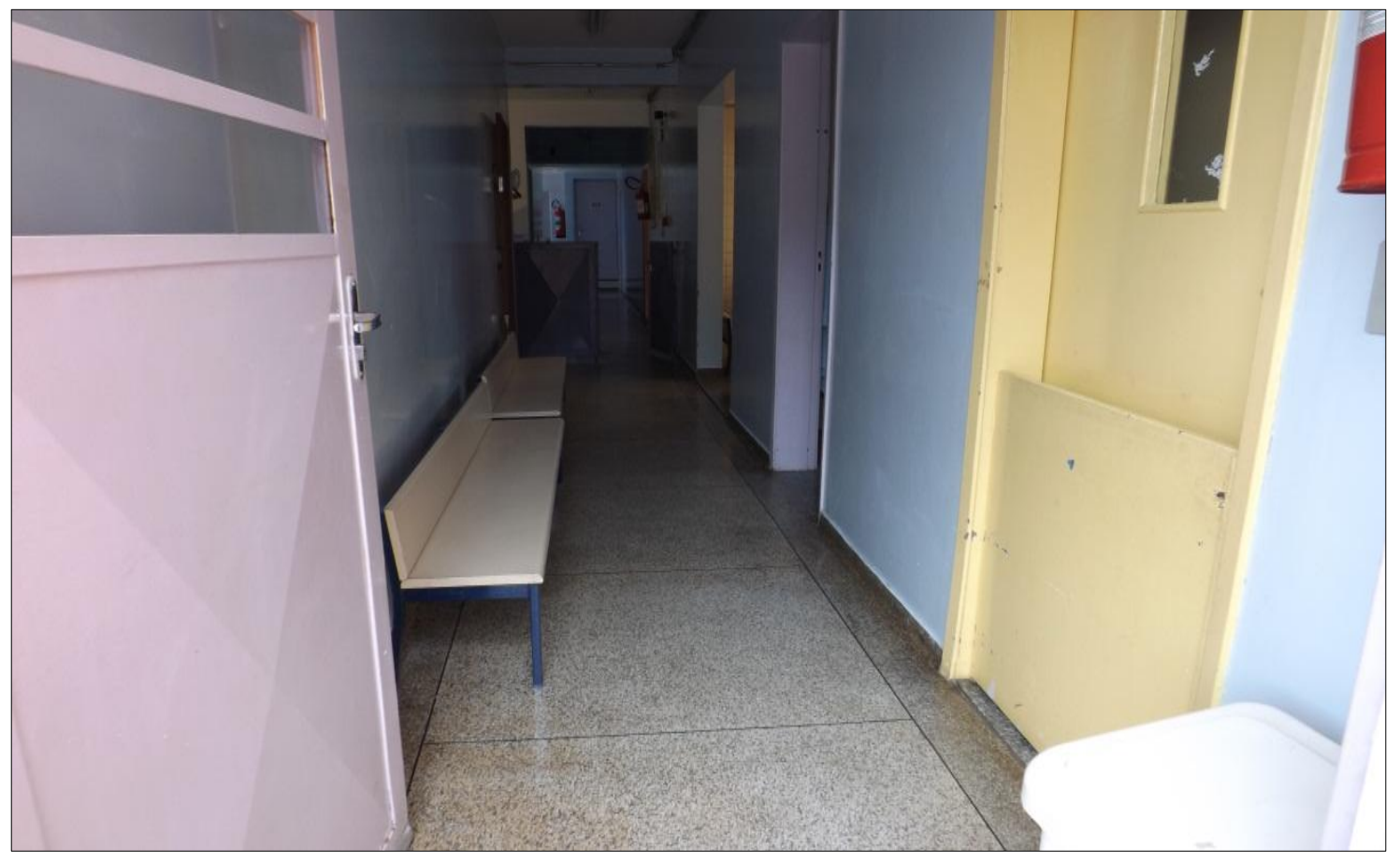

Fotografia 4 - Corredor de acesso às salas do pavimento superior. 


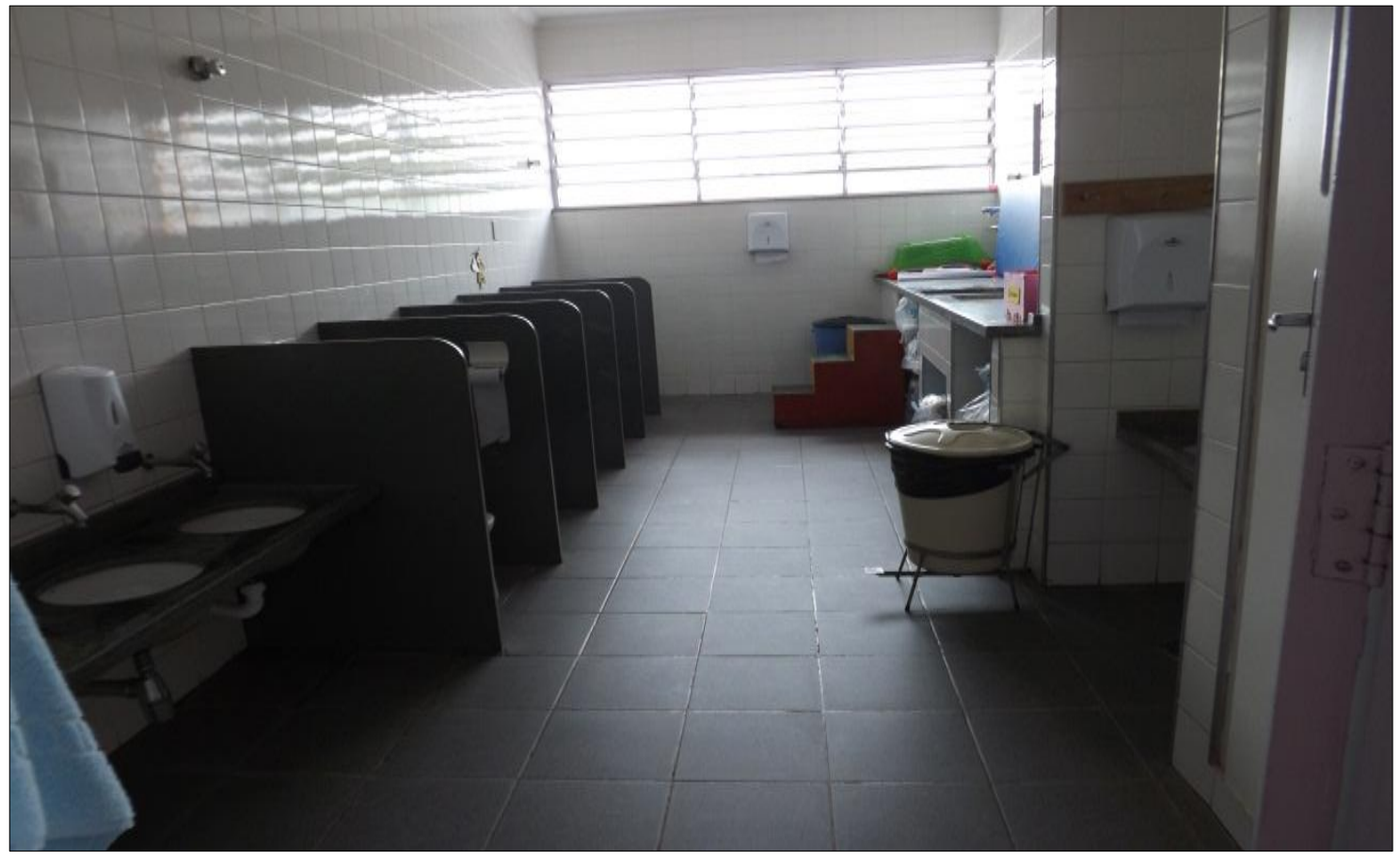

Fotografia 5 - Banheiro das crianças no pavimento superior.

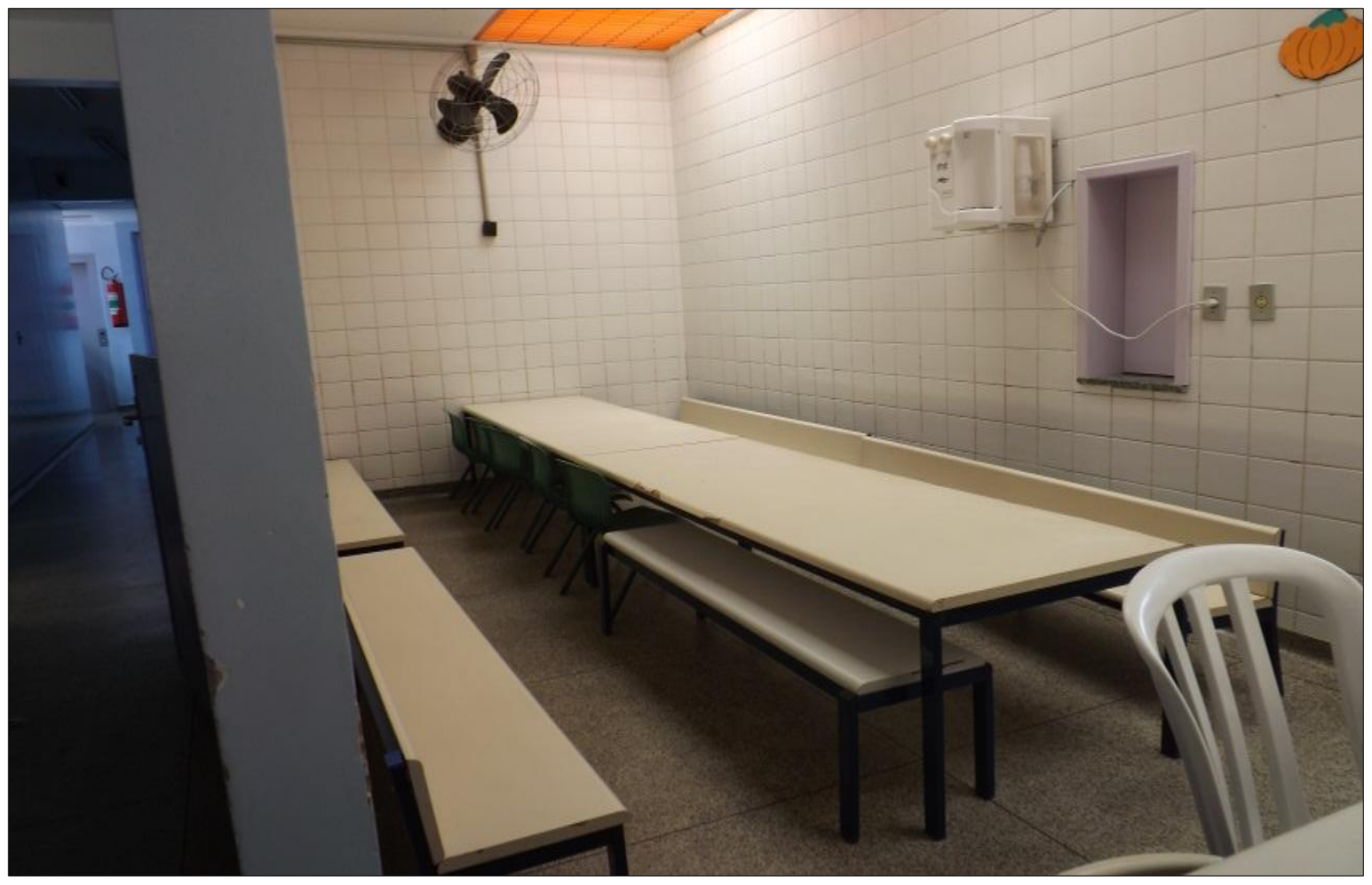

Fotografia 6 - Antigo lactário, atualmente utilizado para diferentes fins, entre eles atividades com as crianças. 


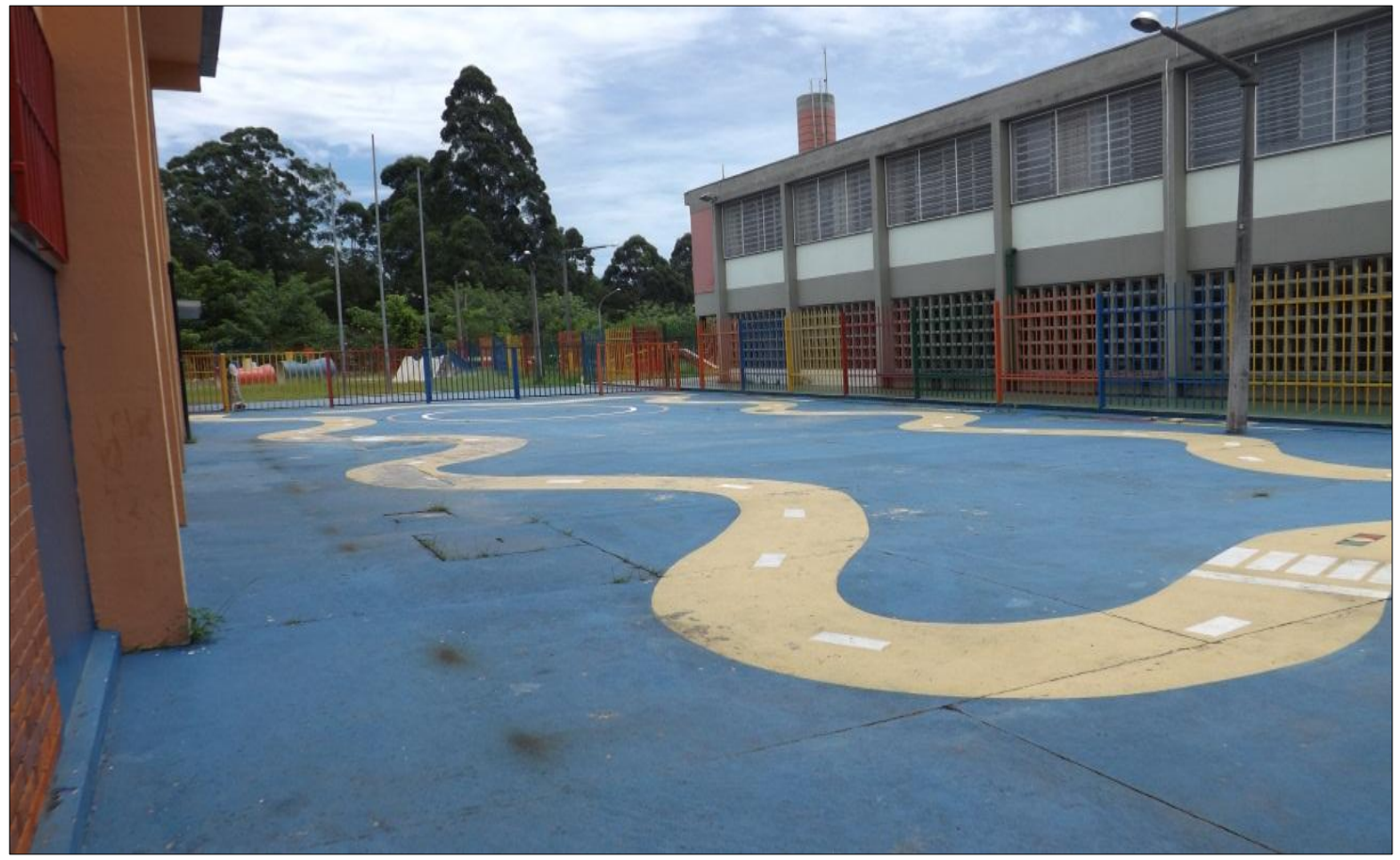

Fotografia 7 - Chamada "área azul” (área externa no pavimento inferior do CEI).

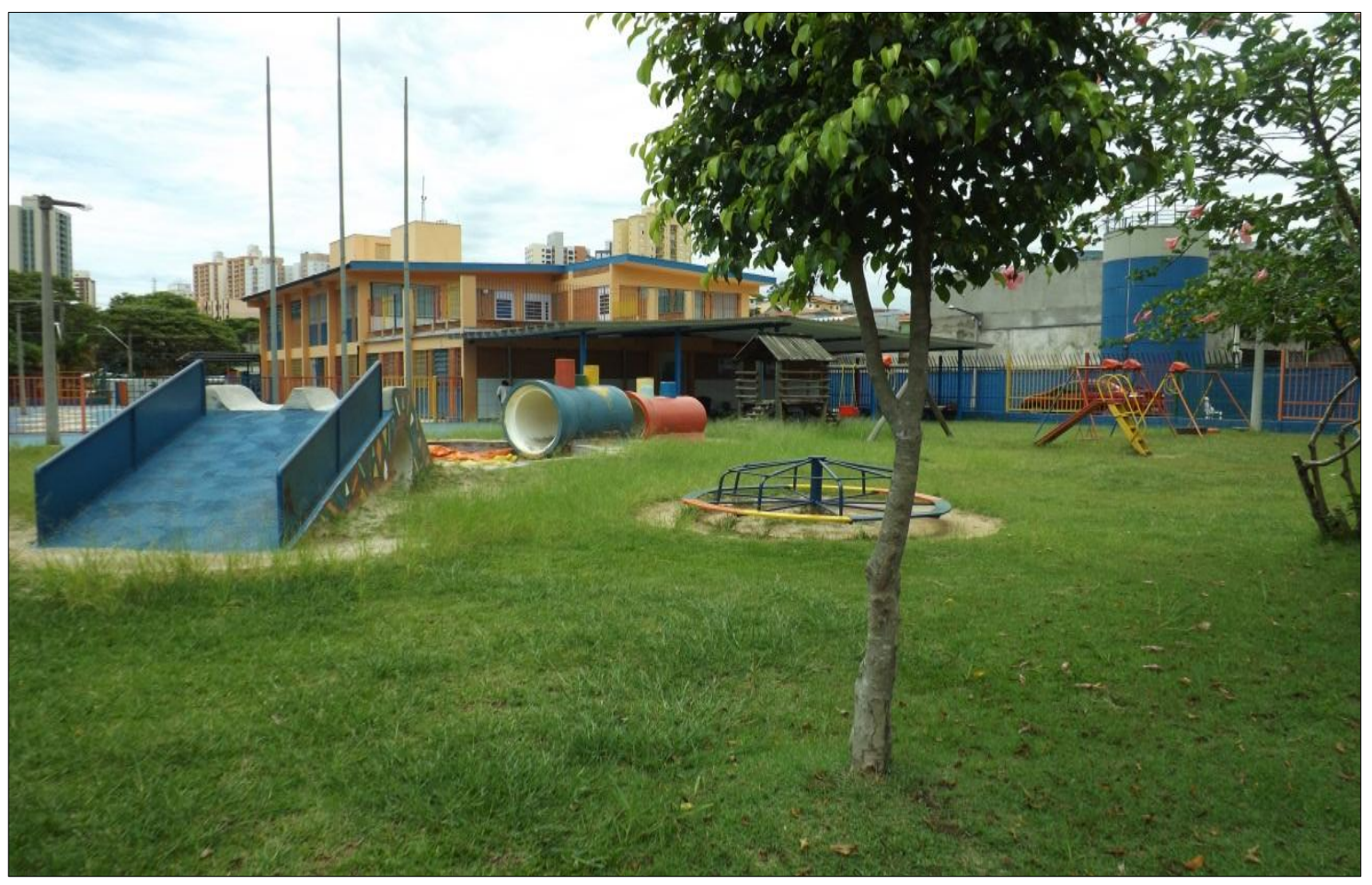

Fotografia 8 - Parque. 


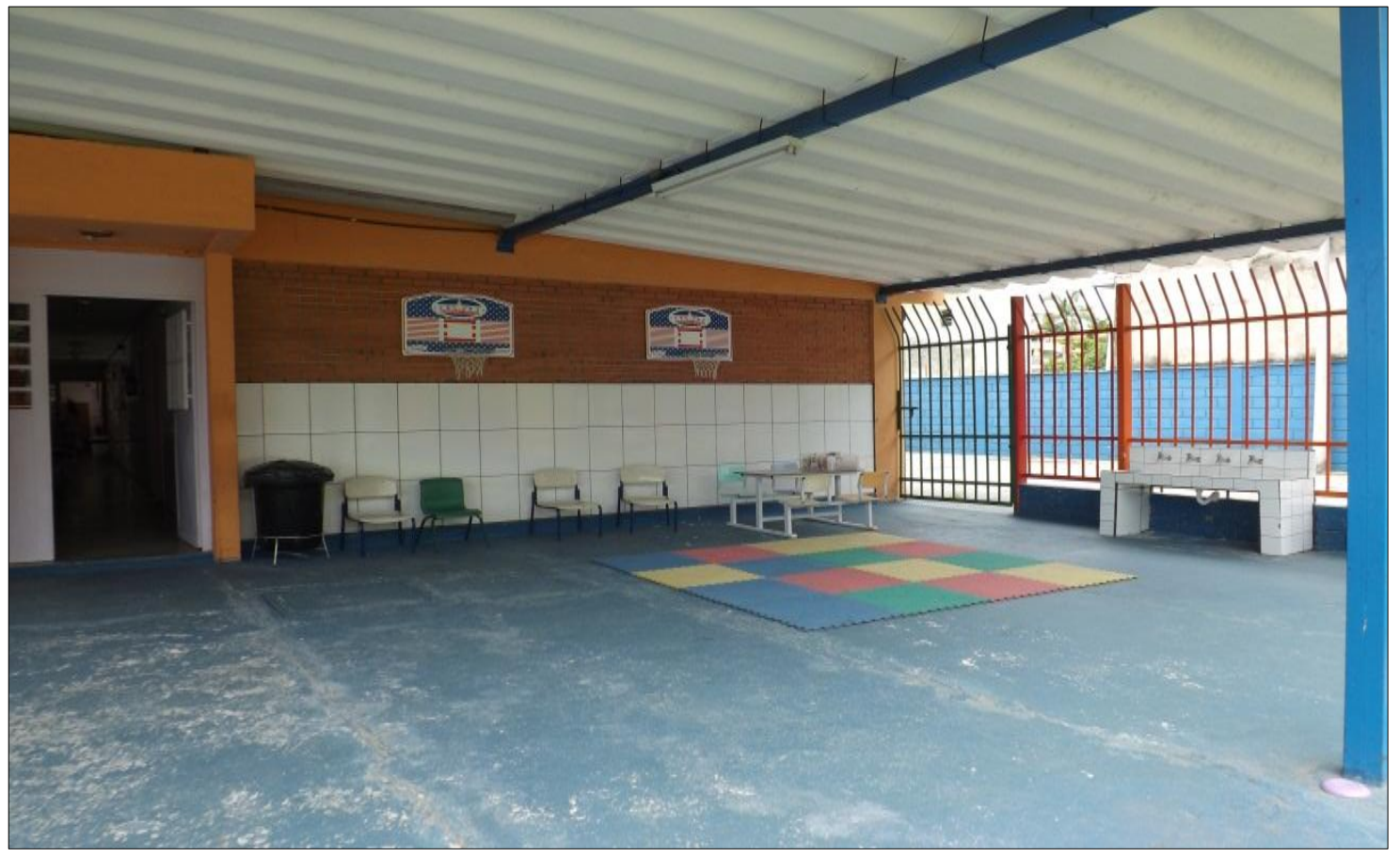

Fotografia 9 - Espaço no parque com torneiras, pia e parede azulejada para pintura.

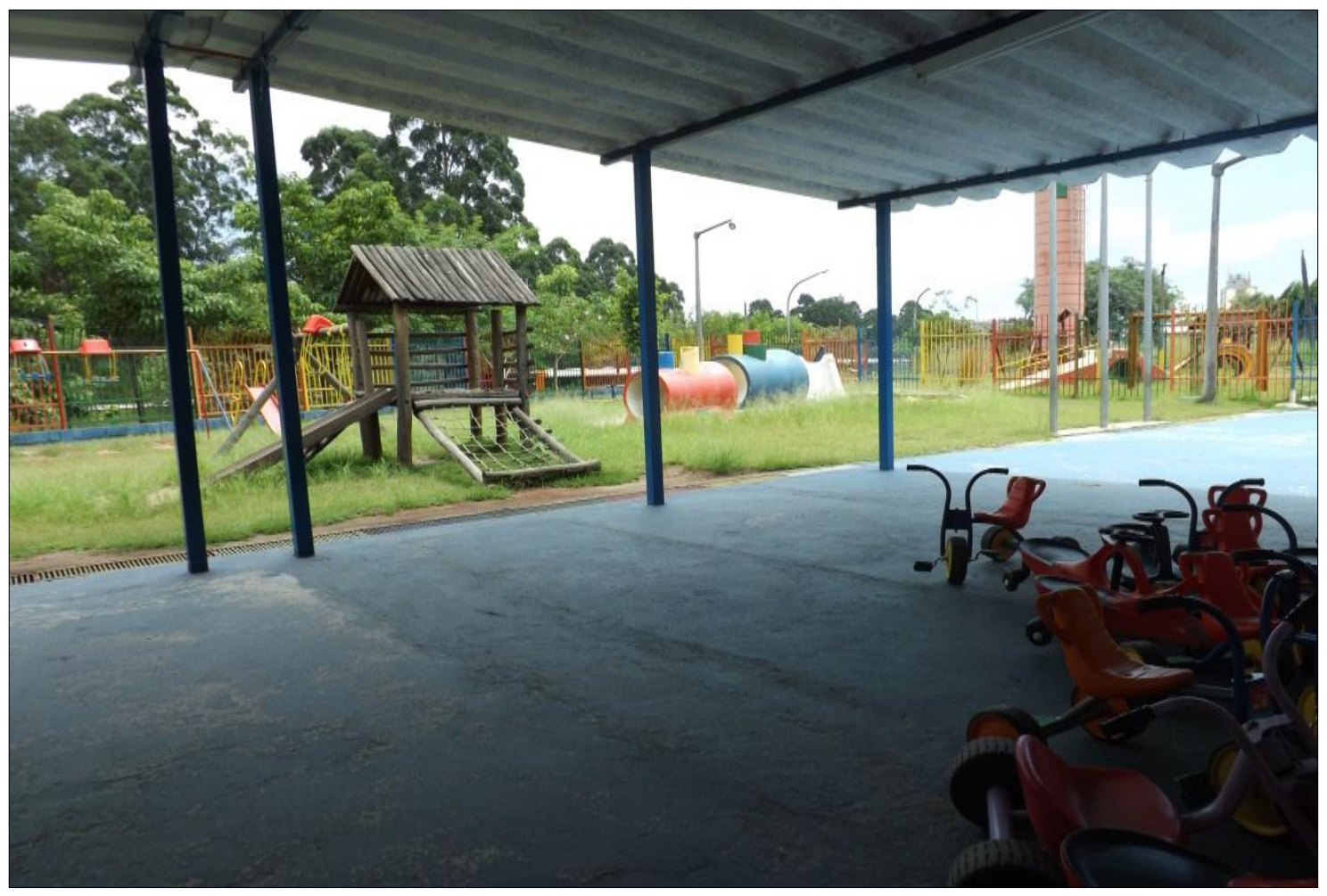

Fotografia 10 - Área coberta do parque. 


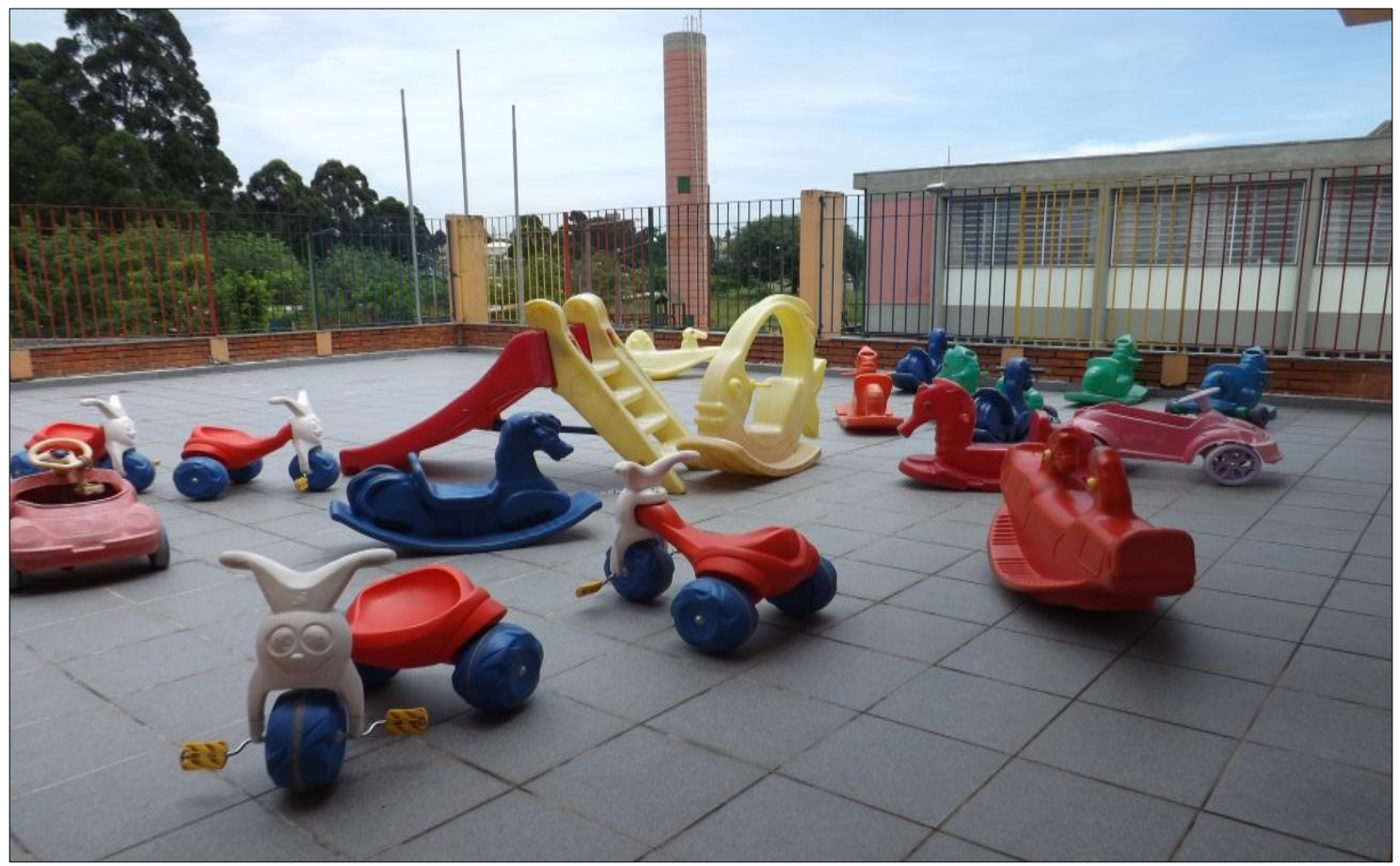

Fotografia 11 - Solário.

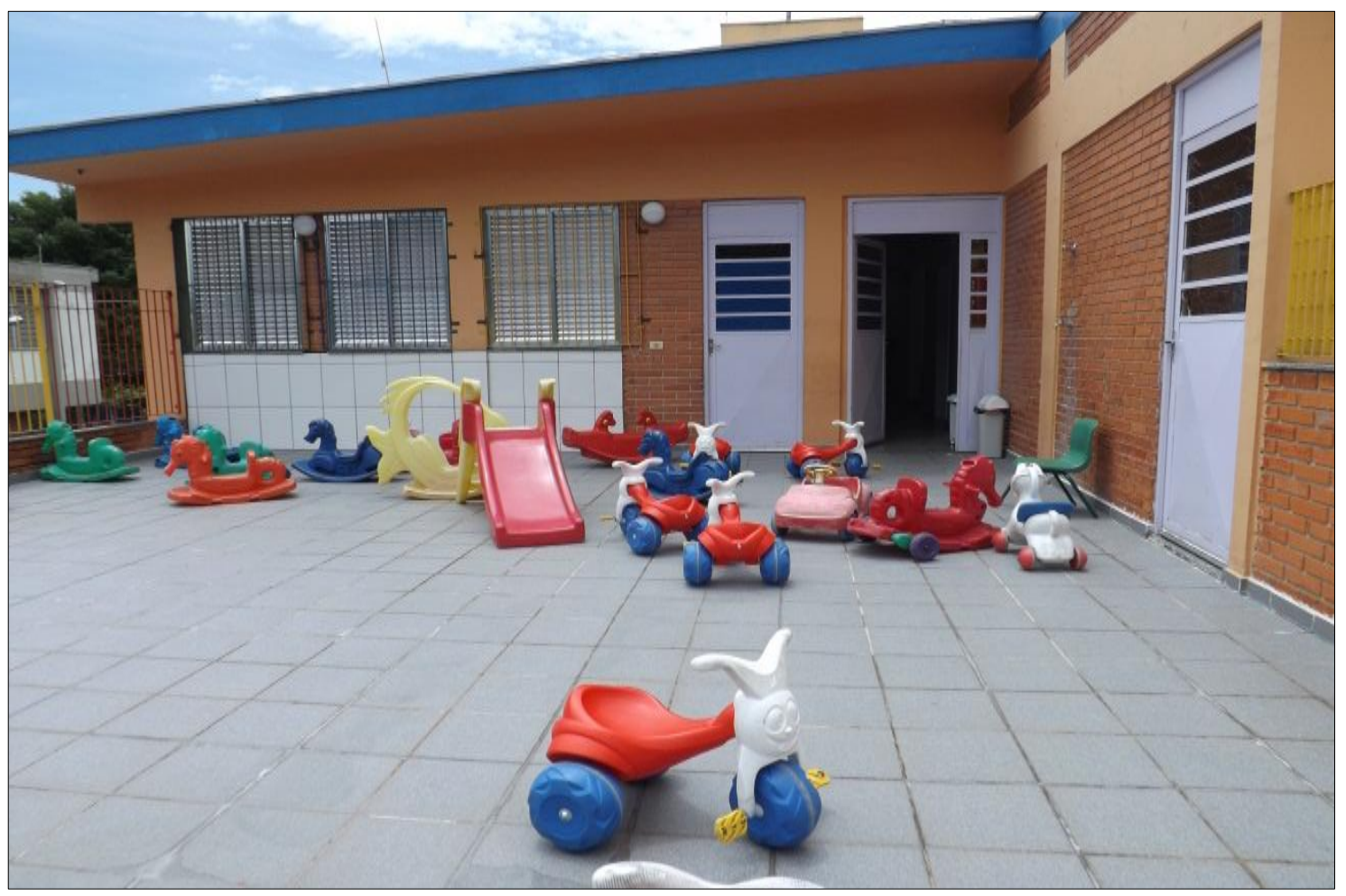

Fotografia 12 - Solário. 
A instituição conta com os equipamentos descritos na tabela 2:

Tabela 2 - Equipamentos do CEI

\begin{tabular}{|l|l|}
\hline \multicolumn{2}{|c|}{ EQUIPAMENTOS DO CEI } \\
\hline 03 & Aparelhos de TV \\
\hline 02 & Aparelhos de DVD \\
\hline 07 & Rádios gravadores (um para cada sala) \\
\hline 06 & Computadores (Secretaria, Diretoria, Coordenação, Sala dos Professores) \\
\hline 01 & Impressora a laser \\
\hline 01 & Aparelho de som micro system \\
\hline 01 & Aparelho de DVD Karaokê \\
\hline 01 & Máquina fotográfica digital \\
\hline 01 & Retroprojetor \\
\hline
\end{tabular}

Possui, além disso, um bom número de livros infantis, lanternas, materiais de horta, bolas, bambolês, fantasias, fantoches, tecidos, além de um número expressivo de brinquedos, entre eles: triciclos, bonecas e bonecos, jogos de encaixe diversos, jogos de memória, quebra-cabeças, panelinhas etc.

A unidade educacional conta, atualmente, com um corpo de funcionários composto por: uma diretora, uma coordenadora pedagógica, 25 professoras (dentre as quais uma é readaptada), cinco auxiliares técnico-administrativos e quatro agentes de apoio.

A sala do MGI-A ${ }^{14}$, turma em que se deu a pesquisa, era bem ampla, foi idealizada na verdade para atender berçário I, contudo como na unidade não havia grande demanda por berçário I, ela foi utilizada para atender MGI, o que favoreceu o grupo, uma vez que esse poderia desfrutar de um espaço maior do que o habitualmente cedido a essas turmas. A sala possuía em uma das paredes um armário com portas, embutido, quase da altura do pé direito, no qual as professoras guardavam seu material, e as crianças guardavam suas mochilas. Havia também, em outra parede, um móvel sem portas, dividido em três partes, onde eram guardados os colchonetes em que as crianças

\footnotetext{
${ }^{14}$ Mini-Grupo I-A ( nomenclatura utilizada no contexto do CEI para identificar as turmas)
} 
dormiam. Os lençóis utilizados para cobrir as crianças e os colchonetes eram guardados em capas plásticas individuais dentro do armário com portas. O lado direito da sala era organizado com os materiais e objetos que compunham as áreas de interesse: casinha, fantasia, construção, sorveteiro, médico, artes. Em outro canto, havia uma espécie de plástico com bolsos transparentes em que ficavam expostos livros infantis na altura das crianças. Nas paredes havia produções da turma, fotos, bem como o cartaz com o nome e a foto de cada criança utilizado para fazer a "chamadinha". O piso, próximo ao expositor de livros era coberto com tatames de EVA, que demarcavam a área da leitura e o espaço para a roda de conversa. Havia também um espelho bem grande que envolvia meia parede da sala. Em uma mesa, havia um aquário com um peixinho doado pela família de uma criança da turma.

Os critérios utilizados para a escolha da instituição foram: a parceria entre o CEI e o grupo de pesquisa Contextos Integrados de Educação Infantil da Faculdade de Educação da Universidade de São Paulo, bem como a disponibilidade da unidade em colaborar com a investigação. Para a escolha do agrupamento, os principais fatores considerados foram: a disponibilidade das professoras para colaborar com a pesquisa e a assiduidade delas.

Estabelecido o processo colaborativo, o passo seguinte foi conhecer a instituição e as professoras. As duas primeiras visitas ao CEI tiveram o propósito de estabelecer os primeiros contatos e proceder às apresentações pessoais. Houve uma recepção bastante positiva, tanto por parte das professoras como das gestoras. Na ocasião, a pesquisadora foi apresentada pela coordenadora pedagógica a todos os funcionários e funcionárias. Foram também apresentados os espaços e a proposta pedagógica da instituição. A receptividade do primeiro contato preservou-se nas demais visitas. Nas aproximações iniciais, foi apresentada a proposta da investigação empírica acompanhada das cartas de autorização para a sua realização junto às quatro professoras e à equipe gestora do $\mathrm{CEI}^{15}$.

O grupo acompanhado era formado por 24 crianças, sendo nove meninas e 15 meninos com idades entre 2 anos e 2 anos e 11 meses,conforme a tabela 3.

Tabela 3 - Idades e sexo das crianças do agrupamento

\footnotetext{
${ }^{15}$ Cf. Anexos de A a E.
} 


\begin{tabular}{|c|c|c|c|}
\hline TURMA & IDADE DAS CRIANÇAS & SEXO FEMININO & SEXO MASCULINO \\
\hline $\begin{array}{c}\text { MINI GRUPO } \\
\text { I }\end{array}$ & $\begin{array}{c}\text { 2 ANOS A 2 ANOS E 11 } \\
\text { MESES }\end{array}$ & 09 & 15 \\
\hline
\end{tabular}

Dois desses meninos realizam uma jornada opcional de meio período, entrando na creche somente às $13 \mathrm{~h} 00 \mathrm{~min}$. $\mathrm{O}$ agrupamento conta também com quatro professoras, duas delas atuantes no período da manhã, que compreende o horário das 07h00min às 13h00min, e outras duas no período da tarde, que se estende das 13h00min às $19 \mathrm{~h} 00 \mathrm{~min}$.

Tabela 4 - Horário das professoras

\begin{tabular}{|c|c|}
\hline $\begin{array}{c}\text { HORÁRIO DA MANHÃ } \\
\text { DAS 7h00 ÀS } 13 \mathrm{~h} 00\end{array}$ & 2 PROFESSORAS \\
\hline HORÁRIO DA TARDE & 2 PROFESSORAS \\
\hline DAS 13h00 ÀS $19 \mathrm{~h} 00$ & \\
\hline
\end{tabular}

As professoras envolvidas possuem formação em Pedagogia e atuavam na educação infantil mesmo antes de ingressar na Prefeitura de São Paulo. Dentre elas, duas “dobram período", isto é, realizam dupla jornada: uma delas o faz no município de São Paulo; a outra, no município de Cotia. Todas estão na mesma unidade há mais de quatro anos. As professoras participantes serão assim identificadas: P e V, dupla da manhã; e O e I, dupla da tarde.

P tem 48 anos, é de São Paulo, e possui formação em Pedagogia, com PósGraduação (lato sensu) em Psicopedagogia e Ciências na Educação Básica. Foi coordenadora de uma creche conveniada no período em que as "pajens" eram as profissionais que lidavam diretamente com as crianças. Ingressou na Prefeitura Municipal de São Paulo em 1992 como professora de ensino fundamental. Exonerou-se do cargo para morar em outro estado e, ao regressar a São Paulo em 2003, prestou o primeiro concurso para Professor de Desenvolvimento Infantil, em 2004, iniciando sua atuação no CEI, onde trabalha exclusivamente até hoje.

A professora $V$ tem 37 anos e é graduada em Pedagogia. Iniciou a carreira na rede particular como auxiliar de coordenação, depois foi promovida como professora na 
mesma escola. Ingressou na Prefeitura Municipal de São Paulo no ano de 2000, atuando como professora no ensino fundamental. No ano de 2004, ingressou como professora de CEI, acumulando os cargos. Atualmente, atua em uma EMEI e no CEI, ambos pertencentes à Secretaria Municipal de Educação de São Paulo. Trabalha no CEI desde que ingressou no cargo de Professora de Desenvolvimento Infantil (atualmente, Professor de Educação Infantil).

O tem 30 anos e possui graduação em Pedagogia com Pós- Graduação (lato sensu) em Psicopedagogia. Atuou durante sete anos como professora no Ensino Fundamental em um colégio particular e também nas Prefeituras de Osasco e Taboão da Serra. Ingressou na Prefeitura Municipal de São Paulo no ano de 2004 como Professora de Desenvolvimento Infantil, e há sete anos desenvolve seu trabalho como professora na instituição em questão.

A professora I, de 41 anos, cursou inicialmente o magistério. No ano de 2008, concluiu o Normal Superior no programa de formação PEC (Programa de Educação Continuada - Professores e professoras da rede pública municipal). Trabalha, atualmente, na Prefeitura Municipal de Cotia e na Prefeitura Municipal de São Paulo. Em Cotia, já atuou na educação infantil de Berçário (1 ano a 1 ano e 11 meses) até Jardim II (crianças de 5 anos a 5 anos e 11 meses) e, hoje, está com uma sala de crianças com necessidades educacionais especiais (deficientes mentais e deficientes físicos), em instituição especializada. Na Prefeitura Municipal de São Paulo, ingressou no ano de 2006, atuando em um CEI. Há cinco anos é professora no CEI em que a pesquisa foi realizada.

Tabela 5 - IDENTIDADE PESSOAL DAS PROFESSORAS

\begin{tabular}{|c|c|c|}
\hline NOME & IDADE & ESTADO CIVIL \\
\hline $\mathrm{P}$ & 48 & CASADA \\
\hline $\mathrm{V}$ & 37 & CASADA \\
\hline $\mathrm{O}$ & 30 & SOLTEIRA \\
\hline $\mathrm{I}$ & 41 & CASADA \\
\hline
\end{tabular}




\begin{tabular}{|c|c|c|c|c|}
\hline $\begin{array}{c}\text { NOM } \\
\text { E }\end{array}$ & FORMAÇÃO & $\begin{array}{c}\text { TEMPO DE } \\
\text { EXPERIÊNCIA } \\
\text { PROFISSIONA } \\
\text { L }\end{array}$ & $\begin{array}{c}\text { EXPERIÊNCIA } \\
\text { PROFISSIONA } \\
\text { L ANTERIOR }\end{array}$ & $\begin{array}{c}\text { TEMPO DE } \\
\text { EXPERIÊNCI } \\
\text { A NO CEI }\end{array}$ \\
\hline$P$ & $\begin{array}{c}\text { PEDAGOGA } \\
\text { PÓS } \\
\text { GRADUAÇÃO } \\
\text { LATO SENSU EM } \\
\text { PSICOPEDAGOGI } \\
\text { A E CIÊNCIAS NA } \\
\text { EDUCAÇÃO } \\
\text { BÁSICA }\end{array}$ & 21 ANOS & $\begin{array}{c}\text { PROFESSORA DE } \\
\text { ENSINO } \\
\text { FUNDAMENTAL-I } \\
\text { E } \\
\text { COORDENADORA } \\
\text { DE CEI DA REDE } \\
\text { INDIRETA - } \\
\text { PREFEITURA DE } \\
\text { SÃO PAULO }\end{array}$ & 09 ANOS \\
\hline $\mathrm{V}$ & PEDAGOGA & 13 ANOS & $\begin{array}{c}\text { AUXILIAR DE } \\
\text { COORDENAÇÃO E } \\
\text { PROFESSORA NA } \\
\text { REDE } \\
\text { PARTICULAR }\end{array}$ & 09 ANOS \\
\hline $\mathrm{O}$ & $\begin{array}{c}\text { PEDAGOGA COM } \\
\text { PÓS } \\
\text { GRADUAÇÃO } \\
\text { LATO SENSU EM } \\
\text { PSICOPEDAGOGI } \\
\text { A }\end{array}$ & 14 ANOS & $\begin{array}{l}\text { PROFESSORA DE } \\
\text { ENSINO } \\
\text { FUNDAMENTAL I }\end{array}$ & 07 ANOS \\
\hline I & $\begin{array}{c}\text { MAGISTÉRIO E } \\
\text { NORMAL } \\
\text { SUPERIOR }\end{array}$ & 14 ANOS & $\begin{array}{c}\text { PROFESSORA DE } \\
\text { EDUCAÇÃO } \\
\text { INFANTIL NO } \\
\text { MUNICÍPIO DE } \\
\text { COTIA - SP }\end{array}$ & 05 ANOS \\
\hline
\end{tabular}

Trata-se, portanto, de professoras mulheres com idade entre 30 a 48 anos, cuja experiência no CEI vária entre 5 e 9 anos. No que tange à formação, as três profissionais são pedagogas, uma possui magistério e normal superior, formação que constituía o requisito mínimo à época do primeiro concurso para PDI (Professora de Desenvolvimento Infantil). Essa regra permanece vigente atualmente, regulando os ingressos de professoras na rede municipal, seja no Ensino Fundamental I ou na Educação Infantil. 


\subsection{Produção de dados}

Para a produção de dados, foram utilizados os seguintes instrumentos e técnicas: análise documental e observações com registros escritos e fotográficos, bem como entrevistas semiestruturadas com as professoras envolvidas na pesquisa e as gestoras, coordenadora pedagógica e diretora. Numa primeira etapa, os registros aconteceram somente em bloco de notas, com registros escritos resultantes de observações diretas, no "calor do momento" (LANKSHEAR; KNOBEL, 2008).

As observações ocorreram durante visitas semanais à instituição, realizadas em dias alternados. As sessões iniciais estendiam-se ao longo do dia, com o intuito de captar elementos gerais da rotina desenvolvida pelas duplas de professoras. Passado um tempo, uma vez percebida a dinâmica do trabalho, estabeleceram-se focos de observações. Durante as primeiras visitas, foram acompanhados todos os momentos da rotina. Nas visitas subsequentes, buscou-se estabelecer alguns critérios para observação com base nos dados já coletados e no semanário das professoras. Dessa forma, em uma semana, focalizavam-se os momentos de higiene, alimentação e brincar livre nas áreas externas. Em outra, focalizavam-se os momentos envolvendo o brincar livre nas áreas internas do CEI e aqueles momentos dirigidos pelas professoras, como as rodas de conversa, por exemplo.

Foi realizado um total de 12 sessões de observação, que se estendiam ao longo de todo o dia. No decorrer do processo, percebeu-se a necessidade de registros fotográficos que pudessem favorecer a compreensão dos acontecimentos e enriquecer os registros escritos.

As entrevistas semiestruturadas eram individuais, realizadas em dias alternados com as quatro professoras do agrupamento, com a coordenadora pedagógica e com a diretora, foram registradas em gravação por áudio, mediante autorização prévia das pessoas entrevistadas, e conduzidas com base em roteiros previamente elaborados ${ }^{16}$. Esse tipo de entrevista permite aos pesquisadores comparar prontamente respostas diferentes à mesma questão e, ao mesmo tempo, permanecer abertos a pontos de discussão importantes e não previstos (LANKSHEAR; KNOBEL, 2008).

Por se tratar de um estudo de caso, a análise documental visou essencialmente a corroborar as evidências oriundas de outras fontes (YIN, 2005). Examinaram-se

\footnotetext{
${ }^{16}$ Cf. Apêndices A, H e J.
} 
documentos produzidos pelo CEI: projeto pedagógico (em que consta também o plano de formação da unidade), planos de trabalho e registros das professoras.

A familiaridade da pesquisadora com o contexto de pesquisa, junto à receptividade das professoras desde as primeiras sessões, permitiu que a observação ocorresse com participação. Lankshear e Knobel (2008) entendem que os professorespesquisadores têm uma vantagem quando o assunto é observação participante, uma vez que eles são, via de regra, participantes plenos da vida e das práticas escolares cotidianas. A observação participante pode ser definida como aquela em que o pesquisador se envolve direta e completamente com o contexto que está investigando.

\subsection{A triangulação de fontes de dados}

A natureza da pesquisa exigiu a triangulação das fontes de dados. De acordo com Yin (2005), o estudo de caso baseia-se em várias fontes de evidências, cujos dados precisam convergir em um formato de triângulo.

De acordo com Goméz, Flores e Jimènez (1996), a triangulação permite ao pesquisador integrar e contrastar todas as informações disponíveis para construir uma visão global, exaustiva e detalhada de cada experiência particular. Nesse sentido, os dados coletados através da observação serão confrontados com dados advindos de outras fontes, possibilitando uma compreensão menos subjetiva do problema de pesquisa. Na perspectiva se $\operatorname{Stake}^{17}$ (1999 apud FESTA, 2008), a triangulação surge da necessidade de estratégias de pesquisa irem além de simples intuições. Ademais, a triangulação serve para elevar o crédito da interpretação e alcançar a necessária confirmação da análise realizada.

O desenvolvimento de categorias de análise foi desencadeado, como dizem Lankshear e Knobel (2008), junto com a emergência dos dados. Dessa forma, os dados coletados considerados importantes foram agrupados em categorias definidas de forma indutiva, a fim de aprofundar a compreensão da questão pesquisada (BOGDAN; BIKLEN, 1999).

Como dito anteriormente, a análise e discussão dos dados produzidos será realizada à luz do conceito deweyano de experiência. Segundo Dewey, para que a experiência significativa seja uma forma de promoção da vida democrática e coletiva, deve obedecer a dois princípios: de continuidade, uma experiência de valor é a que

\footnotetext{
${ }^{17}$ STAKE, R. E. Investigación com estúdios de casos. 2 ed. Madrid: Ediciones Morata, S. L., 1999
} 
engendra outras experiências; e de interação, uma experiência não acontece no vazio, mas sim imersa em um contexto particular (PINAZZA, 2007; 2014).

De acordo com Pinazza (2014), Dewey elabora um conceito de experiência pela ótica do processo científico do conhecimento. Nas palavras da pesquisadora:

A experiência não é simples sensação, fruto do contato com os objetos, com seus atributos isoladamente, uma vez que não recebemos passivamente as impressões dos objetos. Pelo contrário, as experiências se efetivam pelas relações que as pessoas estabelecem com os objetos e seus atributos em um processo de discriminações e identificações por meio da experimentação (Ibid., p.27).

Não há, portanto, experiência sem interação. A experiência que resulta numa aprendizagem significativa supõe o estabelecimento de relações com os objetos, espaços e pessoas. Para além da interação, uma boa experiência precisa desenvolver o pensar reflexivo. De acordo com Dewey (1980), nossa experiência é reflexiva quando nos debruçamos sobre o antes e o depois do processo de aquisição de conhecimentos. A aprendizagem, uma vez vinculada à experiência, torna-se um processo contínuo. Neste sentido, Dewey (1933) pondera que é preciso verificar no acervo da experiência das crianças, o que será utilizável. Que foi que já aprenderam que possam auxiliar? Quais as comparações a fazer? Quais usos permitem fixar e esclarecer a compreensão do que já vivenciaram?

$\mathrm{Na}$ concepção de Dewey, a experiência permite ao humano conhecer e dar significado ao conhecido e, por isso, não poderia ocorrer de forma isolada.

Todo conhecimento, toda a ciência tem, assim, em mira, aprender a significação dos objetos e acontecimentos e este processo consiste sempre em torná-los fora de seu aparente isolamento, como coisas a parte , como porções de algum todo mais amplo sugeridos por eles, o qual por sua vez, os explicitará, dar-lhes-á razão de ser, isto é, tornálos-á significativos (DEWEY, 1933, p.146)

Dewey (1980) aponta a necessidade de conceber a experiência educativa em todo o seu significado social, o que implica tomá-la como exemplo dos processos por meio do qual a sociedade perdura. Isso significa oferecer recursos para que meninas e meninos possam familiarizar-se tanto com as necessidades primordiais da vida em sociedade quanto com os métodos que a crescente perspicácia e engenho humanos encontrou para satisfazê-las, de maneira que a própria instituição educacional se assuma como lócus da vida ativa, ao invés de um local isolado onde aprende-se de forma fragmentada. 
A este acolhimento dos processos sociais no bojo da instituição educativa, somase o reconhecimento da criança como centro da ação educativa. Dewey afirma (1980, p.140) que "a criança é o ponto de partida, o centro e o fim. Seu desenvolvimento, o ideal”. E, noutra passagem, acrescenta:

\begin{abstract}
A atividade educativa não se processa no vácuo, independentemente do objeto ou condições. Ao contrário, ela é sempre a resposta a estímulos específicos ou gerais, nascidos do próprio organismo ou do meio ambiente em que o indivíduo vive (Ibid., p.119)
\end{abstract}

De acordo com Dewey, uma experiência pode surgir do próprio cotidiano, pois o meio em que as crianças convivem já oferece subsídios para a curiosidade e para a observação. Nesse sentido, a curiosidade da criança é fator preponderante para que a experiência ganhe sentido. É essa inquietação e curiosidade que, segundo Dewey (1933, p. 253), dá todo o sentido à experiência e motiva a busca de respostas. "Se uma questão o impressiona e o apaixona, ele dará tudo o que pode, mais facilmente, do que se não tiver estímulo algum, mesmo empregando-se os mais geniais processos pedagógicos" No entanto, despertar o interesse da criança, por si só, não é o bastante, pois, para o autor (1933, p.239), "é necessário que cada uma das fases sucessivas recorde ao mesmo tempo a que precede e desperte o interesse pela que se vai seguir".

Explicitado o escopo do conceito deweyano de experiência, pano de fundo da análise de dados, pretende-se agora olhar cada fonte procurando os fatores que colaboram para a elucidação das questões com as quais se compromete essa pesquisa. Nesse sentido, apresentam-se os seguintes elementos:

Projeto Político Pedagógico (PPP) e Plano de Formação (PF). Por meio da análise do PPP, no interior do qual se encontra o PF da unidade, será discutida a organização curricular que ela pretende, bem como a organização do processo de formação PEA adotado pelo CEI.

Planos de trabalho e registro das professoras: essa fonte fornecerá elementos para se discutir o modo como as quatro professoras documentam as ações e produções das crianças, assim como permitirá investigar em que medida é possível construir um planejamento articulado. Também será possível examinar como se constituem as práticas em ambos os períodos.

Diário de campo da pesquisadora: essa fonte fornecerá subsídios para se compreender o quanto o planejamento se revela nas ações, o que possibilitará um maior 
entendimento sobre aquilo que as crianças de fato vivenciam e, por fim, permitirá indagar se essas experiências se constituem enquanto experiências educativas expressivas, sob a ótica dos conceitos deweyanos de interação e continuidade.

Entrevistas com as quatro professoras, coordenadora pedagógica e diretora. Por meio dessa fonte de dados pretende-se mostrar como esses atores percebem o processo de formação no contexto da unidade e em que medida as professoras conseguem trocar experiências e unificar o planejamento durante esse processo. Pretende-se também identificar como esses sujeitos avaliam o próprio trabalho, em outros termos, como identificam a qualidade das experiências vivenciadas pelas crianças nos dois períodos.

Sob essa ótica, pretende-se discutir no capítulo subsequente as práticas partilhadas por quatro professoras de um mesmo agrupamento com vistas a perceber como são planejadas as ações e como acontecem as experiências cotidianas com as turmas. 


\title{
5. CENTRO DE EDUCAÇÃO INFANTIL EM ESTUDO: CURRÍCULO VIVIDO NOS PLANOS DE QUATRO PROFESSORAS
}

\begin{abstract}
A curiosidade eleva-se além do plano material e social; converte-se em intelectual, à proporção que se metamorfoseia em interesse pelos problemas originados da observação das coisas e pela acumulação dos fatos (DEWEY, 1933, p.47).
\end{abstract}

O objetivo deste capítulo é analisar as ponderações sobre o currículo vivido feitas pelas quatro professoras que dividem o mesmo agrupamento. Dessa forma, pretende-se compreender como elas organizam sua prática em torno de um

planejamento comum para a mesma turma. À luz do conceito de experiência posto por John Dewey (1980), serão analisados os dados obtidos mediante o exame dos documentos produzidos pela unidade, dos registros de observação feitos no CEI e dos depoimentos recolhidos nas entrevistas realizadas com as quatro professoras, a coordenadora pedagógica e a diretora. Como exposto no capítulo anterior, para Dewey (1980), uma experiência realmente expressiva, marcante, deve obedecer a dois critérios, a saber: (1) a continuidade - característica da experiência que, por suscitar outras experiências, não se isola em momentos pontuais, sendo posteriormente esquecida; (2) e a interação, traço próprio às experiências significativas, que estão imersas em um contexto particular, não acontecem no vazio (PINAZZA, 2007).

Com base nesses princípios, buscou-se estabelecer uma discussão a fim de entender em que medida as vivências da turma de crianças configuram-se como experiências educativas expressivas.

Inicialmente, apresenta-se os resultados alcançados a partir do exame de cada uma das fontes de dados, já indicadas no capítulo anterior. Em seguida, é introduzida uma discussão geral em que são relacionados todos os dados produzidos em forma de possíveis conclusões do estudo.

\subsection{Projeto Político Pedagógico e Plano de Formação das Professoras}


Nessa fonte de dados, o exame teve como foco a orientação curricular pretendida pela unidade, bem como a organização do processo de formação em PEA adotado pelo CEI.

Contendo 78 páginas, o Projeto Político Pedagógico (PPP) traz informações relevantes sobre o processo educativo idealizado pela unidade. Nesse documento, foi possível encontrar informações que vão desde a estrutura física da unidade, passando pelo anúncio das concepções adotadas até o delineamento de planos de ação, seja para o trabalho com as crianças, seja para a formação da equipe.

É possível observar a preocupação em construir um projeto próprio da unidade e a importância dada ao desafio de se pensar o currículo para a infância. Para tanto, pautase em documentos oficiais como: as Diretrizes Curriculares Nacionais para a Educação Infantil (BRASIL, 2009) e os Critérios para um atendimento em creches que respeite os direitos fundamentais das crianças (BRASIL, 2009). Considerando essas bases legais, a unidade se propõe a:

\begin{abstract}
Promover o desenvolvimento integral da criança de zero a cinco anos de idade, oferecendo condições e recursos para que a criança, sujeito histórico e de direito, possa vivenciar e interagir nas práticas cotidianas, com outras crianças, construir sua identidade pessoal e coletiva. Além disso, que a escola crie espaços de brincadeiras, experimentações fantasias, observações, experimentações e incentive o questionamento, construindo sentidos sobre a natureza, a sociedade e seja produtora de culturas. Devem ainda garantir a convivência entre crianças e entre adultos e crianças, a ampliação dos saberes e conhecimentos de diferentes naturezas. Promover a igualdade de oportunidades educacionais entre crianças de diferentes classes sociais no que se refere ao acesso aos bens culturais e às possibilidades de vivência da infância. Construindo novas formas de sociabilidade e de subjetividade comprometidas com a ludicidade, a democracia, a sustentabilidade do planeta e com o rompimento de relações de dominação etária, socioeconômica, étnico-racial, de gênero, regional, linguística e religiosa (Projeto Político Pedagógico do CEI, 2013, p.16).
\end{abstract}

Alinhada a essa concepção pedagógica, está a proposta curricular da Pedagogiaem-Participação, que representa uma fonte de inspiração do CEI pesquisado, e também é uma referência importante para o grupo de pesquisa Contextos Integrados de Educação Infantil, da Faculdade de Educação da USP, do qual a unidade é parceira. Oliveira-Formosinho (2007), importante autora da corrente da Pedagogia-emParticipação, enfatiza que uma Pedagogia da Infância deve ter como premissa a crença de que todas as pessoas têm agência. Nesse sentido, a criança é vista como pessoa, ativa, criativa e potente e, portanto, localiza-se juntamente com professores(as) no 
centro da construção dos saberes. No mesmo sentido, Barbosa e Richter (2011) destacam a importância de um olhar específico para a infância, seus saberes e fazeres.

Pode ser observado no cotidiano da unidade que, de acordo com o PPP, o trabalho está pautado numa concepção democrática. E, dentro dessa concepção, compreende-se a centralidade que as crianças ocupam nas experiências educativas promovidas, bem como o destaque aí conferido à interação, como fator imprescindível na busca da ampliação das vivências infantis.

Como premissa, o PPP da unidade pretendeu durante o ano de 2013:

\begin{abstract}
Pensar o currículo, contemplando a reorganização dos espaços visando aperfeiçoar e contemplar as necessidades das crianças quanto ao brincar, segurança, desafios e escolhas, ampliando as vivências e enriquecendo suas experiências, contemplando também o educador no seu fazer pedagógico, na organização dos tempos e espaços e nas intervenções, refletindo na melhoria da qualidade da educação infantil (Projeto Político Pedagógico do CEI, 2013, p.11).
\end{abstract}

Ao pensar o currículo, o CEI se propõe a enriquecer e ampliar as experiências infantis. Pinazza (2007) mostra que o conceito de experiência de Dewey se diferencia da simples sensação isolada atributos dos objetos, uma vez que não os percebemos passivamente. Assim posto, o currículo e, portanto, a prática pedagógica deve contemplar tempos e espaços adequados para que as experiências das crianças estejam bem contextualizadas e possam ser de fato ampliadas, engendrando assim outras experiências, crescentemente.

O currículo expresso no PPP da unidade anuncia uma concepção de criança integral, única, ativa, capaz, construtora de conhecimento e produtora de cultura. Sinaliza também que a proposta educativa do CEI contempla, de acordo com o que preconizam os documentos oficiais, os direitos fundamentais das crianças, a saber:

$>\mathrm{O}$ direito à brincadeira;

$>$ O direito à atenção individual;

$>$ O direito a um ambiente aconchegante, seguro e estimulante;

$>$ O direito ao contato com a natureza;

$>\mathrm{O}$ direito à saúde;

$>$ O direito à alimentação sadia;

$>\mathrm{O}$ direito a desenvolver a curiosidade, imaginação e capacidade de expressão; 
$>$ O direito aos movimentos em espaços amplos;

$>\mathrm{O}$ direito à proteção, afeto e amizade;

$>$ O direito a expressar seus sentimentos;

$>\mathrm{O}$ direito a uma especial atenção durante seu período de adaptação à creche;

$>$ O direito a desenvolver sua identidade cultural, racial e religiosa (Projeto Político Pedagógico do CEI, 2013, p.17).

No que tange à estrutura organizacional para o trabalho pedagógico apresentada no PPP, adotam-se as chamadas 'áreas de experiências', tais como definidas nas Orientações Curriculares Municipais (SÃO PAULO, 2010). Sendo assim, a organização do trabalho pedagógico deve estar pautado em experiências nas seguintes áreas: experiências voltadas ao cuidado de si, do outro e do ambiente; experiências do brincar e imaginar; experiências de exploração da linguagem matemática; experiência de apropriação da natureza e cultura; experiências com a expressividade das linguagens artísticas.

Em seus objetivos, o PPP da unidade preconiza, entre outras questões:

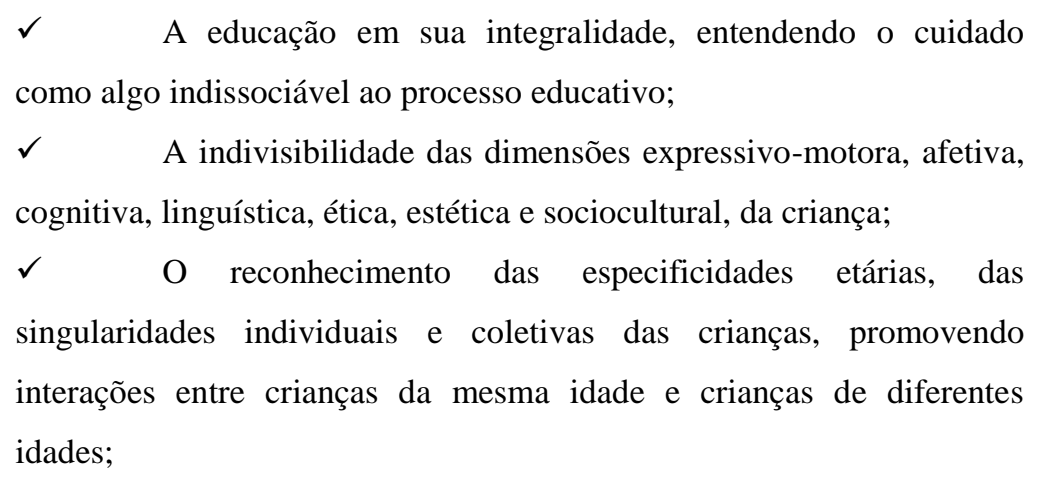
como algo indissociável ao processo educativo;

$\checkmark \quad$ A indivisibilidade das dimensões expressivo-motora, afetiva, cognitiva, linguística, ética, estética e sociocultural, da criança;

$\checkmark \quad$ O reconhecimento das especificidades etárias, das singularidades individuais e coletivas das crianças, promovendo interações entre crianças da mesma idade e crianças de diferentes idades;

$\checkmark \quad$ Os deslocamentos e os movimentos amplos das crianças nos espaços internos e externos às salas de referência das turmas e à Instituição (Projeto Político Pedagógico do CEI, 2013, p.18).

Do exposto, conclui-se que a orientação curricular pretendida pela unidade demonstra está alinhada com concepções estabelecidas pelos documentos oficiais, como as Diretrizes Curriculares Nacionais para a Educação Infantil (BRASIL, 2009), os Critérios para um atendimento em creches que respeite os direitos fundamentais das crianças (BRASIL, 2009) e as Orientações Curriculares Municipais (SÃO PAULO, 2010). Além disso, pauta-se em concepções progressistas que consideram a criança em 
sua integralidade, como ser único, completo e que necessita de vivências e experiências ricas e expressivas, o que pressupõe continuidade e interação.

O PPP da unidade informa que a organização do processo de formação em PEA ocorre em dois momentos específicos: das $7 \mathrm{~h} 00$ às $8 \mathrm{~h} 00$, somente com as professoras do período da manhã, sob a coordenação da diretora; e das 18 h00 às 19 h00, somente com as professoras do período da tarde, sob a coordenação da coordenadora pedagógica. Não é prevista, portanto, nenhuma formação que reúna toda a equipe, ou seja, não é assegurado definitivamente um tempo institucional em que as professoras possam trocar experiências de prática e mesmo planejar juntas as ações direcionadas ao agrupamento de crianças. Conforme aponta o texto, ocorrem momentos pontuais de formação, em diferentes períodos, o que permite supor, apesar da coordenação realizada pela gestão, a dificuldade que as professoras encontram para estabelecerem entre si e, por conseguinte, construir práticas partilhadas e articuladas.

Constata-se, ademais, a insuficiência de tempo para a formação em serviço centrada na unidade educacional. Há somente três horas semanais dedicadas à formação garantidas pelo PEA e duas horas dedicadas ao planejamento. Essas horas de formação se concentravam no período de trabalho de cada professora e, no CEI em questão, coincidiam com o período da pesquisa de campo. A divisão dos períodos de formação entre a diretora e a coordenadora deixava a interlocução entre eles ainda mais prejudicada, pois as professoras do período da manhã podiam conversar com a coordenadora pedagógica apenas informalmente, nas visitas que ela fazia eventualmente às salas.

A própria legislação que regulamenta o PEA define como objetivo principal desse momento de formação providenciar momentos de estudos para, em última instância,

[...] assegurar a todas as crianças a vivência de experiências significativas e variadas, utilizando diferentes linguagens, entendendo as práticas sociais da linguagem oral e escrita como organizadoras dessas experiências (SÃO PAULO, 2008).

Contudo, não se pensou em uma estrutura de organização formativa que desse às professoras uma possibilidade de pensar conjuntamente as experiências propiciadas às crianças, uma vez que não há, no terreno da instituição, momentos para planejá-las de forma concertada. Dessa maneira, não há espaço, nem mesmo durante a formação, 
para que as professoras, articulando-se, possam articular também suas práticas. Zeichner (1993) coloca como alternativa a realização da formação em coletivos por meio da transformação das escolas em comunidades de aprendizagem, o permitiria que os docentes, dialogando e expondo suas práticas e saberes espontaneamente, dessem suporte para a formação uns dos outros. Esse exigiria que os professores caminhassem coletivamente para a qualificação das ações pedagógicas, tal como propõe a própria legislação do PEA.

É possível supor que professoras, e adultos de modo geral, que não vivenciam experiências de aprendizagem contínuas e intimamente relacionadas com suas práticas cotidianas, isto é, experiências expressivas, não compreenderão os mecanismos que as tornam possíveis com as crianças. É o que parece ocorrer no caso das professoras em PEA, como consequência da própria organização do tempo-espaço de formação proposta pelo sistema da rede municipal que, desse modo, comprometendo o planejamento das professoras, dificulta a experiência de aprendizagem das crianças. .

\subsection{Entrevistas com as quatro professoras, coordenadora pedagógica e diretora.}

Essa fonte não apenas forneceu elementos para estabelecer uma discussão sobre o modo como as professoras percebem o próprio trabalho como também permitiu indagar se conseguem avaliar a qualidade de experiência das crianças. Ademais, o trabalho com essa fonte possibilitou conhecer a forma como esses sujeitos percebem a formação no âmbito da unidade e investigar em que medida as professoras conseguem trocar experiências e unificar o planejamento nesses tempos de formação.

Embora o exposto no PPP da unidade mostre preferência pelas práticas que favorecem o desenvolvimento das experiências das crianças num continuum, no qual elas podem se ampliar cada vez mais, com vistas a uma formação integral, as entrevistas dão conta de uma maneira de organização curricular que, tendendo à fragmentação de experiências e saberes, subordina os momentos educativos a uma lógica de componentes curriculares, à semelhança das "disciplinas escolares".

Assim, no período da tarde, enfatiza-se um bloco de acontecimentos experienciais e, no período da manhã, outro. Ou seja, o currículo oficial da unidade está subdividido em diferentes "linguagens". Cada período trabalha determinadas linguagens, o que 
impossibilita uma fluidez nas ações e uma verdadeira articulação no planejamento do trabalho diário para a turma. Como dizem as professoras O., V. e I.

Eles (planejamento) não se conversam, porque a gente teve a brilhante ideia de pedir que fosse dividido em linguagens, porque a gente pensa que a criança fica o dia inteiro na instituição e que as vezes, por exemplo, a gente só propõe roda de história porque a professora gosta muito de contar história, sem fazer outro tipo de exploração, desenvolver outra atividade, por isso a gente dividiu o por linguagens, assim, se de manhã a criança já experienciou vivências com artes plásticas, a tarde ela vai experienciar vivências com a linguagem matemática (depoimento da professora $\mathrm{O}$.)

[...] Nós dividimos as linguagens, por exemplo, de manha, focamos a linguagem oral, a tarde elas focam a matemática, nós focamos artes, elas focam mais no movimento, porque a criança fica aqui o dia todo, assim não fica cansativo para ela. Por exemplo, a "biblioteca itinerante" na sexta-feira a tarde elas fazem o empréstimo, mais como nós ficamos com a linguagem oral, nós e que fazemos a devolutiva com as crianças na segunda-feira (depoimento da professora V.)

A gente divide as linguagens, é uma coisa meio que separado, ao mesmo tempo é junto, nós sabemos tudo que elas estão fazendo, elas sabem o que a gente está fazendo, até mesmo um dia que tem vídeo pra elas, não tem vídeo pra nos, um filme que elas já passaram nós não vamos repetir, porque a gente sabe que foi feito o trabalho com aquele filme (depoimento da professora I)

Observa-se que, nesse contexto, as linguagens infantis são entendidas como “disciplinas". Barbosa e Richter (2011) alertam que a pedagogia, muitas vezes, esquece que as linguagens emergem de dentro do corpo, que nascem no instante em que alguém toma a iniciativa e se exterioriza para fora do corpo. Nesse sentido, aprender torna-se algo infinito, uma vez que nada é previsto ou pré-determinado.

\section{Como asseveram Barbosa e Richter (2011, p. 18),}

Aprender, nessa perspectiva, não implica apenas explorar mas reconfigurar a realidade conseguir refazer os próprios passos poder recontar algo que queremos compartilhar desvendar os segredos das linguagens pela intensidade narrativa de um corpo encenando o mundo. $\mathrm{O}$ que as crianças mostram à educação em seu poder de realizar a passagem da desordem interna (espanto, maravilhamento, admiração, surpresa, perplexidade) à execução de algo (traços, manchas, figuras, objetos, palavras) é que não há aprendizagem da autonomia sem o poder de regozijo. O regozijo de animar as coisas e emprestar-lhes uma existência poética em sua conquista linguageira de brechas entre vida real e vida fabulada.

A maneira como pensam e vivem o planejamento revela o próprio processo de formação vivido pelas professoras. Até o ano de 2012, havia na prefeitura municipal de São Paulo um projeto de formação chamado "a Rede em Rede" ${ }^{18}$. Tal projeto organizava a formação em torno de linguagens específicas, de modo que as professoras

\footnotetext{
${ }^{18}$ Questões específicas do referido programa foram tratadas no capítulo I desta Dissertação.
} 
de educação infantil da rede municipal aprendiam a trabalhar cada linguagem separadamente, havendo cursos que intentavam dar às professoras instrumentos para o trabalho com linguagem matemática, artes plásticas, música, teatro entre outras. Ou seja, a lógica da fragmentação estava presente desde a formação proposta pela SME.

Como escreve Barbosa (2010), é preciso abandonar a concepção curricular prescritiva e fragmentada, adotando uma concepção interativa, construída em colaboração com meninos e meninas, pautada nas narrativas estabelecidas no cotidiano da instituição a partir do vínculo das linguagens com a vida.

A ausência de interlocução entre o planejamento das duplas, uma das expressões da fragmentação curricular, pode ser percebido também na fala da professora P., quando ela diz que:

Não temos um planejamento comum, eu vejo assim, a gente trabalha como o nosso e elas com o delas, mais ações conjuntas mesmo eu não consigo enxergar, porque eu acho que a gente não consegue trocar, conversar, não temos horários para isso, então não temos trocas, não conseguimos planejar juntas (depoimento da professora P.).

Por outro lado, a fala da professora V. indica que no planejamento também há espaço para o trabalho com projetos.

Esse ano, primeiro nós conhecemos as crianças e ai apareceu o peixinho que foi doação de um pai para nossa turma, partiu dai o "projeto animal" que estamos trabalhando, partindo do que as crianças trouxeram. Um dia nós estávamos com tudo organizado para uma atividade, então a professora de outra sala trouxe uma tartaruga marinha para nossa sala porque ela sabia que as crianças estavam pesquisando sobre o peixinho, nós paramos tudo para que as crianças pudessem conhecer a tartaruga. Então não é aquela coisa fechada sabe. A criança trouxe uma coisa bacana, a gente muda os planos (depoimento da professora V.)

Como escreve Pinazza (2014), hoje em dia, o trabalho com projetos está presente em muitas recomendações que defendem ações inovadoras na educação, sobretudo na educação da infância. Tais perspectivas vão ao encontro da essência da Pedagogia-em-Participação, de acordo com Oliveira-Formosinho ( 2011)

Os objetivos da educação na Pedagogia-em-Participação são os de apoiar o envolvimento da criança no continuum experiencial e a construção da aprendizagem através da experiência interativa e continua, dispondo a criança tanto do direito à participação como do direito ao apoio sensível, autonomizante e estimulante por parte do(a) educador(a) ( OLIVEIRAFORMOSINHO, 2011, p.103) 
De fato, esse apoio cuidadoso para que as crianças tenham experiências contínuas e interativas destaca-se sobremaneira no trabalho com projetos. Contudo, embora as duplas de professoras entendam que, por meio dos projetos, a criança pode vivenciar experiências de aprendizagens de maior qualidade, elas ainda encontram certa dificuldade de efetivar tais ações.

Ao planejar o trabalho, as duplas de professoras consideram uma série de motivações que envolvem, sobretudo, o bem estar, o prazer e a felicidade das meninas e meninos.

[...] eu penso através do que eles trazem. Como avançar na pesquisa com eles. Quando não trazem nenhuma demanda, ou quando só uma criança que traz uma questão. Como é que eu posso fazer que isso se encaminhe para uma pesquisa? Para um planejamento de uma atividade? (depoimento da professora O.).

Quando eu penso na minha prática eu penso em fazer atividades que eles gostam que eles sintam prazer em fazer, porque eu não vou mentir não, já trabalhei em um lugar que você dava a atividade para criança e se ela estava mexendo com uma meleca, não podia se sujar então ela tem que ficar bem atenta. Isso não tem a mínima graça e ai você vê que só está dando por dar a atividade, porque está lá no seu planejamento, que você vai trabalhar com a meleca (depoimento da professora P.).

[...] deu certo a gente está fazendo uma coisa hoje se foi bacana já acrescentamos outra, a gente vai enganchando. O que deu certo já vamos focando na próxima semana (depoimento da professora V.).

Oferecer o melhor de mim, o melhor do que eu posso, eu acho que a criança fica tanto tempo fora de casa, que ele se sinta bem que se sinta seguro com a gente no que está fazendo, que cresça mesmo (depoimento da professora I.).

Esses depoimentos revelam o comprometimento das professoras com o grupo de crianças e a intenção de lhes oferecer as melhores experiências possíveis. Contudo, esse desejo muitas vezes esbarra em fatores historicamente constituídos, como a desvalorização associada à educação das crianças pequenas e à formação de seus profissionais. Apesar desse background histórico, é preciso reconhecer que tem havido conquistas. Dentre elas, o espaço, ainda que limitado, para a formação continuada no contexto da própria unidade por meio do PEA.

No CEI em que se deu a pesquisa, bem como nos demais CEIs do município de São Paulo, há apenas 3 horas destinadas à formação e ao estudo contemplados pelo PEA. Particularmente no CEI estudado, o PEA acontece três vezes por semana tanto no período da manhã quanto no da tarde. Como diz a diretora,

Ocorre três vezes por semana, uma hora de horário coletivo, que elas fazem tanto de manhã quanto de tarde, período da manha das 7:00 as 8:00 horas e período da tarde 
das 18:00 as 19:00 horas, é obrigatório todas elas participaram, pela jornada do CEI todo mundo participa (depoimento da diretora).

Essa organização prejudicou bastante o processo de formação no CEI, o que se revela na seguinte fala da coordenadora pedagógica:

O ideal seria eu ficar os dois períodos no PEA, como era o ano passado, eu entrei aqui em 2011, e tinha alguns dias de manhã com as professoras da manhã e alguns dias à tarde. Então dava para acompanhar e dava também para pontuar as dificuldades do pessoal da manha, eu sei que elas ficam sem um auxílio fica difícil e não dá para acompanhar a distância (depoimento da coordenadora pedagógica).

Já para a diretora, o problema estava no escasso tempo destinado ao PEA e no grande número de professoras, o que dificultava a discussão.

[...] uma hora pro PEA era pouco, e o que eu acho que dificultava é que era um número grande de professores pra fazer discussão, acho que às vezes o PEA se tornava um pouco improdutivo pelo número muito grande de professores. Eu fazia PEA com quinze professores, é muita gente, ou virava um debate muito caloroso ou tinha aquelas pessoas que não conseguiam participar por que a voz dela não conseguia chegar (depoimento da diretora).

As professoras, além de reconhecerem a importância desse momento destinado à formação, também assinalam que a fragmentação do processo formativo dificulta a interlocução entre as duplas e a organização de um planejamento mais harmonioso. As professoras consideram o PEA uma importante conquista para os Centros de Educação Infantil, contudo fazem ressalvas à forma como ele se organiza na unidade:

Eu acho que o PEA é muito engessado [...] mas o fato de ele acontecer acho que é uma oportunidade de estudo [...] acho que tem coisas que são de estudo e não estão na bibliografia do PEA, por exemplo ,uma coisa que aconteceu com a criança uma coisa que serve como experiência pra todo mundo, nunca pode abrir em horário de PEA, porque o horário de PEA não é horário disso, ou quando a gente precisa fazer relatório das crianças [...] considero que o horário de PEA deveria ser mais aberto (depoimento da professora $\mathrm{O}$ ).

Nessa mesma direção, está o depoimento da professora $\mathrm{V}$., que pondera:

Na verdade o encontro de formação foi um ganho para nós profissionalmente tivemos um momento de sentar, estudar, de ler, foi uma luta grande para nossa categoria, de repente hoje nos incluímos isso na nossa jornada [...] O que eu vejo como sugestão é do coordenador acompanhar esse PEA porque é ele que acompanha a parte pedagógica, então o que eu dou de sugestão é isso que de repente a gente consiga voltar essa questão do coordenador pedagógico acompanhar, porque eu acho que ele que faz essa mediação esse elo com o trabalho dos professores.

A presença da coordenadora pedagógica em ambos os períodos, a fim de acompanhar o PEA, é um fator decisivo para a eficácia da comunicação entre as duplas. Contudo, questões organizativas do CEI inviabilizaram isso, uma vez que, pelo menos 
durante o ano de 2013, a diretora da unidade não teve condições de flexibilizar os seus horários, o que impossibilitou a presença da coordenadora pedagógica durante o PEA da manhã.

À época da pesquisa no CEI, sem o suporte de uma profissional na assistência à direção, a diretora e a coordenadora pedagógica precisaram constituir um sistema de abertura e fechamento da unidade que implicou revezamentos e rearranjos de horários que afetaram diretamente a supervisão dos trabalhos em momentos de formação e planejamento.

Pinazza afirma que a possibilidade de reunir, em um mesmo momento de formação, as várias professoras que atuam no mesmo agrupamento constitui um valioso diferencial para o processo formativo, mas, além disso, mostra, a partir de uma experiência desenvolvida em outro CEI de São Paulo, que o tempo de duração das reuniões é um fator de fundamental importância.
O diferencial do processo formativo realizado dentro do CEI A.S. foi conferido, essencialmente, por duas medidas adotadas pela equipe: a possibilidade de reunir em um mesmo momento de formação as professoras que atuavam no mesmo agrupamento de crianças, nos períodos da manhã e da tarde; e o fato de os encontros terem uma duração de duas horas (Pinazza, 2014, p. 105).

No período em que se deu a pesquisa de campo, havia na unidade um esforço em estabelecer mais um espaço de formação, em parceria com uma pesquisadora da Faculdade de Educação da USP. Quinzenalmente, com a participação das professoras que desejassem, aconteciam encontros de formação. A equipe gestora da unidade estava empenhada em organizar os tempos e espaços de forma a criar condições para que as professoras se envolvessem com esse canal de discussão. Essa iniciativa, contudo, não emanava da Diretoria Regional de Educação, que somente autorizava o acontecimento dos encontros.

Do exposto, nota-se que o espaço de formação no contexto do CEI contemplado pelo PEA não bastava para garantir trocas de experiências entre as duplas de professoras, muito menos para que planejassem juntas. Nem mesmo as gestoras conseguiam estabelecer uma comunicação efetiva entre elas, o que é confirmado, nos depoimentos das profissionais. 
Com a coordenadora, a gente tinha contato direto, ano passado especificamente nós tivemos problemas na questão da comunicação por conta dos nossos horários, eu ficava apenas de manhã e ela apenas no período da tarde (depoimento da diretora).

As comunicações com os professores eu tenho um livro registro que eu faço os comunicados por escrito, achei melhor porque era muito confuso discutir só no PEA depois não registrar isso, então eu costumo discutir no PEA e fechar no coletivo e depois eu coloco por escrito e elas tomam ciência. Com a diretora nós conversamos na hora e medida que vai sendo possível, nos não temos horários certos (depoimento da coordenadora).

\subsection{Planos de Trabalho e Registro das Professoras}

Buscou-se, com base nessas duas fontes de dados, estabelecer uma discussão que contribuísse para a compreensão da forma como as duplas de professoras documentam as ações e as produções das crianças e como se constituem as práticas educativas em cada período a partir do plano das professoras. Por fim, o objetivo também foi identificar possibilidades de construção de um planejamento articulado. Partiu-se do pressuposto de que o planejamento comum entre as duplas possibilita maior qualidade às experiências vivenciadas pelas crianças, sempre que orientadas pelos princípios da continuidade e da interação. Isso implica dizer que uma experiência interessante iniciada no período da manhã deveria suscitar outras experiências correlatas, em continuidade, no período da tarde. Assim, as crianças não vivenciariam momentos tão descolados da rotina. Como posto nas DCNEIs (2009),

As práticas pedagógicas devem ocorrer de modo a não fragmentar a criança nas suas possibilidades de viver experiências, na sua compreensão do mundo feita pela totalidade de seus sentidos, no conhecimento que constrói na relação intrínseca entre razão e emoção, expressão corporal e verbal, experimentação prática e elaboração conceitual (BRASIL, 2009, p. 9).

Como instrumentos para documentar as práticas, as professoras se valem especificamente dos seguintes tipos de registros: diário de classe, caderno de ocorrências e/ou comunicação e semanário. No diário de classe são registradas as atividades realizadas durante o dia em cada período. O caderno de ocorrência é um instrumento de comunicação entre as duplas de professoras, em que são registradas informações e acontecimentos ocorridos durante o período, que uma dupla julgue necessário informar à outra.

Dessa forma, são registrados, por exemplo: dados sobre alimentação das crianças, entradas e saídas de crianças fora do tempo regular, ocorrências de acidentes ou de 
distúrbios de saúde, mudanças de comportamento relacionadas à alimentação ou à higiene etc. No semanário, as professoras registram o planejamento semanal para a turma. Também são descritos e relatados algumas momentos vividos com as crianças, principalmente aqueles considerados mais relevantes pelas professoras.

Apresentam-se abaixo os quadros com os planos de trabalhos das duplas de professoras. Eles ficavam expostos no PPP da unidade, nomeados como quadro curricular, como se vê nas tabelas 7 e 8 .

Tabela 7 - Quadro Curricular: Mini-grupo I A/B - Professoras: P. e V. - manhã

\begin{tabular}{|c|c|c|c|c|c|}
\hline Horário & $2^{a}$ feira & $3^{a}$ feira & $4^{a}$ feira & $5^{a}$ feira & $6^{a}$ feira \\
\hline $\begin{array}{c}\text { 08h15 - } \\
08 \mathrm{~h} 30\end{array}$ & $\begin{array}{c}\text { Acolhimento } \\
\text { Higiene }\end{array}$ & $\begin{array}{c}\text { Acolhimento } \\
\text { Higiene }\end{array}$ & $\begin{array}{c}\text { Acolhimento } \\
\text { Higiene }\end{array}$ & $\begin{array}{c}\text { Acolhimento } \\
\text { Higiene }\end{array}$ & $\begin{array}{c}\text { Acolhiment } \\
\text { o } \\
\text { Higiene }\end{array}$ \\
\hline $\begin{array}{c}08 \mathrm{~h} 50- \\
09 \mathrm{~h} 00\end{array}$ & $\begin{array}{c}\text { Roda inicial, } \\
\text { campo } \\
\text { dirigido }\end{array}$ & $\begin{array}{c}\text { Roda inicial, } \\
\text { campo } \\
\text { dirigido }\end{array}$ & $\begin{array}{c}\text { Roda inicial, } \\
\text { campo } \\
\text { dirigido }\end{array}$ & $\begin{array}{c}\text { Roda inicial, } \\
\text { campo } \\
\text { dirigido }\end{array}$ & $\begin{array}{c}\text { Roda } \\
\text { inicial, } \\
\text { campo } \\
\text { dirigido }\end{array}$ \\
\hline $\begin{array}{c}\text { 09h00 - } \\
09 \mathrm{~h} 45\end{array}$ & Parque & Parque & Parque & Parque & Parque \\
\hline $09 \mathrm{~h} 45$ & Suco & Suco & Suco & Suco & Suco \\
\hline $\begin{array}{c}10 \mathrm{~h} 00 \text { - } \\
10 \mathrm{~h} 45\end{array}$ & $\begin{array}{l}\text { Atividade } \\
\text { Projeto } \\
\text { Identidade }\end{array}$ & $\begin{array}{l}\text { Atividade } \\
\text { Projeto } \\
\text { Animais }\end{array}$ & $\begin{array}{l}\text { Atividade } \\
\text { Salas } \\
\text { Ambientes }\end{array}$ & $\begin{array}{l}\text { Atividade } \\
\text { Vídeo }\end{array}$ & $\begin{array}{l}\text { Atividade } \\
\text { Jogos e } \\
\text { Artes }\end{array}$ \\
\hline $\begin{array}{c}10 \mathrm{~h} 45- \\
11 \mathrm{~h} 00\end{array}$ & Higiene & Higiene & Higiene & Higiene & Higiene \\
\hline $\begin{array}{c}11 \mathrm{~h} 00- \\
11 \mathrm{~h} 30\end{array}$ & Almoço & Almoço & Almoço & Almoço & Almoço \\
\hline $\begin{array}{c}11 \mathrm{~h} 30- \\
12 \mathrm{~h} 00\end{array}$ & $\begin{array}{l}\text { Escovação } \\
\text { Sono }\end{array}$ & $\begin{array}{l}\text { Escovação } \\
\text { Sono }\end{array}$ & $\begin{array}{l}\text { Escovação } \\
\text { Sono }\end{array}$ & $\begin{array}{l}\text { Escovação } \\
\text { Sono }\end{array}$ & $\begin{array}{c}\text { Escovação } \\
\text { Sono }\end{array}$ \\
\hline
\end{tabular}




\begin{tabular}{|l|l|l|l|l|l|}
\hline & & & & & \\
\hline
\end{tabular}

Tabela 8 - Quadro Curricular: Mini-grupo I A/B - Professoras: O. e I. - tarde

\begin{tabular}{|c|c|c|c|c|c|}
\hline Horário & $2^{a}$ feira & $3^{a}$ feira & $4^{\mathrm{a}}$ feira & $5^{a}$ feira & $6^{\text {a }}$ feira \\
\hline $\begin{array}{c}12 \mathrm{~h} 00- \\
14 \mathrm{~h} 00\end{array}$ & Sono & Sono & Sono & Sono & Sono \\
\hline $14 \mathrm{~h} 00$ & $\begin{array}{c}\text { Higiene e } \\
\text { preparo para } \\
\text { o lanche }\end{array}$ & $\begin{array}{c}\text { Higiene e } \\
\text { preparo para o } \\
\text { lanche }\end{array}$ & $\begin{array}{c}\text { Higiene e } \\
\text { preparo para o } \\
\text { lanche }\end{array}$ & $\begin{array}{c}\text { Higiene e } \\
\text { preparo para o } \\
\text { lanche }\end{array}$ & $\begin{array}{c}\text { Higien } \\
\mathrm{e} \text { e } \\
\text { preparo } \\
\text { para o } \\
\text { lanche }\end{array}$ \\
\hline $14 \mathrm{~h} 30$ & Lanche & Lanche & Lanche & lanche & Lanche \\
\hline $14 \mathrm{~h} 50$ & $\begin{array}{c}\text { Parque livre } \\
\text { e dirigido }\end{array}$ & $\begin{array}{l}\text { Parque livre e } \\
\text { dirigido }\end{array}$ & $\begin{array}{l}\text { Parque livre e } \\
\text { dirigido }\end{array}$ & $\begin{array}{c}\text { Parque livre e } \\
\text { dirigido }\end{array}$ & $\begin{array}{c}\text { Parque } \\
\text { livre e } \\
\text { dirigid } \\
\quad 0\end{array}$ \\
\hline $15 \mathrm{~h} 20$ & $\begin{array}{c}\text { Hidratação - } \\
\text { água }\end{array}$ & $\begin{array}{l}\text { Hidratação - } \\
\text { água }\end{array}$ & $\begin{array}{c}\text { Hidratação - } \\
\text { água }\end{array}$ & $\begin{array}{c}\text { Hidratação - } \\
\text { água }\end{array}$ & $\begin{array}{c}\text { Hidrata } \\
\text { ção - } \\
\text { água }\end{array}$ \\
\hline $15 \mathrm{~h} 20$ & $\begin{array}{l}\text { Atividades } \\
\text { vídeo }\end{array}$ & $\begin{array}{l}\text { Atividades } \\
\text { Circuito }\end{array}$ & $\begin{array}{l}\text { Atividades } \\
\text { Melecas }\end{array}$ & $\begin{array}{c}\text { Atividades } \\
\text { Pesquisa } \\
\text { Sonora }\end{array}$ & $\begin{array}{l}\text { Ativida } \\
\text { des } \\
\text { Brinca } \\
\text { deiras }\end{array}$ \\
\hline $16 \mathrm{~h} 00$ & Jantar & Jantar & Jantar & Jantar & Jantar \\
\hline $16 \mathrm{~h} 30$ & $\begin{array}{l}\text { Higiene } \\
\text { Escovação }\end{array}$ & $\begin{array}{l}\text { Higiene } \\
\text { Escovação }\end{array}$ & $\begin{array}{l}\text { Higiene } \\
\text { Escovação }\end{array}$ & $\begin{array}{l}\text { Higiene } \\
\text { Escovação }\end{array}$ & $\begin{array}{l}\text { Higien } \\
\text { e } \\
\text { Escova } \\
\text { ção }\end{array}$ \\
\hline $17 \mathrm{~h} 00$ & $\begin{array}{c}\text { Brincadeira } \\
\text { Livre }\end{array}$ & $\begin{array}{l}\text { Brincadeira } \\
\text { Livre }\end{array}$ & $\begin{array}{c}\text { Brincadeira } \\
\text { Livre }\end{array}$ & $\begin{array}{l}\text { Brincadeira } \\
\text { Livre }\end{array}$ & $\begin{array}{c}\text { Brinca } \\
\text { deira } \\
\text { Livre }\end{array}$ \\
\hline
\end{tabular}




\begin{tabular}{|c|c|c|c|c|c|}
\hline $17 \mathrm{~h} 40$ & $\begin{array}{c}\text { Saída- } \\
\text { transporte }\end{array}$ & $\begin{array}{c}\text { Saída- } \\
\text { transporte }\end{array}$ & $\begin{array}{c}\text { Saída- } \\
\text { transporte }\end{array}$ & $\begin{array}{c}\text { Saída- } \\
\text { transporte }\end{array}$ & $\begin{array}{c}\text { Saída- } \\
\text { transpo } \\
\text { rte }\end{array}$ \\
\hline $17 \mathrm{~h} 45$ & $\begin{array}{c}\text { Saída- } \\
\text { transporte }\end{array}$ & $\begin{array}{c}\text { Saída- } \\
\text { transporte }\end{array}$ & $\begin{array}{c}\text { Saída- } \\
\text { transporte }\end{array}$ & $\begin{array}{c}\text { Saída- } \\
\text { transporte }\end{array}$ & $\begin{array}{c}\text { Saída- } \\
\text { transpo } \\
\text { rte }\end{array}$ \\
\hline
\end{tabular}

Conforme o exposto nos "quadros curriculares" das duplas de professoras, durante o dia as crianças vivenciam momentos de higiene, brincadeira livre, alimentação e as chamadas “atividades". Não há, contudo, relação e continuidade entre as experiências desenvolvidas nos dois períodos. Dessa forma, , por exemplo, enquanto segunda-feira de manhã trabalha-se o "Projeto animais", à tarde, as crianças assistem a um vídeo totalmente desligado da questão tratada durante a manhã.

O currículo configura-se como um leque de experiências desconexas. O modelo de organização por linguagens que se concretiza em cada turno parece ser o mesmo que se encontra nas instituições escolares, o que revela a clara inserção de tradições escolares nos Centros de Educação Infantil. Como sustenta Barbosa (2010),

As instituições que atendem crianças com menos de três anos, recentemente se caracterizaram como escolares. Mas, pela demanda legal de sua inserção no sistema educacional como parte da Educação Básica, ou pela novidade de pensar a educação com bebês, as incorporações de tradições da escolarização no atendimento às crianças pequenas, parece ser o único ponto de partida para sustentar propostas pedagógicas na creche (BARBOSA, 2010, p.89).

Os Centros de Educação Infantil, uma vez que atendem crianças tão pequenas, devem ser pensados como instituições que possuem demandas singulares que não podem ser consideradas pela ótica da escolarização ou conduzidas por modelos transpostos da realidade escolar. Para tanto, é necessário, entre outras coisas, que haja tempos e espaços para a comunicação, planejamento, formação e reflexão entre os pares no interior das unidades, de maneira que a discussão, construção e reconstrução cotidianamente do currículo vivido sejam possíveis. Na contramão dessa ideia, o que se observa na prática é o canal de comunicação e planejamento disponível para as duplas se restringe ao caderno de ocorrência, semanário ou diário. Tais registros não dão conta da amplitude do processo, o que dificulta imensamente qualquer iniciativa em partilhar as ações e constituir algo conjuntamente. 
O que se observa no CEI focalizado neste estudo pode ser muito bem uma realidade enfrentada por outros CEIs do município. Trata-se de um grande obstáculo à qualidade das experiências de aprendizagens, pelo menos do ponto de vista da Pedagogia-em-Participação, na qual as interações representam uma dimensão essencial do currículo da educação infantil.

Como escreve Oliveira-Formosinho (2011, p. 104):

Entendemos a Pedagogia-em-Participação como a criação de espaços e tempos pedagógicos onde a ética das relações e interações permite desenvolver atividades e projetos que, porque valorizam a experiência, os saberes e as culturas das crianças em diálogo como os saberes e as culturas dos adultos, permitem as crianças viver, conhecer, significar, criar.

A ausência de momentos de interação entre as professoras no CEI é um dos fatores que compromete a coesão do trabalho que, por sua vez, favoreceria as crianças com experiências plenas de aprendizagem. Embora entendam que as crianças são potentes, falantes e precisam ser ouvidas, as professoras não conseguem articular seu trabalho por ausência de espaços e tempos para compartilhar suas próprias realizações, o que exerce um impacto direto sobre as vivências das crianças.

Essa condição experimentada no CEI não corresponde ao que preconiza a Orientação Normativa ${ }^{\circ} 01$ de 2013.

[...] o papel do educador (a) da infância é o de criar condições, organizar tempos e espaços, selecionar e organizar materiais de forma criativa, observar as crianças, avaliar processos construindo registros que historicizem o tempo vivido, apoiar as suas descobertas e projetos a fim de possibilitar a ampliação das experiências das crianças, sem que o foco esteja centrado nele e sim na ação e invenção dos meninos e das meninas (SÃO PAULO, 2013, p.15).

Tampouco se alinha com o que a proposta da Pedagogia-em-Participação prevê a respeito do processo de formação profissional.

A interatividade entre saberes, práticas e crenças construídas pelos atores na construção do seu itinerário de aprendizagem, mas em interação com os seus contextos de vida e com os contextos de ação pedagógico. Assim a interdependência entre os atores e os ambientes fazem da pedagogia da participação um espaço complexo onde lidar com a ambiguidade, a emergência, o imprevisto se torna critério do fazer e de pensar (OLIVEIRA-FORMOSINHO, 2007, p. 21).

Embora a ampliação das experiências infantis seja reconhecida como prioridade no trabalho com as crianças pequenas, a unidade, ainda hoje, não garante condições plenas para que isso se concretize. 
Há, no planejamento das professoras, espaço para a realização de projetos com as crianças: no período da manhã, a dupla trabalha o "projeto animais". Tal projeto surgiu a partir da chegada de um peixinho que a turma ganhou da família de uma criança. O tema é trabalhado com a turma, semanalmente, às terças-feiras. Durante o período da tarde, existem experiências contínuas nas "áreas de interesse". Ou seja, existem experiências interessantes ocorrendo nos dois períodos, mas elas não se relacionam, são experiências pontuais e isoladas. Certamente, tais experiências ficariam muito mais ricas se pudessem ser vividas de forma mais contínua, estabelecendo uma ponte entre as ações das professoras dos dois períodos. O que se deseja defender é que o 'projeto animais', desencadeado no período da manhã, poderia compor atividades correlatas à tarde, por exemplo. Os projetos e as atividades em "áreas de interesse" deveriam compor um todo experiencial para as crianças, beneficiando a qualidade de suas experiências.

Como sustenta Oliveira-Formosinho (2011), a virtude do projeto é criar um contexto que interpela as crianças a fazerem escolhas para desenvolvê-lo, além de implicar continuidade e interatividade da experiência.

\subsection{Registros no Diário de Campo da Pesquisadora}

Por meio desta fonte, buscou-se identificar o quanto os planejamentos se revelam nas ações, dando-se especial atenção à variedade e expressividade das experiências vividas pelas crianças,tendo como base, mais uma vez, os critérios de continuidade e interação propostos por Dewey.

O trabalho desenvolvido no CEI em que se deu a pesquisa, a exemplo do que ocorre em outros CEIs da rede municipal, pauta-se em uma rotina diária, determinada de acordo com os tempos institucionais. Embora não conste em qualquer documento legal, há uma patente uniformidade entre as unidades na constituição desses tempos. A rotina geral prevê horários para: acolhimento, alimentação, sono, saída, seguida por todos os agrupamentos do CEI. Ademais, há uma rotina própria de cada agrupamento construída internamente por cada grupo de professoras. Para facilitar a compreensão do leitor quanto à rotina vivida no espaço institucional pelas quatro professoras e pelo grupo de crianças do MGI-A/B, apresenta-se um breve recorte, contendo um dia de observação da pesquisadora, registrado em diário de campo, exposto sucintamente na tabela 8 . 
Tabela 8 - Rotina do CEI

\begin{tabular}{|c|c|c|c|}
\hline HORÁRIO & SEGMENTO & LOCAL & ATIVIDADE \\
\hline $8 \mathrm{~h} 00$ às $8 \mathrm{~h} 30$ & MGI & sala & acolhida \\
\hline $8 \mathrm{~h} 30$ às $8 \mathrm{~h} 45$ & MGI & Banheiro /refeitório & Higiene/café \\
\hline $8 \mathrm{~h} 45$ às $9 \mathrm{~h} 00$ & MGI & Sala & $\begin{array}{c}\text { Chamadinha/roda de } \\
\text { conversa }\end{array}$ \\
\hline $9 \mathrm{~h} 00$ às $9 \mathrm{~h} 30$ & MGI & Parque & Brincar livre \\
\hline $9 \mathrm{~h} 30$ às $9 \mathrm{~h} 40$ & MGI & Banheiro /refeitório & Higiene e suco \\
\hline $9 \mathrm{~h} 40$ às $10 \mathrm{~h} 30$ & MGI & Sala & Atividades em sala \\
\hline 10h30 às 10h45 & MGI & Sala/banheiro & Roda /higiene \\
\hline $10 \mathrm{~h} 45$ às $11 \mathrm{~h} 00$ & MGI & Refeitório & Almoço \\
\hline $11 \mathrm{~h} 00$ às $11 \mathrm{~h} 30$ & MGI & Banheiro/sala & $\begin{array}{c}\text { Higiene /preparação para o } \\
\text { sono }\end{array}$ \\
\hline $11 \mathrm{~h} 30$ às 14h00 & MGI & Sala & Sono \\
\hline $14 \mathrm{~h} 00$ às $14 \mathrm{~h} 30$ & MGI & Sala/banheiro & $\begin{array}{c}\text { Organização da sala após o } \\
\text { sono/higine }\end{array}$ \\
\hline $14 \mathrm{~h} 30$ às 14h45 & MGI & Refeitório & Lanche da tarde \\
\hline $14 \mathrm{~h} 45$ às $15 \mathrm{~h} 00$ & MGI & Sala & Roda de conversa \\
\hline 15 h00 às 15 h30 & MGI & Parque & Brincar livre \\
\hline $15 h 30$ às $16 h 15$ & MGI & Sala & Atividades em sala \\
\hline $16 \mathrm{~h} 20$ às $16 \mathrm{~h} 50$ & MGI & Banheiro /Refeitório & Higiene/Jantar \\
\hline $16 h 55$ às 17h00 & MGI & Banheiro/sala & $\begin{array}{c}\text { Higiene/troca/organização } \\
\text { para saída }\end{array}$ \\
\hline 17h00 às 17h20 & MGI & Sala & $\begin{array}{c}\text { Roda de conversa ou de } \\
\text { leitura }\end{array}$ \\
\hline $17 \mathrm{~h} 30$ às $18 \mathrm{~h} 00$ & MGI & Sala & Saída/jogos/leitura \\
\hline
\end{tabular}

Ao longo das observações notou-se que apesar de haver na instituição uma linha do tempo que organizava a rotina de higiene e alimentação, horários de parque e horários em sala, as professoras conseguiam dinamizar tal rotina, de forma a 
proporcionar às crianças momentos livres, momentos de leitura, rodas de conversa, brincadeiras nas áreas de interesse, bem como o desenvolvimento de projetos da turma.

Para receber as crianças, as professoras organizavam os espaços da sala de forma que, $\log$ o na acolhida, elas pudessem fazer escolhas de atividades. Em uma manhã de observação, foi possível perceber essa organização. A professora disponibilizou livros na área de leitura e jogos de montar do outro lado da sala. Essa atitude facilitou a recepção das crianças, uma vez que, ao chegar, elas iam tirando suas agendas das mochilas, guardando as mesmas e dirigindo-se ou para a área de leitura ou para os jogos de montar. Enquanto as crianças que já haviam chegado conversavam e interagiam nessas duas áreas, as duas professoras recebiam as que estavam chegando. Após a acolhida, a turma organizava-se para higiene. Nos momentos de higiene as professoras orientavam as crianças quanto ao uso do sabonete, água e ao próprio uso do vaso sanitário.

Após a recepção das crianças, as professoras organizavam-se para que as crianças pudessem ajudar na arrumação da sala enquanto faziam a higiene para o café. No momento do café, as crianças sentavam-se todas juntas em uma grande mesa localizada do lado esquerdo do refeitório. Aquele era o lugar da turma no refeitório (durante o período da manhã). Notava-se que as crianças já sabiam onde deveriam sentar-se. As professoras entregavam o pão e o leite às crianças. Durante o café, as crianças conversavam entre si e também com as professoras, que incentivavam aquelas que resistiam a comer. Após alimentarem-se, as crianças devolviam as canecas e utensílios que haviam utilizado pela janelinha de acesso à cozinha.

No espaço do parque havia um grande tanque de areia, casinhas de madeira, uma área coberta em que ficavam estacionados os triciclos, além de um grande recipiente com baldes pazinhas e objetos para brincar na areia. Havia também três mesas com cadeiras, bem como uma pia com três torneiras.

Nos momentos de brincar no parque, tanto no período da manhã como no período da tarde, as crianças iam sozinhas, em pequenos e grandes grupos, criavam suas brincadeiras, escolhiam instrumentos para se divertir na areia e transitavam por todo o espaço explorando os brinquedos dispostos. Enquanto as crianças brincavam, as professoras transitavam pelo espaço do parque, intervindo quando surgiam conflitos ou mesmo quando consideravam que as crianças estavam em risco. Havia, nos dois 
períodos, momentos destinados ao brincar livre (nas áreas internas e externas do CEI) e momentos que as professoras nomeavam como "atividades direcionadas", como pinturas, explorações sonoras, entre outras.

No almoço, as crianças não se serviam. Em fila, pegavam seus pratos já prontos na janelinha do refeitório e direcionavam-se à mesa da turma. As professoras incentivavam-nas a comerem e auxiliavam as mais resistentes. Durante o jantar, as crianças sentavam-se em outra grande mesa só que do lado direito do refeitório. Os pratos eram entregues quando elas já estavam sentadas à mesa. As professoras sentavam-se com as crianças e, mais uma vez, ajudavam aquelas que se recusavam a comer. Nesses momentos (almoço e jantar) as crianças conversavam entre si e também com as professoras. Ao sentirem-se satisfeitos, limpavam o prato descartando os restos de comida. Havia sobre a mesa na altura das crianças duas bacias: uma para colocar o prato e outra os talheres. No período da tarde, na medida em que iam terminando o jantar, as crianças se encaminhavam para sentar nos degraus da escada que dá acesso ao $2^{\circ}$ andar do prédio. As professoras então se organizavam de tal sorte que uma acompanhava as crianças que permaneciam no refeitório e a outra supervisionava o grupo na escada. Enquanto esperavam, as crianças conversavam, cantavam, faziam "hola". Numa dessas ocasiões em que as crianças cantavam, a professora I me explicou que, naquele momento de espera, elas experimentavam as propriedades dos sons com as crianças: cantavam alto, baixo, lento, rápido.

Para o momento do sono, que se iniciava ainda no período da manhã, as crianças colaboravam com a organização da sala para dormir. Os colchões eram colocados no chão por um adulto, enquanto as crianças pegavam seu kit com lençol, tiravam os sapatos e se trocavam com a ajuda das professoras. Após o sono, já no período da tarde, o movimento era parecido, meninas e meninos colaboravam, dobrando os lençóis, organizando os colchonetes, colaboravam com as professoras e entre si. Em muitos momentos, foi possível perceber as crianças ajudando-se mutuamente a colocar o tênis, meia, amarrar cadarço. As professoras encorajavam as crianças a ajudarem na organização da sala, a irem sozinhas ao banheiro, mas sempre sob a supervisão do adulto.

Era no momento do sono, mais precisamente às $13 \mathrm{~h} 00$, que havia a troca de turnos: as professoras da manhã encerravam o expediente enquanto as professoras da 
tarde davam início ao delas. Nesse momento, havia tempo somente para que ambas as duplas se cumprimentassem. Caso alguma das professoras conseguisse, por algum motivo, chegar um pouco mais cedo ou sair um pouco mais tarde, havia uma rápida conversa sobre a turma. Contudo, no período de observações, não aconteceu nenhum encontro reunindo as quatro professoras.

No período da tarde, em quase todos os dias em que se realizaram observações, as crianças puderam brincar livremente nas áreas de interesse organizadas no espaço da sala: casinha, médico, sorveteiro entre outras. Durante a manhã, essas áreas não eram montadas. Vale lembrar que os objetos e materiais que compunham essas áreas ficavam dispostos no espaço da sala diariamente, mas só eram montadas e organizadas durante o período da tarde. É preciso destacar uma condição favorável observada especificamente na turma acompanhada no estudo: número de crianças era um número pequeno para o espaço físico disposto, o que proporcionava maiores possibilidades organizativas da turma.

No momento de saída, o processo era parecido com os momentos de acolhida. Organizava-se algumas vezes uma roda de leitura em que a professora contava histórias às crianças; concluída a história, o espaço era reorganizado com áreas para jogos, onde as crianças podiam interagir enquanto esperavam seus familiares. Em outros momentos, as professoras brincavam e cantavam com as crianças. Na chegada das famílias, enquanto uma professora interagia nas áreas com as crianças, a outra recebia os pais e entregava a criança.

Com o intuito de ilustrar as ações que ocorrem em cada um dos períodos, para que se possa lançar um olhar analítico sobre as experiências vivenciadas pelas crianças, optou-se por trazer fragmentos de sessões de observação.

\subsubsection{O projeto animais}

O "projeto animais" é desenvolvido somente no período da manhã. Como foi dito, ele teve início com a doação de um peixinho pelos pais de uma criança da turma, para o qual foi providenciado um aquário pelas professoras da manhã. Junto com a turma, elas escolheram um nome para o peixinho e, mediante questões colocadas pelas crianças, foram juntas construindo o "projeto animais". 
O projeto fazia todo o sentido para a turma e era possível notar isso facilmente na fala das próprias crianças, uma vez que essas revelavam espontaneamente as aprendizagens que já haviam adquirido, sobretudo sobre os peixes, Em certa ocasião, Vivi pega um livro que continha imagens de baleias, golfinhos e tubarões, aproxima-se da professora P. e diz: "Esse é o golfinho”. Zé se aproxima de Vivi e ambos dirigem-se para perto do espelho. Vivi se dirige a Zé e diz: "Olha Zé! Olha o tubarão aqui. Ele faz susto, abre a boca, morde, tem dente grandão”.

Nota-se o quanto a temática faz sentido para a turma, contudo, o trabalho com esse projeto, ocorre somente no período da manhã, de modo que as crianças não podem ampliar essas experiências no período da tarde. Ora, não seria possível inserir nas áreas de interesse um espaço em que houvesse miniaturas de animais, sobretudo peixinhos, uma vez que esse é um assunto do interesse das crianças? Certamente, se as professoras pudessem ter a dimensão exata do que está sendo explorado pelas crianças, quais são os interesses e as questões que elas trazem do outro período. No entanto, isso só seria viável se houvesse uma boa comunicação entre as duplas, de modo que o trabalho não fosse realizado de forma fragmentada entre a manhã e a tarde, mas que fosse pensado para o dia inteiro. Ou mesmo se houvesse tempos e espaços no CEI que garantisse o registro efetivo do trabalho realizado com as crianças.

Como assevera Pinazza (2014), existe uma pluralidade de propostas de inserção do trabalho com projeto nas práticas educacionais correntes, contudo, tais propostas só podem ser consideradas legítimas se estiverem assentadas nos conceitos de educação pela experiência e reflexão, configurando o que Dewey chama de uma ocupação construtiva. Nas palavras de Pinazza (2014, p. 42),

Entre as ocupações construtivas encontram-se os jogos e brincadeiras, assim como trabalhos de diferentes naturezas com vários materiais, em que se inclui o trabalho de projetos, envolvendo o exercício dos sentidos e atividades de movimento. Dewey distingue jogo e trabalho, destaca a relevância de ambos e não opõe uma atividade a outra.

Ainda nas palavras da pesquisadora, tais ocupações não são atividades quaisquer oferecidas às crianças para mantê-las distante das travessuras e do ócio, também não se configuram enquanto exercício de treinos mecânicos.

Para Dewey, as ocupações são educativas quando representam atividades que promovem experiências inteligentes com fatos, instrumentos e objetos do ambiente, em uma organização progressiva 
de informações e conceitos, por meio de experimentação (PINAZZA, 2014, p.43).

Fica claro que os projetos ou ocupações propostas por Dewey devem seguir uma organização progressiva, em que as crianças possam avançar em sua pesquisa, dando continuidade às experiências.

Se o "projeto animais" apresentava-se como uma constante no período da manhã, por sua vez, no período da tarde, a sistematização de experiências concentravase nas áreas de interesse, sistematização que não era observada no período da manhã.

\subsection{2 Áreas de interesse, uma constante durante o período da tarde}

No período da tarde, as crianças constantemente interagiam nas áreas de interesse organizadas pelas professoras. Nas rodas de conversa, as professoras faziam uma votação para que as crianças pudessem escolher entre ir ao parque ou permanecer na sala e brincar nas áreas de interesse. Esse momento costumava ser aquele em que as professoras brincavam com as crianças, mas também era o tempo em que as crianças brincavam livremente e criavam brincadeiras.

Na passagem a seguir, ilustra-se um momento de organização dos trabalhos em áreas de interesse.

Ao entrar na sala, as crianças sentam-se diante do tapete, fazendo uma roda. ${ }^{19} \mathrm{~A}$ professora $\mathrm{O}$ explica:

- Lembra que desenhamos e dançamos ao mesmo tempo com aquelas músicas diferentes? Então, a gente pensou em fazer isso hoje. O que vocês acham?

Sarah:

- Legal!

Thiago:

- É legal.

Professora O:

- Dá pra fazer duas coisas. Dá pra fazer isso e brincar nos cantinhos.

Ingrid, Henrique e Matheus gritam:

\footnotetext{
${ }^{19}$ Retirado do Diário de Bordo da pesquisadora.
} 
- Eu quero brincar de cantinho!

Professora O:

- Vocês preferem os cantinhos. Mas ainda dá pra gente fazer outra coisa. A Duda e a professora I. tinham pensado em desenhar, dançar, mas também vocês lembram daquele lugar que a gente brincou lá fora?

Duda:

- Eu lembro.

Professora O:

- Então tá! De cantinho a gente vai brincar. E depois do cantinho, a gente vai dançar ou brincar lá fora.

Sarah:

- A gente quer brincar de cantinho.

Professora O:

- Então tá bom. Então vamos brincar no cantinho.

No fragmento acima, foi possível perceber que embora houvesse uma proposta por parte da professora, as crianças persistiram na decisão de brincar nas áreas de interesse. Essa situação demonstra também o interesse das crianças em explorar essas áreas. As áreas de interesse suscitavam as mais diversas brincadeiras.

Nesse ambiente, a criança pode brincar de forma livre, quando inicia uma brincadeira por conta própria ou participa de uma brincadeira iniciada pela professora. Para uma educação de qualidade, a criança precisa tanto de brincadeiras livres para tomar iniciativa, como de outras orientadas pelas professoras para aprender coisas que não sabe (KISHIMOTO, 2013, p.10)

Nas áreas de interesse, as crianças sempre retomavam as brincadeiras. Havia uma garotinha que semanalmente retomava sua brincadeira de princesa, e a cada vez inseria elementos diferentes. Inicialmente, ia a bailes, na outra semana já estava indo ao salão de cabelereiros para, só depois, colocar o vestido e ir ao baile. As professoras, nesse momento, brincavam com as crianças, observavam suas ações nas áreas. E isso se revelava no planejamento da semana seguinte, seja na providência de novos materiais, seja na organização das áreas de forma a suscitar novas brincadeiras. Essas ações revelam uma faceta do currículo que nem sempre está posta no plano das professoras. Sobre isso, escreve Abuchaim (2012, p.22), 
[...] o currículo é muito mais do que o prescrito em documentos oficiais, ele envolve tudo o que acontece no processo educativo, incluindo o plano dos professores e sua execução, por isso é uma construção social, historicamente circunscrita e cotidianamente transformada.

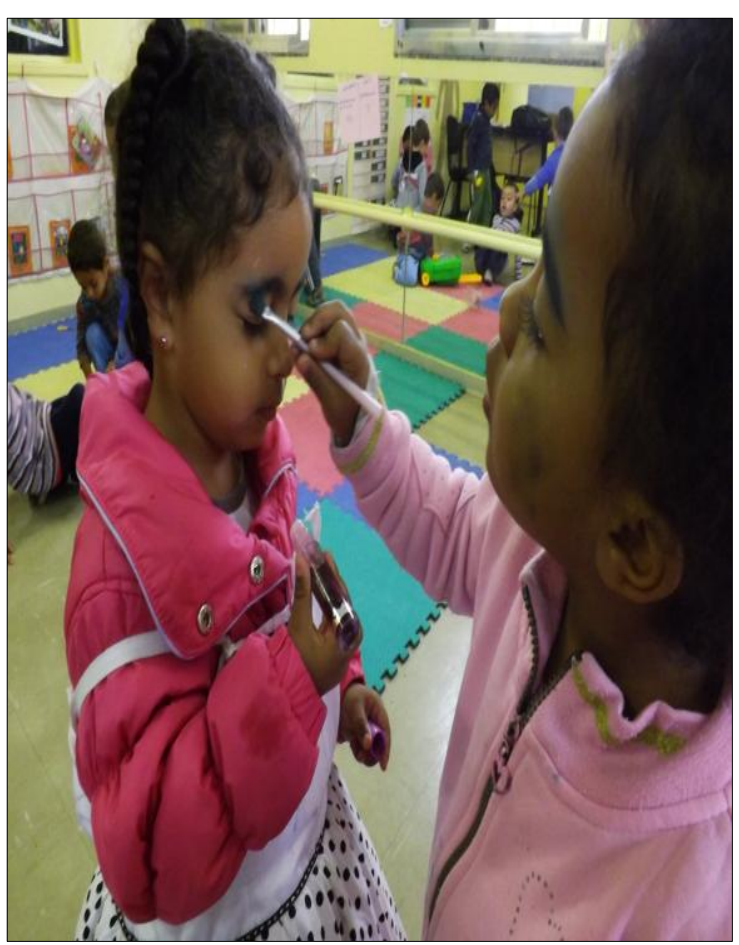

$\mathrm{Na}$ imagem, uma das meninas faz a maquiagem da outra na área da fantasia. É possível perceber que elas vivenciam momentos de colaboração, interação e concentração. Nessa área havia materiais como maquiagem, esmaltes, fantasias, sapatos, entre outros. A brincadeira das meninas continua quando a criança que está sendo maquiada veste-se de princesa para ir a uma festa.

Fotografia 13 - Meninas se maquiando. 


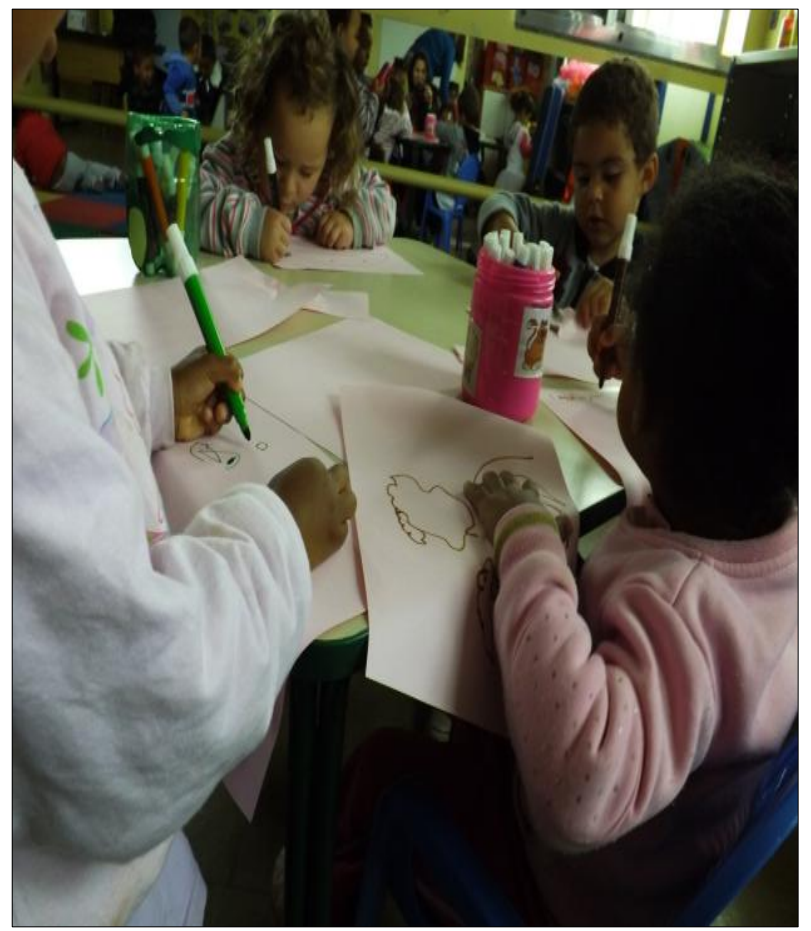

Nesta imagem é possível observar as crianças criando seus desenhos de forma livre, No momento seguinte, elas buscaram tesouras para recortar o que haviam desenhado. Observava-se que os materiais disponíveis permitiam às crianças desenhar com ou sem moldes, pintar e em seguida recortar seu desenho, pois nesta área havia materiais como tesoura, cola, canetinha, giz de cera, papel, moldes para desenhar.

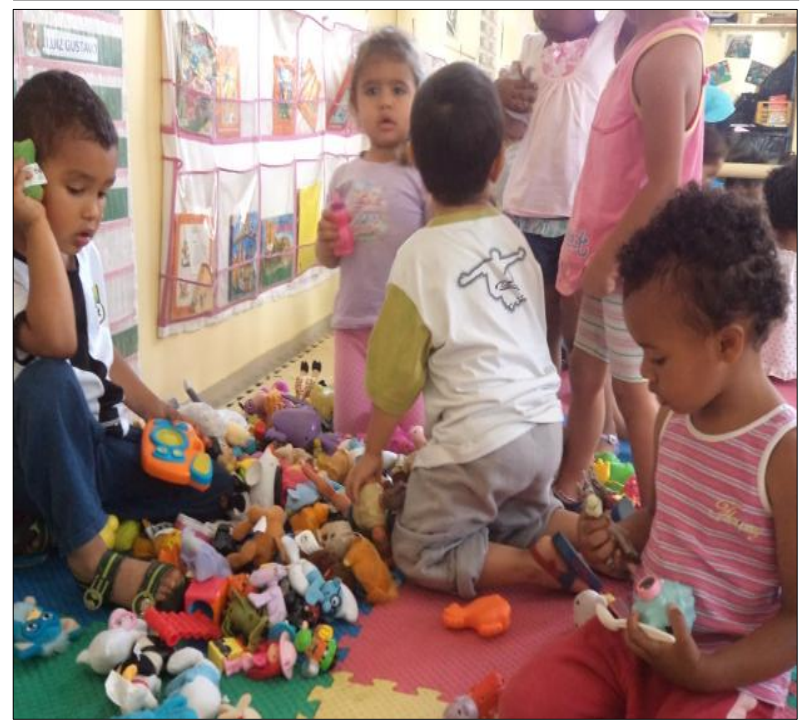

$\mathrm{Na}$ área de construção ficavam brinquedos como bonecos, jogos de montar, carrinhos entre outros. Na imagem, meninos e meninas vivenciam experiências distintas, envolvendo exploração de diferentes materiais e criando situações lúdicas como, por exemplo, falar ao telefone.

Fotografia 14 - Crianças desenhando.

Fotografia 15 - Crianças brincando.

Durante muitas sessões de observação foi possível perceber como as crianças, sempre acompanhadas pelo olhar das professoras, envolviam-se nas áreas de interesse, . Isso acontecia regularmente no período da tarde. As professoras se preocupavam em estimular as crianças a interagirem nas áreas de interesse pelo menos duas vezes por semana. Desta forma, ainda que de forma tímida, a brincadeira, sob o olhar atento do adulto, era incorporada ao planejamento pedagógico. Nas palavras de Kishimoto (2013), 
a brincadeira é essencial para a construção da identidade da criança, por isso é imprescindível que ela esteja presente no cotidiano das creches e pré-escolas. Nesse sentido,

Para ampliar a qualidade do brincar, é essencial pensar nos acessórios que compõem a diversidade dos temas das brincadeiras, organizar o cenário, distribuir, no tempo e no espaço, as áreas de experiências lúdicas das crianças e propiciar constantes interações (entre crianças e entre adulto e crianças) (KISHIMOTO, 2013, p.4).

Pode-se dizer que o brincar estava presente nos dois períodos, contudo o brincar sob o olhar atento e orientado do adulto, em espaços cuidadosamente preparados com esse fim, o que se expressava, por exemplo, na riqueza de materiais das áreas de interesse, somente ocorria no período da tarde.

Havia nos dois períodos momentos em que meninas e meninos podiam brincar livremente, no parque ou nas demais áreas externas do CEI. Esses momentos são tratados a seguir.

\subsubsection{Os Momentos de Brincadeiras Livres}

Os momentos livres vivenciados pelas crianças se mostravam como experiências prazerosas em que predominava a interação entre meninos e meninas, a inventividade e a alegria. Tais oportunidades ocorriam tanto no período da manhã como no período da tarde. As professoras entendiam que as crianças deveriam ter liberdade para brincar, criar e recriar suas próprias experiências. No entanto, esses momentos não eram aproveitados no planejamento. Apresentam-se, a seguir, dois exemplares dessas brincadeiras com o intento de ilustrar melhor o esse ponto.

\subsubsection{A brincadeira do Cachorro ${ }^{20}$}

$\mathrm{Na}$ área coberta do parque, estão disponíveis motocas, triciclos, baldes e pazinhas para brincar com areia. Eduardo pega um balde e coloca na cabeça como se fosse um chapéu. A turma do B-II também está nesse espaço. Percebo Sarah, Ingrid e Vitor com algumas folhas em um balde. Com o uso da pazinha, eles mexem as folhas como se fosse comida.

Ingrid oferece para Marcos:

- Quer um pouquinho?

Vitor despeja o que tem no balde da Ingrid. Ela pergunta:

\footnotetext{
${ }^{20}$ Trecho retirado do Diário de Bordo da pesquisadora. Período da manhã 09/09/2013
} 
- Cê não quer mais? Quer um pouquinho?

Ingrid coloca um pouco no balde de Vitor, dizendo:

- Tó, só um pouquinho!

Ingrid e Vitor estão em pé, mexendo as folhas na bacia. Sarah está agachada ao lado deles. Ingrid abaixa-se e joga algumas folhas no chão para Sarah, dizendo:

- Pega vai!

Agora que percebi! Sarah é o cachorrinho. As crianças estão envolvidas em um faz de conta em que Sarah é um cachorrinho, Vitor e Ingrid são seus donos. Ingrid fala para o Vitor:

- Olha ai, eu dei uma comidinha para o cachorrinho!

Ingrid e Vitor dão uma volta pelo espaço e param perto de um triciclo.

Ingrid:

- Vitor! Coloca aqui. Convidando-o para vir mexer a "comidinha" perto dela.

Os dois em pé mexem a comida.

Thiago se aproxima de Ingrid com o triciclo.

Ingrid fala para ele:

- Olha a buzina, a buzina faz "bibi"!

Ingrid e Vitor voltam ao local que Sarah está ainda de joelhos imitando um cachorrinho.

Vitor coloca o balde perto de Sarah. Vivi joga a "ração" e Sarah finge comer.

Ingrid pega o triciclo para dar uma volta. Sarah segue atrás ainda como cachorrinho atrás do dono. Sarah fez todo o percurso atrás de Ingrid.

Ingrid pergunta:

- Quer?

Joga as folhas para Sarah como se fosse ração.

Vivi se aproxima de Sarah e Ingrid, imitando cachorrinho também.

Ingrid 'alimenta' as duas.

Elas não conversam. Compreendem o papel que estão representando no jogo. $\mathrm{O}$ cachorro não fala.

Ingrid joga a ração e fala: 
- Vai, vai!

Vivi dá voltas atrás de Ingrid. Vivi e Sarah (as cachorrinhas) deitam no colo de Ingrid para que ela as acariciem.

Ingrid diz:

- Que foi? (fazendo carinho em Vivi e dando-lhe a ração na boca, como se fosse uma cachorrinha mesmo).

Ingrid faz brincadeiras com Sarah jogando a comida para ela pegar. Sarah e Vivi (as cachorrinhas) não falam com Ingrid em momento nenhum.

Ingrid arruma a ração nos potes (tampas de potes) para elas comerem.

Vivi agora é a nona da cachorrinha também.

Só há uma cachorrinha, Sarah.

Vivi coloca ração para a cachorrinha e pergunta:

- Quer?

Ingrid ensina a cuidar.

- Dá dessa daqui pá ela não come ó.

Sarah (a cachorrinha) não aceita.

Ingrid:

- É porque essa não come ó. 


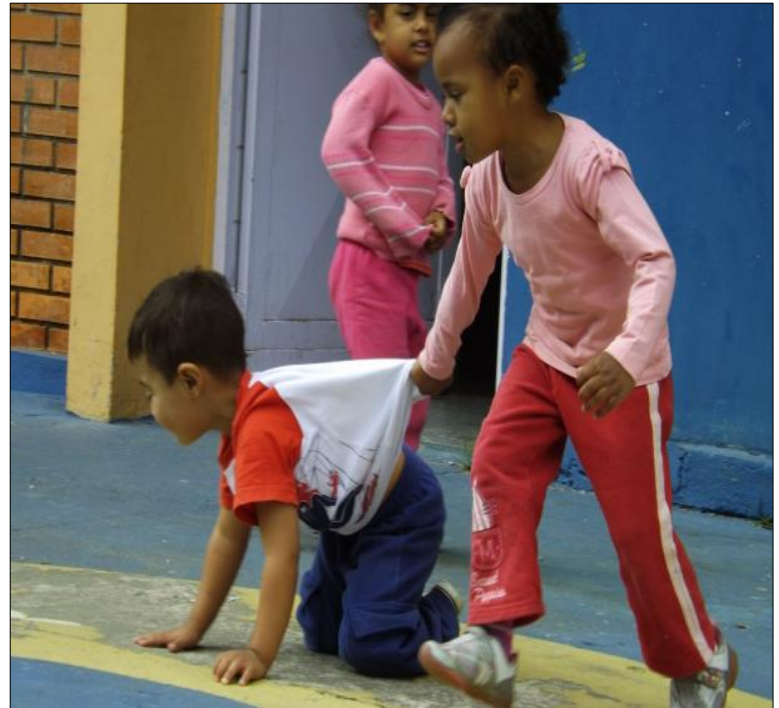

Fotografia 16 - Crianças brincando.

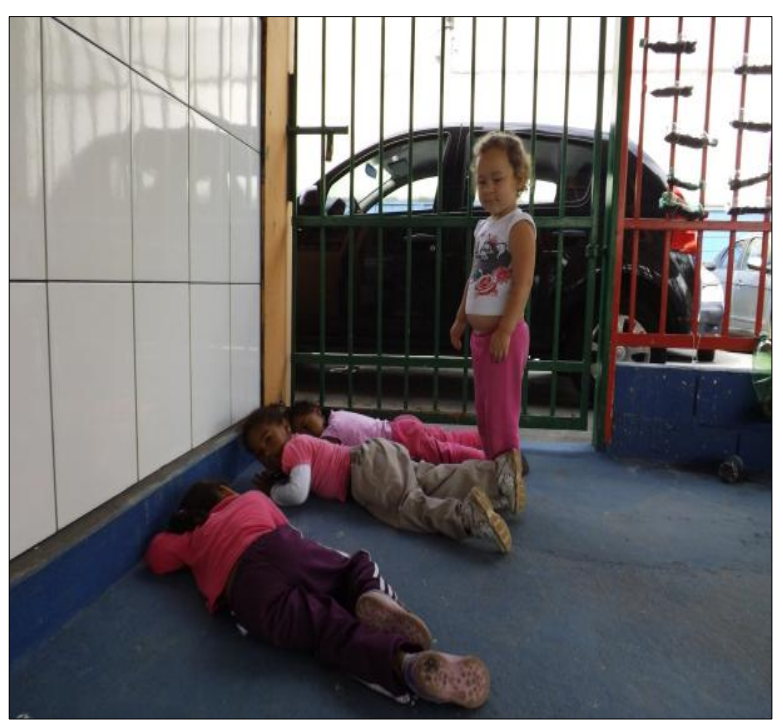

Fotografia 17 - Crianças brincando.
Ao brincarem livremente nos espaços externos as crianças podem se lançar em uma série de experiências imaginárias, representando e experimentando papeis distintos. Observa-se também que, nesses momentos, as crianças revelam conhecimentos adquiridos na vida cotidiana, na família e na escola. Esse momento sustenta não só aprendizagens no âmbito da linguagem oral, uma vez com o desenrolar da brincadeira as crianças vão narrando os acontecimentos, como também aprendizagens referentes ao convívio social, ao cuidado com o outro e com o meio.

Esses momentos mostravam-se riquíssimos, fornecendo importantes pistas para o planejamento das experiências e vivências propostas às crianças. Um olhar atento e observador permite descobrir o que as crianças já sabem, bem como o que gostariam de saber e outras demandas.

Para Kishimoto (2013), ao observar a criança, pode-se compreender que cada uma é diferente de outra, tanto na idade como em sua forma de falar, de pensar, de se relacionar com outros e de gostar de um brinquedo e não de outro. 
A brincadeira de cachorrinho continua ${ }^{21}$.

Aproximo-me de Duda, Dhara, Ingrid e Sarah, que estão brincando no parque.

Duda está com alguns baldinhos de água e lama.

Pergunto à Duda o que ela está fazendo.

Duda:

- Tô fazendo um bolo.

Sarah:

- Eu tô brincando de cachorrinho (mesma brincadeira de duas semanas atrás)

Sarah e Ingrid se afastam e vão para outro canto. Vou atrás para observar a brincadeira delas.

Ingrid:

- Esse é meu cachorrinho.

Pergunto o nome desse cachorrinho.

Ingrid:

- Não sei. Não tem nome. É Sarah. Ele come a ração.

Sarah permanece sentada (como cachorrinho). Ingrid percebe que estou fazendo anotações. Aproxima-se de mim e vem dizer o que está fazendo:

- A gente vai passear. Olha o porquinho dela (me mostra o porquinho de brinquedo).

Sarah deita-se no colo de Ingrid, que a acaricia como se fosse um bichinho.

Ingrid pega algumas pás e um copinho.

- Tô me maquiando. Vou maquiar o cachorrinho para passear.

Sarah vai atrás de Ingrid, andando normalmente e não como cachorrinho. Elas vão para o outro lado do parque.

Esses momentos revelam o quanto as crianças são capazes e inventivas e, além disso, como realizam vivências intensamente. O olhar atento e uma ação oportuna do adulto poderiam desencadear outras experiências e consequentemente novas aprendizagens.

\footnotetext{
${ }^{21}$ Retirado do diário de Bordo da Pesquisadora. Observação realizada em 02/10/2013
} 
No entanto, não havia um olhar atento para tais momentos, talvez por ser "livre" para a criança. É importante, sim, esse momento livre, mas é preciso compreendê-lo como um momento de escuta daquilo que a criança quer contar aos adultos. Como sustenta Oliveira-Formosinho (2011) na Pedagogia-em-Participação, é imprescindível o olhar atento do adulto, para que esse possa mediar a agência da criança que aprende e o contexto de aprendizagem. Em tal processo, as interações criança/adulto são essências. Nesse sentido, o planejamento a partir das crianças exige escuta e observação atenta nos diferentes tempos e espaços. Garantindo, sobretudo, que meninas e meninos tenham o direito à brincadeira legitimado no planejamento e no dia-a-dia,.

Gobbi (2013) fala da necessidade de tempos e espaços para brincar na educação infantil. É necessário acreditar na potência das crianças, concebendo-as como construtoras de culturas infantis que, ao seu modo, são capazes de propor e elaborar no tempo da infância, e a partir dele, suas formas de ser e estar no mundo. Por outro lado,

Cabe propor e organizar formas organizativas em que estejam presentes o "estar junto", a possibilidade de contemplar relações voltadas à curiosidade, as ricas experiências, as inventividades, de modo que as culturas estejam presentes (GOBBI, 2013, p.43).

Sendo assim, o brincar livre da criança torna-se fonte de inspiração para o adulto, desde que lhe seja dada devida atenção para que, dessa forma, propostas novas e expressivas experiências sejam feitas.

\subsubsection{Saltos sobre o escorregador}

Em uma das sessões de observação, as crianças no espaço do solário, criaram uma brincadeira de pular. Nessa brincadeira, os pequenos vivenciavam desafios motores inusitados sob o olhar atento e encorajador das professoras. 


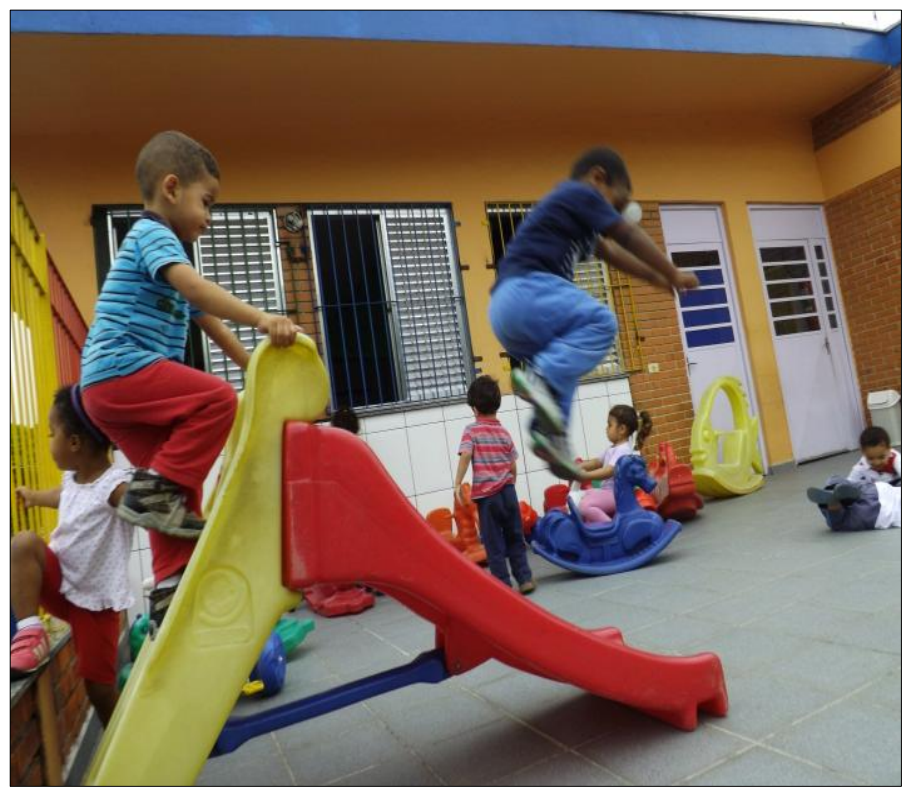

A imagem retrata momentos de brincadeira livre na área externa do CEI em que as crianças reinventam maneiras de brincar no escorregador. Escorregar somente, tornou-se algo pouco desafiador, desta maneira criam-se novos desafios motores, como saltar sobre a extensão do brinquedo.

Fotografia 18 - Crianças saltando.

Enquanto as crianças saltavam sobre o escorregador, notava-se o olhar atento das professoras, preocupadas com eventuais machucados, contudo, não tentaram interromper a brincadeira. As crianças permaneceram saltando sobre o escorregador o quanto quiseram. Em alguns momentos, apesar da preocupação, as professoras as encorajavam a saltar mais alto.

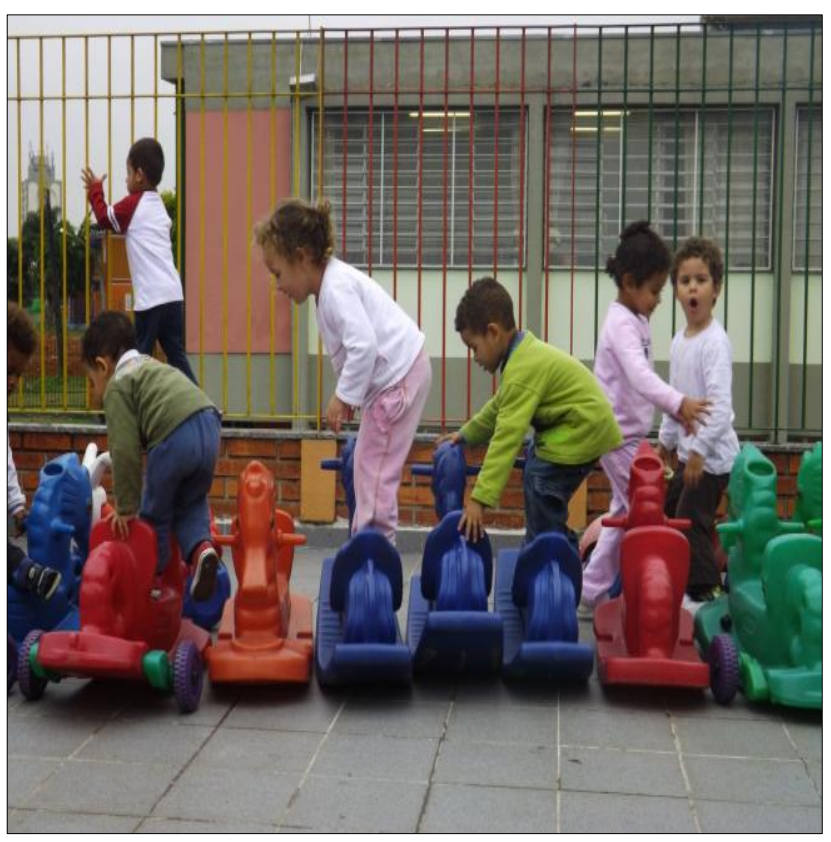

Fotografia 19 - Crianças brincando.

\begin{tabular}{l} 
Nesta imagem, as crianças \\
realizam uma trilha sobre os \\
cavalinhos. A capacidade \\
inventiva das meninas e meninos \\
se manifesta quando lhes é \\
conferido o espaço necessário para \\
a invenção. Nesse momento, as \\
crianças puderam construir \\
aprendizagens relacionadas à \\
organização de espaços para \\
brincar e também à classificação, \\
uma vez que dispuseram os \\
cavalinhos segundo suas cores e \\
formas. Enquanto andavam sobre \\
eles ainda demonstravam \\
habilidades matemáticas, fazendo \\
a contagem dos cavalos. \\
\hline
\end{tabular}

Nesta imagem, as crianças realizam uma trilha sobre os . inventiva das meninas e meninos se manifesta quando lhes é conferido o espaço necessário para a invenção. Nesse momento, as crianças puderam construir aprendizagens relacionadas à
organização de espaços para brincar e também à classificação, uma vez que dispuseram os cavalinhos segundo suas cores e formas. Enquanto andavam sobre eles ainda demonstravam a contagem dos cavalos. 
Embora divertidas e prazerosas para as crianças, essas experiências não podem ser identificadas como expressivas segundo Dewey, ${ }^{22}$ uma vez que ocorriam de maneira pontual, não desencadeavam outras experiências, tampouco eram aproveitadas no planejamento de forma a ampliar o que estava sendo vivenciado pelas crianças. Essas ações educativas, nesse aspecto, diferenciam-se daquelas promovidas nas "áreas de interesse" ou no "projeto animais", nos quais havia ainda uma pequena condição de continuidade, o mesmo não se pode dizer dos momentos em que as crianças estão nessas atividades mais livres, que não suscitam elementos de ação para planejamentos futuros das professoras.

Dessas constatações, é possível concluir que as professoras poderiam extrair maior proveito das realizações das crianças em favor de um planejamento mais orgânico, para cada um dos períodos e para os considerados conjuntamente. Isso garantiria maior fluidez no âmbito das práticas curriculares e, por conseguinte, asseguraria experiências de aprendizagens qualitativamente mais expressivas.

Como escreve Pinazza (2014), segundo Dewey, para as experiências de aprendizagem serem de fato expressivas precisam conferir à criança o lugar de sujeito investigador das experiências, não podem vir em forma de ordens, modelos ou soluções propostas pelo adulto, tirando da criança da possibilidade de realizar suas observações, elaborar suas próprias hipóteses, enfim, lançar-se à investigação por si mesma. Desta maneira, para que as ocupações ou projetos sejam verdadeiramente educativos, devem ter início nos desejos e impulsos e primeiras sugestões das crianças (PINAZZA, 2014).

\section{Conclusões Possíveis}

Todas as ponderações realizadas ao longo deste capítulo demonstram que, por uma série de fatores, não há um planejamento comum entre as quatro professoras e que esse é um elemento que priva as crianças de experiências de educação expressivas pautadas na continuidade e na interação.

Como constatou Abuchaim (2012), não se proveem horas de planejamento para as professoras. O planejamento é contado como hora remunerada, mas deve ser feito em casa. E, mesmo quando realizado na unidade educacional, é feito solitariamente.

\footnotetext{
${ }^{22}$ Em referências aos conceitos postos por Dewey.
} 
Portanto, não há espaço no CEI para comunicação entre as duplas de professoras, e nem mesmo dessas com as gestoras. Além disso, a organização institucional do CEI não permite que as duplas possam planejar juntas, ou mesmo tomar parte, de fato, no cotidiano vivido pelas crianças em cada período.

Por fim, o conjunto de evidências fornecidas pelas diferentes fontes de dados consideradas nesse estudo conflui plenamente. Os dados advindos das entrevistas, do exame do Projeto Político Pedagógico, da análise dos planos de trabalho e registro das professoras junto à observação das práticas, revelam a descontinuidade e fragmentação das experiências vividas pelas crianças.

Analisando as práticas cotidianas presentes na instituição, percebe-se uma preocupação em dinamizar o dia-a-dia no CEI. Contudo, não há um efetivo olhar para as pistas que meninas e meninos podem oferecer à construção de um planejamento pautado na participação. Como bem pontua Abuchaim (2012), planejar com a participação desses atores requer das professoras uma postura paciente, uma disponibilidade para mudar seu planejamento a partir das demandas do grupo, uma capacidade apurada para a escuta de meninas e meninos. Tais ações são desafiadoras, pois não basta somente ter a intenção e o desejo de fazer, é preciso antes de tudo, saber como fazer. Embora as professoras tenham revelado durante as entrevistas considerarem, tal como aponta o PPP, a continuidade das experiências um objetivo importante, não há na prática a sistematização de ações que viabilizem tal continuidade.

Por fim, as professoras percebem a importância dos momentos de formação, mas questionam sua eficácia, bem como a ausência de discussões mais profundas sobre o quanto as crianças poderiam envolver-se em experiências contínuas durante as dez horas que permanecem na unidade.

Há que se pensar, portanto, na mobilização de uma série de mecanismos que garantam no contexto dos Centros de Educação Infantil, tempos para o coletivo, para a partilha de experiências e práticas. Tempos para uma formação que garanta discussões efetivas a respeito do que é vivido, para se pensar ações conjuntas que levem todas as experiências vivenciadas pelas crianças a se configurarem como experiências expressivas de aprendizagem. 


\section{CONSIDERAÇÕES FINAIS}

A educação infantil, particularmente a etapa destinada ao período de 0 a 3 anos, busca atualmente legitimar-se como um expressivo campo de atuação e pesquisa, o que tem implicado o enfrentamento de muitos desafios e o surgimento de muitas possibilidades de práticas inovadoras ainda por serem exploradas.

O processo de integração do atendimento das crianças de 0 a 3 anos ao sistema educacional brasileiro conferiu às creches um novo estatuto que as aproxima dos protocolos vigentes na pré-escola e até mesmo no ensino fundamental, o que por vezes levou à negligência de suas peculiaridades. Ora, o cuidado e a educação de bebês e crianças muito pequenas exigem condições estruturais e organizativas muito particulares. Como sustenta Barbosa (2010):

Se, nos últimos anos, as vagas foram quantitativamente ampliadas ainda não é possível afirmar que uma pedagogia específica para as crianças pequenas tenha sido efetivada. Em grande parte das instituições, as singularidades das crianças de 0 a 3 anos, especialmente os bebês, ficaram subsumidas às compreensões sobre 0 desenvolvimento e a educação das crianças mais velhas (BARBOSA, 2010, p. 2).

Nos debates mais recentes sobre a educação das crianças de 0 a 3 anos, merecem relevo as questões relativas ao currículo voltado para essa etapa. Há um esforço de profissionais do campo, pesquisadores e práticos, em conferir uma identidade própria às creches, constituindo uma reflexão em torno de propostas curriculares pautadas em tempos, espaços e relações condizentes com a natureza de trabalho para essa faixa etária. Como diz Barbosa (2010), quando pensamos nas crianças bem pequenas, surgem muitas dúvidas sobre como propor o currículo, contudo há algumas certezas também. Uma delas é que esse currículo não será proposto por meio de aulas e exposições verbais, mas a partir da criação de uma vida cotidiana com práticas sociais que possibilitem alargar horizontes, ampliar vivências em linguagens, para que os bebês e as crianças maiores experimentem seus saberes.

A pesquisa que ora se conclui inseriu-se nesse cenário de discussões sobre o currículo, adotando nesse contexto a perspectiva da Pedagogia-em-Participação, que se assenta sobretudo nos conceitos deweyanos, destacando o lugar das aprendizagens experienciais no centro de uma pedagogia da infância. Nesses termos, a aprendizagem 
experiencial integra-se às "cem linguagens da criança" (OLIVEIRA-FORMOSINHO, 2011).

Partindo desse ponto de vista, o presente estudo propôs compreender como se desenvolvem as práticas educativas de duas duplas de professoras, pensadas para o mesmo agrupamento de crianças. Esse objetivo implicou um processo de imersão em um Centro de Educação Infantil vinculado à rede municipal de São Paulo, ao longo do qual fora produzidos dados advindos de três fontes: documental; depoimentos das professoras e gestoras obtidos por entrevistas; e registros decorrentes de sessões de observação da rotina da turma de crianças em foco. Na confluência dessas fontes, buscou-se elucidar em que medida os momentos de formação permitiam às quatro professoras (as duplas da manhã e da tarde) efetuar planejamentos conjuntos e trocas de experiências sobre seus trabalhos diários com as crianças; e como os seus planejamentos se traduziam nas práticas cotidianas e, por esse viés, que natureza de experiências de aprendizagens eram propiciadas às crianças.

Partiu-se da compreensão de que o contexto de cada CEI é único, por abrigar concepções, valores e propostas próprias dos sujeitos que ali se reúnem, constituindo a história própria da unidade. Com isso se quer dizer que cada instituição, ao fazer suas escolhas em termos de utilização de tempos, espaços, experiências de aprendizagens, revelam suas concepções e, por conseguinte, o sentido da proposta curricular adotada em seu projeto político pedagógico.

A investigação documental permite afirmar que o CEI estudado revela em seu PPP uma orientação curricular alinhada aos documentos oficiais. Essa orientação está pautada em concepções progressistas e valoriza, sobretudo, as experiências infantis, bem como a constante ampliação dessas experiências. Sustenta-se em bases democráticas e nos conceitos de acesso aos saberes e participação e tanto das famílias como das crianças e demais segmentos que compõem a instituição. Essas noções são coerentes também com os princípios da Pedagogia-em-Participação. Conforme esses preceitos, o Centro de Educação Infantil deve ser organizado para que a democracia seja simultaneamente um fim e um meio, isto é, presente tanto nas grandes finalidades educativas como no âmbito do cotidiano participativo (OLIVEIRA-FORMOSINHO, 2011). 
Embora o PPP da unidade contemple princípios de democracia e participação, o que se revela no plano e nas práticas cotidianas das professoras são ações que não conseguem traduzir plenamente esses princípios. Parece haver, por parte da instituição, o desejo de realizar um trabalho que garanta a participação, contudo os meios para alcançar tal fim não são vislumbrados. É o que se nota nos processos formativos que ocorrem no âmbito do CEI, os quais deveriam suscitar discussões e reflexões constantes sobre as concepções e os planos de ação delineados pela equipe em seu contexto de trabalho, mas não atingem seu objetivo. (PINAZZA; NEIRA, 2012).

Como postulam Pinazza e Neira (2012, p. 13),

Num país como o Brasil, em que não há uma tradição de formação inicial específica de profissionais para a educação das crianças pequenas, distanciar a formação da situação de trabalho é preterir o cenário essencial em que se revelam identidades e formas de pensar e proceder.

Embora haja o reconhecimento da importância da formação em contexto para a elevação da qualidade das práticas educativas, no CEI em que se deu a pesquisa, a exemplo do que ocorre em outros CEIs municipais, as condições estruturais e organizativas não asseguram nem um período de formação mais ampliado, nem momentos em que toda a equipe, especialmente as professoras, possam reunir-se e elaborar reflexões coletivas e trocar experiências. Esses dados, do ponto de vista de Zeichner (1993), contradizem a condição de coletividade necessária à instalação de uma comunidade de aprendizagens.

Além do mais, nem mesmo durante a formação em PEA há espaços para que as professoras troquem e compartilhem suas experiências, sendo a única maneira de comunicação entre as duplas o "caderno de comunicação" em que se registra em termos gerais como foi cada período. $O$ instrumento de que as duplas se valem para comunicação e, de alguma forma, para planejamento são: caderno de comunicação, semanário ou diário, os quais lhes permite saber o que foi realizado em cada período. No entanto, tais instrumentos não dão conta da amplitude do processo, tampouco implicam uma construção coletiva do planejamento, o que acarreta a fragmentação e descontinuidade das práticas.

Constata-se a preocupação e o comprometimento das professoras com o grupo de crianças e a intenção de lhes oferecer experiências importantes. No entanto, esse desejo se choca com uma série de fatores que constituem a história das creches 
brasileiras (ROSEMBERG, 1984; HADDAD, 1991; CAMPOS, ROSEMBERG, FERREIRA, 1995; KUHLMAMM JR.,1998). Dentre esses fatores, encontram-se as adversas condições da formação inicial e contínua dos profissionais que atuam diretamente nessas instituições, que pouco avançou, apesar do reconhecimento frequentemente enunciado à relevante função educativa das instituições de educação infantil e, particularmente, daquelas destinadas a cuidar e educar bebês e crianças pequenas. Como ponderam Gatti e Barretto (2001), para que haja uma mudança capaz de produzir impactos na prática pedagógica, são necessárias ações que caminhem para uma transformação cultural no âmbito da formação docente; do contrário, essas mudanças podem ficar somente no âmbito legal.

Uma vez que não há em âmbito nacional uma política de formação específica para a docência na infância, a formação contínua dentro da instituição educacional necessita de tempos e espaços mais amplos, que proporcionem de fato estudos e reflexões profundos voltadas à especificidade dos fazeres docentes no contexto do Centro de Educação Infantil (GATTI e BARRETTO, 2001; PINAZZA, 2004).

É possível que, em decorrência da ausência de momentos coletivos de formação e planejamento conjunto entre as duplas de professoras, as crianças vivenciem momentos da rotina descolados e sem continuidade. Nesse aspecto, no que se refere aos planejamentos das professoras e às práticas educativas desenvolvidas por elas, a investigação trouxe evidências de que não há um sentido de continuidade e de fluidez entre as realizações da manhã e da tarde, o que pode resulta em experiências com menor potencial de engendrar outras experiências de aprendizagens mais ampliadas, tal como anunciada por Dewey.

Constatou-se que nas condições postas no CEI, não há possibilidade de o planejamento se articular, o que afeta e compromete a continuidade das experiências vividas pelas crianças. Isso não ocorre dentro do mesmo período, tampouco entre os períodos, de maneira que não condições de preparar experiências educativas articuladas em que as crianças possam mobilizar capacidades e produzir sentidos que possam ser recuperados em outras situações futuras (AUGUSTO, 2013; PINAZZA, 2014).

Uma experiência expressiva de aprendizagem deve não só engendrar outras experiências, desencadeando constantes pesquisas, como também ampliar a rede de significações e o conhecimento das crianças. Para que isso ocorra, devem estar asseguradas as condições de interação e continuidade. Na perspectiva da interação, deve-se considerar que a experiência não se processa no vácuo, ela surge num contexto 
e é mediada pela cultura dos sujeitos envolvidos. A experiência surge da relação que a criança estabelece com seu meio, com os sujeitos e objetos ao seu redor. Portanto, é na interação com a cultura que meninos e meninas iniciam a jornada curiosa que os direciona à pesquisa e à descoberta de novas aprendizagens. Quanto mais aproximadas são as experiências do contexto social e cultural das crianças, mais expressiva elas se tornam, o que implica dizer que a criança não aprende com a experiência, e sim na experiência (DEWEY, 1980; PINAZZA, 2007). Outra condição para que a experiência seja realmente expressiva é o sentido de continuidade. Garantir no planejamento a continuidade experiencial significa assegurar às experiências a potência para se ampliarem e transformarem-se mediante processos de exploração, investigação e sistematização e, por conseguinte, de construção de conhecimentos pela criança.

A pesquisa revelou a preocupação das professoras em tornar o dia menos cansativo às crianças, o que se revelava no seu esforço em oferecer possibilidades de circunstâncias contextuais e atividades diferenciadas, nos dois períodos. No entanto, esse raciocínio revela-se equivocado, posto que nos dois períodos as crianças vivem experiências descoladas umas das outras. Elas não experimentam o exercício de continuidade daquilo que estão constituindo de um momento para o outro do seu dia. Como escreve Augusto (2013), análises de percursos criativos de crianças mostram o contrário: a novidade não está na atividade aplicada pela professora, mas sim nas novas descobertas resultantes da atividade da própria criança e do sentido que ela constrói para o que está realizando.

Do exposto, conclui-se que experiências pontuais e descontínuas são frágeis, com pouca substância e, portanto, não se constituem em experiências expressivas de aprendizagem, reduzindo-se ao cumprimento de atividades postas no planejamento.

O estudo provoca uma reflexão acerca da maneira como se constituem as propostas curriculares no contexto do CEI. Vale salientar que a composição de uma proposta curricular demanda da equipe um exercício contínuo de reflexão coletiva que elabore práticas concretas a partir dos planejamentos idealizados pelas profissionais. $\mathrm{O}$ CEI estudado e os demais CEIs municipais vivem uma condição singular: devem compor, para um mesmo agrupamento, um planejamento pretensamente partilhado pelas professoras de ambos os períodos, manhã e tarde, envolvendo quatro profissionais. Portanto, no caso dos CEIs é mais premente a necessidade de se proverem processos 
formativos que coloquem em questão o cotidiano das práticas endereçadas às mesmas crianças em dois períodos do seu dia-a-dia no CEI.

Esse estudo suscita, por meio da análise da condição inerente ao CEI estudado, a necessidade de outras pesquisas que ampliem o conhecimento a respeito dos processos organizativos de instituições como essa e que desvelem crescentemente as propostas curriculares tal como elas são vividas pelos atores diretamente envolvidos, adultos e crianças. Essas investigações deverão inspirar os legisladores na formulação de enunciados das políticas públicas voltadas à educação infantil e à formação contínua em serviço para aqueles que atuam nessa área. É preciso assegurar legalmente condições estruturais e organizativas adequadas aos CEIs, de tal modo que tempos e espaços de formação sejam mais amplos e propícios aos processos de reflexão coletiva sobre as práticas idealizadas e concretizadas e, desse modo, efetivem uma pedagogia da infância de boa qualidade. 


\section{REFERÊNCIAS}

ABUCHAIM, B. O. Currículo, planejamento pedagógico e cotidiano na pré-escola: do prescrito-planejado ao experienciado-vivido. Tese de Doutorado. PUC- São Paulo, 2012.

ANGOTTI, M. Maria Montessori: uma mulher que ousou viver transgressões. In: OLIVEIRA-FORMOSINHO, J.; KISHIMOTO, T. M.; PINAZZA, M. A. (Orgs.). Pedagogia(s) da Infância: dialogando com o passado: construindo o futuro. Porto Alegre: Artmed, 2007.

ARAÚJO, J.M; ARAÚJO, F.A. Maria Montessori: Infância Educação e Paz. In: OLIVEIRA-FORMOSINHO, J.; KISHIMOTO, T. M.; PINAZZA, M. A. (Orgs.) Pedagogia(s) da Infância: dialogando com o passado: construindo o futuro. Porto Alegre: Artmed, 2007.

Célestin Freinet: trabalho, cooperação e aprendizagem. In: OLIVEIRAFORMOSINHO, J.; KISHIMOTO, T. M.; PINAZZA, M. A. (Orgs.) Pedagogia(s) da Infância: dialogando com o passado: construindo o futuro. Porto Alegre: Artmed, 2007.

ARRIBAS, L. T. Educação Infantil: desenvolvimento, currículo e organização escolar. $5^{\circ}$ Ed. Porto Alegre: Artmed, 2004.

AUGUSTO, S. O. A Experiência de Aprender na Educação Infantil. In. Novas Diretrizes Para a educação Infantil. Ano XIII, boletim 9. Salto para o Futuro: Brasília, 2013.

BARBOSA, M. C. Os resultados da avaliação de propostas curriculares para a educação infantil dos municípios brasileiros. In: SEMINÁRIO NACIONAL: CURRÍCULO EM MOVIMENTO - PERSPECTIVAS ATUAIS, 1., 2010, Belo Horizonte. Anais...Belo Horizonte, 2010.

BARBOSA, M. C \& RICHTER , S. R. S. , Direito das crianças como estratégia para a educação das crianças pequenas . Trabalho Apresentado na $34^{\mathrm{a}}$ reunião anual da ANPED. Natal, 2011. Disponível em : http://34reuniao.anped.org.br

BARRETO, A. M. R. F. Educação Infantil no Brasil: Desafios colocados. In: Cadernos CEDES, $n^{\circ}$ 37. Grandes Políticas para os Pequenos. Papirus: Campinas, 1995.

BOGDAN, R. C.; BIKLEN, S. K. Investigação qualitativa em educação: uma introdução à teoria e aos métodos. Porto: Porto Editora, 1999.

BRASIL. Conselho Nacional de Educação. Câmara de Educação Básica. Parecer CNE/CEB no 20/2009. Revisão das Diretrizes Curriculares Nacionais para a Educação Infantil. Brasília: CNE/CEB, 2009a. 
Constituição da República Federativa do Brasil. Brasília: Imprensa Oficial, 1988. Disponível em: <http://www.planalto.gov.br/ccivil_03/constituicao/constituicao.htm>. Acesso em: 10 abr. 2013.

- Diretrizes Curriculares Nacionais para Educação Infantil. Brasília: MEC/SEB/COEDI, 2009c.

Lei $n^{0}$ 9.394, de 20 de dezembro de 1996. Lei de Diretrizes e Bases da Educação Nacional. Brasília: Imprensa Oficial, 1996.

- Política Nacional de Educação Infantil: pelo direito das crianças de 0 a 6 anos.Brasília: MEC/SEF/COEDI, 2006.

Referencial Curricular Nacional para a Educação Infantil. Brasília: MEC/SEF, 1998. v. 1 e 2.

Critérios para um atendimento em creches que respeite os direitos fundamentais das crianças. Brasília: MEC/SEB/COEDI, 2009.

CAMPOS, M. M. A constituinte e a educação da criança de 0 a 6 anos. In: SIMPÓSIO CEB SOBRE PRÉ-ESCOLA, 4., 1986, Goiânia. Anais... Goiânia, 1986.

$117-127,1999$.

; A mulher, a criança e seus direitos. Cadernos de Pesquisa n.106, pp.

CAMPOS, M. M; ROSEMBERG, F.; FERREIRA, I. M. Creches e Pré-escolas no Brasil. 2. ed. São Paulo: Cortez, 1995.

CERISARA, A. B. A produção acadêmica na área da educação infantil com base na análise dos pareceres sobre o Referencial Curricular Nacional para a Educação Infantil: primeiras aproximações. In: FARIA, A. L. G. de; PALHARES, M. S. (Org.). Educação infantil pós-LDB: rumos e desafios. 6. ed. Campinas: Autores Associados, 2007.

DEWEY, J. Experiência e natureza. IN. Experiência e natureza; Lógica: a teoria da Investigação; A arte como experiência; Vida e Educação; teoria da Vida Moral;

Coleção : Os Pensadores.Traduções: Murilo Otávio Paes Leme; Anísio S. Teixeira;

Leônidas Gontijo de Carvalho/ São Paulo: Abril Cultural, 1980

Nacional: 1933.

Como Pensamos: Série III. Vol.II São Paulo: Companhia Editorial

DIDONET, V. A LDB e a política de educação infantil. In: MACHADO, M. L. de A. (Org). Educação infantil em tempos de mudança. São Paulo: FCC/DPE, p. 13-24, 2000 .

EDWARDS, C.; GANDINI, L.; FORMAN, G. As cem linguagens da criança: abordagem de Reggio Emilia na educação da primeira infância. Porto Alegre: ArtMed, 1999. 
ELIAS, M. D. C.; SANCHES, E. C. Freinet e a pedagogia- uma velha idéia muito atual. In. OLIVEIRA-FORMOSINHO, J.; KISHIMOTO, T. M.; PINAZZA, M. A. (Orgs.) Pedagogia(s) da Infância: dialogando com o passado: construindo o futuro. Porto Alegre: Artmed, 2007.

FARIA, A. L. G. de , Políticas de regulação, pesquisa e pedagogia na educação infantil, primeira etapa da educação básica. Educação e Sociedade, Campinas, v. 26, n. 92, out. p.1013- 1038. 2005.

Loris Malaguzzi e os direitos das crianças pequenas. In. OLIVEIRAFORMOSINHO, J.; KISHIMOTO, T. M.; PINAZZA, M. A. (Orgs.). Pedagogia(s) da Infância: dialogando com o passado: construindo o futuro. Porto Alegre: Artmed, 2007.

FESTA, M. A(des) construção de um espaço e (re) construção de uma prática educativa: a jornada de uma professora de Educação Infantil num espaço reorganizado. Dissertação de Mestrado. Faculdade de Educação da Universidade de São Paulo, 2008.

FREIRE, P. Pedagogia do oprimido. Rio de Janeiro, RJ: Paz e Terra, 1970.

GARCIA, R. L.; MOREIRA, A. F. Começando uma conversa sobre currículo. In: ; _ (Org.). Currículo na contemporaneidade: incertezas e desafios. São

Paulo: Cortez, 2003.

GIROUX, H. Teoria crítica e resistência em educação. Petrópolis: Vozes, 1986

GOBBI, M. A. O tempo perguntou ao tempo... Tempos e espaços para brincar na educação infantil. In: TV-ESCOLA. Brinquedos e brincadeiras na creche e na préescola. Brasília, ano XXIII, Boletim, 12 jun. 2013. (Coleção Salto para o Futuro). Disponível em: <http://tvescola.mec.gov.br>.Acesso em: 10 nov. 2013.

GOBBI, M. A. O tempo perguntou ao tempo... Tempos e espaços para brincar na educação infantil. In: TV-ESCOLA. Brinquedos e brincadeiras na creche e na préescola. Brasília, ano XXIII, Boletim, 12 jun. 2013. (Coleção Salto para o Futuro). Disponível em: <http://tvescola.mec.gov.br>. Acesso em: 10 nov. 2013

GOMÈZ, G. R.; FLORES, J.; JIMÈNEZ, E. Metodologia de la investigacion cualitativa. Málaga: Ediciones Aljibe, 1996.

GOODSON, I. F. Currículo: teoria e história. Vozes: Petrópolis, 1995.

Currículo, narrativa e o futuro social. Revista Brasileira de Educação, Rio de Janeiro, v. 12, n. 35, p. 240-252, maio/ago. 2007.

HADDAD, L. A creche em busca de identidade. São Paulo: Loyola, 1991.

KISHIMOTO, T. M. A pré-escola em São Paulo (1887-1940). São Paulo: Edições Loyola, 1988. 
KISHIMOTO, T. M.; PINAZZA, M. A. Froebel: Uma Pedagogia do brincar para a Infância. In. OLIVEIRA-FORMOSINHO, J.; KISHIMOTO, T. M.; PINAZZA, M. A. (Orgs.). Pedagogia(s) da Infância: dialogando com o passado: construindo o futuro. Porto Alegre: Artmed, 2007.

KISHIMOTO, T. M. Brinquedos e brincadeiras nas creches e pré-escolas. In: TVESCOLA. Brinquedos e brincadeiras na creche e na pré-escola. Brasília, ano XXIII, Boletim, 12 jun. 2013. (Coleção Salto para o Futuro). Disponível em: <http://tvescola.mec.gov.br>.Acesso em: 10 nov. 2013.

KUHLMANN JR. M. Educação infantil e currículo. In: FARIA, A. L. G. de; PALHARES, M. S. (Org.). Educação infantil pós-LDB: rumos e desafios. 6. ed. Campinas: Autores Associados, 2007.

Infância e Educação Infantil: uma abordagem histórica. Porto Alegre: Mediação, 1998.

LANKSHEAR, C.; KNOBEL, M. Pesquisa pedagógica: do projeto à implementação. Porto Alegre: Artmed, 2008.

LIMA, E. S. et al. Trabalhando com pajens. Cadernos de Pesquisa, São Paulo, n. 49, p. 71-86, maio 1984.

LINO, D. O Modelo Pedagógico de Reggio Emilia. In: Modelos Curriculares para a Educação de Infância. Construindo uma práxis da participação. $3^{\circ}$ Ed. Porto: Porto Editora, 2007.

MELLO, S. A. Um mergulho no letramento a partir da educação infantil. In: SÃO PAULO (Município). Secretaria Municipal de Educação. Caderno Temático de Formação II Educação Infantil. Construindo a Pedagogia da Infância no município de São Paulo. São Paulo: SME, 2004. Disponível em: <http://portal.iphan.gov.br>. Acesso em: 10 nov. 2013.

NASCIMENTO, M. L. de. Contextos de educação da infância: parceria entre famílias e as instituições de educação infantil. In: SÃO PAULO (Município). Secretaria Municipal de Educação. Caderno Temático de Formação II Educação Infantil. Construindo a Pedagogia da Infância no município de São Paulo. São Paulo: SME, 2004. Disponível em: 〈http://portal.iphan.gov.br>. Acesso em: 10 nov. 2013.

NIZA, S. O Modelo Curricular da Educação Pré-Escolar da Escola Moderna Portuguesa. In: Modelos Curriculares para a Educação de Infância. Construindo uma práxis da participação. $3^{\circ}$ Ed. Porto: Porto Editora, 2007.

OLIVEIRA. Z. M. R. Educação infantil: fundamentos e métodos. São Paulo: Cortez, 2005.

OLIVEIRA -FORMOSINHO, J. O desenvolvimento profissional das educadoras de infância: Um estudo de caso. Tese de Doutorado. Universidade do Minho: Instituto de Estudos da Criança, 1998.

Pedagogia(s) da Infância : reconstruindo uma práxis da participação. In . OLIVEIRA-FORMOSINHO, J.; KISHIMOTO, T. M.; PINAZZA, M. A. (Orgs.) 
Pedagogia(s) da Infância: dialogando com o passado: construindo o futuro. Porto Alegre: Artmed, 2007.

Pedagogia(s) da Infância : reconstruindo uma práxis da participação. In: Modelos Curriculares para a Educação de Infância. Construindo uma práxis da participação. $3^{\circ}$ Ed. Porto: Porto Editora, 2007.

O Espaço e o tempo na Pedagogia-em-Participação. In: O espaço e o Tempo na Pedagogia-em-Participação. OLIVEIRA-FORMOSINHO, J. (Org.) Coleção Infância. Porto: Porto Editora, 2011.

Pedagogia-em-Participação: a perspectiva da Associação Criança. In: O espaço e o Tempo na Pedagogia-em-Participação. OLIVEIRA-FORMOSINHO, J. (Org.) Coleção Infância. Porto: Porto Editora, 2011.

A contextualização do Modelo Curricular High-Scope no Âmbito do Projeto Infância. In: Modelos Curriculares para a Educação de Infância. Construindo uma práxis da participação. $3^{\circ}$ Ed. Porto: Porto Editora, 2007.

A profissionalidade específica da educação da infância e os estilos da interação adulto/criança: infância e educação - investigação e práticas. Revista do GEDEI, Rio de Janeiro, p. 153-173, 2000.

KISHIMOTO, T.; PINAZZA, M. A. (Org.). Pedagogia da infância: dialogando com o passado, construindo o futuro. Porto Alegre: Artmed, 2007.

PINAZZA, M. A. A educação infantil e suas especificidades. In: GERALDI, C. M. G; RIOLFI, C. R.; GARCIA, M. F. (Org.). Escola viva: elementos para a construção de uma educação de qualidade social. Campinas, SP: Mercado das Letras, 2004. p. 371385.

John Dewey: inspirações para uma pedagogia da Infância. In:

OLIVEIRA-FORMOSINHO, J. KISHIMOTO, T. M.; PINAZZA, M. A. (Orgs). Pedagogia(s) da Infância: dialogando com o passado: construindo o futuro. Porto Alegre: Artmed, 2007.

Desenvolvimento profissional em contexto: estudo de condições de formação e mudança. In: KISHIMOTO, T. M.; OLIVEIRA-FORMOSINHO (Org.). Em busca da pedagogia da infância: pertencer e participar. Porto Alegre: Penso, 2013a.

Formação profissional e práticas de supervisão em contexto. In: CARVALHO, A. M. P. de (Org.). Formação de professores: múltiplos enfoques. São Paulo: Sarandi, 2013b.p. 225-250.

- Formação de Profissionais da Educação Infantil em Contextos Integrados. Informes de uma investigação-ação. Tese de Livre Docência. Universidade de São Paulo. São Paulo, 2014.

PINAZZA, M. A.; NEIRA, M. (Org.). Formação de profissionais da educação infantil: desafio conjunto de investir na produção de saberes. São Paulo: Xamã, 2012 
Formação de Profissionais de Educação Infantil em Contextos Integrados. Informes de uma Investigação-ação. Tese de Livre Docência, 2014. Disponível em: 〈www.teses.usp.br/teses/disponiveis/livredocencia>. Acesso em : 23/12/2014.

RICHTER, S. R. S; BARBOSA, M. C. Os bebês interrogam o currículo: as múltiplas linguagens na creche. Educação, Santa Maria, v. 35, n. 1, p. 85-96, jan./abr. 2010. Disponível em: 〈http://www.ufsm.br/revistaeducacao〉. Acesso em: 10 nov. 2013.

ROSEMBERG, F. Creche. Cadernos de Pesquisa da Fundação Carlos Chagas, São Paulo, 1984.

O movimento de mulheres e a abertura política no Brasil: o caso da creche. Cadernos de Pesquisa, São Paulo, n. 51, p. 73-79, 1984.

ROSEMBERG, F.; CAMPOS, M. M.; HADDAD, L. A rede de creches no município de São Paulo. São Paulo: Fundação Carlos Chagas; Departamento de Pesquisas Educacionais, 1991.

SANCHES , E. S. Creche: realidade e ambigüidades . São Paulo: Vozes , 2003.

SANTOS, Y. G dos. A implementação dos órgãos governamentais de gênero no Brasil e o papel do movimento feminista: o caso do Conselho Estadual da Condição Feminina de São Paulo. Cadernos Pagu n.27, pp. 401-426, 2006.

SÃO PAULO (Município). Decreto no 40.268, de 31 de janeiro de 2001. Dispõe sobre a efetivação de diretrizes de integração das creches ao Sistema Municipal de Ensino, e dá outras providências. São Paulo: Imprensa Oficial, 2001a.Disponível em: <http://www3.prefeitura.sp.gov.br/cadlem/secretarias/negocios_juridicos/cadlem/integr a.asp?alt=01022001D\%20402680000>. Acesso em: 10 nov. 2013.

Decreto $n^{0}$ 41.558, de 28 de dezembro de 2001. Transfere os Centros de Educação Infantil da rede direta da Secretaria Municipal de Assistência Social - SAS para a Secretaria Municipal de Educação - SME, e dá outras providências. São Paulo: Imprensa Oficial, 2001b. Disponível em:

<http://portalsme.prefeitura.sp.gov.br/Projetos/sitemerenda/Anonimo/legislacao/decreto s/decreto_41.588.aspx>. Acesso em: 10 nov. 2013.

(Município). Decreto $n^{\circ} \mathbf{4 4 . 8 4 6 ,}$ de 14 de junho de 2004. Define as atribuições próprias do cargo de Professor de Desenvolvimento Infantil, nos termos do artigo 21 da Lei $\mathrm{n}^{\circ}$ 13.574, de 12 de maio de 2003. São Paulo: Imprensa Oficial, 2004a.Disponível em: <http://www3.prefeitura.sp.gov.br/cadlem/secretarias/negocios_juridicos/cadlem/integr a.asp?alt=15062004D\%20448460000>. Acesso em: 10 dez. 2013. 
Lei $n^{\circ} 13.574$ de 12 de maio de 2003. Dispõe sobre a transformação e inclusão no quadro do magistério municipal, do quadro dos profissionais de educação dos cargos de auxiliar de desenvolvimento infantil, pedagogo e diretor de equipamento social, e dá outras providências. São Paulo: Imprensa Oficial, 2003. Disponível em: <http://cm-sao-paulo.jusbrasil.com.br/legislacao/811483/lei-13574-03\#art-10>. Acesso em: 10 nov. 2013.

Secretaria Municipal de Educação. Caderno Temático de Formação II Educação Infantil. Construindo a Pedagogia da Infância no município de São Paulo. São Paulo: SME, 2004b. Disponível em: 〈http://portal.iphan.gov.br〉. Acesso em: 10 nov. 2013.

Orientação Normativa $\mathbf{n}^{\mathbf{0}}$ 01/2004. Construindo um Regimento da Infância. São Paulo: SME, 2004c. Disponível em: 〈www.prefeitura.sp.gov.br〉. Acesso em: 10 nov. 2013.

- Diretoria de Orientação Técnica. Cadernos da Rede: Narrativas Infantis no Jogo de Faz de Conta. São Paulo: DOT-EI, 2010. Disponível em: <http://portalsme.prefeitura.sp.gov.br/Projetos/BibliPed/Anonimo/Educa\%C3\%A7\%C3 $\%$ A3o\%20Infantil.aspx?MenuID=18\&MenuIDAberto=12>. Acesso em: $10 \mathrm{dez} .2013$.

Divisão Técnica de Educação Infantil. Tempos e espaços para a infância e suas linguagens nos CEIs, creche e EMEIs da cidade de São Paulo. São Paulo: SME, 2006a. Disponível em: 〈http://portalsme.prefeitura.sp.gov.br〉. Acesso em: 10 nov. 2013.

Divisão Técnica de Educação Infantil. Orientações Curriculares: expectativas de aprendizagem e orientações didáticas para a educação infantil. São Paulo: SME, 2007. Disponível em: 〈http://portalsme.prefeitura.sp.gov.br〉. Acesso em: 10 nov. 2013.

SÃO PAULO (Município).Secretaria Municipal de Educação.Homepage. São Paulo: SME, 20013. Disponível em: <http://portalsme.prefeitura.sp.gov.br/Projetos/sitemerenda/Anonimo/legislacao/portaria s/portaria_938.aspx>. Acesso em: 10 dez. 2013.

Portaria SME no 938, de 14 de fevereiro de 2006. Institui o Programa "A Rede em rede: a Formação Continuada na Educação Infantil" e dá outras providências. São Paulo: SME, 2006b. Disponível em: $<$ http://portalsme.prefeitura.sp.gov.br/Projetos/sitemerenda/Anonimo/legislacao/portaria s/portaria_938.aspx>. Acesso em: 10 maio 2013.

Portaria SME n⿳ 1.566, de 18 de março de 2008. Dispõe sobre Projetos Especiais de Ação - PEAs e dá outras providências. São Paulo: SME, 2008a.Disponível em:

$<\underline{\text { http://portalsme.prefeitura.sp.gov.br/Documentos/BibliPed/TextosLegais/Portarias_S }}$ ME_2009.pdf $>$. Acesso em: 5 maio 2013.

Portaria SME $n^{0}$ 4.618, de 18 de novembro de 2008. Dispõe sobre a organização das unidades de educação infantil, de ensino fundamental, de ensino 
fundamental e médio e dos Centros Educacionais Unificados da rede municipal de ensino para o ano de 2009, e dá outras providências. São Paulo: SME, 2008b. Disponível em:<http://www.sinpeem.com.br/lermais_materias.php?cd_materias=2198\#.UqeHW9J DuHs>. Acesso em: 10 maio 2013.

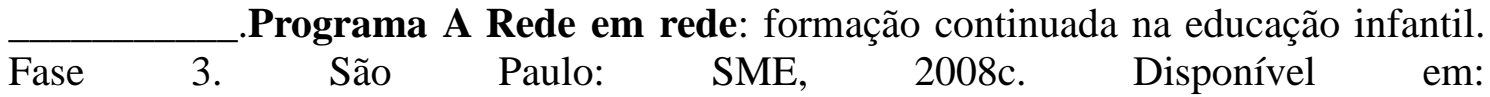
$<$ http://portalsme.prefeitura.sp.gov.br/Projetos/ei/AnonimoSistema/BannerTexto.aspx? MenuBannerID=28>. Acesso em: 10 dez. 2013.

Programa A Rede em rede: formação continuada na educação infantil. Fase 4. São Paulo: SME, 2009. Disponível em: <http://portalsme.prefeitura.sp.gov.br/Projetos/ei/AnonimoSistema/BannerTexto.aspx? MenuBannerID=28>. Acesso em: 10 dez. 2013. SEBES, 1989.

Secretaria Municipal do Bem-Estar Social. Política de creche. São Paulo:

Orientação Normativa $n^{\circ} 01$ de 02 de dezembro de 2013. Avaliação na Educação Infantil. Aprimorando os Olhares.SME - São Paulo, 2013. Disponível em: http://www.portalsme.prefeitura.sp.gov.br/Documentos/BibliPed/TextosLegais/coletane a_2014_Orientacoes_Normativas_Outras\%20Secretarias_Comunicados_SME.pdf Acesso: 03 agosto/2013.

SCHEFFLER, I. A linguagem da educação. São Paulo: Saraiva/EDUSP, 1974.

SILVA, T. T da. Documentos de identidade: uma introdução às teorias do currículo. Petrópolis: Vozes, 1999.

STENHOUSE, L. Investigación y desarrollo del curriculum. Madri: Morata, 1991.

YIN, R. K. Estudo de caso: planejamento e métodos. 3. ed. Porto Alegre: Bookman, 2005.

ZEICHNER, K. M. A formação reflexiva de professores: ideias e práticas. Lisboa: Educa, 1993 


\section{APÊNDICES}

\section{APÊNDICE A - Roteiro de entrevista individual com as Professoras}

\section{Identificação:}

Identifique-se como você quiser, falando minimamente: seu nome, idade, nível de formação e experiências profissionais.

\section{Sobre o dia a dia profissional:}

Relate seu dia a dia no CEI, explicitando como ocorrem as comunicações entre as docentes e a gestão (diretora e coordenadora pedagógica) e entre as quatro docentes do seu agrupamento de crianças.

\section{Sobre o processo de formação dentro do CEI:}

Relate como você vê os encontros de formação dentro do CEI, dizendo se eles têm ou não impacto sobre suas práticas e se eles permitem a troca de experiências de práticas entre as professoras do CEI. Também pode dizer se você teria alguma sugestão para mudar algo nesse processo de formação.

\section{Sobre a prática pedagógica:}

1) O que pensa sobre a organização dos tempos e espaços nesta instituição?

2) Como é pensado o projeto político-pedagógico da unidade?

3) Em que medida o planejamento do trabalho com o agrupamento relaciona-se ao projeto da unidade?

4) Em sua opinião, quais os momentos da rotina diária do CEI que você julga mais marcantes? Por quê?

5) Como esses momentos aparecem em seu planejamento?

6) Como você concebe a rotina em seu planejamento? Em que elementos você se apoia?

7) Em que você pensa ao planejar seu trabalho?

8) Em que medida você consegue perceber a participação da criança e das famílias em seu processo de planejar?

9) Como o seu planejamento se encontra com os planejamentos de suas colegas do mesmo agrupamento? 
10) Como vocês se organizam para planejar as ações para o mesmo agrupamento? Existe um planejamento comum para o agrupamento?

11) Em que medida você e sua parceira de trabalho conseguem concretizar o que planejaram para o período? Que dificuldades você encontra no desenvolvimento daquilo que planejaram?

12) Como são tratados os imprevistos em seu planejamento?

13) Como as professoras dos dois períodos trocam informações?

14) Como trocam experiências de práticas? 


\title{
APÊNDICE B - Relato escrito sobre o cotidiano profissional das Professoras envolvidas na pesquisa
}

\author{
As seguintes questões foram lançadas: \\ Como é o seu cotidiano profissional? Como você vive esse cotidiano?
}

\section{PROFESSORA O}

Meu nome é O, tenho 30 anos e 10 na educação infantil.

Gosto muito da educação infantil. Aqui aprendo a cada dia muitas coisas novas. Há sempre um desafio. Iniciei como monitora em um colégio particular importante em Osasco (Leonardo da Vince - Anglo). Lá aprendi muito sobre o cotidiano escolar, a interação com as crianças e professores. Também tive a oportunidade de conhecer e aprender inúmeras coisas sobre a organização escolar, como: calendário, bilhetes, organização de eventos, atendimentos as famílias etc. Também acompanhei meu primeiro grupo de alunos no "reforço escolar", no contraturno. Nessa época, ainda estava encerrando meu curso de pedagogia. Logo que encerrei o curso de pedagogia, prestei o meu $1^{\circ}$ concurso, em 2004, para o cargo que ocupo agora. Tive a oportunidade de prestar outros concursos nos quais consegui passar: Estado de SP, PM Taboão da Serra e PM de Osasco. A princípio, devido à experiência com o fundamental no colégio particular, achava que seguiria no fundamental. Porém, como estava em processo de crescimento pessoal, trabalhava concomitantemente no FUND-I e aqui no CEI. Assim, consegui adquirir meu carro e meu apartamento. Porém, quando minha filha nasceu, tomei a decisão de deixar um emprego para acompanhar seu crescimento. Decidi permanecer na educação infantil, pois era o trabalho que mais mostrava resultado e, por incrível que pareça, foi o que mais me dediquei a estudar. Lembro-me de como era "perdida" quando entrei no CEI, lá em Pirituba, CEI São João. As crianças me faziam de "gato e sapato". Eu não tinha ideia de como a rotina era importante, nem pensava sobre isso. Aos poucos, fui trocando com os meus pares, lendo mais sobre crianças dessa idade e aprendendo e testando novas práticas. 
Tenho uma parceria muito amiga, a Christine, professora também. Somos bem entrosadas e conversamos abertamente sobre nossas práticas. Percebo que tenho melhorado cada vez mais o meu foco na criança. Tento descentralizar de mim as funções, observá-las melhor e propor atividades do interesse delas.

No entanto, a cada ano procuramos renovar a parceria para trocar e aprender com novos parceiros, tarefa não muito fácil, mas possível. Este ano estou com a I, que tem grandes experiências com práticas no berçário e menos no MGI, pelo menos aqui no nosso CEI, onde foi volante por um bom tempo. Temos como características comuns a ansiedade, o que retardou um pouco o entrosamento da nossa prática. Nossas crianças são muito espertas e também têm ânsia em saber tudo. O que potencializa nossas características. Demorou um pouco, mas agora nosso trabalho parece ter encontrado um eixo, nos acalmamos. Também nos propusemos a desacelerar e a ensinar as crianças a fazerem as coisas com mais calma, está funcionando.

Agora, faremos menos em quantidade e mais qualidade. Retomaremos nossos registros que ficaram perdidos com tanta confusão. Pois agora sabemos o que vamos observar, aonde queremos chegar. Este ano eu sinto falta de uma parceira como o outro de agrupamento de MI. Aliás, isso é geral na escola. Nosso grupo é bem dividido pelas falhas e pela falta de comunicação. Gosto muito de trabalhar aqui, mesmo com os problemas que toda escola tem.

Sinto falta de um planejamento mais coeso, focado na criança.

$$
* * *
$$

\section{PROFESSORA P}

Como todo cidadão que vive em uma cidade como São Paulo, a rotina de trabalho profissional e pessoal é bem cansativa e agitada. Bom, me chamo $\mathrm{P}$, tenho 48 anos e trabalho desde os 17 dentro de unidades escolares. No início, trabalhei como professora de educação infantil na rede privada (3 anos); passei para a creche João Paulo XI (conveniada), desempenhando a função de coordenadora pedagógica, época em que as chamadas "pajens", que lidavam diretamente com as crianças e nós educadoras tínhamos a árdua função de transmitir nossos conhecimentos a pessoas que muitas vezes não tinham nenhum preparo ou mesmo aptidão para trabalhar com essa clientela tão pequena (3 anos); logo prestei concurso para o cargo de professor 1 no Estado e me 
efetuei na rede. Prestei novamente concurso para professor, agora na prefeitura (1992), e também me efetivei (EMEF Fagundes Varella); fui eleita coordenadora. Fiz novamente concurso, agora para diretor, mas quando fui chamada para assumir o cargo já me encontrava em "LIP" (licença para tratar assuntos particulares), morando em Recife e trabalhando no "Colégio Atual". Foram dez anos morando longe de São Paulo e então me exonerei. Após o regresso, tornei a me efetivar agora em EI. Adorei o cargo, a escola, as crianças.

Acho que nunca pensei que aprenderia tanto com essa faixa etária. Sempre comento que se eu fosse mãe de crianças pequenas teria dado mais liberdade, autonomia, autoconfiança aos meus filhos que hoje são pré-adolescentes (13 e 16 anos). Observo o tratamento de algumas mães em que a maioria subestima as capacidades de seus filhos pequenos, mas não julgo, pois fui igual. Hoje percebo como somos importantes no cotidiano de nossos alunos. Como nessa fase eles se desenvolvem, amadurecem, crescem e essas mudanças se tornam mais evidentes e eficazes com um bom trabalho pedagógico.

Adoro essa escola e meu trabalho!

\section{PROFESSORA V}

Trabalho desde os 18 anos na área da educação. Trabalhei por 11 anos na escola particular e há 14 anos estou atuando na escola pública. Até dois anos atrás atuava também no ensino fundamental. Atualmente, dedico-me à educação infantil. Gosto muito do que faço e aprendo cada vez mais com as crianças, trabalhar com crianças é sempre um desafio e é partindo desses desafios que reavalio a minha prática, trabalhar aqui no CEI Rio Pequeno e na EMEI CEU Butantã. Tinha uma filha de 4 anos e o que às vezes me angustia é que é difícil fazer cursos porque chega tarde em casa e esse ano, excepcionalmente, devido à greve tenho trabalhado aos sábados também. Procuro ser tranquila no meu dia a dia. Aqui no CEU temos desenvolvido projetos bacanas com as crianças, enfim... Esse é um pequeno registro da minha trajetória. 


\section{PROFESSORA I}

Meu nome é I, sou a segunda filha de minha mãe,primeira menina; portanto, ajudei muito minha mãe nos cuidados com meus irmãos e irmãs, sendo que no total somos em sete. Sempre fui muito cuidadosa e muito protetora com eles, defendendo e cuidando como se, na verdade, ao invés de meus irmãos, fossem filhos. Quando terminei a $8^{\mathrm{a}}$ série, entrei meio que de gaiato no CEFAM (Centro Específico de Formação e Aperfeiçoamento do Magistério), situado na Vila Gomez, onde fiz parte da $1^{\text {a }}$ turma. Lá, conheci pessoas maravilhosas e aprendi muito, já que éramos muito cobradas em relação ao comprometimento com o curso notas, estágios etc.

Foi nesse curso que aprendi a não me sentir diferente ou inferior a ninguém, desde que tenha argumentos suficientes para defender meus pontos de vista, aquilo que eu realmente acredito. Minha professora de história da Educação Katsue sempre nos falava que todos acordamos com nossos olhos e foi através dela que aprendi a ter mais confiança e segurança no que digo e no que faço.

Eu me formei em 1993 e no mesmo ano, no mês de novembro, trabalhei como substituta no Estado e, como criei vínculo, consegui a minha $1^{\mathrm{a}}$ sala de aula, um $1^{\mathrm{o}}$ ano. Foi uma experiência magnífica e, ao mesmo tempo, angustiante, pois, em julho, muitos ainda não sabiam ler e, com a minha falta de experiência, me apavorei. Foi então que meu diretor, Sr.M E. L., me disse que como um já sabia, cada criança aprende no seu tempo, mas que o famoso estalo surgiria em meados de setembro e, realmente, até o fim do ano, a maioria dos alunos, digamos $95 \%$ da sala, já estava alfabética. Foi a partir daí que todos os anos assumi uma sala e, como era a última, me deparei com várias séries e tive que me virar nos 30, ano após ano e que hoje posso dizer que nesses 20 anos já lecionei para o $1^{\circ}, 2^{\circ}, 3^{\circ}$ e $4^{\circ}$ anos do fundamental, EJA (educação de jovens e adultos), $5^{\circ}$ série e $6^{\circ}$ série em caráter excepcional, DM, DF, autista e Down na APAE e no “pequeno catálogo". Em 2000, entrei na Prefeitura de Cotia e, em 2006, na Prefeitura de São Paul. Foi entre 2000 e 2013 que me apaixonei pelo Ensino Infantil M6II, m6i e minha paixão os berçários, mas apesar de já ter se passado 7 anos, posso dizer que ainda estou engatinhando; pois o infantil requer muito empenho, já que surpresas surgem em demasia por mais cursos, leituras ainda é pouco; o que ajuda mais mesmo é o dia a dia, a evidência bem de perto e a troca de parceria a cada ano. 
Esse ano, estou trabalhando com a $\mathrm{O}$ e já aprendi muito; até mesmo estar mais aberta a mudanças. Estamos sempre refletindo sobre a nossa prática diária, tentando melhorar nosso trabalho e deixar as crianças mais confiantes, ousadas, autônomas, criativas, participativas entre outros.

Nosso CEI oferece possibilidades de trabalho materiais, espaço físico, estudos em grupo, e minha parceira sempre consulta o "amarelinho" para preparar nossas aulas. $\mathrm{Na}$ observação estou sempre aprendendo.

Em Cotia, também devido ao acúmulo, me ofereceram uma sala diferente uma sala diferente, uma sala de AEE (atendimento educacional espacial). No começo, me apavorei, não por atender crianças especiais, mas pelo fato de ter computador na sala e eu ter que manuseá-lo; porém, com cobranças e apoio de amigos e familiares, dei conta desse recado e hoje posso dizer que já sei curtir, comentar e compartilhar.

Espero poder um dia ficar com apenas a minha vida pessoal, como na parte da saúde e do profissional (cursos) e de minha família, e claro, ser uma pessoa menos ansiosa. Acho que já estou me conscientizando disso, fui até procurar um homeopata e estou fazendo um tratamento. 


\section{APÊNDICE C - Entrevista com a Professora O}

Gostaria que você começasse se identificando, falando seu nome, idade e suas experiências profissionais.

Meu nome é $\mathrm{O}$, tenho 31 anos, sou pedagoga e tenho especialização psicopedagogia institucional, faço atualmente uma especialização na área educacional, como professora eu tenho mais experiência no CEI mesmo. Trabalhei como professora de Ensino Fundamental I na prefeitura de Taboão e na prefeitura de Osasco, por 6 anos. O trabalho que eu mais me identifico é o do CEI.

Você poderia relatar um pouco do seu dia a dia aqui no CEI, explicitando como ocorre a comunicação entre você e as gestoras (coordenadora e diretora) e entre você e suas parceiras de sala.

Em relação à comunicação eu acho que é o fator que mais pega na escola, que mais atrapalha na organização da escola, principalmente porque as informações não batem, nem todas sabem o que está acontecendo. Falo da questão institucional como um todo. Em relação a gestão, eu só tenho uma boa comunicação com a coordenadora, porque ela fica no meu horário, ou seja, ela fica de manhã e a Diretora a tarde. Quem me da um apoio em relação a comunicação e sempre a coordenadora na orientação de como falar com as famílias onde e como resolver um problema uma orientação pedagógica mesmo de alguma coisa que está caminhando ela que dá as dicas. A Diretora, eu pouco vejo, tenho pouca oportunidade de dizer a ela minhas opiniões, porque a gente não se encontra as coisas acontecem mais do jeito do grupo da manhã na minha opinião. Com minhas parceiras a gente tem um caderno de comunicação às vezes eu chego um pouco mais cedo e consigo conversar com elas, muitas vezes não, às vezes é uma conversa de 5 ou 10min, elas passam como foi a rotina do dia, as ocorrências e pelo caderno de registro que a gente chama de Livro da Vida, ficamos sabendo o que elas fizeram com as crianças por esse caderno.

Você poderia relatar um pouco dos encontros de formação, dizendo se eles têm ou não um impacto sobre suas práticas e se permitem a troca de experiência 


\section{de práticas entre vocês. Você tem alguma sugestão para modificar o processo de formação?}

Eu acho que o PEA é muito engessado a gente determina no começo do ano como vai fazer qual a bibliografia que vamos seguir e somos obrigados a seguir, mesmo que no meio do caminho percebamos que não é o melhor caminho. Até podemos acrescentar um leitura, mas não tem como fugir do que esta na bibliografia. Mas o fato de ele acontecer acho que é uma oportunidade de estudo, tudo que eu leio eu tento trazer para prática eu trago para as crianças, só acho que o PEA falha na maneira como acontece, as vezes ele acontece despercebido e quando acontece ele acontece por obrigação, eu acho que deveria acontecer de uma maneira mais espontânea, acho que deveria melhorar. Tudo bem que a gente escolhe no começo do ano é para atender a necessidade da escola, eu acho que tem coisas que são de estudos e não estão na bibliografia do PEA, por exemplo uma coisa que aconteceu com a criança uma coisa que serve como experiência pra todo mundo, nunca pode abrir em horário de PEA, porque o horário de PEA não é horário disso, ou quando a gente precisa fazer relatório das crianças, tem professores que não sabem mexer no computador a gente deixa de fazer o que tem que fazer para fazer outra, então acho que isso não faz o menor sentido considero que o horário de PEA deveria ser mais aberto.

\section{O que você pensa sobre a organização dos tempos e espaços aqui na} instituição?

Eles são importantes para que a gente possa pensar nas interações com as crianças e na organização do espaço mesmo, não dá para lanchar todo mundo no mesmo tempo, por causa da questão do espaço no CEI, ele é pequeno, mas tem coisas que podem melhorar, uma sugestão da própria $\mathrm{V}$ até eu fiquei pensando era a questão de na hora do almoço as crianças terem a opção de sentar com quem quiser, porque pedimos para as crianças sentarem com a turma e ai a questão da livre escolha e cerceada porque o aluno é da escola, o aluno não é meu e ai a gente nunca deixa os alunos ficarem soltos, por causa do meu comprometimento com olhar, ou seja, se está comendo se não está, até a questão do banheiro, se está fazendo a higiene, se não está. Eu acho que todo mundo poderia ter um olhar para todos ao invés de ter um olhar fragmentado essa é uma das coisas mais marcantes. Acho que a tarde é muito tranquilo essa questão, nós não seguimos corretamente a rotina do jeito que nos combinamos a linha do tempo desde o começo do ano. Masnos preocupamos com as interações das crianças. Por exemplo, o 
parque está cheio, alguém percebe e sai, a gente troca os horários entre a gente. Podemos por exemplo, trocar o horário do lanche para inteirar com outra turma, na escola tem dois blocos um pessoal que janta primeiro e um pessoal que janta depois, então para que a gente possa fazer uma rotina diferente as vezes trocamos, eu acho que ser flexível assim é bom. Nós só precisamos ser mais organizados na relação da linha do tempo, de observar mesmo de fazer pensando nisso.

\section{Como é pensado o projeto político pedagógico?}

Dois dias, não tem a participação da comunidade de verdade, tem a participação do conselho, daqueles pais que estão no conselho, normalmente eles não opinam em nada até por falta de conhecimento mesmo. Mais se vai construindo junto é possível entender dar opinião se não se constrói junto não se entende nada. Está bom aquilo e pronto. Acho que tem que avançar muito a questão do projeto político pedagógico para participação até mesmo com os outros funcionários aqui da escola, porque esse ano, por exemplo, no período da tarde as meninas da limpeza sabem quem são cada criança, quais são as dificuldades, quem come melhor, elas colaboram mais do que as próprias ATEs, as meninas da limpeza como ficam de prontidão no banheiro no refeitório elas sabem mais sobre as crianças do que as ATEs que participaram pouco do trabalho desse ano.

\section{Como é esse processo de construção?}

$\mathrm{Na}$ minha opinião ele é falso ele segue mais ou menos do ano anterior ou alguma orientação que venha da DRE, a gente lê sim participa da leitura no sentido de revisão, nunca construímos de fato, ele já tem mais ou menos a cara da escola, então ele fica meio que deixado de lado, e depois não se cria coisas partindo dele, é só um documento e pronto.

\section{Em que medida o planejamento do trabalho com o agrupamento se relaciona} com o projeto da unidade?

Esse ano eu não fiz consulta alguma, o que a gente fez foi um planejamento por agrupamento, então eu me reuni com as meninas do outro mini grupo 1 em questão das linguagens, assim a partir desse planejamento eu segui o projeto com as crianças, mas do projeto político pedagógico eu nem vi a cara, só vi na hora da leitura, mas não 
necessariamente eu olhei para ele e me intencionei para fazer os projetos que são das salas.

Em sua opinião, quais os momentos da rotina diária aqui do CEI que você julga mais marcantes e por quê?

Obrigatoriamente marcantes são os horários da refeição e higiene, porque eles delimitam todos os outros horários, partindo deles eu consigo pensar no horário do parque, da atividade pedagógica eles vem primeiro, não necessariamente a gente tem um olhar tão dedicado nessa situação para o pedagógico, contudo, não dá para negar que eles são a prioridade da questão da organização da rotina , do planejamento eles que são os mais marcantes, porque dependo desses momentos para fazer as outras coisas.

\section{Como esses momentos aparecem no seu planejamento?}

Eles aparecem só citados, eles aparecem talvez nos meus registros diários, por exemplo, as crianças que estão desfraldando que vamos contando como foi o processo, mas planejar pensando nesses momentos não.

\section{Em que elementos da rotina você se apoia para planejar seu trabalho?}

A rotina marca a linha do tempo, então ela está presente em todo o planejamento, aliás a gente tem uma tabelinha e nela está registrada toda a linha do tempo do que acontece eu penso especificamente naqueles momentos que eu dediquei para o pedagógico, por exemplo a questão do cantinho, os projetos sequenciais ou aquelas que surgem no dia-a-dia.

\section{No que você pensa ao planejar o seu trabalho?}

Eu penso nas crianças no que seria melhor para elas, na verdade eu penso através do que eles trazem. Como avançar na pesquisa com eles. Quando não trazem nenhuma demanda, ou quando só uma criança que traz uma questão. Como é que eu posso fazer que isso se encaminhe para uma pesquisa? Para um planejamento de uma atividade? Porque essa questão da teoria e da prática que a gente tem que contextualizar, partir deles pra poder fazer, eu penso no que fazer com eles e fico tentando mesclar tudo isso. Nem sempre consigo, às vezes as coisas partem de mim mesma ou pelo menos foi eu que dei o ponta a pé inicial. Por exemplo, eu pensei muito nisso esse ano todos os anos a gente faz projeto de meleca com as crianças para eles terem oportunidades de 
explorar a tinta, perceberem com o que eles fazem marcas como eles são capazes de deixar marcas, e ai é uma proposta que vem sempre de mim, mas eu vejo que as vezes não é de tão ruim, porque o começo vem de mim, o resto eu vou encaminhando conforme a demanda deles, nunca o que eu planejei no começo sai como planejado. Eu não consigo cumprir e fazer tudo igual, no final sempre sai tudo diferente, porque mesmo que eu dê o ponta a pé, vou seguindo as demandas das curiosidades deles. A questão da exploração o que eles exploram mais ou que eles exploram menos, eu tento observar e seguir o planejamento.

Em que medida você consegue perceber a participação das crianças e das famílias no seu processo de planejamento?

Das famílias, de verdade eu pioro e melhoro nisso a cada ano, eu percebo que eles não participam da maneira que seria importante para as crianças, ativamente fazendo e entendendo o processo, mas em relação as crianças eu me esforço bastante para dar voz à eles e ouvir o que eles querem. Acho que isso eu melhorei bastante na minha prática, com relação as famílias, eu já escutei mais eles, mas ultimamente eu tenho escutado pouco, então eles participam pouco na questão da construção do meu planejamento ou da participação na execução das atividades. As crianças tem participado mais, questiono na roda o que eles querem fazer como eles querem fazer, a gente faz seleção de material, eu acho que nesse sentido eles participam mais. Contudo as famílias sabem pouco o que acontece aqui dentro eles ficam sabem em momentos específicos nos dias da família na escola. Acho que faltou eles participarem nem que fosse através de pesquisa ou trazendo uma curiosidade. A maneira que eles mais participam e dando informações da criança em casa, eles contam que foram passear os pais contam no caderno, trago essas informações para uma roda de conversa, acho que essa foi a única maneira .

Como você considera que o planejamento de vocês se encontra com o planejamento da outra dupla?

Eles não se conversam, porque a gente teve a brilhante ideia, eu que dei a sugestão de pedir a questão da linguagem porque a gente pensa que a criança fica o dia inteiro na escola e que as vezes só propomos roda de história porque o professor gosta muito de contar história e a coitada da criança fica 10h escutando história, sem fazer 
outro tipo de exploração, sem desenvolver outra atividade, por isso dividimos por linguagem, mas não falamos de coisas isoladas, por exemplo elas tem o projeto de animais e identidade eu e a I desde o começo do ano trabalhamos com projetos de pesquisa sonora, circuitos, e cantinhos, eles não se conversam esses planejamentos no sentido de um dar continuidade para outro ou trabalhar o mesmo assunto de forma diferente isso não.

\section{Como vocês se organizam para planejar as ações para o mesmo} agrupamento existe um planejamento comum para o mesmo agrupamento?

Ele é comum no sentido que a gente faz junto para saber o que o outro está fazendo, mas de se conversarem não, eles não se conversam. Por exemplo, elas fizeram a questão dos animais, tinham a ideia de fazer o projeto de animais, surgiu a questão do peixinho que a família contribuiu nesse sentido, trouxe o peixinho, eu converso sobre eles sobre os painéis que estão pendurados na sala, só nesse sentido de procurar saber o que eles estão aprendendo, mas aproveitar o tema para dar continuidade não eu não uso, eles não se conversam nesse sentido.

Em que medida você e sua parceira conseguem concretizar o que vocês planejaram para o período e quais as dificuldades que vocês encontram no desenvolvimento que foi planejado?

Acho que depende muito da minha força de vontade para se ter uma sequência do que faz, a gente procurou estabelecer cada dia da semana uma atividade para ser feita com as crianças, lá no começo do ano eu acho que o que atrapalhou muito foi o problema das faltas, porque foram muitas faltas da I e ai a gente não deu conta . Eu poderia ter dado sozinha, não é fácil porque são muitas crianças para um professor só às vezes as crianças foram dividas, ai existe um fator que tem a ver com você ter uma ajuda diferenciada de uma ATE ou de um professor ou as vezes para você receber ajuda você se agrupa com outra turma, então assim é difícil você da sequência ao planejamento. Nesse sentido, considero que o primeiro semestre mesmo com as faltas da I, pois ela tirou algumas licenças eu consegui me empenhar mais, até porque tinha uma volante disponível ela ficou na maioria das vezes no primeiro semestre, no segundo semestre eu não tive ninguém, muitas das vezes eu fiquei sozinha, as vezes foi a própria coordenadora que assumiu a sala comigo, outras vezes as crianças foram divididas em outras turmas, isso fez o trabalho perder muito, até mesmo de discutir com a I do que a 
iríamos trabalhar porque ela não estava aqui para discutir. A questão também da rotina das $6 \mathrm{~h}$, a gente trabalha $6 \mathrm{hs}$ não tem horário para lanche não tem horário pra nada. A I trabalha em 2 empregos, então ela vêm sempre com muita pressa e ela precisa muito almoçar, porque não dá para pessoa passar o dia sem almoçar, ou seja ,ela almoça no horário do sono das crianças que era um bom horário para fazer o planejamento. Os registros que a gente não faz diário, livro da vida, então eu acabo fazendo sempre sozinha, porque ela não está na escola nesse horário ou ela fica pouco tempo nesse horário ai não há tempo o suficiente para discutir, então isso foi bem ruim esse ano, atrapalhou na sequência das atividades .

\section{E como é que são tratados esses imprevistos no seu planejamento?}

Eu descobri que eu trato eles de maneira bem burrinha, porque eu sou metódica eu exijo de mim a questão da sequência e ai quando a sequência não acontece eu dou tudo por perdido. Não consigo enxergar no imprevisto as coisas que acontecem, então muitas vezes eu deixei de registrar coisas que eles faziam, porque eu não segui o que eu tinha planejado, mas até a $\mathrm{M}$ falou isso pra mim. As crianças continuam vivendo e é verdade, eu não fiquei fazendo nada com as crianças eu tive que improvisar e fazer outra coisa ou eu tentei fazer o que estava no planejamento mesmo que tenha dado tudo errado, às vezes a gente depende de material procuramos pegar material sempre no horário do sono, se você está sozinha não dá, acho que eu fui aprendendo a lidar melhor com a questão do imprevisto quando eu mudei meu jeito de pensar. Por exemplo, no segundo semestre eu dediquei ficar nos cantinhos, ele já era uma atividade permanente do primeiro semestre, mas ai eles foram atividades permanentes do segundo semestre de maior observação e através dos cantinhos eu fui complementando outras coisas para observação coisas que eu não fazia no primeiro semestre. Ele era uma atividade às vezes isolada e foi uma atividade principal no segundo semestre, comecei a dar conta e comecei a perceber outras coisas com as crianças.

\section{Como vocês trocam informações entre os períodos?}

Pelo caderno de comunicados que a gente vê as ocorrências do dia e pelo livro da vida que elas registram a atividade que fez na manhã e como ela aconteceu. Nós sempre lemos no começo do dia para poder saber o que eles fizeram de manhã. 
E no livro da vida a que você se referiu. São registrados o que as crianças fizeram todos os dias, ou esses registros são pontuais?

São pontuais, mas todos os dias tem alguma coisa para dizer de alguém, então eu procurava fazer diariamente ele também foi se perdendo sobre a questão organizacional, por exemplo, tem registro dele de outubro que de lá pra cá foi bem difícil, mas eu tentei em outubro fazer de uma maneira mais pontual, porque todos os dias acontece alguma coisa pra você contar, depois eu perdi novamente, por conta da questão organizacional, mas eu acho importante registrar.

\section{Como vocês trocam experiências de prática?}

Pelo livro da vida, ou quando eu consigo chegar um pouco antes, mas é bem assim não é o ideal pelo livro da vida porque mesmo que a gente tente registrar o que aconteceu não consta o que pensamos sobre isso sobre como vamos fazer para melhorar e isso a gente não conversa. Eu acho que eu sou das quatro a que mais fala disso, a $\mathrm{P}$ até falou isso pra mim, mas falta essa troca do que eu estou pensado lá pra frente. Já fiz agora não deu, agora foi legal, então não dá para incrementar a gente não põe no livro da vida. Sou a que mais põe, então elas ficam mais por dentro disso. Delas eu fico menos com registro do que aconteceu e mais com uma descrição. Uma coisa que eu mudei também é procurar interferir no registro delas, elas escrevem alguma coisa, por exemplo sobre o peixinho. Eu escrevo depois para elas em baixo o que as crianças falaram a tarde e sugiro alguma coisa diferente até porque as vezes eles fazem a mesma coisa da tarde mesmo a gente planejando pensando em linguagem diferentes. 


\section{APÊNDICE D - Entrevista com a Professora P}

\section{Gostaria que se identificasse dizendo: nome, idade, formação e experiências} profissionais.

Meu nome é P tenho 48 anos, eu iniciei a minha carreira sendo professora em escolinha de educação infantil, depois eu fui coordenadora de uma creche conveniada, daí eu ingressei no Estado. Mais tarde, eu ingressei na Prefeitura, ambos no ensino fundamental. Como eu precisei me ausentar de São Paulo durante uns anos, eu retornei para a Prefeitura e aí me efetivei neste cargo na educação infantil. No começo, eu estranhei um pouco, porque eu estava acostumada com o EMEF, mas logo me apaixonei por esta faixa etária.

Queria que você me contasse um pouquinho do seu dia adia aqui no CEI, explicitando como ocorre a comunicação entre vocês e as gestoras (Coordenadora e Diretoras) e entre vocês quatro.

Bom, o CEI tem uma rotina fechada, a gente não pode dizer que é uma rotina aberta. Ele têm horários, a gente tem que programar os nossos horários sempre de acordo com as outras salas para que não haja muito atropelo, é muito excesso de criança, mas procuramos no nosso dia a dia sempre planejar atividades que divirtam as crianças, que os distraiam e fiquem relaxados, que os deixem felizes. A gente fala que o importante na atividade é ver a carinha deles, a carinha de alegria, a satisfação por estar desenvolvendo este trabalho já que eles ficam 10 horas aqui na escola. Então é importante, desenvolvermos um trabalho que realmente satisfaça aquela faixa etária que a gente está trabalhando. A nossa relação com a nossa coordenadora foi razoável porque houve problemas de acomodações e horários, então a nossa coordenadora trabalhou praticamente no período da tarde, não tivemos muito contato com ela. Geralmente, quando ela chega é a hora que estamos colocando as crianças para dormir e daí, quando eles estão dormindo, é ruim você sair da sala, porque é importante também essa supervisão na hora do sono. Então a gente não teve muito contato com a coordenadora nem mesmo na hora no PEA, nosso trabalho ficou mesmo bem fragmentado pedagogicamente falando. Com a diretora, a relação é muito boa. A gente conversa 
muito e não tivemos problemas em relação à direção, mas em relação a essa parte pedagógica ficou um pouco a desejar sim, e em relação a nossas parceiras eu também não posso dizer que foi uma coisa plenamente satisfatória, porque nos encontramos em um momento que uma está chegando e a outra está saindo, conversamos geralmente por alguns minutos . É difícil a gente ter uma reunião em que as quatro estejam juntas, geralmente a gente faz nossas comunicações por um caderno, em que colocamos mais os registros das ocorrências do dia, mas uma coisa que a gente se pega que é realmente a parte pedagógica do desenvolvimento da criança, a gente acaba não colocando nesse caderno de ocorrência. É uma coisa ou outra quando se destaca como um aluno que a gente tem, o $\mathrm{V}$, se você observou, ele não falava tanto, ele estava com um comportamento um pouquinho diferenciado da turma, então, neste caso, a gente fazia um registro mais pedagógico das conquistas e dos desenvolvimento do V. Agora geralmente são mais as ocorrências mesmo, então é bom, não é ruim, mas não é uma coisa que eu falo assim que é satisfatório, porque não é. Acho que as nossas trocas são só por papéis também não tem muito tempo para registros. Os nossos registros são realizados enquanto eles dormem, mas também temos que dar atenção especial neste momento porque não é porque eles estão dormindo que não precisam de atenção. Um demora um pouco a gente vai um pouco fica pertinho então quando você vai ver mesmo o tempo efetivo que eles dormiram você faz alguma coisinha, mas mesmo assim é fazendo no papel e olhando pra eles. Você nunca pode tirar atenção principalmente na hora do sono, porque a gente sabe que é uma hora que você tem que estar atenta a tudo.

\section{Eu queria que você relatasse como você vê a formação aqui no CEI, dizendo} se ele tem ou não impacto na sua prática, se eles permitem as próprias experiências entre vocês e as professoras, e também se você teria alguma sugestão para mudar esse processo de informação?

Então, o nosso processo de formação eu acho bom, mas eu não vou me basear por este ano, porque este ano não foi bom, o ano que vem vai mudar, a nossa diretora atual está saindo, então eu acho que a nossa coordenadora vai conseguir montar seus horários, agora e ela vai poder estar acompanhando os dois horários de PEA. No próximo ano, acho que vai mudar eu não posso me basear neste ano, vou falar um pouquinho da nossa prática dos outros anos. Sim, eles têm um impacto muito grande principalmente porque quando a gente desenvolvia um trabalho no PEA, a gente estava trabalhando com a parte de currículos, então focávamos matemática. O que a gente fazia? A gente trabalha 
teoria, depois ia para prática, depois fazia apresentações para os nossos amigos, porque às vezes você está tão enraizada em uma prática que às vezes você acaba tendo tantas ideias e quando um parceiro relata um trabalho que ele desenvolveu você fala: "nossa, que bacana", daí você vê aquele trabalho dele e começa a refletir em cima, ter outra ideia em cima daquele trabalho naquele mesmo trabalho, você melhora seu foco, então a gente sempre foi acostumada a fazer isso, e isso, esse ano, fez muita falta. Não teve muito essas trocas dê experiências, então a gente só ficou com a parte teórica só lendo, lendo, realmente não foi legal. Nos outros anos nós fizemos isso, foram muito interessantes essas trocas e sempre preparava todo o material que íamos apresentar para o nosso grupo, a gente desenvolvia como um grupo as atividades não era só falar, porque era muito importante o professor vivenciar a atividade como criança.

\section{Eu gostaria de saber o que você pensa sobre as organizações dos tempos e} dos espaços da instituição como um todo?

Quando a gente trabalha com as crianças do mini grupo 1, ou do berçário, eu acho mais fácil você respeitar o tempo e sua linha de atividade, mas quando você está no mini grupo 2, meu Deus! Como é difícil, né! É meio que fechado mesmo o mini grupo 2. Eu tinha uma sala que eles não queriam dormir, muitos alunos! Achava cruel deixar aquelas crianças deitadas no colchonete e você não pode dizer não vou colocá-los para dormir porque eles não querem mais dormir, eles são obrigados. Em algumas coisas que eu acho difícil você mudar em uma escola porque se eles fizerem barulhos as crianças que querem dormir não conseguem dormir, então tem algumas coisas que por mais que você queira mudar é difícil ,você sempre vai atrapalhar alguém. Por exemplo, eu não tenho a disponibilidade de escolher a hora do almoço, se tiver que prolongar uma atividade que está muito interessante eu não posso almoçar depois, porque eu vou atrapalhar o horário da cozinha. Tudo muito fechado.

\section{Como é pensado o projeto político-pedagógico aqui da unidade?}

Pensado, discutido e rediscutido todo início de ano e sempre acaba fechando as mesmas ideias, fechando as mesmas posturas. O projeto é sempre aquela mesma coisa: os horários, a linha de tempo de cada sala, sabe, tem muita abertura para projetos. A gente pode no começo do ano apresentar os projetos que a gente quer desenvolver durante o ano, a gente tem essa liberdade, mas em relação à linha de tempo, isso não. 
Em relação à temática que foi tratada este ano no projeto político, vocês que definiram?

Então, a gente sempre olha as recomendações curriculares e a gente não foge muito da "amarelinha". Isso a gente tem que ser sincera.

Em que medida o planejamento do trabalho com o agrupamento se relaciona com planejamento de vocês e como esse planejamento se relaciona com o projeto político do CEI?

Tudo nós conversamos porque a gente procura sempre temas gerais, por exemplo, quando escolhemos o projeto animais, porque no projeto animais nós teríamos um ano para trabalhar um monte de coisas, a temática dos gráficos a gente tentou deixar separados as áreas entre períodos da manhã e da tarde, mas com foco, não que a gente não trabalharia, deixamos o projeto de maneira que a gente consiga trabalhar com todas as áreas aí a gente dá focos no sentido de registros, no sentido de observações de todos os projetos até agora, procurando envolver todas as áreas em uma temática.

\section{E o projeto político deste ano gira em torno de qual temática?}

O nosso projeto não teve uma tema específica este ano, tiveram anos que a escola toda trabalhou no mesmo projeto, por exemplo, os indígenas, a Europa e o mundo dividindo por regiões e trabalhando por temáticas, por exemplo, a África, utilizando filmes, a própria região, savanas, e fizemos apresentações para as outras salas, mas este ano a proposta foi somente trabalhar o currículo.

Em sua opinião, quais os momentos das rotinas diárias do CEI que você julga marcantes e por quê?

O parque, as atividades dirigidas que eles gostam muito, mais eu acho que quando a gente desenvolve atividades na sala na construção do jogo, quando a gente faz uma coisa mais especifica eles têm mais interesse e satisfação para estar desenvolvendo aquilo depois brincar com aquilo pronto, acho que eles devolvem muito para gente quando propomos uma atividade pra eles, o interessante é que a cada ano eu noto que as crianças estão mais evoluídas em suas respostas.

Como é que esses momentos que você julga marcantes entram no seu planejamento? 
Temos o livro da vida, aliás, eu deveria ter um gravador desse (risos), geralmente as falas deles são anotadas, por exemplo, isso foi feito com o V nesse momento é legal os registros. Mas é isso. Quando você me perguntou dos registros eu pensei nos registros de uma forma geral no dia a dia do começo do nosso dia nem do dia dele, então isso lógico é difícil, porque o interessante seria ter aquele tempo quando você para você faz todo o registro de tudo, a gente pega o momento que a gente acha mais interessante que geralmente é um momento da atividade dessa atividade que a gente a faz em cima dos projetos se você perguntar assim será que é por causa do olha pode ser o foco que eu estou dando, por exemplo, já aconteceu de eu achar bem interessante o momento de atividades dirigidas lá fora e eu também ter esse olhar então de repente uma vez eu gravei a brincadeira da serpente e não precisou da gente para brincar isso significa que a gente brincou com eles e eles gostaram dessa atividade eles mesmos desenvolvem essa atividade sozinha, foi bem interessante um dia quando a gente foi trabalhar ritmo com bastão com eles, nossa foi bem bacana eles adoraram gravei tudo, então isso às vezes é o nosso foco, então geralmente eu acho que isso é o que a gente consegue parar mais vai ver que é por isso e já se preparar para fazer esse registro para e fazer esse registro de parar e registrar, então é a hora da roda então é interessante e a criança primeira vez que a gente ouviu a voz do V falar foi em uma devolutiva da biblioteca e ele falou direitinho o livro que ele tinha lido com a mãe, a gente nunca tinha escutado ele falar ai ele falou alto o nome do livro, nossa foi super legal, porque a mãe dele disse que ele fala, mas realmente na escola ele não fala e o dia que a gente faz a chamada e ai ele não fala presente ai um dia ele falou presente ai a gente corre faz o registro, mas não é aquela coisa que eu acho que é um bom registro.

\section{Como que você ver a rotina do CEI no seu planejamento e em que elementos}

\section{você se apoia para planejar?}

A gente sempre olha nosso planejamento e tenta colocar ele na nossa rotina, mas eu me apoio nesse planejamento tento coloca-lo em nossa rotina, porque tem coisas importantes para trabalhar com cada faixa etária, isso a gente discuti muito no Cei pra eles não ficarem na mesmice. Então procuramos trabalhar muito, no MGI damos continuidade ao trabalho que era realizado no berçário para não fazer as mesmas coisas em todos os anos. A roda de conversa por exemplo, é uma atividade matemática procuramos sempre propor novos desafios a cada faixa etária pois se não discutirmos o 
que vamos trabalhar em cada faixa etária a gente acaba tendo que trabalhar do começo ao fim sempre a "A Galinha Pintadinha" que é o que eles mais amam.

\section{A rotina no planejamento é uma coisa que aparece fechada ou é uma coisa} mais flexível?

Acho fechado, a gente tem sim uma rotina fechada e não posso falar pra você que eu acho que é aberta. Quando a gente está lá em baixo no Mini-Grupo II é um pouquinho mais flexível, porque se eu não quiser tirar minhas crianças para o parque e esse dia eu desenvolver um trabalho em sala fica mais fácil. Quando trabalhamos no Mini-Gupo I e com duplas é mais complicado porque procuramos usar todos os espaços é o que eu estou te falando eu e a V ainda temos essa característica que a gente muda muito, mas, por exemplo, eu estou desenvolvendo um trabalho aqui no lactário já que a gente não tem mesa e de repente eu necessito de mesas para aquela atividade porque eu estou trabalhando com pintura e já está tudo montado aqui, tudo arrumado, não tenho muito essa abertura pra poder desenvolver meu trabalho é o que eu estou te falando, eu adoro a escola, mas eu vejo que a nossa escola não é assim tão flexível. Você desenvolve seu trabalho, mas meu Deus se você da uma falha, por exemplo, dez minutos a mais na sala do vídeo outro professor quer vir para sala dele é briga é confusão, então eu estou desenvolvendo das 09h00min as 10h00min do meu horário eu posso usar aqui esse espaço pra eu fazer as atividades, se for 10h05min e eu não sair já da confusão, nesse sentido eu não posso falar que as pessoas são flexíveis, porque não são.

\section{Em que você pensa ao planejar o seu trabalho?}

Quando eu penso na minha prática eu penso em fazer atividades que eles gostam que eles sintam prazer em fazer, porque eu não vou mentir não, já trabalhei em um lugar que você dava a atividade para criança e se ela estava mexendo com uma meleca, não podia se sujar então ela tem que ficar bem atenta. Isso não tem a mínima graça e ai você vê que só está dando por dar a atividade, porque está lá no seu planejamento, porque você vai trabalhar com a meleca. Você não vê alegria nenhuma na criança só bronca, grito "não mexe", coisas assim. Quando a gente pensa em dar as atividades uma das coisas que eu olho muito são as fotos, a alegria deles ,a satisfação, porque para você fazer a atividade só por fazer pra dizer que você está fazendo não adianta . Mas quando olha a foto e olha a cara deles e está todo mundo quieto parado, não tem a mínima 
graça. Então eu penso muito nisso no prazer eu acho que eles têm que fazer as coisas com alegria e o professor também acho que é importante. Acabei de fazer um curso foi bem interessante ai então até a postura dos professores a gente trabalha com educação infantil, jogos e brincadeiras, o tema do jogo você tem que vir aberto, você tem que vir de tênis, de legging, porque é a nossa prática, a atividade o curso só foi de prática, o professor não quer participar de nada. Ele é um professor de educação infantil ele está indo para um curso que é jogo e brincadeiras e saberes da educação infantil e ele não quer participar de nada, o que ele está fazendo ali? Eu vejo muitas posturas assim, então não tem a mínima graça, a professora tem que ser criança em alguns momentos, brincar como criança. Você tem que ser alegre em muitos momentos, você tem que estar aberto para desenvolver uma atividade realmente prazerosa o prazer é tudo, as atividades tem que ser prazerosas.

Em que medida você consegue perceber a participação das crianças e das famílias no seu planejamento?

Nosso planejamento é voltado para as crianças, às famílias eu acho que elas colaboram sim, principalmente quando a gente tem uma devolutiva como a gente teve na mostra que os pais vêm, falam, eu acho que os pais prestam muito atenção, e fazem muita comparação entre as crianças. É bem perceptível como a criança do CEI é bem mais desenvolvida do que uma criança que não vai para escola. Sei porque já fui mãe, em um momento que eu não trabalhava na educação infantil ,já tinha trabalhado sim há muitos anos, mas não trabalhava mais há muito tempo, hoje eu vejo que meus filhos têm mais capacidades, porque eu vejo crianças fazendo coisas que eu não achava nunca que meus filhos poderiam fazer nessa idade, então considero que eu tratei meus filhos muito como bebes. Quando entrei aqui, minha filha tinha 4 aos, eu tinha aluna que tinha 3 anos, ela amarrava sapato e minha filha vivia escutando que eles não colocavam nem o sapato, então eu acho que eles percebem muito isso. Colocamos muito isso em reunião para os pais. "Pai, quando você ver a blusa dele socada na mala, tenta lembrar que a gente faz um trabalho deles tirarem a blusa". Priorizamos a autonomia é o fazer deles, incentivamos colocarem meia, sapato, e tentamos mostrar isso para os pais. Acho legal que a gente mostre o nosso trabalho para os pais e eles dão valor, teve uma vez que eu falei para o pai assim: "às vezes o pai coloca o sapato tão difícil na criança que nem a criança sabe colocar, como que a gente vai dar autonomia”. Eles dão bastante valor no nosso trabalho, quando a gente fala sobre as nossas conversas, então a gente 
procura colocar os pais nas atividades temos uma comunidade participativa, isso é muito positivo, dão bastante devolutivas no caderno, isso é bem bacana.

\section{As vozes das crianças são consideradas no planejamento?}

Sim e é por isso que a gente tem os cantos, nos cantos a gente consegue observar bem isso, mais isso, as crianças não fazem conosco, fazem com as professoras da tarde as escolhas dos canto são feitas de acordo com a escolha deles, isso é bem interessante também porque eles têm aquela autonomia de escolher as atividades que querem desenvolver nos cantos e a própria mudança desses cantos. Esse ano foi muito positivo, eu não trabalhava com dessa maneira eu nunca trabalhei, mesmo lá em baixo, porque lá tínhamos a falta de espaço, a sala era muito pequena, já essa sala é uma sala maravilhosa um tamanho maravilhoso. Eu não tinha preferência dos cantos assim, eu confesso que achei maravilhoso, foi um trabalho muito bom feito no período da tarde.

\section{De manhã vocês não exploraram esse espaço?}

Muito, eles foram muito explorados, mas acho que o foco do canto é do período da tarde, elas fazem a organização achei bem interessante esse momento deles fazerem escolha, achei bem bacana elas sempre falam das devolutivas dos nossos alunos eu também eu acho isso bem legal. Temos momentos das devolutivas deles, em relação ao que foi feito no período oposto às vezes a devolutiva é menor no período da manhã porque eles já vão para casa, eles já dormiram, mas mesmo assim a gente tem a devolutiva do que acontece a tarde que também é interessante.

Como o planejamento de vocês ( $P$ e V) se encontra com o planejamento das colegas do mesmo agrupamento (O e I)?

Mais através do nosso semanário, fazemos toda segunda feira e elas fazem na sexta, temos, ou seja, já sabemos o que vai ser trabalhado a tarde elas também veem o que vamos trabalhar de manha. Às vezes é mais fácil até a devolutiva, porque sabemos o que aconteceu. É lógico que acontece de planejarmos uma coisa e no dia, mudamos, até mesmo pelo interesse deles. Já aconteceu isso de a gente começar uma atividade um dia e cada dia faz uma coisa, um dia a gente foca nos projetos animais outro dia a gente foca em vídeos, musicas, daí a gente rasura escreve "não houve por conta disso e 
disso", mas mesmo assim elas conseguem saber o que está acontecendo de manhã e a gente à tarde.

Como vocês se organizam para planejar as ações para o mesmo agrupamento, existe um planejamento comum?

Não, eu não vejo esse planejamento comum, eu vejo assim: nós trabalhamos com o nosso planejamento elas com o delas, mas ações mesmo eu não consigo enxergar, porque não temos momentos de troca em relações a isso. Não temos mais esse horário de parar, antigamente tínhamos, fazíamos nossas reuniões pedagógicas e conseguíamos um agrupamento maior, mas cada vez é mais difícil, as pessoas tem todos os seus compromissos e acabam tendo suas atividades nos períodos da manhã e atividades com os períodos da tarde, geralmente quem fazia essa interlocução era a coordenadora mais esse ano por conta dos horários dela ficou inviável, então a gente não tem muito essas trocas.

Em que medida você e a $\mathrm{V}$ conseguem desenvolver o que planejaram e quais dificuldades vocês encontram nesse percurso?

Como fazemos o semanário na segunda-feira, temos meio que planejado o que vamos fazer, não temos tanta dificuldade. O que vamos precisar de material, livros... já vamos separando tudo isso antes então, por exemplo, tal dia a gente vai precisar de tal material, tal dia a gente vai precisar de papelão, já planejamos até atividades para 15 dias adiante. No dia em que falamos em fazer atividades com caixas já estava planejado para 15 dias, mas já estávamos preparando. Viemos pensando mesmo, isso eu não vou mentir para você que é bem bacana, tinham as duas caixinhas e a gente viu a briga que foi percebemos que eles queriam brincar com a caixa e como é legal brincar com caixa e nos ficamos duas semanas. Pegamos em supermercado a gente encheu aqui de caixas, o dia que a gente ia trabalhar com a caixa foi bem interessante. Depois fomos levar a caixa lá para o reciclável, já aproveitamos e falamos da reciclagem com o papel tudo lá mesmo no estacionamento, mas mesmo assim recebemos críticas, porque a criança não pode ficar no estacionamento, mas não estávamos à toa, estávamos falando de reciclagem, às vezes tem umas críticas que são algumas coisas que você faz.

\section{Como é que são tratados os imprevistos nos planejamentos de vocês?}


Imprevisto sempre temos, não tem como, replanejamos e pronto, vemos alguma coisa que é de interesse deles e trocamos a atividade, não tem muito isso com a gente, não tem muito essa coisa fechada que tem que ser aquilo e acabou, por exemplo, eu fiz um negócio hoje e a gente os levou para assistir hora de natal, porque eles estavam pedindo, então eu fui pegar a televisão mais outra professora já havia pegado para o berçário descemos lá para baixo e pronto porque tem uma televisão lá em baixo, então, acho legal essa dinâmica de estar mudando isso é bacana, aliás, isso é o ideal você poder estar explorando todos os espaços da escola, às vezes é um pouco difícil lógico, temos que respeitar a linha de tempo de todo mundo, mais acho bem bacana quando tem um professor do mini grupo 2 que vira e fala assim: "P podemos subir para usar a sua sala?" Esse ano já vieram duas professoras mas é interessante, é legal você dar essa abertura, porque não podemos monopolizar as coisas, às vezes tem gente que monopoliza sim é tudo dá escola pode pegar sim, e o que eu acho bem legal também esse ano foram às salas ambientes considero muito interessante isso, porque eles exploram todas as salas acho que isso é uma coisa assim que tinha que acontecer em todas as escolas, porque é muito bacana, é o momento de autonomia deles irem para aquela sala fazer atividade ali se misturarem entre eles e realmente fazer atividades que eles queiram fazer.

\section{Como vocês quatros trocam informações, quais são os mecanismos que}

\section{utilizam?}

São os cadernos, aqueles dois minutinhos da entrada e da saída a gente só fala as coisas básicas. Usamos mesmo os registros nos cadernos e o nosso livro da vida, porque elas conseguem ver como estão acontecendo nossos registro, pelo livro da vida.

\section{Eu queria saber como que vocês trocam experiências de práticas?}

Da mesma maneira, eu acho que hoje o nosso registro mais importante é o livro da vida que é ande a gente vê a prática delas, os desabafos, porque é um livro para nós mesmas é o lugar que colocamos o que realmente está acontecendo no nosso dia a dia , o problema é que nós temos muito registro, a gente tem o diário que colocamos aquelas coisas das atividades que foram desenvolvidas, ai tem o semanário, a gente tem livro da vida e tem o livro de comunicação que é esse que a gente coloca as ocorrências, então nós temos quatro, o ideal seria se a gente conseguisse compensar tudo em um só. 


\section{APÊNDICE E - Entrevista com a Professora V}

\section{Gostaria que se identificasse dizendo: nome, idade, formação e experiências} profissionais.

Meu nome é V, tenho 37 anos, estou há 14 anos na Prefeitura de São Paulo, iniciei minha carreira em uma escola particular onde trabalhei por 11 anos depois ingressei na prefeitura, fiz outro concurso para escola pública, trabalhei bastante tempo no ensino fundamental e estou há nove anos na educação infantil.

\section{Queria que você relatasse um pouquinho sobre seu dia a dia profissional?}

Fiz pedagogia, magistério e fiz pós-graduação na PUC uma especialização para professor de educação infantil a $4^{\text {a }}$ série, foi minha primeira pós, depois fiz psicopedagogia, tenho duas pós, fiz minha graduação na Universidade São Marcos.

Trabalho no CEI Rio Pequeno pela manhã, saio às $13 \mathrm{~h}$ e vou para EMEF, trabalho lá das $15 \mathrm{~h}$ às $19 \mathrm{~h}$ e algumas vezes por semana eu entro mais cedo para fazer hora atividade lá faço a menor jornada, porque aqui eu tenho uma jornada maior de $30 \mathrm{~h}$.

\section{Como ocorrem as comunicações entre você e as gestoras (Coordenadora e} Diretora) e entre você e as outras professoras do agrupamento em que trabalha?

Com a coordenação esse ano foi mais difícil, porque coordenadora acabou ficando só no PEA da tarde de manhã a gente faz o PEA com a Diretora nos comunicamos mais quando a coordenadora chega porque ela passa nas salas da os informes ou deixa por escrito no livro de comunicação pedagógica. Com as meninas da tarde a gente conversa um pouquinho de forma breve na troca de períodos, mas procuramos deixar o máximo de registro possível no caderno de comunicação e também no nosso livro da vida. Vemos um pouquinho do trabalho delas à tarde no semanário também nesse livro a gente vai registrando colocamos as atividades que deram certo e as que não deram e como vai cada criança, a gente costuma cada uma ler uma da outra também. 
Gostaria que você relatasse um pouquinho sobre os encontros de formação (PEA), dizendo se eles têm ou não impactos na sua pratica se eles permitem a troca de práticas entre as professoras e se tiver alguma sugestão para mudar essa configuração da formação que você diga também.

$\mathrm{Na}$ verdade o encontro de formação foi um ganho para nós profissionalmente tivemos um momento de sentar, estudar, de ler , foi uma luta grande para nossa categoria, de repente hoje nos incluímos isso na nossa jornada, então eu acho que os PEAs refletem sim na nossa pratica é o momento que a gente estuda que a gente pega ideia a gente avalia o PEA contribui para o trabalho do professor sim. O que eu vejo como sugestão e do coordenador acompanhar esse PEA porque é ele que acompanha a parte pedagógica, então o que eu dou de sugestão é isso que de repente a gente consiga voltar essa questão do coordenador pedagógico acompanhar, porque eu acho que ele que faz essa mediação esse elo com o trabalho dos professores.

O que você pensa sobre a organização de tempos e espaços daqui da instituição. $O$ que você considera dessa organização?

Essa sala do mini grupo que nos trabalhamos que tem esses cantos considero essa organização do espaço positiva, acho que, por exemplo, a gente vê a criança que trabalha com essa organização do espaço na sala de um jeito e quando vêm criança de fora percebemos eles se comportando de outro modo, por exemplo, os nossos que construíram esses jogos eles usam de maneira diferente .Vimos outras crianças brincando totalmente diferente da forma que os nossos alunos brincam, porque eles construíram, eles que fizeram o jogo da memória, eles fizeram o quebra cabeça eles sabem jogar, eles sabem como funciona, então essa organização do espaço me marcou bastante esta construção com as crianças, outra organização de espaço que eu gosto bastante são esses circuitos que a gente faz juntos todas as salas, essas salas ambientes que eles transitam entre os espaços aqui em cima tranquilamente.

\section{E quanto aos tempos?}

Essa questão do tempo também marcou bastante pra nós, primeiro conhecemos as crianças e aí apareceu o peixinho que foi o Pai que doou e a gente começou nosso projeto animal a partir do que a criança trouxe então a gente faz isso mesmo nos estávamos um dia com tudo organizado uma professora trouxe uma tartaruga marinha, 
nos paramos tudo para inserir traçamos mais ou menos o que vamos fazer mais respeitamos o tempo da criança, não é aquela coisa tão fechada, se a criança trouxe uma coisa bacana à gente não vai deixar de explorar porque temos outra coisa para fazer .

\section{Sobre o projeto político pedagógico da unidade como que ele é pensado?}

Todo ano sentamos, olhamos para ele e fazemos juntos, tem esse trabalho de construção sim, é uma coisa que vem de baixo para cima, então você pode mexer, você pode olhar, você vai adaptar a coordenadora da até um tempo para começar o ano e pensarmos o que vamos fazer, sentir sua turma, o que nos vamos mexer aqui ali. Ele é construído com coletivo sim, não e uma coisa que vem de cima para baixo.

Em que medida que esse planejamento de vocês se relaciona com o projeto político da unidade?

Inserimos no nosso trabalho e no nosso planejamento no inicio do ano a gente deixa mais ou menos já traça já deixa a justificativa tudo no projeto político pedagógico que vai junto a ele. A coordenadora sempre pede os nossos planos de ação ate os nosso projeto pequeno que a gente vai desenvolver colocamos junto com o projeto político pedagógico.

Em sua opinião quais os momentos da rotina diária aqui do CEI que você julga que são mais marcantes e porque são marcantes?

Acho que um dos momentos da rotina do CEI mais marcante é a questão de brincar, eu acho que as crianças, por exemplo, parque, campos dirigidos, nos circuitos, nessas salas ambientes esse momento que a criança circula que se relaciona mais com o outro são momentos mais marcantes, porque é muito tempo que a criança passa aqui dentro da escola, acho que está questão de brincar, da socialização esses momentos marcam mais na vida das crianças, porque em casa praticamente não tem contato com a família, pra mim o que marca mais é o brincar, esse momento que eles estão interagindo um com o outro.

\section{Como esses momentos aparecem no seu planejamento?}

Aparecem todos os dias, esse ano, principalmente de manha a gente deu mais autonomia para essa criança brincar. Eu sentia antes que eu tinha um planejamento mais 
voltado para brincar a gente deu uma liberdade, uma autonomia maior para as crianças, para olhar mais, ver está criança brincando, dar liberdade para essa criança escolher aonde ela vai. Essa conversa com as crianças, essa escuta, senti que foi mais presente, antes eu me sentia mais mecânica.

Como é que você concebe a rotina no seu planejamento, em que elementos você se apoia? Temos o semanário que a gente faz, lá contemplamos essas coisas fixas, por exemplo, parque, café, almoço então, por exemplo, o projeto animal a gente deixa para um dia, os nossos projetinhos a gente vai dissolvendo, então tem o dia do vídeo, nós vamos acrescentando nessa parte fixa da rotina, intercalando.

\section{No que você pensa na hora de planejar seu trabalho?}

Eu e a P este ano foi muito bacana na hora de planejar. Por exemplo, está semana na segunda- feira foi o dia do projeto animal, deu certo a gente está fazendo uma coisa hoje se foi bacana já acrescentamos outra, a gente vai enganchando. O que deu certo já vamos focando na próxima semana.

Em que medida vocês conseguem perceber a participação da criança e das famílias no planejamento. Em que medida elas participam?

A participação das crianças acontece quando vemos como eles estão indo se estão respondendo ou não estão. Para as famílias nós mandamos algumas atividades para fazerem em casa, por exemplo: "mãe, na segunda-feira faremos uma roda para discutir sobre família, desenhe a família de vocês". Mais ou menos nesse sentido que nos usamos a participação da família, desenhar, registrar algo para discutir com as crianças, então esse momentos nos incluímos a família.

\section{Como seu planejamento se encontra com os planejamentos das suas colegas} do mesmo agrupamento?

Dividimos as linguagens, por exemplo: trabalhamos linguagem oral, elas focam mais a matemática, nós as artes, elas o movimento, porque a criança fica integral. Desde o ano passado que eu fazia dupla com a $\mathrm{O}$, dividimos as linguagens, não que a gente não trabalhe também circuitos, que não trabalha matemática, mas não é o nosso foco. Isso faz com que não fique tão cansativo para as crianças. A biblioteca itinerante por exemplo, a gente faz os empréstimos, mas como a gente fica com a linguagem oral nos só fazemos a devolutiva, na segunda-feira, então elas fazem empréstimo e nos 
fazemos a devolutiva. Essa questão da fala como está, quem leu, quem não leu. Para o planejamento não bater com o do pessoal da tarde dividimos as linguagens. Eu acho que fica mais tranquilo para criança não fica tão repetitivo.

Como é que vocês se organizam para planejar as ações para o mesmo agrupamento. Existe um planejamento comum para o agrupamento?

A gente faz assim, no mesmo semanário tem um em cima do lado da folha manhã e ao mesmo lado tarde, então uma olha o semanário um o da outra. Ele é único, está no mesmo espaço, não é separado. Você olha e já vê o que foi feito na turma da manha e a turma da tarde, para não acontecer de ter atividades repetitivas.

Em que medida você e sua parceira de trabalho conseguem concretizar o que planejam para o período. E que dificuldades vocês encontram no desenvolvimento daquilo que vocês planejaram?

Nós costumamos fazer esse planejamento na segunda feira e na quinta feira a gente avalia o que da certo o que não deu o que nos vamos repensar, também com aquele livro da vida a gente já acostumou fazer atividades e registrar ali, foi bacana, a gente meio que faz isso toda semana, então ali naquele registro ele dá uma visibilidade.

\section{Vocês conseguem concretizar o que planejaram?}

Sim, na quinta-feira a gente avalia e já remaneja o que não deu o que não está dando certo, a gente acostumou, deu para fechar.

\section{Como é que são tratados os imprevistos no seu planejamento?}

A gente trata de forma tranquila, o que não passa para criança aquela agitação a gente prolonga as datas das atividades.

\section{Com é que vocês "as quatro" trocam informações?}

Pelo caderno de comunicação sempre, pelo livro da vida, e pela conversinha de troca de período, mais o que faltou esse ano com a greve foram às reuniões coletivas, quem não fez greve teve as reuniões pedagógicas em um dia normal e quem fez greve passou para o sábado, então, por exemplo, não tivemos nenhuma reunião que esse ano a gente fez com $\mathrm{O}$ e I coisa que antigamente a gente se encontrava e esse ano não nos encontramos. 


\section{Como é que vocês quatro trocam experiências de prática?}

Ocorre essa troca sim, o que a gente registra ali no livro da vida fica ali, porque na porta é muito rápido, ai às vezes também quando a gente começa o caderno de comunicação, quando é uma coisa que chama muita atenção, colocamos lá. Mas, acho que nós tínhamos que ter um entrosamento melhor nesse sentido de sentar, trocar de planejar junto, mas é difícil. Até mesmo para fazer o relatório, não tem esse espaço. 


\section{APÊNDICE F - Entrevista com a Professora I}

Gostaria que você se apresentasse falando seu nome, idade nível de formação e experiência profissional.

Meu nome é I, tenho 42 anos, fiz o magistério no CEFAM na Vila Gomes, e fiz o normal superior que a prefeitura proporcionou pra gente, já dei aulas para $1^{\circ}$ até o $4^{\circ}$ ano do ensino fundamental, e também para a Educação Infantil, jardim 1 e 2, crianças especiais no Cotolengo e na APAE, esse ano eu trabalhei com uma sala de ANEE na prefeitura de Cotia, dei aula no EJA 3 anos mais ou menos, estou aqui no CEI há 8 anos.

Queria que você falasse um pouco do seu dia a dia aqui no CEI, dizendo como ocorre a comunicação entre você e as gestoras (coordenadora e diretora) e entre você e as professoras do seu agrupamento.

Com a coordenadora, converso todos os dias no PEA, fora isso ela sobe na sala para conversar com a gente, sobre o projeto, sobre algum acontecimento que não dê para ela estar comunicando no PEA, e com a diretora e tranquilo também, ela passa algumas informações que são necessária . Com as colegas da manhã a gente se comunica mais por meio do caderno ou chegamos um pouquinho mais cedo. Elas nos falam se alguém se machucou se tem algum comunicado, algum bilhete que vai ser enviado ,é uma boa comunicação, porque eu sempre chego mais cedo e bilhete todos os dias pelo caderno.

Gostaria que você relatasse como você vê esses encontros de formação, dizendo se eles têm ou não impactos sobre as práticas e se eles permitem a troca de experiência entre as professoras e também se você tem alguma sugestão de mudança.

Sim, essa formação ajuda muito a gente, claro que a maioria dos temas trabalhados nós já conhecemos, mas dá para mudar bastante e a troca de ideia é muito importante, sempre estamos conversando com as colegas as práticas diárias que acontece na sala e é uma troca legal, eu acredito que muda bastante o trabalho da gente a questão da reflexão, você passa a refletir mais, “será o que eu estou fazendo é legal”? “Será que essa atividade eu preciso repetir?” Tudo com base de troca de ideia. 
O que você pensa sobre a organização dos tempos e dos espaços aqui da instituição como um todo?

É bem complicado, é bem corrido, a gente tem que tomar cuidado a todo instante para não trombar um com o outro, mesmo tendo planejando do espaço. Com essas mudanças de clima, às vezes você tem que mudar o que você planejou e tem professor que é flexível a essas mudanças, tem alguns que não, aí complica um pouco o espaço, mas a gente sempre resolve conversando, claro que tem umas discussões de vez em quando, mas dá pra levar sim.

\section{Como que é pensado o projeto político pedagógico da unidade?}

A gente leu ele, fez algumas mudanças, sempre quando é feito a gente procura reunir as ideias dos funcionários, professores, coordenador, diretor com todo mundo, sempre tentando melhorar as coisas que precisam em relação a escola mesmo.

\section{Vocês definem temáticas que vão ser tratadas?}

Sim, é bem elaborado.

Como o trabalho do agrupamento se relaciona com o projeto pedagógico, existe alguma relação entre o que vocês pensaram para desenvolver com o agrupamento e o que diz o projeto pedagógico?

Sim, eu acho que tem que ter uma relação, porque se a gente pensou junto a gente tenta fazer acontecer as coisas que a gente planejou.

Quais são os momentos da rotina que você considera mais marcantes no CEI e por quê?

Eu acho que tudo é importante todos os momentos da nossa rotina, mas eu acho que a questão da alimentação e da higiene da criança aprender, ter autonomia, se conhecer, conhecer os pertences dela, isso é muito importante nessa faixa etária, considero de suma importância primeiro a criança aprender cuidar dela, das coisas dela do amigo de si e do outro mesmo.

E como você considera esses momentos que você acha mais importantes no planejamento. Como eles são pensados no planejamento de vocês? 
Ele acontece de forma diária, tem que ser rotina mesmo, para eles aprenderem se concentrar, principalmente no inicio do ano, acho que acontece de forma bem batida mesmo, todos os dias na mesma tecla, observando a criança vai aprendendo de ver a gente falar, se repetir aquela cena aquela situação todos os dias ela vai ficando bem independente.

Como são consideradas as crianças no seu planejamento? Em que elementos você se apoia para planejar o trabalho?

A gente se apoia na devolutiva das crianças, elas têm que melhorar, elas podem dá mais, estão mais interessadas ou não.

\section{Em que você pensa em quando você vai planejar o seu trabalho?}

Oferecer o melhor de mim, o melhor do que eu posso, eu acho que a criança fica tanto tempo fora de casa, que ele se sinta bem que se sinta seguro com a gente no que está fazendo, que cresça mesmo.

\section{Como é que você consegue perceber a participação da criança e da família no} seu planejamento?

Muito, pela própria agenda a mãe mostra interesse em perguntar como foi o dia do filho se a gente está precisando de alguma coisa, ela participa de tudo que acontece em casa, eles começam a confiar na gente, a princípio não, então é um trabalho de aproximação é feito família e escola.

Você pode dar um exemplo de alguma participação da família no planejamento de vocês?

Sim, na biblioteca itinerante é bem visível a mãe que gosta, que faz questão que a criança leve toda sexta-feira, que lê com ele, que discuti, que sabe o titulo de todos os livros. A gente pergunta que livro é esse e ela já fala o nome o autor vai falando tudo, é uma coisa bem legal, porque eles são muito pequenos e pra você acreditar que isso vai acontecer é através de um trabalho mesmo. Agora a criança que a mãe diz não ter tempo, que não lê que não participa também a gente percebe na roda. A criança que não trás o livro de volta que a gente cobra a mãe e o pai e a própria criança fala: "eu não vou trazer minha mãe rasgou”. Em outras atividades que a gente faz, nas festas que acontece na escola a participação é interesse do pai em saber se a criança tem que vir 
vestida com algum tipo de roupa especial se vai ter alimentação, se vai ter apresentação, a questão de estar participando mesmo, tem família que não participa de nada não vista a agenda não liga na escola para falar se a criança chega com algum machucado, eu acho que o trabalho que a gente faz aqui a maioria das professoras e o registro de tudo que acontece no dia com a criança muito importante, a troca do professor, de escrever o que aconteceu, e os pais aqui aprendem também isso, a maioria esse ano manteve o número de telefone verdadeiro na agenda que você liga e vem de imediato buscar, mas isso é um trabalho que demora um tempo.

Com que o planejamento de vocês se relaciona com o planejamento das professoras do outro período?

A gente divide as linguagens, é uma coisa meio que separado, ao mesmo tempo é junto, nós sabemos tudo que elas estão fazendo, elas sabem o que a gente está fazendo, até mesmo um dia que tem vídeo pra elas e não tem vídeo pra nos, um filme que elas já passaram nós não vamos repetir, porque a gente sabe que foi feito o trabalho com aquele filme, nos comunicamos bem para não oferecer novamente a mesma coisa pra criança, por isso de dividir as linguagens, acho que para a criança não estar vendo todo dia a mesma coisa se repetindo.

Como vocês se organizam para planejar as ações para o mesmo grupo, existe um planejamento comum?

Como dividimos as linguagens a gente fez junto, cada linguagem a gente fez junto, mas na hora de trabalhar elas trabalharam separado, elas trabalharam as linguagens, mas para o planejamento é uma coisa só.

\section{Quando é feito esse planejamento?}

$\mathrm{Na}$ reunião pedagógica, sempre tem uma época que a coordenadora deixa a gente fazer, quando dá também para se reunir também, o que dificulta é o horário, só quando tem uma reunião que da para agrupar todas, mas sempre que dá a gente faz junto.

Em que medida você e sua parceira conseguem concretizar o que vocês planejaram e quais dificuldades que vocês encontram?

Não e sempre que dá para cumprir tudo que foi planejado, no começo eu e a $\mathrm{O}$ pensamos em dar uma acelerada, depois nos vimos que nessa faixa etária o que importa 
mesmo que vale a pena mesmo é qualidade não a quantidade do que a criança vai aprender, nos policiamos muito para as coisas acontecerem no tempo da sala quanto eles precisavam do tempo para conseguir do retorno do que a gente planejou.

\section{Como são tratados os imprevistos no planejamento de vocês?}

A gente retoma outro dia, como a questão do som que nos estávamos trabalhando com eles a pesquisa sonora teve muitos momentos que não cumprimos o que estava planejado mais sempre refletimos e retomamos .

\section{Como vocês trocam informações sobre os dois períodos?}

Por meio do caderno mesmo, mas sempre que dá a $\mathrm{O}$ chega mais cedo, sempre que dá, mas é mais pra mim mesmo que elas passam verbalmente, porque eu chego antes, as professoras da manhã são bem comunicativas e escrevem quando não dá para a gente se falar, deixam tudo anotado, deixam pen drive com fotos que a gente precisa, algumas coisas que a gente combina que não da tempo de uma dupla fazer a outra dupla faz, porque trabalhar com bastante pessoas é difícil, mas até que a gente foi bem.

\section{E experiência de prática entre vocês como que vocês trocam?}

Então quando conseguimos nos falar aqueles minutos tecemos comentários rápidos, ou deixamos por escrito. 


\section{APÊNDICE G - Registros de observação}

$04 / 09 / 2013$

Acolhida das crianças

\begin{tabular}{|l|l|}
\hline Data & 04/09/2013 (CEI Rio Pequeno) \\
\hline $\mathbf{N}^{\circ}$ registro & 01 \\
\hline Horário & 08h00min às 08h30min \\
\hline Pesquisadora: Lídia Godoi \\
\hline Professoras envolvidas: O e P. \\
\hline Turma: MGI-AB \\
\hline $\begin{array}{l}\text { Crianças presentes: Zé, Sarah, Sophia, Vivi, Ingrid, Yasmin, Henrique, Mateus, Marcos, } \\
\text { Vitor, Lara, Eduardo, Vinícius, Jeferson, Tiago, Luiz (total de } 16 \text { crianças). }\end{array}$ \\
\hline
\end{tabular}

\begin{tabular}{|l|l|}
\hline Natureza da atividade e materiais & $\begin{array}{l}\text { A acolhida é uma atividade permanente e faz } \\
\text { parte da rotina do CEI. }\end{array}$ \\
\hline $\begin{array}{l}\text { Participação das crianças e produções } \\
\text { coletivas e individuais }\end{array}$ & $\begin{array}{l}\text { As crianças, em sua grande maioria, mostraram- } \\
\text { se muito envolvidas em contar histórias umas às } \\
\text { outras. }\end{array}$ \\
\hline $\begin{array}{l}\text { Comunicação: Adulto-criança/ } \\
\text { criança-criança }\end{array}$ & $\begin{array}{l}\text { Adulto-criança: faltou à interação, talvez nesse } \\
\text { momento a professora não considerasse } \\
\text { importante sua intervenção. } \\
\text { Criança-criança: muito rica, as crianças } \\
\text { conversavam entre si o tempo todo. Contavam } \\
\text { muitas histórias umas para as outras. }\end{array}$ \\
\hline $\begin{array}{l}\text { Acontecimentos planejados e } \\
\text { imprevistos }\end{array}$ & $\begin{array}{l}\text { A acolhida foi planejada somente na questão da } \\
\text { organização do espaço. Não houve imprevistos. }\end{array}$ \\
\hline
\end{tabular}

\section{Relatório}

As professoras definem que enquanto $\mathrm{P}$ (que está substituindo a $\mathrm{M}$ durante uma licençasaúde) recebe as crianças no portão do corredor (piso superior), $\mathrm{P}$ fica na sala com quem for chegando.

A sala está organizada com tapetes de EVA pelo chão, colocados separadamente em grupos de quatro tapetes. Uma espécie de bolsão com livros infantis. Ele é transparente e então dá 
para ver todos os livros que estão expostos. A sala está organizada em áreas de interesse; essa organização é permanente. Mas as crianças só brincam nas áreas em momentos pontuais da rotina.

A acolhida é uma atividade permanente, faz parte da rotina da unidade. A professora A hoje organizou a acolhida na área de leitura. Distribuiu sobre os tapetes vários livros infantis dentro de uma caixa, de modo que as crianças podiam pegar o livro que quisessem.

Vivi é a primeira a chegar.

Ela escolhe um livro com imagens de golfinhos baleias, tubarões...

$P$ percebe ela folheando e olhando a imagem do tubarão. Abaixa e pergunta:

- Quem é esse? Baleia ou golfinho?

Ela responde prontamente:

- Gofio.

Sarah, Sofia, Ingrid e Eduardo estão reunidos. Cada um com um livrinho na mão. Sarah conta a história para o Eduardo, era o livro da Ninoca.

- Ola Eduado, ela tem boca, nariz, olho (mostrando as partes do corpo da Ninoca). Esse roxo aqui ó. Ela tem o nariz grande.

Eduardo escuta atento.

No canto perto do espelho, estão Zé e Vivi.

Vivi:

- Oia o tubarão Zé!!! Oia o tubarão aqui ó... ele faz susto. Arrrrrr (imita o tubarão)

Vivi me mostra o tubarão:

- Ó ele abe a boca. Mode, tem dente gandão. Olha o gofinho (ela me mostra virando a página).

Depois pega o livro da lagartixa, me mostra e diz:

- Ó a lagartixa, ela dome (dizia o que via na ilustração).

Perto de mim, Marcos e Sarah estão conversando. Ambos pegam o livro do cocoricó.

Marcos diz para Sarah:

- Os dois é igual, ó Sara ó (mostra o livro dele para Sarah).

Percebo uma rodinha formada por Zé, Jeferson, Yasmin e Lara. Jeferson é quem conta história para a turma. Ele está contando a história do Lobo e os Três Porquinhos. As crianças, atentas, escutam o amigo:

- O lobo tem uma casinha. E o lobo tá queimando o bumbum dele. "Ai socorro, socorro, meu bumbum tá queimado" (Jeferson usa entonação, faz a voz do lobo).

Vivi se aproxima de mim com um livro que tem imagens de gato e diz:

- Ó, isso é o gato. O gato mode eu!

Vivi dá uma voltinha e chega onde estamos eu, Jeferson, Zé, Yasmin, Lara e Marcos com um livro. Nele continha muitas imagens de tigres.

Vivi coloca o livro no colo do Jeferson que para, imediatamente, de contar a história do lobo:

- Ó Jefeson, to da onça (diz Vivi).

Ingrid:

- Que bicho é esse?

Jeferson: onça, onça, onça.

São 07h30min. P, que até agora conversava com $\mathrm{P}$ na mesa do professor, convida as crianças para guardarem o livro.

- Gente, agora vamos guardar os livrinhos.

Zé entrega o seu.

$\mathrm{P}:$

- Obrigada, Zé.

As crianças ajudam a guardar todos os livrinhos. 


\section{Algumas impressões}

As crianças se organizam muito bem sozinhas. Estiveram sempre organizadas em pequenos grupos. Todos estavam envolvidos com as histórias, contudo, só consegui acompanhar alguns grupos.

Para a turma, a leitura parece ser uma atividade muito prazerosa e frequente. É possível perceber isso pelo próprio tempo em que as crianças permanecem envolvidas na atividade. É uma prática entre as crianças contar histórias umas às outras. As professoras $\mathrm{P}$ e V trabalham um projeto chamado "Arca de Noé", que aborda os animais (todos). Percebi que ele está muito presente entre as crianças, não só pela produção oral, mas também porque os livros que traziam histórias com animais foram os mais utilizados na leitura. Sobretudo os peixes: livro da pequena sereia, das baleias etc.

Observei que não houve uma atenção mais focada por parte das professoras em relação às interações com as crianças nesse momento. Fiquei pensando que esses são momentos ricos para estabelecer relações e vínculos e também para que elas possam tomar conhecimento do que as crianças aprenderam, além de perceber as direções que podem ser tomadas a partir da observação da turma. Porém, às vezes não prestamos a devida atenção a isso. Talvez não por negligência, mas por outros fatores presentes no contexto em que se dá a ação que nos encaminham para outras direções.

Com certeza, teria sido mais rico com as interações entre adulto-criança. Porém, me pareceu haver, por parte das professoras, uma concepção de infância que valoriza a criança enquanto sujeito. Chego a essa conclusão pela própria preocupação com a organização do espaço para recebê-los. Sem dúvidas, há, em outros momentos, interações mais próximas entre as crianças e as professoras, pois, se esse espaço foi concebido desse modo tendo em vista as crianças, é porque possivelmente houve situações de observação do envolvimento dos pequenos em relação ao espaço.

\section{Brincadeiras livres no parque}

\begin{tabular}{|l|l|}
\hline Data & $04 / 09 / 2013$ \\
\hline $\mathbf{N}^{\mathbf{0}}$ registro & 02 \\
\hline Horário & 09h00min às 09h30min \\
\hline Pesquisadora: Lídia Godoi \\
\hline Professoras envolvidas: P e E. \\
\hline Turma: MGI-AB \\
\hline $\begin{array}{l}\text { Crianças presentes: Zé, Sarah, Sophia, Vivi, Ingrid, Yasmin, Henrique, Mateus, Marcos, } \\
\text { Vitor, Lara, Eduardo, Vinícius, Jeferson, Tiago, Luiz (total de 16 crianças). }\end{array}$ \\
\hline
\end{tabular}

\begin{tabular}{|l|l|}
\hline Natureza da atividade e materiais & $\begin{array}{l}\text { Atividade permanente: brincadeira livre no } \\
\text { parque. As crianças ficam livres para brincar } \\
\text { como quiserem no parque. }\end{array}$ \\
\hline $\begin{array}{l}\text { Participação das crianças e produções } \\
\text { coletivas e individuais }\end{array}$ & $\begin{array}{l}\text { As crianças brincam juntas no parque, todas } \\
\text { estão envolvidas em alguma atividade, andar de }\end{array}$ \\
\hline
\end{tabular}




\begin{tabular}{|l|l|}
\hline & $\begin{array}{l}\text { triciclo, brincar junto de faz de conta. } \\
\text { Movimentam-se livremente e brincam umas com } \\
\text { as outras, interagem com outras turmas, com } \\
\text { crianças de idades diferentes. }\end{array}$ \\
\hline $\begin{array}{l}\text { Comunicação: Adulto-criança / } \\
\text { criança-criança }\end{array}$ & $\begin{array}{l}\text { Adulto-criança: faltou a interação. Talvez nesse } \\
\text { momento a professora não a julgasse importante. } \\
\text { Criança-criança: muito rica, as crianças } \\
\text { conversam entre si o tempo todo. Criam } \\
\text { brincadeiras e se organizam sozinhas através do } \\
\text { diálogo. }\end{array}$ \\
\hline $\begin{array}{l}\text { Acontecimentos planejados e } \\
\text { imprevistos }\end{array}$ & $\begin{array}{l}\text { No parque, os acontecimentos não são } \\
\text { planejados. Tudo ocorreu de forma espontânea. }\end{array}$ \\
\hline
\end{tabular}

\section{Relatório}

No parque, estão as duas turmas de MG e as duas de berçário. As professoras resolveram todas descer com as crianças para organizar a atividade com as salas ambientes.

Chego ao parque e já me chama a atenção um grupo de crianças brincando.

Há, no canto do parque, na área coberta, perto da grade que dá para o estacionamento, duas mesas. Mesas como as que as crianças usam para se alimentar no refeitório. Embaixo dessas mesas estavam: Ingrid, Sofia, Jeferson, Yasmin, Lara e Vinícius. Aproximo-me e pergunto do que estão brincando, já supondo que aquilo era uma brincadeira.

Ingrid responde:

- De ícone, iconde.

Nesse momento, Matheus se aproxima e finge ser um lobo.

- Arrrr, vou pegar!

Vivi cantava:

- Lobo não me pega, lobo não me pegaaa.

As crianças tinham organizado sozinhas uma brincadeira, com regras, em que os que estavam debaixo da mesa escondiam-se e Matheus, o lobo, deveria pegá-los (incrível)

Pergunto à Ingrid:

- De quem vocês estão se escondendo? (só para ver o que ela respondia)

Ingrid:

- Tamoicondendo do Matheus Nogueira. Ele é o lobo (eles estão desempenhando outro papel, e ela sabe disso).

- Olha o cavalo! (diz Sarah, ao se aproximar o Matheus de triciclo).

Marcos se afasta. Agora Vivi é o lobo. Ela faz ruídos e finge que vai pegar os que estão debaixo da mesa.

Pergunto:

- Vivi quem você é? Ela responde:

- Eu sou Viviane.

Matheus sobe na mesa para brincar de pegar as crianças.

Matheus e Sarah voltam. Agora brincam de esconde: Marcos, Sarah, Matheus, Yasmin, Ingrid, Vivi, Eduardo, Jeferson, Lara, Vinícius, Luiz, Henrique e Anita. Quase a turma toda. Marcos se aproxima da mesa onde as crianças se escondem:

- Agora eu sou o lobo... Arrrrr...

As crianças gritam:

- Socorro, socorro. 
A brincadeira organizada pelas crianças, que já durou cerca de 30 minutos, acaba. E foi interrompida para que elas pudessem entrar e tomar o suco.

\section{Salas ambientes}

\begin{tabular}{|l|l|}
\hline Data & $04 / 09 / 2013$ \\
\hline $\mathbf{N}^{\mathbf{0}}$ registro & 03 \\
\hline Horário & $9 \mathrm{~h} 40 \mathrm{~min}$ às 10h30min \\
\hline Pesquisadora: Lídia Godoi \\
\hline Professoras envolvidas: P, E, V, E, O, ED, N, F e V. \\
\hline Turma: MGs e BII \\
\hline $\begin{array}{l}\text { Crianças presentes: Zé, Sarah, Sophia, Vivi, Ingrid, Yasmin, Henrique, Mateus, Marcos, } \\
\text { Vitor, Lara, Eduardo, Vinícius, Jeferson, Tiago, Luiz (total de 16 crianças). }\end{array}$ \\
\hline
\end{tabular}

\begin{tabular}{|l|l|}
\hline Natureza da atividade e materiais & $\begin{array}{l}\text { Atividade permanente que acontece uma vez na } \\
\text { semana, sempre às quartas-feiras, com a } \\
\text { intenção de que as crianças possam escolher o } \\
\text { que fazer em contato com diferentes áreas de } \\
\text { interesse, organizadas a critério do professor } \\
\text { responsável por cada área. }\end{array}$ \\
\hline $\begin{array}{l}\text { Participação das crianças e produções } \\
\text { coletivas e individuais }\end{array}$ & $\begin{array}{l}\text { Total. Parecem se divertir bastante. Circulam } \\
\text { pelas áreas constantemente. }\end{array}$ \\
\hline $\begin{array}{l}\text { Comunicação: Adulto-criança / } \\
\text { criança-criança }\end{array}$ & $\begin{array}{l}\text { Adulto-criança: ótima, as professoras } \\
\text { acompanham as crianças que estão na sala, dão } \\
\text { suporte para suas brincadeiras, elogiam, } \\
\text { encorajam. } \\
\text { Criança-criança: muito boa, as crianças têm mais } \\
\text { uma oportunidade de brincarem juntas, } \\
\text { conversam e circulam pelas salas em pequenos } \\
\text { grupos. }\end{array}$ \\
\hline $\begin{array}{l}\text { Acontecimentos planejados e } \\
\text { imprevistos }\end{array}$ & $\begin{array}{l}\text { Não houve imprevistos. Tudo ocorreu de forma } \\
\text { bem planejada e articulada, cada um apresentava } \\
\text { uma proposta diferente. }\end{array}$ \\
\hline
\end{tabular}

\section{Relatório}

As professoras dos MGs e berçários II (piso superior), desde o início do ano, uma vez por semana, organizam salas ambientes, para que as crianças circulem entre as áreas de interesse que desejarem e escolham no que fazer. Cada professora decide o que vai fazer um dia antes.

Hoje, havia: área da fantasia, sombras e lanternas, casinha, jogos e brinquedos.

A sala da fantasia era a lilás: havia várias fantasias de super-heróis, princesas, animais, personagens de TV (como o Chaves, por exemplo). Prof. Resp. V, E e O. 
Na sala amarela, a sala de jogos e brinquedos, havia: bonecos diversos, jogos psicomotores, monta-monta de florzinha. Prof. Resp. P e E.

Na sala verde, há sombras e lanternas: a sala foi organizada com tecidos de malha, formando um grande labirinto, e algumas lanternas. Prof. Resp. F e V.

A sala rosa é a da casinha: algumas panelinhas sobre um fogão, e a lanchonete com sorvete, bolo etc. (poucas opções, na verdade). Prof. Resp. ED e N.

No corredor, estão todas as turmas reunidas. As professoras apresentam as salas.

$\mathrm{AC}$ :

- Aqui na sala amarela tem jogos, amarelinha e bonecos. Vocês podem escolher. F:

- A sala verde tem sombras e lanternas.

$\mathrm{V}$ :

- Aqui na lilás tem fantasia de todo tipo.

AC:

- E lá na sala rosa tem casinha.

- Podem brincar (diz V)

Vai ficar difícil acompanhar toda a turminha, mas vou tentar passar em todas as salas e acompanhar as crianças do MGI-AB que estejam brincando nas salas.

Começo na sala de jogos e brinquedos.

Henrique, Vitor, Yasmin e Tiago estão brincando juntos no tapete em que estão os brinquedos pequenos (bonecos etc).

Vitor pega dois bonecos do Shrek e diz:

- Olha. São irmãos.

Começa a fazer um diálogo entre os dois Shreks:

- Oi Shrek, tudo bem?

- Tudo bem e você. Você tá bem?

Henrique se aproxima e pede um boneco. Vitor dá e eles começam a brincar juntos de lutinha de Shrek.

Vou até a sala de fantasia.

Encontro às professoras colocando as fantasias nas crianças. Estavam lá as professoras $\mathrm{P}$, $\mathrm{V}, \mathrm{O}$ e $\mathrm{E}$.

Sento-me próximo à $\mathrm{P}$.

Henrique se aproxima dela e pede uma fantasia.

$P$ responde:

- Vem, vamos escolher uma para você.

P leva Henrique até as fantasias e ele escolhe uma do Chaves. Ela coloca no Henrique o chapéu e pede para que ele vá até o espelho ver se gosta.

Henrique vai ao espelho e volta com um sorriso no rosto.

P:

- Gostou? Então vem colocar o resto.

$\mathrm{P}$ coloca o resto da boca e diz:

- Você ficou lindo, Henrique!!!

Vou até a sala de lanternas e sombras.

Lá encontro Sarah, Ingrid, e Matheus brincando debaixo da mesa. Zé, e Sophia estão sobre a mesa com suas lanternas.

Aproximo-me e sento próximo a eles.

Sarah aponta a lanterna em uma direção qualquer e diz:

- Olha! Uma aranha!

Marcos grita:

- Ai... 
Sarah:

- Gente!

Ingrid:

- Que foi Sarah?

Sarah:

- Temos que tomar banho...

Eles saem de debaixo da mesa e fingem tomar banho. Cada um com sua lanterna na mão. Enquanto isso, Zé e Sophia apontam suas lanternas para todos os cantos, mas continuam em cima da mesa.

Marcos, Sarah e Ingrid terminam o banho e voltam para debaixo da mesa.

Ingrid:

- Vamos dormir. Apaga a luz.

Ingrid diz:

- Pai, quem construiu essa casa?

Marcos:

- Foi eu, filinha.

Ingrid olha para mim e diz:

- Ele é o pai, a Sarah é mãe e eu sou filhinha.

Escuto a professora $\mathrm{F}$, responsável pela sala, chamar as crianças:

- Vem gente, vem ver a barata.

Sarah, Marcos e Ingrid, parecem não ouvir e continuam brincando.

Matheus:

- Apaga a luz. Vamos dormir (as lanternas são usadas não com o objetivo que a professora pensou que era fazer sombras. Eles reinventaram, criaram uma outra função para a lanterna.

Ela era a lâmpada da casa).

Ingrid:

- Anda gente, vamos acordar.

A professora $\mathrm{V}$, que também era responsável pela sala, chama a atenção das crianças:

- Gente, vem ver a bruxa!

V faz a sombra com chapéu da bruxa.

Sarah, Marcos e Ingrid continuam brincando embaixo da mesa.

Ingrid:

- Tá na hora de tomar café.

Sarah:

- Vamos dormir.

Os três de deitam e iluminam o tampo da mesa com as lanternas.

Ingrid se cansa da brincadeira e diz:

- Vamos pra outra sala, Sarah.

As duas saem da brincadeira, Marcos sai junto.

Passo na sala rosa, da casinha. Lá, estão somente suas crianças do próprio agrupamento.

Panelinhas pelo chão. As duas crianças brincam na lanchonete.

\section{Pesquisa sonora}

\begin{tabular}{|l|l|}
\hline Data & $04 / 09 / 2013$ \\
\hline $\mathbf{N}^{\mathbf{0}}$ registro & 04 \\
\hline Horário & $14 \mathrm{~h} 50 \mathrm{~min}$ às $15 \mathrm{~h} 40 \mathrm{~min}$ \\
\hline
\end{tabular}




\begin{tabular}{|l|}
\hline Pesquisadora: Lídia Godoi \\
\hline Professoras envolvidas: O e I. \\
\hline Turma: MGI-AB \\
\hline $\begin{array}{l}\text { Crianças presentes: Zé, Sarah, Sophia, Vivi, Ingrid, Yasmin, Henrique, Mateus, Marcos, } \\
\text { Vitor, Lara, Eduardo, Vinícius, Jeferson, Tiago, Luiz (total de } 16 \text { crianças). }\end{array}$ \\
\hline
\end{tabular}

\begin{tabular}{|l|l|}
\hline Natureza da atividade e materiais & $\begin{array}{l}\text { Sequência de atividade realizada todas as } \\
\text { quartas-feiras envolvendo a pesquisa sonora. } \\
\text { (Atividade dirigida). Os materiais utilizados } \\
\text { foram: rádio, CDs, canetinhas, giz de cera. A } \\
\text { intenção era que as crianças pudessem perceber } \\
\text { as diferenças rítmicas e as registrassem no papel. }\end{array}$ \\
\hline $\begin{array}{l}\text { Participação das crianças e produções } \\
\text { coletivas e individuais }\end{array}$ & Todas as crianças participaram. \\
\hline $\begin{array}{l}\text { Comunicação: Adulto-criança / } \\
\text { criança-criança }\end{array}$ & $\begin{array}{l}\text { Houve pouca comunicação entre as crianças, } \\
\text { acredito que por ser uma "atividade dirigida". }\end{array}$ \\
\hline $\begin{array}{l}\text { Acontecimentos planejados e } \\
\text { imprevistos }\end{array}$ & $\begin{array}{l}\text { O planejado: as crianças deveriam escutar a } \\
\text { música e ao mesmo produzir marcas. } \\
\text { Imprevisto: algumas crianças preferiram brincar } \\
\text { com os materiais: Ex.: canetinhas que viram } \\
\text { aviões e torres. }\end{array}$ \\
\hline
\end{tabular}

\section{Relatório}

As crianças voltam para a sala depois de tomarem o leite. A professora $\mathrm{O}$ está terminando de organizar a sala para a atividade.

Andréa:

- Gente, senta na beiradinha do tapete. Vocês sabem o que a gente vai fazer agora?

Matheus responde:

- Atividade!

I:

- Que atividade?

Ninguém responde.

I fala com ar de frustração.

-Nossa, eu expliquei mal. Explica de novo aí, O.

A entra na roda em que as crianças estão esperando sentadas e diz:

- É assim. Aqui tem papel e a $O$ vai dar canetinha. Vou colocar a música e vocês vão desenhar como vocês sentirem. Quando a música parar, tem que parar de desenhar.

A termina de cobrir o espelho da sala com papel craft para que as crianças possam desenhar.

$\mathrm{O}$ :

- Pode pegar a canetinha, mas não pode desenhar ainda, espera eu terminar de colocar o papel. 
As crianças não querem esperar. Querem colocar logo.

$\mathrm{R}$ :

- Espera, gente. Tem que ouvir a música primeiro.

$\mathrm{O}$ vai em direção ao rádio e pergunta para as crianças.

- Quando não tem som como que a gente chama?

$\mathrm{O}$ :

- Chama silêncio.

O coloca a música. É um ritmo caribenho.

As crianças começam a desenhar. O desenha junto.

Lara faz pontinhos rapidinhos.

Sarah faz pequenos risquinhos.

O:

- Ó, presta atenção na música.

I desenha árvores no outro lado do papel árvores e nuvens.

Troca a música (agora é uma música oriental)

Matheus desliza devagar a canetinha no papel.

A música para.

Jeferson diz:

- Parou, parou...

Agora é uma música africana.

Percebo que Eduardo, Ingrid, Vinícius preferem brincar na mesa em que estão as canetinhas. Eduardo faz uma torre com as tampas.

I percebe também e vai até lá e diz:

- Vinícius, vamos desenhar (tomando a torre da mão do Eduardo).

A turminha vai desenhar.

Vinícius pouco se envolve. O que ele quer mesmo e brincar que a canetinha transforma-se em avião.

Vitor aproxima-se da mesa para pegar uma canetinha.

I:

- Pega um e vai desenhar Vitor.

São $15 \mathrm{~h} 15 \mathrm{~min}$.

I pede às crianças que guardem as canetinhas. E diz:

- Agora a gente vai fazer outra coisa. Vamos dançar.

O coloca a mesma música caribenha da primeira parte da experiência e começa a dançar, formando uma roda.

Marcos não quer dançar como a turma. Prefere apoiar as mãos no chão e colocar os pés para cima um de cada vez. O percebe e diz:

- O Marcos vai se retirar da atividade, ele não está se controlando (coloca o Marcos sentado no colchão perto do armário da sala).

Sozinhas ao som da música, pé com pé, um ritmo mais agitado, as crianças pulam.

A pergunta:

- Essa música é mais rápida.

As crianças em coro respondem que é.

A troca o ritmo. Agora é um ritmo oriental.

Ingrid, Matheus, Yasmin, Vitor, Eduardo, Marcos e Jeferson imitam cachorro e andam pela sala.

O chama a atenção:

- Todo mundo para o tapete!

Sofia faz no outro canto da sala, um movimento de pular e bater palmas.

O: 
- Olha só, gente. Olha o que a Sofia está fazendo. Vamos imitar ela?

As crianças começam a pular como a Sofia.

São $15 \mathrm{~h} 35 \mathrm{~min}$ Esse é o $3^{\circ}$ momento da experiência.

$\mathrm{O}$ desliga o som e pede que as crianças sentem-se na beirada do tapete.

Em roda, O pergunta para as crianças:

- E aí, gente, ficaram bons os desenhos?

Sarah responde:

- Eu rabisquei aqui tanto com canetinha rosa.

Matheus:

- Eu brinquei de piscina na casa da Gigi.

O:

- As músicas que a gente escutou eram fortes ou fracas?

Sarah responde:

- Olha, tinha forte, fraco, curto e longo.

Qual a música que era forte? A pergunta.

Sarah:

- Dança cudulo, tinha forte (essa era a musica de ritmo caribenho).

Marcos:

- Eu gostei de desenhar, dançar e pular.

$\mathrm{O}$ :

- Dá para desenhar e pular junto?

Vitor:

- Dá sim.

Luiz:

- Não

$\mathrm{O}$ :

- Querem fazer um teste para ver se dá? Então vai lá: Vinícius, Sarah, Yasmin, Vitor, Ingrid, Luiz, peguem as canetinhas para desenhar.

I:

- Agora vamos ver quem consegue desenhar e dançar ao mesmo tempo.

Ingrid, Sarah e Vitor dançam desenhando no ritmo da música.

Agora é a vez de Eduardo, Matheus, Sophia, Lara, Zé, Jeferson e Tiago.

Eduardo desenha e dança no ritmo da música. Mas isso não parece lhe interessar. Ele vai até a mesa em que estão as canetinhas e começa de novo construir a torre com as tampas.

I, ao perceber:

- Eduardo, vai pra lá desenhar.

O, ao perceber o Marcos, pulando pela sala:

- Marcos, você não vai querer? Senta aqui. E coloca-o novamente sentado no colchão perto do armário.

$\mathrm{O}$ :

- Agora vamos guardar as canetinhas. Vamos conversar de novo.

Já em roda, O pergunta:

- E aí, dá para dançar e desenhar?

Vitor:

- Eu desenhei e dancei.

$\mathrm{O}$ :

- E quando a música é forte a gente desenha como?

Eduardo:

- Rápido.

$\mathrm{O}$ : 
- E se a música é fraca?

Vivi:

- Desenha devagazinho.

$\mathrm{O}$ :

- A gente vai colocar o desenho de vocês lá fora para o papai e a mamãe ver. Vocês vão explicar para o papai e a mamãe o que vocês fizeram.

\section{Impressões gerais}

\section{4/09/2013 - IMPRESSÕES GERAIS - MANHÃ}

Achei muito interessante a organização das brincadeiras pelas crianças. Isso revela o quanto a riqueza de experiências que elas vivenciam ganha significado em suas brincadeiras. Para além do faz de conta, as crianças se envolvem num jogo teatral, com personagens e regras definidas. Ou seja, eu sou a Viviane, mas agora represento um lobo. Os conflitos durante as brincadeiras são mínimos, dificilmente as crianças se agridem ou recusam-se a dividir os brinquedos. Penso que isso é fruto de práticas planejadas e sistemáticas cujo foco é a criança. Como os cantinhos, a leitura, os projetos trabalhados etc.

04/09/2013 - IMPRESSÕES GERAIS - TARDE

Notei organização na hora de preparar o espaço. As professoras já haviam separado os materiais que iriam utilizar. Só não arrumaram a sala antes porque as crianças estavam dormindo, então tiveram que se dividir para fazer esse trabalho. Esse é um fator específico na rotina do CEI. As próprias professoras têm de criar meios e estratégias para organizar os espaços em que vão acontecer as atividades. Uma parte da organização foi feita quando as crianças já estavam de volta na sala. Não há o hábito de envolver as crianças na organização das atividades, talvez fazer isso poderia reduzir o tempo de espera das crianças.

Num primeiro momento, percebi que estava tudo planejado para que as crianças desenhassem ao som de ritmos diferentes. Só que tudo aconteceu muito rápido, então me pareceu que as partes seguintes da experiência foram pensadas na hora em que ela acontecia. As professoras foram desdobrando outras experiências de acordo com o que percebiam de devolutiva das crianças.

Percebi que as professoras, ao pensar a atividade, levaram em consideração fatores importantes entre eles, havendo preocupação de apresentar sons característicos de diferentes culturas: afro, oriental etc. Isso mostra que, ao pensar as experiências, existe um estudo e uma intencionalidade das professoras, e o mais importante: que as experiências são pensadas.

Os objetivos e a intencionalidade por trás das experiências estavam claros. Contudo, o ímpeto de que todas as crianças fizessem o que estava sendo sugerido mostra a necessidade que o adulto tem de controlar cada movimento, um legado cultural da pedagogia tradicional que ainda está bem presente na prática. Esse ímpeto de manter o controle torna-se estressante tanto para o adulto como para a criança.

\section{$13 / 09 / 2013$}

\section{Acolhida das crianças}




\begin{tabular}{|l|l|}
\hline Data & $13 / 09 / 2013$ \\
\hline $\mathbf{N}^{\mathbf{o}}$ registro & 01 \\
\hline Horário & $08 \mathrm{~h} 00 \mathrm{~min}$ às 08h30min \\
\hline Pesquisadora: Lídia Godoi \\
\hline Professoras envolvidas: P e V. \\
\hline Turma: MGI-AB \\
\hline $\begin{array}{l}\text { Crianças presentes: Mathias, Thiago, Vinícius, Matheus, Yasmin, Henrique, Giovana, } \\
\text { Sarah, José, Duda, Dhara, Vinícius, Ingrid, Eduardo, Luiz, Jeferson, Lara, Marcos, Vitor, } \\
\text { Willian (total de 21 crianças). }\end{array}$ \\
\hline
\end{tabular}

\begin{tabular}{|l|l|}
\hline Natureza da atividade e materiais & Acolhida. Atividade permanente. \\
\hline $\begin{array}{l}\text { Participação das crianças e produções } \\
\text { coletivas e individuais }\end{array}$ & Todas as crianças participam. \\
\hline $\begin{array}{l}\text { Comunicação: Adulto-criança / } \\
\text { criança-criança }\end{array}$ & $\begin{array}{l}\text { Adulto-criança: não há durante a brincadeira; } \\
\text { por outro lado, é constante durante a recepção } \\
\text { das crianças. } \\
\text { Criança-criança: as crianças brincam juntas e } \\
\text { conversam entre si. }\end{array}$ \\
\hline $\begin{array}{l}\text { Acontecimentos planejados e } \\
\text { imprevistos }\end{array}$ & $\begin{array}{l}\text { O espaço foi planejado para receber as crianças, } \\
\text { proporcionando-lhes escolhas. Não houve } \\
\text { imprevistos. }\end{array}$ \\
\hline
\end{tabular}

\section{Relatório}

A professora $\mathrm{V}$ disponibilizou, na área da leitura, em cima dos tapetes e próximo ao espelho, um jogo de encaixe. Assim, as crianças que chegassem poderiam escolher trabalhar com os livros na área da leitura ou com as peças. $\mathrm{P}$ ficou encarregada de receber as crianças na porta enquanto $\mathrm{M}$ recebia-os na sala.

Chegam primeiro Vinícius, Sarah, Zé e Mathias. V os recebe com um bom-dia.

Dizendo:

- Pessoal, vai tirando os cadernos da mochila e depois guardem. Estacionem as malas uma ao lado da outra.

As crianças tiram sozinhas as agendas e, em seguida, guardam as mochilas dentro do armário da sala, na parte de baixo destinada a esse fim.

V os informa:

- Olha, hoje a V colocou joguinho de encaixe. Pode pegar livrinho ou brincar com o jogo.

Enquanto $\mathrm{V}$ continua a receber e orientar as crianças que chegam, sento-me com as crianças na área em que estão trabalhando.

Ao me sentar, Mathias já vem me mostrar sua produção.

- Ó Lídia, eu tô fazendo um carro.

Sarah também que me mostrar sua produção:

- Eu tô fazendo um microfone para cantar. 
Ao meu lado, Vitor está envolvido folheando um livrinho. O livro se chama "Fada luz do sol".

No outro lado, está Mathias. Ele construiu uma arma. Começou a atirar:

- Pou, pou, pou.

A professora $\mathrm{V}$ interfere:

- Não, não, Mathias. Pô, Pô, não.

Percebo Sarah bem envolvida com o livro dos carros na mão e me aproximo.

Ela narra a história:

- Era uma vez um carro que tinha roda gigante e aí depois tinha roda, tinha amigo e tinha roda pequena.

Ingrid interrompe e diz:

- Conta pra mim!

Percebo que V recebe as crianças com palavra de atenção e carinho. Henrique chega:

- Bom dia! Tudo bem? Pode guardar a mochila tá. Posso te ajudar a tirar a blusa?(diz V)

Aos poucos todas as crianças vão chegando.

Percebo que cada pequeno grupo está envolvido em uma atividade.

Jeferson, Vitor, Sarah e Duda estão envolvidos com os livros contando histórias uns aos outros.

Ingrid e Vivi cantam com o microfone que construíram em frente ao espelho. E a música é "o que tem na sopa do neném"? (Palavra cantada)

Tiago, Eduardo e Zé brincam de polícia com as armas que construíram utilizando o jogo de encaixe.

O resto da turma está em volta do jogo de encaixe construindo seus objetos.

Após todos chegarem, a professora $\mathrm{V}$ avisa:

- Turminha, deixa a V falar uma coisa. Hoje a gente vai ter um monte de coisa, então já que já chegou todo mundo. Vamos guardar.

P:

- Vamos ajudar pessoal. Peraí, quero saber por que a Ingrid não está ajudando o Marcos a guardar?

$\mathrm{V}$ :

- Mathias, você não está ajudando a guardar?

AC:

- O Mathias, o Zé e o Eduardo não estão ajudando a guardar. Nossa! Muito bem! A Dhara tá ajudando!

Percebo a maior parte da turma empenhada em organizar o espaço em que brincaram.

\section{Projeto entorno}

\begin{tabular}{|l|l|}
\hline Data & $13 / 09 / 2013$ \\
\hline $\mathbf{N}^{\mathbf{o}}$ registro & 02 \\
\hline Horário & $09 \mathrm{~h} 47 \mathrm{~min}$ às $10 \mathrm{~h} 15 \mathrm{~min}$ \\
\hline Pesquisadora: Lídia Godoi \\
\hline Professoras envolvidas: $\mathrm{P}$ \\
\hline Turma: MGI-AB \\
\hline Crianças presentes:Marcos, Ingrid, Vitor e Dhara. \\
\hline
\end{tabular}




\begin{tabular}{|l|l|}
\hline Natureza da atividade e materiais & $\begin{array}{l}\text { Projeto entorno. Atividade permanente que } \\
\text { acontece duas vezes ao mês, sendo uma pela } \\
\text { manhã e outra à tarde. }\end{array}$ \\
\hline $\begin{array}{l}\text { Participação das crianças e produções } \\
\text { coletivas e individuais }\end{array}$ & Todas participaram. \\
\hline $\begin{array}{l}\text { Comunicação: Adulto-criança / } \\
\text { criança-criança }\end{array}$ & $\begin{array}{l}\text { Adulto-criança: a interação adulto-criança ocorre } \\
\text { através do contar histórias. As crianças forma } \\
\text { convidadas a participar e interagir com a história } \\
\text { contada. } \\
\text { Criança-criança: as crianças conversam mais } \\
\text { com as professoras e menos entre si nesse } \\
\text { momento. }\end{array}$ \\
\hline $\begin{array}{l}\text { Acontecimentos planejados e } \\
\text { imprevistos }\end{array}$ & $\begin{array}{l}\text { Tudo ocorreu de forma planejada. O único } \\
\text { imprevisto foi o fato das crianças pedirem para } \\
\text { ouvir a história mais uma vez. }\end{array}$ \\
\hline
\end{tabular}

\section{Relatório}

Ao subir do parque para sala, após o suco, as professoras $\mathrm{P}$ e Vpediram para que as crianças se sentassem no banco que fica na lateral do corredor, para que pudessem ser distribuídas pelas salas. V conduz cada turma de criança à sala que escolheram no dia anterior. Com as crianças acomodadas, $\mathrm{P}$ se dirige para a sala em que vai contar a história do grande monstro verde. Eu a acompanho. Lá estarão quatro crianças da turma. Ingrid, Vitor, Marcos e Dhara. Escolhi ficar lá, para acompanhar a $\mathrm{P}$ e o grupo de crianças da turma. Pois, com cada grupo em uma sala, tive que optar por ficar em um só espaço.

P prepara a sala, fechando as janelas para escurecer um pouco o ambiente.

As crianças estão em uma área em cima dos tapetes. Sento-me próximo a Vitor, Marcos e Ingrid. Dhara está um pouquinho mais afastada.

P está sentada em uma cadeira de frente para o grupo de crianças.

- Oi, turminha. Vocês escolheram a história do monstro. Todo mundo que tá aqui escolheu a história do monstro.

P mostra o livro. Em seguida, pergunta:

- Vocês tem medo de monstro?

Ingrid responde:

- Eu não tenho medo não!

P:

- Vamos primeiro olhar o livro. P mostra a capa, fala o nome da editora e do autor.

$\mathrm{P}$ lê a resenha. Ingrid, Marcos e Vitor nem piscam.

O livro é bem colorido, tem capa dura. A imagem do monstro aparece na capa com uma cor metálica e brilhante que chama a atenção.

$P$ pergunta:

- Vocês acham que o monstro morde?

Marcos responde:

- O monstomode.

P:

- Vamos ver. Começa a contar a história.

O livro é mesmo uma brincadeira gostosa, que envolve as crianças e traz de forma 
descontraída e divertida a figura do monstro com a intenção de descontruir o medo dessa personagem.

Durante a história, as imagens vão aparecendo. Aparece primeiro o olho do monstro, depois, as orelhas, o nariz, o cabelo os dentes e o rosto. Depois, todas essas partes vão desaparecendo à medida que as páginas são trocadas. E em cada página, manda-se ir embora uma parte do corpo do monstro.

P:

- Vamos mandar o cabelo dele ir embora? Então, vamos lá todo mundo. Vai embora grande cabelo espetado! (As crianças repetem em coro).

P:

- Agora vamos mandar embora os dentes. Vão embora grandes dentes afiados!

As crianças repetem.

Vitor repete imitando os gestos da $\mathrm{P}$.

Por último:

P:

- Agora vamos mandar o monstro todinho ir embora. Vai embora grande monstro verde!

AC:

- Agora só vai aparecer de novo quando vocês mandarem.

As crianças pedem de novo.

Na porta aparece a professora D. e diz:

- P, não dá mais tempo, as outras professoras já estão terminando.

$P$ fala para as crianças:

- Ah. Só vai dar para mostrar as imagens. Ela mostra o monstro e pergunta:

- Será que esse monstro morde?

Marcos:

- Morde sim!

$\mathrm{P:}$

- Eu não sei se ele morde, mas que ele tem dente afiado tem.

$P:$

- Gente, agora acabou a história, na outra semana tem mais.

\section{Projeto entorno (roda de conversa)}

\begin{tabular}{|l|l|}
\hline Data & $13 / 09 / 2013$ \\
\hline $\mathbf{N}^{\mathbf{0}}$ registro & 03 \\
\hline Horário & $10 \mathrm{~h} 25 \mathrm{~min}$ às $10 \mathrm{~h} 35 \mathrm{~min}$ (Sala ambiente) \\
\hline Pesquisadora: Lídia Godoi \\
\hline Professoras envolvidas: P e V. \\
\hline Turma: MGI-AB \\
\hline $\begin{array}{l}\text { Crianças presentes: Mathias, Thiago, Vinícius, Matheus, Yasmin, Henrique, Giovana, } \\
\text { Sarah, José, Duda, Dhara, Vinícius, Ingrid, Eduardo, Luiz, Jeferson, Lara, Marcos, Vitor, } \\
\text { Willian (total de 21 crianças). }\end{array}$ \\
\hline
\end{tabular}




\begin{tabular}{|l|l|}
\hline Natureza da atividade e materiais & Atividade dirigida após a escuta das histórias. \\
\hline $\begin{array}{l}\text { Participação das crianças e produções } \\
\text { coletivas e individuais }\end{array}$ & Boa parte das crianças participou. \\
\hline $\begin{array}{l}\text { Comunicação: Adulto-criança / } \\
\text { criança-criança }\end{array}$ & $\begin{array}{l}\text { Adulto-criança: a interação adulto-criança ocorre } \\
\text { através do diálogo com as professoras a respeito } \\
\text { das histórias ouvidas pelas crianças. } \\
\text { Criança-criança: as crianças conversam mais } \\
\text { com as professoras e menos entre si nesse } \\
\text { momento. }\end{array}$ \\
\hline $\begin{array}{l}\text { Acontecimentos planejados e } \\
\text { imprevistos }\end{array}$ & Tudo ocorreu de forma planejada. \\
\hline
\end{tabular}

\section{Relatório}

Após o término das histórias, as crianças voltam para a sala. $\mathrm{V}$ os convida a sentar:

- Turminha, agora vai sentar aqui no tapete. V continua: À tarde, vocês já fizeram isso de ouvir história em outra sala. Agora, a gente fez de manhã. Então, vamos contar para os colegas sobre as histórias que ouvimos. M pega um caderno para fazer anotações. $\mathrm{V}$ :

- Yasmin, qual a história que você foi?

Yasmin:

- Da vaca.

$\mathrm{P:}$

- E a Duda?

Duda:

- Eu fui ahistolia do lobo e o lobo bata no cavalo.

P:

- O que você gostou na história?

Duda:

- Eu gotei do cavalo.

P:

- E você, Thiago?

Thiago responde:

- Eu gotei da vaca.

$\mathrm{V}$ :

- E a Dharafoi em qual história?

Dhara:

- Do monsto.

$\mathrm{V}$ :

- Que história você escutou Eduardo?

Eduardo não fala, somente faz gestos com a mão.

$\mathrm{V}$ :

- E você, Marcos?

Marcos:

- É, é...

$\mathrm{P:}$

- Nossa você não sabe? Mas você até falou que o monstro morde! 
E você Sarah:

- Fui do uso polar. Olia, a coluja e o uso polar tinha uma supesa pra mamãe.

$\mathrm{P}$ fala para V:

- Nossa, mas o que tá acontecendo? Eles são tão falantes!

Noto um ar de preocupação das professoras pelo fato de algumas crianças não quererem participar.

$\mathrm{V}$ :

- E você, Mathias, qual história escutou?

Mathias:

- Foi do uso polar. O uso polar molava numa cavenagande e depois a mamãe pego e fico feliz.

$\mathrm{V}$ :

- Muito bem, Mathias. Você prestou atenção na história.

As crianças ficam muito dispersas, parecem não querer mais conversar.

$P$ então propõe:

- V, vamos cantar parabéns para o nosso aniversariante? (Vinícius)

Vinícius fica envergonhado. P se aproxima, o abraça e diz:

- Tá com vergonhaaaa!!!

$\mathrm{V}$ :

- Gente, agora nós vamos brincar um pouquinho lá no solário.

\section{Organização da sala após o sono}

\begin{tabular}{|l|l|}
\hline Data & $13 / 09 / 2013$ \\
\hline $\mathbf{N}^{\mathbf{o}}$ registro & 04 \\
\hline Horário & $14 \mathrm{~h} 00 \mathrm{~min}$ às $14 \mathrm{~h} 30 \mathrm{~min}$ \\
\hline Pesquisadora: Lídia Godoi \\
\hline Professoras envolvidas: O e I. \\
\hline Turma: MGI-AB \\
\hline $\begin{array}{l}\text { Crianças presentes:Mathias, Thiago, Vinícius, Matheus, Yasmin, Henrique, Giovana, } \\
\text { Sarah, José, Duda, Dhara, Vinícius, Ingrid, Eduardo, Luiz, Jeferson, Lara, Marcos, Vitor, } \\
\text { Willian (total de 21 crianças). }\end{array}$ \\
\hline
\end{tabular}

\begin{tabular}{|l|l|}
\hline Natureza da atividade e materiais & Atividade dirigida após a escuta das histórias. \\
\hline $\begin{array}{l}\text { Participação das crianças e produções } \\
\text { coletivas e individuais }\end{array}$ & Boa parte das crianças participou. \\
\hline $\begin{array}{l}\text { Comunicação: Adulto-criança / } \\
\text { criança-criança }\end{array}$ & $\begin{array}{l}\text { Adulto-criança: a interação se deu à medida que } \\
\text { as professoras auxiliavam as crianças na } \\
\text { organização. } \\
\text { Criança-criança: as interações entre as crianças }\end{array}$ \\
\hline
\end{tabular}




\begin{tabular}{|l|l|}
\hline & $\begin{array}{l}\text { foram diversas, ajudavam-se mutuamente, } \\
\text { falavam das meias, sapatos etc. }\end{array}$ \\
\hline $\begin{array}{l}\text { Acontecimentos planejados e } \\
\text { imprevistos }\end{array}$ & Esta não é uma atividade planejada. \\
\hline
\end{tabular}

\section{Relatório}

Enquanto as crianças vão acordando, I os orienta:

- Hoje, nós vamos ter que tirar os lençóis do colchão, porque vamos colocar para lavar.

Aos poucos, as crianças vão levantando e organizando a sala.

Vivi e Dhara pegam juntos um colchão e colocam perto da parede, junto com os demais. As crianças se dirigem ao tapete e começam a colocar os sapatos. Conversam sobre suas meias.

Sarah fala para Vivi:

- Olia, eu tenho uma meia de uso.

Do outro lado, percebo Jeferson colocando o tênis no Mathias. Ao terminar, Jeferson diz:

- Bigado, amiguinho. Os dois se abraçam.

Escuto uma conversa do Marcos com a $\mathrm{O}$.

Marcos:

- Eu ouvi a história do monsto, O.

O:

- Ah é? E quem contou?

Marcos:

- Foi a possessola.

O levanta e diz:

- Pessoal, senta na beiradinha do tapete pra gente conversar.

O explica a rotina para as crianças:

- Olha, hoje a gente vai descer tomar café, e depois subir para fazer a biblioteca.

\section{Biblioteca itinerante}

\begin{tabular}{|l|l|}
\hline Data & $13 / 09 / 2013$ \\
\hline $\mathbf{N}^{\mathbf{o}}$ registro & 05 \\
\hline Horário & $15 \mathrm{~h} 00 \mathrm{~min}$ às $15 \mathrm{~h} 24 \mathrm{~min}$ \\
\hline Pesquisadora: Lídia Godoi \\
\hline Professoras envolvidas: O e I. \\
\hline Turma: MGI-AB \\
\hline $\begin{array}{l}\text { Crianças presentes: Mathias, Thiago, Vinícius, Matheus, Yasmin, Henrique, Giovana, } \\
\text { Sarah, José, Duda, Dhara, Vinícius, Ingrid, Eduardo, Luiz, Jeferson, Lara, Marcos, Vitor, } \\
\text { Willian (total de 21 crianças). }\end{array}$ \\
\hline
\end{tabular}




\begin{tabular}{|l|l|}
\hline & itinerante". \\
\hline $\begin{array}{l}\text { Participação das crianças e produções } \\
\text { coletivas e individuais }\end{array}$ & Houve boa participação das crianças. \\
\hline $\begin{array}{l}\text { Comunicação: Adulto-criança / } \\
\text { criança-criança }\end{array}$ & $\begin{array}{l}\text { Adulto-criança: deu-se por meio do diálogo. } \\
\text { Criança-criança: não verbal, mas através de } \\
\text { gestos, sorrisos, olhares etc. }\end{array}$ \\
\hline $\begin{array}{l}\text { Acontecimentos planejados e } \\
\text { imprevistos }\end{array}$ & Tudo ocorreu de acordo com o planejado. \\
\hline
\end{tabular}

\section{Relatório}

A biblioteca itinerante é um projeto de leitura em que as crianças emprestam da escola livros para levarem para casa na sexta-feira e ler com as famílias no final de semana. $\mathrm{Na}$ segunda-feira, as professoras fazem uma roda com as crianças, pela manhã, em que elas contam como foi a experiência. Cada sala tem sua caixa de livros para empréstimo.

Antes de emprestar os livros para o final de semana, as professoras apresentam os títulos que elas podem levar. Esses títulos são os mesmos durante certo período, de forma que as crianças conhecem todos que não tenham levado ainda. Cada título é apresentado e colocado no meio da roda para que depois as crianças possam escolher o que querem levar. Ao voltar do lanche, $\mathrm{O}$ convida as crianças para se sentarem no tapete:

- A gente vai mostrar os livros para a Lídia. A I vai mostrar os livros.

Ao mostrar o primeiro, Mathias nem espera I falar e já se pronuncia:

- Esse é o tamanduá!

I pega outro título e diz:

- E esse quem conhece?

Ingrid:

- Eu levei esse!

Dhara:

- O piolho foi o que eu levei, minha mãe contou.

I pega outro livro e diz:

- Ihhhh, esse acho que todo mundo vai saber.

Zé:

- Panela de arrozi. Eu que levei.

I pega outro na caixa:

- Ihhh. Olha esse é bem bacana.

Yasmin:

- É molangovemelho.

Marcos:

- Eu quero levar do pônei.

I:

- Esse acho que ninguém sabe o nome.

Giovana:

- O rato do campo e o rato da cidade.

I:

- E esse aqui, gente?

Henrique olha e diz:

- É um gibi.

I: 
- Ahhh. Esse é difícil o nome em!

Sarah:

- A tecelina!

Vitor interrompe e diz:

- O Vini comeu o livro.

Após apresentar todos os livros, I chama as crianças uma a uma para escolher.

Duda escolhe o mesmo da semana passada.

I tenta convencê-la a trocar:

- Você já levou esse, Duda. Não quer trocar?

Duda balança a cabeça sinalizando o não.

I:

- Então tá bom.

Matheus Nogueira escolheu um livro bem grande. I coloca-o na pasta, mas fica um pedaço para fora. Matheus então a repreende dizendo:

- Arruma direito!

Todos escolheram seu livro. Restaram alguns no tapete.

I:

- Agora vamos escolher um desses que restou para ler. Temos dois aqui. "Tenho medo mais dou um jeito" e "De hora em hora". Os dois são da Ruth Rocha.

As professoras decidem fazer uma votação.

O diz:

-Olha, a $\mathrm{O}$ vai escrever aqui desse lado: tenho medo mais dou um jeito, e do outro: de hora em hora. Vocês vão escolher e cada um que escolher, eu vou marcar uma bolinha aqui.

Ao final da votação, todos contam os votos com a professora. As crianças iriam ouvir: "Tenho medo mais dou um jeito".

\section{Áreas de interesse}

\begin{tabular}{|l|l|}
\hline Data & $13 / 09 / 2013$ \\
\hline $\mathbf{N}^{0}$ registro & 06 \\
\hline Horário & $15 \mathrm{~h} 25 \mathrm{~min}$ às $16 \mathrm{~h} 15 \mathrm{~min}$ \\
\hline Pesquisadora: Lídia Godoi \\
\hline Professoras envolvidas: O e I. \\
\hline Turma: MGI-AB \\
\hline $\begin{array}{l}\text { Crianças presentes: Mathias, Thiago, Vinícius, Matheus, Yasmin, Henrique, Giovana, } \\
\text { Sarah, José, Duda, Dhara, Vinícius, Ingrid, Eduardo, Luiz, Jeferson, Lara, Marcos, Vitor, } \\
\text { Willian (total de 21 crianças). }\end{array}$ \\
\hline
\end{tabular}

\begin{tabular}{|l|l|}
\hline Natureza da atividade e materiais & Brincar livre nas áreas de interesse. \\
\hline $\begin{array}{l}\text { Participação das crianças e produções } \\
\text { coletivas e individuais }\end{array}$ & Houve boa participação das crianças. \\
\hline Comunicação: Adulto-criança / & Adulto-criança: as professoras permaneceram \\
\hline
\end{tabular}




\begin{tabular}{|l|l|}
\hline criança-criança & $\begin{array}{l}\text { durante todo o momento brincando junto com as } \\
\text { crianças. } \\
\text { Criança-criança: as crianças brincam juntas e } \\
\text { conversam entre si. }\end{array}$ \\
\hline $\begin{array}{l}\text { Acontecimentos planejados e } \\
\text { imprevistos }\end{array}$ & Tudo ocorreu de acordo com o planejado. \\
\hline
\end{tabular}

\section{Relatório}

Depois de contarem a história "Tenho medo mas dou um jeito", as professoras fizeram uma votação entre as crianças para que escolhessem entre brincar no parque ou nas áreas de interesse dispostas na sala. A escolha foi pelas áreas de interesse.

$\mathrm{Na}$ sala, as áreas de interesse estão sempre montadas. São: área da casinha, sorveteria, cabelereiro, fantasia, construção, leitura e artes. Na área da construção, tem alguns jogos de boliche, caixa de ferramentas, carrinhos, casinha. Há muitas panelinhas e pratinhos de plástico, cama com algumas bonecas, mesa, ferro de passar, varal com roupas penduradas. Na sorveteria, existe um brinquedo grande com potes e sorvetinhos de brinquedo, como se fosse um carrinho de sorvete mesmo. Na fantasia, existem sapatos, bolsas, lenços, fantasias. $\mathrm{Na}$ área de artes, há uma mesinha e uma prateleira com massinha, canetinha, giz de cera pinceis, tinta, tesoura, lápis de escrever. $\mathrm{Na}$ área do cabelereiro, existem maquiagens, esmaltes, batons, pentes, laços para cabelo, potinho com água para borrifar nos cabelos. $\mathrm{Na}$ área da leitura, ficam livros expostos em um bolsão transparente na altura das crianças.

Percebo Mathias e Thiago brincando na área da construção, tentando encaixar as ferramentas umas nas outras.

Mathias pega o carro e algumas ferramentas e diz:

- Tôconcetando meu carro. Vou pegar uma feamenta!

Duda e Dhara brincam juntas na sorveteria. Duda faz o sorvete e dá na mão da Dhara que diz:

- Bigado!

Marcos está passando o batom. Aproxima-se de Vivi e diz:

-Eu tenho, eu tenho batom.

Ingrid diz para ele:

- O batom passa aqui ó! Na boca. No olho não!

Vivi está sentada em uma cadeirinha concentrada pintando a unha.

Ingrid se aproxima e diz:

- Você vai fazer o meu?

Marcos pergunta a Ingrid:

- Do que é o seu batom?

Ingrid responde:

- É de uva, e o seu é de laranja.

Marcos:

- Eu tenho um batom de Ben 10 lá na minha casa.

O se aproxima e diz:

- Pessoal! Vamos brincar de salão. Eu sou a cabelereira e a I é a maquiadora!

Lara, que estava de fantasias e sapatos de salto alto, é a primeira da fila.

Percebo que Dhara voltou para a sorveteria. Lá, agora havia massinha e mais alguns potes. Acho que a $\mathrm{O}$ que colocou.

Lá na maquiagem, percebo a $\mathrm{O}$ interagindo com as crianças.

- Duda empresta o creme de cabelo para a O. Gi, você é maquiadora? Quer passar a 
maquiagem na Lara?

Marcos se aproxima com o batom e O pergunta:

- Lara, o Marcos pode passar o batom em você?

Lara afirma com um movimento de balançar a cabeça que sim.

Vivi está precisando de um batom. A pergunta para a turma:

- Alguém pode emprestar um batom para a Vivi?

Marcos:

- Eu empesto!

Dhara se aproxima e pede para que o Marcos passe batom nela.

Marcos diz que sim e passa.

Do outro lado da sala, observo o movimento de Henrique, Vini, Vitor e Matheus. Eles pegaram o boliche e criaram uma nova brincadeira. Com os pinos, eles acertam a bola. Como se estivessem jogando golfe. Um acerta a bola e o outro tem que alcançá-la e acertála também. Quem conseguir acertar a bola na parede faz o gol.

Mathias e Jeferson agora brincam na casinha.

Mathias:

- Eu tô fazendo tota. É tota de carro de buzina igual a esse.

No outro canto, na área do cabelereiro, estão Duda, Giovana, Yasmin, Dhara e Ingrid. I está maquiando-as.

Mathias, que estava fazendo a torta, vem até mim e diz:

- Lídia, a tota tá pronta (dando-me o pratinho cheio de massinha verde).

Pego e finjo experimentar:

- Huum... Que delícia!

Zé se aproxima. Mahias pega outro prato e diz:

- Essa é pra você, Zé.

Percebo alguém na área de artes. Até o momento, ninguém tinha ido lá. É Vivi. Ela pega um molde de coração. Faz o desenho e depois recorta. Ficou nesse movimento por um bom tempo.

O está agora circulando pelas áreas organizando os materiais. Vira para mim e fala:

- Tô arrumando um pouco. Para melhorar a organização e surgir novos interesses.

$\mathrm{Na}$ área de artes, Dhara se aproxima de Vivi. Ela pega um caderninho uma canetinha e diz:

- Eu agora vou desenhar.

O diz que elas iriam propor ir ao solário, mas a brincadeira está tão intensa que vão permanecer ali mesmo.

Vini, Henrique, Matheus e Vitor continuam na maior farra, brincando da mesma brincadeira que inventaram no início.

\section{Impressões gerais}

\section{3/09/2013 - IMPRESSÕES GERAIS - MANHÃ}

Hoje, o momento da acolhida foi pensado de forma a garantir as crianças momentos de escolha. Não só a escolha entre brincar com jogos de encaixe ou fazer leitura. As crianças puderam também escolher com quem brincar, como brincar, que materiais utilizar. Dessa forma, uns preferiram o faz de conta, outros construírem coisas, outros ainda preferiram contar histórias aos colegas. Ao chegarem ao CEI, as crianças já puderam optar por espaços, materiais e colegas de trabalho. $\mathrm{O}$ fato de as professoras se dividirem demonstra uma preocupação e um cuidado com a criança. Enquanto uma recebe, a outra auxilia na 
organização dos materiais e também nos cuidados com o corpo e os pertences. As práticas sociais, como guardar os pertences, tirar a blusa, guardar as agendas, são também uma forma de expressão, uma expressão que se dá pelo gesto. Assim, os movimentos das professoras auxiliando as crianças no guardar, colocar e tirar a roupa, são por elas apreendidos, ou seja, é também uma aprendizagem contemplada na ação pedagógica.

Notei também que o CEI já incorporou em sua rotina a prática de leitura. O que é positivo, já que as crianças constroem cultura no contato com as formas e manifestações culturais. Nesse sentido, essas práticas são importantes para subsidiar a construção de novos saberes pelas crianças. A existência de tempos e espaços demarcados, hora para começar e hora para terminar, tudo prejudicou a experiência das crianças. Isso é o que prevalece. Infelizmente, parece que as experiências das crianças são determinadas pelo tempo institucional.

\section{4/09/2013 - IMPRESSÕES GERAIS - TARDE}

Sinto que as professoras, tanto durante a manhã como à tarde, estão sempre incentivando e dando a oportunidade para que as crianças desenvolvam sua autonomia. Durante a organização da sala após o sono, notei que as professoras I e $\mathrm{O}$ auxiliavam as crianças a colocar os sapatos, mas não colocavam para elas. Notei que, para a turma, ajudar na organização do espaço é uma constante. Depois da brincadeira, ao acordar, depois da acolhida, num clima amigável e de cooperação possibilitado pelo momento e pelas práticas na sala, pelo trato das professoras com relação às crianças, pelas formas como elas se relacionam com meninos e meninas, as crianças aprendem também a se relacionar e construir formas de convívio mais solidárias.

$19 / 09 / 2013$

Acolhida das crianças

\begin{tabular}{|l|l|}
\hline Data & $19 / 09 / 2013$ \\
\hline $\mathbf{N}^{\mathbf{0}}$ registro & 01 \\
\hline Horário & 08h00min às 08h30min \\
\hline Pesquisadora: Lídia Godoi \\
\hline Professoras envolvidas: P. \\
\hline Turma: MGI-AB \\
\hline $\begin{array}{l}\text { Crianças presentes:Jorge, Thiago, Vinícius, Matheus, Yasmin, Henrique, Sarah, José, } \\
\text { Duda, Vinícius, Ingrid, Eduardo, Luiz, Jeferson, Lara, Marcos, Vitor (total de 17 crianças). }\end{array}$ \\
\hline
\end{tabular}

\begin{tabular}{|l|l|}
\hline Natureza da atividade e materiais & Acolhida. Atividade permanente. \\
\hline $\begin{array}{l}\text { Participação das crianças e produções } \\
\text { coletivas e individuais }\end{array}$ & Todas as crianças participam. \\
\hline Comunicação: Adulto-criança / & Adulto-criança: oral e gestual bem presente \\
\hline
\end{tabular}




\begin{tabular}{|l|l|}
\hline criança-criança & $\begin{array}{l}\text { durante todo o momento da acolhida. } \\
\text { Criança-criança: as crianças brincam juntas e } \\
\text { conversam entre si. }\end{array}$ \\
\hline $\begin{array}{l}\text { Acontecimentos planejados e } \\
\text { imprevistos }\end{array}$ & $\begin{array}{l}\text { O espaço foi planejado para receber as crianças } \\
\text { proporcionando-lhes escolhas. Não houve } \\
\text { imprevistos. }\end{array}$ \\
\hline
\end{tabular}

\section{Relatório}

Hoje, a professora $\mathrm{P}$ ficará sozinha em sala, pois sua parceira $\mathrm{V}$ fez uma cirurgia e está de licença por um mês. Essa semana está chuvosa, então as crianças não estão indo ao parque. Hoje, a sala conta com 17 crianças. Dessas 17, cinco serão redistribuídas em outras salas, pois não há, no CEI, professor disponível para substituir a $\mathrm{V}$.

$\mathrm{P}$ disponibiliza dois tipos diferentes de jogos de encaixar. Dessa forma, enquanto ela recebia e orientava as crianças que chegavam, as outras brincavam com os jogos.

P está recebendo Vivi, Thiago, Lara e Henrique, ajudando-os com as mochilas.

P:

- Matheus, você já tirou a mochila? Thiago, vem aqui pra gente tirar essa blusa de frio. Agachada na altura das crianças, $\mathrm{P}$ os auxilia com as blusas, mochilas e agendas.

Enquanto isso, Vitor, Vini, Vivi e Ingrid montam uma torre utilizando as peças dos jogos de encaixe. Vivi e Ingrid trabalham juntas. Vivi pega as peças e as entrega para Ingrid para que ela coloque na torre.

Jorge chega com algumas peças para colocar na torre. Vivi não aceita e diz:

- Já tá bom, tá bom.

Lara, que acaba de chegar, está sentada ao lado da mochila, observando os colegas.

Vivi, Ingrid, Duda e Vitor começam a cantar parabéns pra você em volta da torre que construíram. Marcos, Matheus, Jorge e Vini correm pela sala. Ao perceber,P diz:

- Eles estão agitados, você vê, né? Eles estão sempre tranquilos na acolhida. É que essa semana está chovendo muito e eles não estão indo ao parque. Então, você imagina. Por mais possibilidades que eles tenham na sala, passar 10 horas dentro de uma sala...

Luiz Gustavo chega acompanhado da mãe. P o recebe com bastante alegria e sorrisos.

- Ah, você chegou! Vamos tirar o casaco?

P continua conversando algo com a mãe, mas estou envolvida com as crianças, observandoas com os jogos de encaixe.

Thiago e Jeferson estão brincando juntos, construindo uma espécie de torre com as peças. Estão tão concentrados que nem conversam entre si.

Duda está tentando guardar a blusa na mochila e se irrita porque não consegue. $\mathrm{P}$ percebe e vem ajudá-la.

Lara, Ingrid, Vivi e Vitor estão em volta da torre construída por Ingrid e Vivi cantando parabéns.

O portão lá embaixo já fechou. $\mathrm{P}$ chama as crianças:

-Turminha! Hora de guardar.

Ela pega duas caixas mostra as peças do jogo e diz:

- Estas são aqui nessa caixa. Estas outras são nessa caixa aqui.

Zé traz a peça e coloca na caixa correspondente. P diz:

- Isso Zé, muito bem! 
Sarah chega logo em seguida. P agradece:

- Obrigado, Sarah, muito bem!

P:

- Deixa eu ver se a Maria Eduarda está ajudando.

$\mathrm{P}$ vai incentivando as crianças a guardar.

- Obrigada,Vini!

- Obrigada, Jorge!

Todos estão envolvidos em guardar brinquedos. $\mathrm{P}$ está perto das caixas auxiliando as crianças na separação das peças.

\section{Brincar livre no parque}

\begin{tabular}{|c|c|}
\hline Data & $19 / 09 / 2013$ \\
\hline $\mathrm{N}^{0}$ registro & 02 \\
\hline Horário & $08 \mathrm{~h} 50 \mathrm{~min}$ às $09 \mathrm{~h} 35 \mathrm{~min}$ \\
\hline \multicolumn{2}{|c|}{ Pesquisadora: Lídia Godoi } \\
\hline \multicolumn{2}{|c|}{ Professoras envolvidas: $P$. } \\
\hline \multicolumn{2}{|c|}{ Turma: MGI-AB } \\
\hline $\begin{array}{l}\text { Crianças pr } \\
\text { Duda, Viníc }\end{array}$ & $\begin{array}{l}\text { entes:Jorge, Thiago, Vinícius, Matheus, Yasmin, Henrique, Sarah, José, } \\
\text { s, Ingrid, Eduardo, Luiz, Jeferson, Lara, Marcos, Vitor (total de } 17 \text { crianças). }\end{array}$ \\
\hline
\end{tabular}

\begin{tabular}{|l|l|}
\hline Natureza da atividade e materiais & $\begin{array}{l}\text { Brincar livre no parque/ Atividade permanente / } \\
\text { acontece desde que não esteja chovendo. }\end{array}$ \\
\hline $\begin{array}{l}\text { Participação das crianças e produções } \\
\text { coletivas e individuais }\end{array}$ & Todas as crianças participam. \\
\hline $\begin{array}{l}\text { Comunicação: Adulto-criança / } \\
\text { criança-criança }\end{array}$ & $\begin{array}{l}\text { Adulto-criança: pouca, a comunicação só } \\
\text { ocorreu nos momentos em que as crianças } \\
\text { solicitavam algum cuidado. } \\
\text { Criança-criança: privilegiada, as crianças } \\
\text { conversam entre si e organizam juntas suas } \\
\text { brincadeiras. }\end{array}$ \\
\hline $\begin{array}{l}\text { Acontecimentos planejados e } \\
\text { imprevistos }\end{array}$ & $\begin{array}{l}\text { O brincar livre no parque é uma atividade } \\
\text { permanente que acontece todos os dias desde } \\
\text { que não esteja chovendo. }\end{array}$ \\
\hline
\end{tabular}

\section{Relatório}

$\mathrm{Na}$ área coberta do parque, estão disponíveis motocas, triciclos, baldes e pazinhas para brincar com areia.

Eduardo pega um balde e coloca na cabeça como se fosse um chapéu.

A turma do B-II também está nesse espaço. 
Percebo Sarah, Ingrid e Vitor com algumas folhas em um balde. Com o uso da pazinha, eles mexem as folhas como se fosse comida.

Ingrid oferece para Marcos:

- Quer um pouquinho?

Vitor despeja o que tem em seu balde no balde da Ingrid. Ela pergunta:

- Cê não quer mais? Quer um pouquinho?

Ingrid coloca um pouco no balde de Vitor, dizendo:

- Tó, só um pouquinho!

Ingrid e Vitor estão em pé, mexendo as folhas na bacia. Sarah está agachada ao lado deles. Ingrid abaixa-se e joga algumas folhas no chão para Sarah, dizendo:

- Pega vai!

Agora que percebi! Sarah é o cachorrinho. As crianças estão envolvidas em um faz de conta em que Sarah é um cachorrinho, Vitor e Ingrid são seus donos.

Ingrid fala para o Vitor:

- Olha ai, eu dei uma comidinha para o cachorrinho!

Ingrid e Vitor dão uma volta pelo espaço e param perto de um triciclo.

Ingrid:

- Vitor! Coloca aqui. Convidando-o para vir mexer a "comidinha" perto dela.

Os dois em pé mechem a comida.

Thiago se aproxima de Ingrid com o triciclo.

Ingrid fala para ele:

- Olha a buzina, a buzina faz "bibi”!

Ingrid e Vitor voltam ao local que Sarah está ainda de joelhos imitando um cachorrinho.

Vitor coloca o balde perto de Sarah. Vivi joga a "ração" e Sarah finge comer.

Ingrid pega o triciclo para dar uma volta. Sarah segue atrás ainda como cachorrinho atrás do dono. Sarah fez todo o percurso atrás de Ingrid.

Ingrid pergunta:

- Quer?

Joga as folhas para Sarah como se fosse ração.

Vivi se aproxima de Sarah e Ingrid, imitando cachorrinho também.

Ingrid alimenta as duas.

Elas não conversam. Compreendem o papel que estão representando no jogo. O cachorro não fala.

Ingrid joga a ração e fala:

- Vai, vai!

Vivi dá voltas atrás de Ingrid.

Vivi e Sarah (as cachorrinhas) deitam no colo de Ingrid para que ela as acariciem.

Vivi são Ingrid diz:

- Que foi? (fazendo carinho em Vivi e dando-lhe a ração na boca, como se fosse uma cachorrinha mesmo).

Ingrid faz brincadeiras com Sarah jogando a comida para ela pegar.

Sarah e Vivi (as cachorrinhas) não falam com Ingrid em momento nenhum.

Ingrid arruma a ração nos potes (tampas de potes) para elas comerem.

Vivi agora é a nona da cachorrinha também.

Só há uma cachorrinha, Sarah.

Vivi coloca ração para a cachorrinha e pergunta:

- Quer?

Ingrid ensina a cuidar.

- Dá dessa daqui pá ela não come ó.

Sarah (a cachorrinha) não aceita. 
Ingrid:

- É porque essa não come ó.

Nesse momento, $\mathrm{P}$ chama as crianças. Eles irão agora assistir a um filme.

\section{Organização da sala após o sono}

\begin{tabular}{|c|c|}
\hline Data & $19 / 09 / 2013$ \\
\hline $\mathrm{N}^{0}$ registro & 03 \\
\hline Horário & $14 \mathrm{~h} 20 \mathrm{~min}$ às $15 \mathrm{~h} 10 \mathrm{~min}$ \\
\hline \multicolumn{2}{|c|}{ Pesquisadora: Lídia Godoi } \\
\hline \multicolumn{2}{|c|}{ Professoras envolvidas: O e I. } \\
\hline \multicolumn{2}{|c|}{ Turma: MGI-AB } \\
\hline $\begin{array}{l}\text { Crianças pr } \\
\text { Duda, Viníci }\end{array}$ & $\begin{array}{l}\text { entes: Jorge, Thiago, Vinícius, Matheus, Yasmin, Henrique, Sarah, José, } \\
\text {, Ingrid, Eduardo, Luiz, Jeferson, Lara, Marcos, Vitor (total de } 17 \text { crianças). }\end{array}$ \\
\hline
\end{tabular}

\begin{tabular}{|l|l|}
\hline Natureza da atividade e materiais & Organização da sala após o sono. \\
\hline $\begin{array}{l}\text { Participação das crianças e produções } \\
\text { coletivas e individuais }\end{array}$ & Todas as crianças participam. \\
\hline $\begin{array}{l}\text { Comunicação: Adulto-criança / } \\
\text { criança-criança }\end{array}$ & $\begin{array}{l}\text { Adulto-criança: as professoras incentivam e } \\
\text { elogiam as crianças na organização da sala. } \\
\text { Predominância da linguagem oral e gestual. } \\
\text { Criança-criança: conversam entre si, ajudam } \\
\text { umas as outras. Predomina a linguagem oral e } \\
\text { gestual. }\end{array}$ \\
\hline $\begin{array}{l}\text { Acontecimentos planejados e } \\
\text { imprevistos }\end{array}$ & Pagerala \\
\hline
\end{tabular}

\section{Relatório}

São 14h20min e as crianças estão começando a acordar. As professoras I e O começam a organizar a sala com aqueles que já acordaram.

Eduardo está tentando tirar o lençol do colchão.

I:

- Vem aqui, Eduardo, deixa eu te ajudar.

Marcos percebe que está filmando.

- Ó tia, você está tirando foto de novo?

Vitor está empenhado em tirar o lençol.

As crianças estão trabalhando, guardam os lençóis dentro dos saquinhos. Algumas ainda 
dormem.

Vivi e Sarah se aproximam de Lara e tentam acordá-la.

Vivi:

- Vai acorda!

Enquanto as crianças se organizam na sala com a I, a AD acompanha aqueles que estão no banheiro.

Ingrid, Jeferson, Vitor e Marcos conversam:

Ingrid:

- Lá na minha casa tem brinquedo de menina. Eu vou na casa sabe de quem, Marcos? Eu vou na casa do tio Bento, lá tem o Vitor, a Érica... Tem muitas coisas lá.

As meninas riem.

O, do outro lado da sala, auxilia a Lara a trocar de roupa.

Há um repentino silêncio. As crianças estão concentradas em colocar os sapatos.

Vou ao banheiro e lá estão R, Eduardo e Thiago. As crianças usam o banheiro e depois lavam as mãos sozinhas. Em seguida, pegam o papel e secam. Todos esses objetos, sabão, papel, estão de fácil acesso para as crianças.

Percebo Vivi colocando os sapatos no Zé.

Vivi:

- Zé, é assim ó! (dando o laço no sapato).

Sarah se aproxima para tentar ajudar e Vivi diz:

- Ele não quer!

Vivi e Ingrid conversam sobre as imagens que têm em sua roupa.

Vivi:

- Na minha tem flor.

Ingrid:

- Na minha tem flor também.

Vivi:

- Na minha tem borboleta.

Ingrid:

- Na minha também.

O convida as crianças para a roda.

- Vamos sentar na beiradinha do tapete.

A pergunta:

- Quem ficou com a Elaine hoje?

Todos dizem:

- Eu!

Lara:

- Eu, o Jeferson, Luiz e o Marcos.

Sarah:

- Oh! A gente viu o vídeo que a princesa deu o beijo no sapo. A princesa beijou o sapo, aí a princesa virou uma sapa.

O dá uma gargalhada e diz:

- Sério? Então não pode beijar o sapo que vira sapa?

Ingrid:

- Porque a sapinha beijou o príncipe.

$\mathrm{O}$ :

- E aí, ela virou uma princesa?

Lara:

- A bruxa pegou o...

Vivi: 
- Não tem bicho lá.

Marcos:

- Tem bicho, eu vi um bicho.

Todos falam ao mesmo tempo.

O diz:

- Pera aí, gente, a Vivi vai falar.

Vivi:

- A princesa beijou o príncipe e virou uma sapa.

$\mathrm{O}$ :

- O que você queria falar, Thiago?

Thiago timidamente diz:

- Ela beijou o príncipe.

$\mathrm{O}$ :

- E o que ela virou?

Algumas crianças dizem: "uma sapa".

Thiago:

- Uma sapa.

$\mathrm{O}$ :

- E qual que era o nome dessa história?

Sarah:

- Ó, O, ó, a princesa beijou o sapo e virou uma sapa.

$\mathrm{O}:$

- Mas você lembra o nome dessa história?

As crianças gritam dizendo que se lembravam.

$\mathrm{O}$ :

- Tá, o Vitinho vai falar agora.

Eduardo grita:

- É família verde!

$\mathrm{O}$ :

- É Família verde?

Sarah:

- Não! Oh, é assim, a princesa beijou o sapo e virou uma sapa.

$\mathrm{O}$ :

- Isso eu já entendi, Sarah.

$\mathrm{O}$ :

- Mas o Eduardo disse que o nome é família verde.

Sarah:

- Não, não é.

$\mathrm{O}$ :

- Depois vocês descobrem pra mim o nome dessa história.

Vivi:

- A língua do sapo era menor.

Marcos:

- O, e o sapo demorou um ano para o casamento.

$\mathrm{O}$ :

- E depois o sapo virou príncipe?

Vitor:

- Virou.

Thiago:

- A sapa virou princesa. 
O:

- Zé, você gostou dessa história.

Marcos:

- Mais eu vi, o sapo casou com a princesa e beijou na boca. O jacaré abriu a boca e fechou a boca.

O:

- Tinha castelo nesse filme?

Matheus:

- Cortou uma árvore e os dois jacarés que mordam.

Vivi:

- O jacaré abriu a boca e subiu na água e...

Marcos:

- Ela puxou com a língua assim.

O:

- Eu vou contar pra P que vocês gostaram dessa história. Deixa a Duda falar um pouquinho, ela não falou nada. Depois a gente encerra, porque vamos ter que descer porque já esta tarde. Na volta, se vocês quiserem, agente continua falando sobre isso.

Lara:

$-\mathrm{E} .$.

O:

- Fala, Duda!

Duda:

- O jacaré abriu a boca e comeu a árvore.

O e I convidam a turma para lavar as mãos e tomar o café.

\section{Alimentação logo após o sono}

\begin{tabular}{|c|c|}
\hline Data & $19 / 09 / 2013$ \\
\hline $\mathrm{N}^{\mathbf{o}}$ registro & 04 \\
\hline Horário & 14h50min às $15 \mathrm{~h} 10 \mathrm{~min}$ \\
\hline \multicolumn{2}{|c|}{ Pesquisadora: Lídia Godoi } \\
\hline \multicolumn{2}{|c|}{ Professoras envolvidas: $\mathrm{O}$ e I. } \\
\hline \multicolumn{2}{|c|}{ Turma: MGI-AB } \\
\hline $\begin{array}{l}\text { Crianças pr } \\
\text { Duda, Viníci }\end{array}$ & $\begin{array}{l}\text { entes:Jorge, Thiago, Vinícius, Matheus, Yasmin, Henrique, Sarah, José, } \\
\text { s, Ingrid, Eduardo, Luiz, Jeferson, Lara, Marcos, Vitor (total de } 17 \text { crianças). }\end{array}$ \\
\hline
\end{tabular}




\begin{tabular}{|l|l|}
\hline Natureza da atividade e materiais & Momento da alimentação após o repouso. \\
\hline $\begin{array}{l}\text { Participação das crianças e produções } \\
\text { coletivas e individuais }\end{array}$ & Todas as crianças participam. \\
\hline $\begin{array}{l}\text { Comunicação: Adulto-criança / } \\
\text { criança-criança }\end{array}$ & $\begin{array}{l}\text { Adulto-criança: as professoras conversam com } \\
\text { as crianças e as incentivam a se alimentar. } \\
\text { Criança-criança: as crianças conversam bastante } \\
\text { entre si na hora das refeições. }\end{array}$ \\
\hline $\begin{array}{l}\text { Acontecimentos planejados e } \\
\text { imprevistos }\end{array}$ & \\
\hline
\end{tabular}

\section{Relatório}

Descemos para tomar o leite.

As crianças organizaram-se em uma fila e cada uma pega seu copo e leva à mesa. Ao término, devolvem o copo na janelinha da cozinha, onde as refeições são servidas.

Sentados à mesa, Marcos e Vitor conversam ainda sobre o filme.

Marcos:

- O príncipe beijou ela e ela virou uma sapa.

Vitor:

- Não é beijar na bochecha, é na boca.

As crianças terminam de tomar o leite e dirigem-se às escadas sentando nos degraus, formando um tipo de arquibancada. Lá, O está esperando-os.

$\mathrm{O}$ :

- Vamos mostrar para Lídia a nossa ôlaaaaa... Então no forte. As crianças gritam alto e levantam as mãos.

Jorge:

- Agora forte.

Todos fazem ôlaaaa.

Ingrid:

-Certo.

$\mathrm{O}$ :

- Agora longo 1, 2, 3!

Todos:

- Ôlaaaaaa!

$\mathrm{O}$ :

- E agora? Como a gente faz?

Luiz:

- Forte.

Todos:

- Ôlaaaaaaaaaaaa!

Pergunto à $\mathrm{O}$ de onde surgiu essa ideia de "ôla", pois imaginei que tivesse algo a ver com a pesquisa sonora.

$\mathrm{O}$ :

- Eu faço com as crianças desde o ano passado. No começo, foi intuitivamente só para espairecer mesmo. Agora, faço intencional para experimentar a diversão e a intensidade dos sons. Por isso, Sarah, naquele dia (o dia da experiência com pesquisa sonora) sabia dizer se o som era forte ou fraco. 


\section{Roda de conversa}

\begin{tabular}{|c|c|}
\hline Data & 19/09/2013 \\
\hline $\mathrm{N}^{0}$ registro & 05 \\
\hline Horário & $15 \mathrm{~h} 13 \mathrm{~min}$ às $15 \mathrm{~h} 20 \mathrm{~min}$ \\
\hline \multicolumn{2}{|c|}{ Pesquisadora: Lídia Godoi } \\
\hline \multicolumn{2}{|c|}{ Professoras envolvidas: $O$ e I. } \\
\hline \multicolumn{2}{|c|}{ Turma: MGI-AB } \\
\hline $\begin{array}{l}\text { Crianças pr } \\
\text { Duda, Viníci }\end{array}$ & $\begin{array}{l}\text { entes:Jorge, Thiago, Vinícius, Matheus, Yasmin, Henrique, Sarah, José, } \\
\text { s, Ingrid, Eduardo, Luiz, Jeferson, Lara, Marcos, Vitor (total de } 17 \text { crianças). }\end{array}$ \\
\hline
\end{tabular}

\begin{tabular}{|l|l|}
\hline Natureza da atividade e materiais & $\begin{array}{l}\text { Roda de conversa/ atividade permanente / } \\
\text { acontece em vários momentos do dia. }\end{array}$ \\
\hline $\begin{array}{l}\text { Participação das crianças e produções } \\
\text { coletivas e individuais }\end{array}$ & Todas as crianças participam. \\
\hline $\begin{array}{l}\text { Comunicação: Adulto-criança / } \\
\text { criança-criança }\end{array}$ & $\begin{array}{l}\text { Adulto-criança: Há um diálogo estabelecido } \\
\text { entre as crianças e as professoras, a fim de } \\
\text { definir que atividades farão durante a tarde. } \\
\text { Criança-criança: as crianças conversam menos } \\
\text { entre si, prevalecendo o diálogo com os adultos. }\end{array}$ \\
\hline $\begin{array}{l}\text { Acontecimentos planejados e } \\
\text { imprevistos }\end{array}$ & \begin{tabular}{l}
\hline \\
\hline
\end{tabular}
\end{tabular}

\section{Relatório}

Ao entrar na sala, as crianças sentam-se diante do tapete, fazendo uma roda.

A explica:

- Oh! Lembra que a gente desenhou e dançou ao mesmo tempo com aquelas músicas diferentes? Então, a gente pensou em fazer isso hoje. O que vocês acham?

Sarah:

- Legal!

Thiago:

- É legal.

O:

- Oh, dá pra fazer duas coisas. Dá pra fazer isso e brincar nos cantinhos.

Ingrid, Henrique e Matheus gritam:

- Eu quero brincar de cantinho!

$\mathrm{O}$ :

- Vocês preferem os cantinhos. Oh! Mas ainda dá pra gente fazer outra coisa. A Duda e a I tinha pensado em desenhar, dançar, mas também vocês lembram daquele lugar que a gente 
brincou lá fora?

Duda:

- Eu lembro.

O:

- Então tá! De cantinho a gente vai brincar. E depois de cantinho, a gente vai dançar ou brincar lá fora.

Sarah:

- A gente quer brincar de cantinho.

O:

- Então tá bom. Então vamos brincar no cantinho.

\section{Brincar livre nas áreas de interesse}

\begin{tabular}{|l|l|}
\hline Data & $19 / 09 / 2013$ \\
\hline $\mathbf{N}^{\mathbf{0}}$ registro & 06 \\
\hline Horário & $15 \mathrm{~h} 20 \mathrm{~min}$ às 15h50min \\
\hline Pesquisadora: Lídia Godoi \\
\hline Professoras envolvidas: O e I. \\
\hline Turma: MGI-AB \\
\hline $\begin{array}{l}\text { Crianças presentes:Jorge, Thiago, Vinícius, Matheus, Yasmin, Henrique, Sarah, José, } \\
\text { Duda, Vinícius, Ingrid, Eduardo, Luiz, Jeferson, Lara, Marcos, Vitor (total de } 17 \text { crianças). }\end{array}$ \\
\hline
\end{tabular}

\begin{tabular}{|l|l|}
\hline Natureza da atividade e materiais & Brincar livre nas áreas de interesse. \\
\hline $\begin{array}{l}\text { Participação das crianças e produções } \\
\text { coletivas e individuais }\end{array}$ & Todas as crianças participam. \\
\hline $\begin{array}{l}\text { Comunicação: Adulto-criança / } \\
\text { criança-criança }\end{array}$ & $\begin{array}{l}\text { Adulto-criança: as professoras interagem e } \\
\text { brincam com as crianças. } \\
\text { Criança-criança: Constante por meio de gestos e } \\
\text { da fala. }\end{array}$ \\
\hline $\begin{array}{l}\text { Acontecimentos planejados e } \\
\text { imprevistos }\end{array}$ & \\
\hline
\end{tabular}

\section{Relatório}

As crianças se espalham pelas áreas. Jorge, com uma chave de fenda, conserta a televisão portátil. Ao perceber que me aproximo, ele diz:

- Oh, oh eu tabaiando, oh eu tabaiando! Tô consertando a televisão.

Lara coloca o mesmo vestido e sapato da semana passada. I me contou que, para facilitar que as crianças colocassem as fantasias sozinhas, elas cortaram e colaram na parte de baixo, 
assim elas conseguem sem ajuda colocar a fantasia.

Vivi, Henrique, Marcos, Matheus e Vitor brincam do mesmo jogo que brincavam semana passada. Eles jogam uma espécie de futebol de mão com os pinos e a bola do boliche. $R$ está brincando com eles.

$\mathrm{Na}$ área de artes estão Vivi, Lara e Luiz brincando com a massinha. Ingrid, Sarah e Sophia brincavam na área do cabeleireiro. Elas não falam, apenas Sarah penteia o cabelo da boneca.

Thiago brinca sozinho na área da caixinha, construindo um carro.

Duda e Jeferson fazem objetos com massinha na área de artes.

Duda mostra sua produção para Jeferson:

- Olha, olha, a bolinha.

Sarah, Duda, Lara, Ingrid e Jeferson estão na área do cabeleireiro. O chega e pergunta:

- Posso brincar também?

As crianças respondem que pode.

Percebo Zé fazendo uma escultura de massinha. Jorge está brincando junto, colocando a massinha dentro de um copinho. Eles estão concentrados em seus projetos e não conversam entre si.

Enquanto isso, Yasmin faz uma maquiagem diante do espelho.

Jeferson pega o pente e leva para área de artes para fazer marcas na massinha.

$\mathrm{Na}$ área de artes, observo Vivi:

Ela está sentada com uma folha sulfite fazendo um desenho que lembrava um espiral.

Depois que termina o desenho, pega uma tesoura e começa a cortar seguindo os traços.

Ela permaneceu nesse movimento por 10 minutos.

Sarah, ao percebê-la também, pega canetinha, tesoura e sulfite. Senta-se no chão, faz desenhos e começa a recortar. Permanece assim por aproximadamente 8 minutos.

O se posiciona no meio da sala e, de pé, chama a atenção das crianças:

- Quem está me escutando põe a mão na barriga. Quem está me escutando põe a mão na cabeça. Aos poucos, as crianças vão prestando atenção.

$\mathrm{O}$ :

- Vocês querem continuar brincando nos cantinhos ou querem brincar no solário?

Todos ajudam na organização da sala, separando cada brinquedo em sua área junto com as professoras.

\section{Brincar livre no solário}

\begin{tabular}{|c|c|}
\hline Data & $19 / 09 / 2013$ \\
\hline $\mathrm{N}^{\mathbf{0}}$ registro & 07 \\
\hline Horário & $15 \mathrm{~h} 54 \mathrm{~min}$ às $16 \mathrm{~h} 20 \mathrm{~min}$ \\
\hline \multicolumn{2}{|c|}{ Pesquisadora: Lídia Godoi } \\
\hline \multicolumn{2}{|c|}{ Professoras envolvidas: $\mathrm{O}$ e I. } \\
\hline \multicolumn{2}{|c|}{ Turma: MGI-AB } \\
\hline $\begin{array}{l}\text { Crianças pr } \\
\text { Duda, Viníci }\end{array}$ & $\begin{array}{l}\text { entes: Jorge, Thiago, Vinícius, Matheus, Yasmin, Henrique, Sarah, José, } \\
\text { s, Ingrid, Eduardo, Luiz, Jeferson, Lara, Marcos, Vitor (total de } 17 \text { crianças). }\end{array}$ \\
\hline
\end{tabular}




\begin{tabular}{|l|l|}
\hline Natureza da atividade e materiais & Brincar livre no solário. \\
\hline $\begin{array}{l}\text { Participação das crianças e produções } \\
\text { coletivas e individuais }\end{array}$ & Todas as crianças participam. \\
\hline $\begin{array}{l}\text { Comunicação: Adulto-criança / } \\
\text { criança-criança }\end{array}$ & $\begin{array}{l}\text { Adulto-criança: acontece somente nos momentos } \\
\text { em que as crianças solicitam algum auxílio. } \\
\text { Criança-criança: constante por meio de gestos e } \\
\text { da fala. }\end{array}$ \\
\hline $\begin{array}{l}\text { Acontecimentos planejados e } \\
\text { imprevistos }\end{array}$ & \\
\hline
\end{tabular}

\section{Relatório}

As crianças se dirigem ao solário, um espaço amplo, cercado por grades, que fica na parte superior do CEI. Lá, ficam disponíveis motocas e brinquedos como cavalinhos e escorregador.

Há, hoje, no solário, 10 gangorras individuais de cavalinhos, quatro gangorras maiores, sete motocas e um carrinho.

Luiz Gustavo, logo ao chegar, já vai organizando os cavalinhos, que são, na verdade, gangorras, um ao lado do outro.

Feito o percurso, Luiz começa a andar, equilibrando sobre os cavalos.

O desafio é andar sobre as gangorras de cavalinho, fazendo o percurso que conta com 10 cavalinhos.

As outras crianças logo entram na brincadeira.

Sarah, Vitor, Jeferson e Vivi estão fazendo o percurso.

Zé, ao passar pelos cavalinhos, escorrega e leva numa boa.

- UI!!

Luiz Gustavo solta um grito de felicidade ao terminar o percurso.

- Uhuu!

Maria Eduarda tenta um desafio maior: fazer o percurso com uma motoca na mão.

Ela anda três cavalinhos e desiste. Andar sobre os cavalinhos é um desafio motor enorme, pois exige equilíbrio.

Luiz, Jorge e Zé permanecem todo o tempo brincando no percurso criado por Luiz.

Jantar

\begin{tabular}{|c|c|}
\hline Data & $19 / 09 / 2013$ \\
\hline $\mathrm{N}^{\circ}$ registro & 08 \\
\hline Horário & $16 \mathrm{~h} 20 \mathrm{~min}$ às $16 \mathrm{~h} 50 \mathrm{~min}$ \\
\hline \multicolumn{2}{|c|}{ Pesquisadora: Lídia Godoi } \\
\hline \multicolumn{2}{|c|}{ Professoras envolvidas: $\mathrm{O}$ e I. } \\
\hline \multicolumn{2}{|c|}{ Turma: MGI-AB } \\
\hline $\begin{array}{l}\text { Crianças pr } \\
\text { Duda, Viníci }\end{array}$ & $\begin{array}{l}\text { sentes: Jorge, Thiago, Vinícius, Matheus, Yasmin, Henrique, Sarah, José, } \\
\text { s, Ingrid, Eduardo, Luiz, Jeferson, Lara, Marcos, Vitor (total de } 17 \text { crianças). }\end{array}$ \\
\hline
\end{tabular}




\begin{tabular}{|l|l|}
\hline Natureza da atividade e materiais & Jantar. \\
\hline $\begin{array}{l}\text { Participação das crianças e produções } \\
\text { coletivas e individuais }\end{array}$ & Todas as crianças participam. \\
\hline $\begin{array}{l}\text { Comunicação: Adulto-criança / } \\
\text { criança-criança }\end{array}$ & $\begin{array}{l}\text { Adulto-criança: bem presente. As professoras } \\
\text { auxiliam as crianças quando necessário e as } \\
\text { incentivam na alimentação. } \\
\text { Criança-criança: as crianças conversam entre si } \\
\text { constantemente também nos momentos de } \\
\text { higiene e alimentação. }\end{array}$ \\
\hline $\begin{array}{l}\text { Acontecimentos planejados e } \\
\text { imprevistos }\end{array}$ & \begin{tabular}{l} 
\\
\hline
\end{tabular}
\end{tabular}

\section{Relatório}

Hora de lavar as mãos para o jantar. Oacompanha as crianças ao banheiro enquanto I está no solário com parte da turma.

As crianças fazem suas necessidades e lavam suas mãos sozinhas. O está ali apenas para auxiliar se for preciso. Quando as crianças terminam de lavar, sentam-se em um banquinho que fica em frente ao banheiro esperando os demais.

Descemos para o jantar, as crianças pegam seus pratos e sentam-se à mesa em que costumam jantar todos os dias.

Jorge, Zé, Ingrid e Eduardo sentam-se juntos.

Zé pergunta a Luiz:

- Você é meu amigo?

Luiz faz um gesto sinalizando que sim.

Enquanto I os observa, O senta-se ao lado do Marcos.

O:

- Mastiga primeiro devagar. Marcos estava comendo muito rápido, parecia engolir o alimento. O continua orientando-o:

- Coloca na boca, mastiga devagar e depois engole. Não precisa ter pressa.

Ingrid, Zé, Jorge e Luiz conversam.

Ingrid diz com um sorriso;

- Eu sou amiga do Luiz Gustavo.

Ao terminar, as crianças vão até o lixo, limpam seus pratos e devolvem na janelinha da cozinha onde são servidas as refeições.

Jeferson mostra para $\mathrm{O}$ que já comeu tudo.

O:

- Muito bem, parabéns. Quer mais?

Ele responde que não. As professoras mostraram-se cuidadosas, observando e incentivando as crianças a comerem.

Após todos terminarem, I e O distribuem a sobremesa (banana). Elas mostram-se pacientes e deixam que as crianças descasquem sozinhas. Quando terminaram de comer a banana, foi oferecida água. As professoras serviram a água.

Ao terminar o jantar, as crianças vão para a sala escovar os dentes e se organizarem para ir embora. 


\section{Impressões gerais}

\section{9/09/2013 - IMPRESSÕES GERAIS - MANHÃ}

Nos momentos observados hoje pela manhã, foi possível perceber essa postura de respeito, cuidado, atenção e afeto das professoras em relação às crianças. Mesmo na situação adversa de estar sozinha, $\mathrm{P}$ se manteve sempre tranquila, organizando a rotina de forma que as crianças pudessem interagir com os colegas e realizar os cuidados com a higiene de forma autônoma.

No período da manhã, a rotina da turma contemplou momentos de acolhimento, higiene e alimentação, brincadeiras livres e atividade dirigida.

$\mathrm{P}$ tem uma postura não controladora, exalta as crianças e mantém uma relação afetuosa com elas. Ao se dirigir às crianças, agacha-se para estar na altura delas.

Percebe-se, em cada ação, uma intencionalidade pedagógica. Na chegada, $\mathrm{P}$ ensina-os a guardar seus pertences, auxiliando-os nesse momento. Para garantir esse auxílio e afeição às crianças que chegam, já que as recebe sozinha, montou uma área com jogos diferentes para que as crianças pudessem escolher.

Na hora de guardar, procurou possibilitar um exercício de classificação em que as crianças deveriam agrupar os jogos pelo modelo. Interagiu com a turma nesse momento, incentivando-os dando elogios etc.

No parque, as deixou brincar livremente sem interferências. Lá elas puderam escolher os colegas para brincar, interagir com outras turmas, definir com que objetos brincariam e em que local do espaço disponível seriam realizadas suas brincadeiras.

Não houve por parte de $\mathrm{P}$ palavras autoritárias, ou rudes, sua postura foi sempre muito afetuosa.

Percebi, também, que a professora procurou, na medida do possível, respeitar o tempo das crianças, sem apressá-las.

\section{9/09/2013 - IMPRESSÕES GERAIS - TARDE}

Percebi, nos momentos observados, uma concepção de criança ativa. Tanto nos momentos conduzidos como as rodas de conversa, assim como nos livres (cantinhos e solário). Há uma coerência no trato com as crianças em todos os momentos observados ao longo do dia. As professoras as escutam, conversam e dão importância e atenção às suas falas. As possibilidades de inter-relações foram muitas, sobretudo nas áreas de interesse e no solário. As interações foram contempladas desde o momento em que as crianças começam a acordar até a hora do jantar (período em que observei). A turma pôde fazer escolhas no momento de brincar livre (áreas de interesse e solário): escolheram em que áreas brincariam, com quais colegas, que materiais utilizar. No solário, tiveram liberdade para investir em suas brincadeiras sem intervenções adultas (embora essas estivessem atentas ao movimento das crianças).

Senti que a rotina é constituída na turma, tanto na manhã quanto à tarde, como um instrumento de autonomia. As crianças são, em boa parte do tempo, incentivadas a organizar o espaço, cuidar de si e de seus pertences, alimentar-se e fazer sua higiene sozinhas. As professoras assumem uma postura de auxiliar as crianças quando necessário. Sempre as ensinando como fazer.

Também procuram dinamizar os momentos de espera.Um exemplo é a ôlafeita nas escadas durante a tarde, enquanto as crianças esperam para ir para a sala. E de manhã as conversas ou canções cantadas pelas crianças e professores.

No horário das refeições, à tarde, as crianças pegam seus pratos (no jantar) e copos (no café da tarde) sozinhas. Depois se dirigem aos seus lugares. Pela manhã, ocorre diferente. As 
crianças sentam-se e esperam a professora entregar as refeições.

Hoje, as professoras da tarde, percebendo o desejo das crianças em falar do filme que assistiram pela manhã, engataram uma boa conversa com a turma a esse respeito. Isso mostra um respeito com a turma e com aquilo que lhes interessa.

$\mathrm{O}$ e I fariam, hoje, experiências dirigidas sobre a pesquisa sonora. Contudo, percebendo que as crianças preferiam brincar nas áreas de interesse, elas deixaram a pesquisa sonora para outro momento. Ao colocar a possibilidade de continuar um mesmo assunto com as crianças (caso do filme) depois do lanche, fica claro que o tempo das crianças é respeitado, ou seja, se precisam de mais tempo para conversar, elas terão.

Nos dois períodos, percebi uma preocupação visível em não apressá-las, sobretudo nos momentos de higiene e alimentação.

26/09/2013

Café da manhã

\begin{tabular}{|l|l|}
\hline Data & $26 / 09 / 2013$ \\
\hline No $^{\mathbf{0}}$ registro & 01 \\
\hline Horário & $08 \mathrm{~h} 00 \mathrm{~min}$ às 08h30min \\
\hline Pesquisadora: Lídia Godoi \\
\hline Professoras envolvidas: P e E. \\
\hline Turma: MGI-AB \\
\hline $\begin{array}{l}\text { Crianças presentes: Matheus N., Marcos, Sarah, Zé, Mathias, Vinícius, Duda, Ingrid, } \\
\text { Lara, Eduardo, Amanda, Jorge, Thiago, Yasmin, Luiz, Jeferson, Vitor, Dhara, Giovana } \\
\text { (total de } 19 \text { crianças). }\end{array}$ \\
\hline
\end{tabular}

\begin{tabular}{|l|l|}
\hline Natureza da atividade e materiais & Alimentação: café da manhã. \\
\hline $\begin{array}{l}\text { Participação das crianças e produções } \\
\text { coletivas e individuais }\end{array}$ & Todas as crianças participam. \\
\hline $\begin{array}{l}\text { Comunicação: Adulto-criança / } \\
\text { criança-criança }\end{array}$ & $\begin{array}{l}\text { Adulto-criança: ocorre sempre que as crianças } \\
\text { solicitam alguma ajuda. } \\
\text { Criança-criança: as crianças conversam bastante } \\
\text { entre si nesse momento. }\end{array}$ \\
\hline $\begin{array}{l}\text { Acontecimentos planejados e } \\
\text { imprevistos }\end{array}$ & \\
\hline
\end{tabular}




\section{Relatório}

As crianças chegam e sentam-se à mesa. A professora $\mathrm{E}$, que está substituindo $\mathrm{V}$, passa com a bandeja oferecendo pão e leite para a turma.

Mathias não quis, ele brinca com Thiago. $\mathrm{P}$ o chama atenção.

- Mathias, você quase derrubou o leite do seu amigo!

Marcos, Jorge e Jeferson brincam com os biscoitos fingindo ser um carro. P os observa. Na brincadeira, Marcos derruba o potinho de biscoito do Jorge.

- Vai lá, Marcos, pega outro pro seu amigo. Você derrubou o dele.

Marcos prontamente vai pegar. Sarah está subindo na mesa. E aproxima-se e diz:

- Senta direito, mocinha!

Sarah, Vitor e Matheus também estão conversando.

Vitor diz para Matheus:

- Eu sou um monstro...

Vitor bate as mãos sobre a mesa, ritmando um som.

As professoras deixam as crianças livres, elas ora comem, ora conversa, cantam. Não há pressa.

E considera que estava muito barulho no refeitório e pede silêncio.

- Gente, por favor, fala mais baixo está muito barulho.

Vitor e Matheus conversam sobre suas meias.

Matheus:

- Minha meia é de carrinho.

Vitor:

- A minha é do homem aranha.

P se aproxima e diz:

- Sua meia é do homem aranha. É igual a do Marcos.

Sem pressa, $\mathrm{P}$ espera o último terminar. O Jeferson.

- Pronto, todos terminaram?

- Não (percebo que Duda ainda come vagarosamente seu biscoito. Enquanto isso, a turma brinca com as mãos)

Zé está fazendo ôla com Ingrid e Dhara.

Jeferson, Vitor, Sarah e Marcos brincam de super-herói. Jeferson e Vitor atiram enquanto

Sarah e Marcos se escondem atrás da mesa.

P:

- Turminha, nós vamos subir um pouquinho. Se a professora estiver na sala, a gente espera.

Subimos para assistir ao filme.

Vídeo

\begin{tabular}{|l|l|}
\hline Data & $26 / 09 / 2013$ \\
\hline $\mathbf{N}^{\circ}$ registro & 02 \\
\hline Horário & 09h00min às 09h52min \\
\hline Pesquisadora: Lídia Godoi \\
\hline Professoras envolvidas: P e E. \\
\hline Turma: MGI-AB \\
\hline $\begin{array}{l}\text { Crianças presentes:Matheus N., Marcos, Sarah, Zé, Mathias, Vinícius, Duda, Ingrid, Lara, } \\
\text { Eduardo, Amanda, Jorge, Thiago, Yasmin, Luiz, Jeferson, Vitor, Dhara, Giovana (total de } \\
19 \text { crianças). }\end{array}$ \\
\hline
\end{tabular}




\begin{tabular}{|l|l|}
\hline Natureza da atividade e materiais & Atividade dirigida. \\
\hline $\begin{array}{l}\text { Participação das crianças e produções } \\
\text { coletivas e individuais }\end{array}$ & Todas as crianças participam. \\
\hline $\begin{array}{l}\text { Comunicação: Adulto-criança / } \\
\text { criança-criança }\end{array}$ & $\begin{array}{l}\text { Adulto-criança: pouca comunicação, somente } \\
\text { havia alguns comentários durante o filme. } \\
\text { Criança-criança: pouca, as crianças conversavam } \\
\text { entre si com menor frequência. }\end{array}$ \\
\hline $\begin{array}{l}\text { Acontecimentos planejados e } \\
\text { imprevistos }\end{array}$ & $\begin{array}{l}\text { Foi planejado pelas professoras assistir ao filme } \\
\text { "O mar não está para peixe". Tudo ocorreu como } \\
\text { planejado. }\end{array}$ \\
\hline
\end{tabular}

\section{Relatório}

No momento de espera até a hora do filme, P canta com as crianças.

"Para poder o frio esquentar, ponha seus cavalos todos a trotar..."

Cavalos trotando uma pata (repete a canção). Está canção envolve música e movimento. P:

- Hoje, nós vamos assistir ao filme “O mar não está pra peixe”, só uma parte, continuamos o restante na semana que vem.

$\mathrm{Na}$ sala de vídeo, as crianças sentam-se no tapete. Enquanto as professoras organizam o vídeo, as crianças conversam.

Matheus fala para Zé:

- Olha o tubarão! Você tem medo?

Sarah:

- É monte de peixes.

Yasmin:

- É o peixe. É o meu peixe.

O filme trata da mesma temática do projeto em que as crianças estão trabalhando, que trata, sobretudo, dos peixes.

P aproveita esse momento para colocar as agendas em ordem. Sem nenhum tipo de coerção, as crianças assistem ao filme atentas.

Yasmin conta os peixes que aparecem no vídeo.

$-1,2,3,4 \ldots$

Nos momentos amedrontadores do filme, as crianças se manifestam com gestos e fala.

Vinícius coloca a mão sobre os olhos.

Vitor:

- O tubarão. Que medo!

Sarah:

- Ele perdeu a mãe dele. E o pai também.

Marcos:

- Acho que ele morreu.

Luiz:

- A chuva. 
Yasmin:

- O peixe tem que pegar o guarda-chuva.

Duda:

- É tubarão! (ao ver o tubarão)

Mathias:

- Não! É baleia.

Percebo que as crianças reconhecem e nomeiam os peixes.

Jorge, Lara e Jeferson conversam. Marcos vira para trás e diz:

- Silêncio!

Marcos:

- O peixe mora na água né, Vitor?

Mathias:

- É grande o tubarão.

A expressão facial das crianças muda a cada cena. Ora espanto, ora alegria.

Sarah e Matheus deitam-se no tapete.

$\mathrm{P}$ termina as agendas e senta-se no tapete com as crianças.

$\mathrm{P:}$

- Olha! Esse é o grande peixe azul.

Duda:

- É a tartaruga! (uma tartaruga aparece no filme)

Yasmin:

- P, eles são amigos.

$\mathrm{P}:$

- Olha o polvo também. Esse é o polvo.

P:

- Olha lá, gente, vai ter uma festa. Um show.

$\mathrm{P}$ assiste ao filme com as crianças, fazendo interferências quando considera necessário.

Apareceu no filme um camarão falante. $\mathrm{P}$ explica para as crianças:

- Esse é o camarão. Tá escuro, eles estão vendo as estrelas.

Nesse momento, uma cena do filme passa sem que as crianças compreendam o que foi dito. $P$ fala para a professora $E$ :

- Vai ter que voltar Paty. Não deu para eles escutarem.

Ao perceber que as crianças estão se dispersando, $\mathrm{P}$ resolve parar o filme para não ficar cansativo. Irão retomar próxima quinta.

Mathias:

- O tubarão quer casar com o peixe rosa.

Vitor:

- Ele vai morder.

Sarah:

- O tubarão não morde.

P:

- A Sarah está falando que o tubarão não morde. Será que ele morde? Acho que morde sim, ele tem os dentes afiados.

Vitor:

- O peixinho perdeu o pai dele. As crianças começam a correr pela sala, enquanto $\mathrm{P}$ retira o filme do reprodutor.

P diz:

- Não tem problema. Quem está conversando na sala vai ter de ficar sentando no parque.

Agora a turma irá fazer a higiene para tomar o suco.

$\mathrm{P}$ chama primeiro os que não estavam correndo. 
Enquanto E acompanha uma turma ao banheiro, a outra turma espera P no corredor, sentados no banquinho.

P os orienta:

- Pessoal, subam a manga da blusa para não molhar.

Thiago pega uma quantidade grande de papel. P observa e diz:

- Thiago tem muito papel.

Marcos deixa a torneira muito tempo ligada.

P:

- Marcos, chega de desperdiçar água.

Suco

\begin{tabular}{|l|l|}
\hline Data & $26 / 09 / 2013$ \\
\hline $\mathbf{N}^{\mathbf{0}}$ registro & 03 \\
\hline Horário & 09h55min às 10h05min \\
\hline Pesquisadora: Lídia Godoi \\
\hline Professoras envolvidas: P e E. \\
\hline Turma: MGI-AB \\
\hline $\begin{array}{l}\text { Crianças presentes: Matheus N., Marcos, Sarah, Zé, Mathias, Vinícius, Duda, Ingrid, } \\
\text { Lara, Eduardo, Amanda, Jorge, Thiago, Yasmin, Luiz, Jeferson, Vitor, Dhara, Giovana } \\
\text { (total de 19 crianças). }\end{array}$ \\
\hline
\end{tabular}

\begin{tabular}{|l|l|}
\hline Natureza da atividade e materiais & Alimentação (suco). \\
\hline $\begin{array}{l}\text { Participação das crianças e produções } \\
\text { coletivas e individuais }\end{array}$ & Todas as crianças participam. \\
\hline $\begin{array}{l}\text { Comunicação: Adulto-criança / } \\
\text { criança-criança }\end{array}$ & $\begin{array}{l}\text { Adulto-criança: a professora incentiva o tempo } \\
\text { todo as crianças a tomarem o suco. } \\
\text { Criança-criança: as crianças conversam pouco, } \\
\text { pois estão empenhadas em tomar todo o suco. }\end{array}$ \\
\hline $\begin{array}{l}\text { Acontecimentos planejados e } \\
\text { imprevistos }\end{array}$ & \begin{tabular}{l}
\hline \\
\hline
\end{tabular}
\end{tabular}

\section{Relatório}

As crianças sentam-se à mesa para tomar o suco. $\mathrm{P}$ distribui o suco para todas as crianças.

E:

- É suco de que, gente?

P:

- Eu acho que é suco de limão.

P:

- Quem vai querer participar da minha pirâmide? Só vale quem está de caneca vazia.

$\mathrm{P}$ faz isso para incentivá-los a tomar todo o suco. 
Ao terminar, as crianças levam os copos para compor a pirâmide.

P:

- O Zezinho conseguiu vir para a pirâmide! A Dhara também! O meu amigo Matheus também! Que grande minha pirâmide. Ela está muito alta.

E:

- A Sarah não conseguiu vir para a pirâmide.

P:

- Parabéns! Quem não conseguiu tenta na próxima vez, tá bom?

\begin{tabular}{|c|c|}
\hline & Almoço \\
\hline Data & $26 / 09 / 2013$ \\
\hline $\mathrm{N}^{0}$ registro & 04 \\
\hline Horário & $10 \mathrm{~h} 55 \mathrm{~min}$ às $11 \mathrm{~h} 25 \mathrm{~min}$ \\
\hline \multicolumn{2}{|c|}{ Pesquisadora: Lídia Godoi } \\
\hline \multicolumn{2}{|c|}{ Professoras envolvidas: $\mathrm{P}$ e E } \\
\hline \multicolumn{2}{|c|}{ Turma: MGI-AB } \\
\hline \multicolumn{2}{|c|}{$\begin{array}{l}\text { Crianças presentes: Matheus N., Marcos, Sarah, Zé, Mathias, Vinícius, Duda, Ingrid, } \\
\text { Lara, Eduardo, Amanda, Jorge, Thiago, Yasmin, Luiz, Jeferson, Vitor, Dhara, Giovana } \\
\text { (total de } 19 \text { crianças). }\end{array}$} \\
\hline
\end{tabular}

\begin{tabular}{|l|l|}
\hline Natureza da atividade e materiais & Alimentação (almoço). \\
\hline $\begin{array}{l}\text { Participação das crianças e produções } \\
\text { coletivas e individuais }\end{array}$ & Todas as crianças participam. \\
\hline $\begin{array}{l}\text { Comunicação: Adulto-criança / } \\
\text { criança-criança }\end{array}$ & $\begin{array}{l}\text { Adulto-criança: pouca comunicação. Somente } \\
\text { quando as crianças necessitam de alguma ajuda. } \\
\text { Criança-criança: as crianças conversam entre si, } \\
\text { contudo estão envolvidas com a alimentação. }\end{array}$ \\
\hline $\begin{array}{l}\text { Acontecimentos planejados e } \\
\text { imprevistos }\end{array}$ & \\
\hline
\end{tabular}

\section{Relatório}

P e E estão fazendo a higiene para o almoço. Ao terminar, seguimos para o refeitório. As crianças dirigem-se à janelinha onde são servidos os pratos, acredito que tenha sido porque, no período da tarde, elas pegam sozinhas os seus pratos.

P:

- Gente! Senta lá na mesa para almoçar.

As professoras distribuem os pratos. As crianças não fazem esse movimento de pegar sozinhas. Hoje tem arroz, feijão, salada e frango. O prato vem pronto.

Vinícius prova um pouquinho.

- Tá quente. 
As crianças estão envolvidas com o alimento. Não conversam muito.

Zé e Matheus estão chegando agora. Estavam lavando as mãos no banheiro.

E e P. estão por perto observando. As crianças comem sem a ajuda das professoras.

Vinícius alimenta-se sozinho. Prefere comer só arroz.

Duda derrama comida sobre a mesa.

P:

- Duda, presta atenção! Olha o que você está fazendo!

Sarah, Marcos, Vitor e Matheus jogam a comida no lixo sem interferência das professoras.

Matheus cospe na mesa.

E.:

- Para de cuspir, Matheus! Vou pegar um papel.

Vinícius jogou quase a comida toda no lixo.

As crianças comem pouco, jogam boa parte da comida no lixo.

E se aproxima de Jorge para auxiliar:

- Come mais um pouco, Jorge.

Matheus termina e vai pegar mais.

$\mathrm{AC}$ e P. não insistem com as crianças que não desejam comer, mas colocam em evidência os que comem tudo.

- Parabéns, Duda! Comeu tudo!

Não há pressa. As crianças alimentam-se em seu ritmo.

AC toma o cuidado de limpar o nariz das crianças durante a refeição. No refeitório, só se escutam as vozes das crianças. As professoras falam baixo, aproximam-se das crianças para falar.

A sobremesa é servida pelas professoras apenas para as crianças que querem.

E. para Zé:

- Você quer sobremesa, amor?

Zé aceita. A sobremesa é salada de frutas.

Enquanto esperam a água, as crianças começam uma batucada na mesa.

Zé ainda come lentamente a salada de frutas. Ao perceber $\mathrm{P}$ chamando as crianças para subir,ele joga o resto da salada no lixo.

São $11 \mathrm{~h} 25 \mathrm{~min}$. O almoço termina e as crianças sobem para fazer a higiene e repouso.

\section{Festinha}

\begin{tabular}{|l|l|}
\hline Data & $26 / 09 / 2013$ \\
\hline $\mathbf{N}^{\mathbf{o}}$ registro & 05 \\
\hline Horário & $15 \mathrm{~h} 50 \mathrm{~min}$ às 16h40min \\
\hline Pesquisadora: Lídia Godoi \\
\hline Professoras envolvidas: O e I \\
\hline Turma: MGI-AB \\
\hline $\begin{array}{l}\text { Crianças presentes: Matheus N., Marcos, Sarah, Zé, Mathias, Vinícius, Duda, Ingrid, } \\
\text { Lara, Eduardo, Amanda, Jorge, Thiago, Yasmin, Luiz, Jeferson, Vitor, Dhara, Giovana } \\
\text { (total de } 19 \text { crianças). }\end{array}$ \\
\hline
\end{tabular}




\begin{tabular}{|l|l|}
\hline Natureza da atividade e materiais & $\begin{array}{l}\text { Atividade esporádica (festa de aniversariantes do } \\
\text { mês). }\end{array}$ \\
\hline $\begin{array}{l}\text { Participação das crianças e produções } \\
\text { coletivas e individuais }\end{array}$ & Todas as crianças participam. \\
\hline $\begin{array}{l}\text { Comunicação: Adulto-criança / } \\
\text { criança-criança }\end{array}$ & $\begin{array}{l}\text { Adulto-criança: as professoras dançam com as } \\
\text { crianças, cantam, conversam, perguntam sobre o } \\
\text { que querem comer. } \\
\text { Criança-criança: as crianças cantam, dançam } \\
\text { juntas e conversam entre si. }\end{array}$ \\
\hline $\begin{array}{l}\text { Acontecimentos planejados e } \\
\text { imprevistos }\end{array}$ & \begin{tabular}{l}
\hline \\
\hline
\end{tabular}
\end{tabular}

\section{Relatório}

Hoje, a rotina é diferente por conta da festa dos aniversariantes do mês. Essa festa acontece todo final de mês. Tem uma festa para o piso superior e uma para o inferior. Comemora-se o aniversário dos meninos e meninas que completam ano naquele mês.

As professoras me explicam que nesse dia há mudança da rotina. Eles acordam, e por volta das $15 \mathrm{~h} 00 \mathrm{~min}$, eles iniciam a festa, com os comes e bebes. Como uma festa convencional, com bolo, refrigerante, doces, salgados e música. Os comes e bebes são preparados pela equipe da cozinha.

Todas as crianças do piso superior, MG e BII, participam. As turmas do piso inferior fazem sua festa no parque.

As crianças comem e bebem, e são servidos pelas professoras. Por enquanto, as crianças parecem só se interessar em comer.

$\mathrm{O}$ e I se ocupam em servi-los.

A festa é realizada na sala de MG. Ela é ampla e interligada com o solário, então as crianças podem ficar na sala e dançar ou podem brincar no solário.

Jorge e Matheus saem e vão brincar na gangorra com outras duas crianças do MG.

Ele se aproxima de mim e diz:

- Esse é meu amigo. Tira uma foto?

Fotografo os dois.

Vitor e Mathias brincam no cavalinho gangorra, parecem se divertir muito.

Mathias chega e finge-se de monstro:

- ARRRHH!! E começa a correr atrás das crianças.

De repente, a música na sala é trocada. "Show das poderosas". Vitor, Luiz e Mathias correm para dançar (vídeo). A dança com as crianças. Sarah, Luiz e Duda dançam juntos. Duda grita e canta com toda força. As crianças parecem se divertir muito. Hora de cantar parabéns. O se empenha na organização da turma. Só o Vinícius é aniversariante. Canta-se o parabéns.

O bolo é de cenoura com chocolate. Na parede, algumas bexigas e um letreiro escrito parabéns. As professoras distribuem o bolo para as crianças que querem.

As crianças sorriem, cantam, batem palmas. Estão felizes.

Algumas crianças recebem o bolo e se dirigem ao solário para comer: Mathias, Matheus, Dhara. Eles têm essa liberdade.

Henrique transita pela sala com o pratinho na mão. 
Após o bolo, a festa continua.

Duda:

- O, coloca "Lek, lek" (um funk da moda).

O coloca. Duda começa a dançar imitando dançarinas de funk.

A turma fica empolgada quando escuta as músicas que costuma ouvir fora do CEI. Em casa, na rua... Lara pede uma música:

- Show das poderosas.

Duda acompanha cantando e dançando.

\section{Roda de conversa}

\begin{tabular}{|l|l|}
\hline Data & $26 / 09 / 2013$ \\
\hline $\mathbf{N}^{\mathbf{0}}$ registro & 06 \\
\hline Horário & $16 \mathrm{~h} 50 \mathrm{~min}$ às 17h20min \\
\hline Pesquisadora: Lídia Godoi \\
\hline Professoras envolvidas: Oe I \\
\hline Turma: MGI-AB \\
\hline $\begin{array}{l}\text { Crianças presentes: Matheus N., Marcos, Sarah, Zé, Mathias, Vinícius, Duda, Ingrid, } \\
\text { Lara, Eduardo, Amanda, Jorge, Thiago, Yasmin, Luiz, Jeferson, Vitor, Dhara, Giovana } \\
\text { (total de 19 crianças). }\end{array}$ \\
\hline
\end{tabular}

\begin{tabular}{|l|l|}
\hline Natureza da atividade e materiais & Roda de conversa. Atividade permanente. \\
\hline $\begin{array}{l}\text { Participação das crianças e produções } \\
\text { coletivas e individuais }\end{array}$ & $\begin{array}{l}\text { Boa parte da turma participa, conversando com a } \\
\text { professora e com os colegas. }\end{array}$ \\
\hline $\begin{array}{l}\text { Comunicação: Adulto-criança / } \\
\text { criança-criança }\end{array}$ & $\begin{array}{l}\text { Adulto-criança: as professoras questionam as } \\
\text { crianças, os incitam a falar. } \\
\text { Criança-criança: as crianças contam umas as } \\
\text { outras suas preferências e experiências. }\end{array}$ \\
\hline $\begin{array}{l}\text { Acontecimentos planejados e } \\
\text { imprevistos }\end{array}$ & \\
\hline
\end{tabular}

\section{Relatório}

Roda de conversar após a festa.

O:

- Vocês gostaram da festa?

Duda:

- Eu gostei da música da Anita.

Sarah:

- Eu gostei da música do Naldo.

Vitor canta: 
- Cada vez eu quero mais...

Henrique:

- Eu gostei da música do lek, lek.

$\mathrm{O}$ :

- Mas ninguém gostou de comer o bolo? Só da música?

I:

- E o suco do que era?

Mathias:

- É de maracujá.

Giovanna:

- Era de maracujá.

$\mathrm{O}$ :

- Agora tá perto da hora de ir embora, a festinha foi bem legal. Da nossa sala tinha um tinha um aniversariante, quem era?

Sarah:

- Pro Vinícius e pros bebês.

Mathias:

- É porque eu comi o bolo.

Zé:

- Eu comi pão.

I:

- Do que era o bolo?

Eduardo:

- De chocolate.

Jorge:

- Era cenola.

I:

- Olha só, que tal a gente guardar os cadernos na mochila e colocar as blusas de frio?

Na sala tem um cartaz com os ajudantes do dia. Eles têm que tirar as mochilas do armário e deixar em local fácil para as demais crianças se organizarem. Os ajudantes de hoje: Lara, Jorge, Luiz, e Jeferson.

As crianças vão até a mesa onde estão as agendas, precisam fazer o reconhecimento das suas e em seguida guardar na mochila. Essa organização as crianças fazem sozinhas, as professoras somente os auxiliam.

Enquanto esperam as famílias, as professoras colocam músicas para as crianças dançarem.

De repente, as crianças brincam de luta.

Acho melhor tirar a música, eles não estão mais dançando.

I:

- É, tão brincando de luta. Peraí que agora vocês vão brincar de luta.

Andreé:

- Se prepara, Lídia, a I vai lutar com eles.

I e $\mathrm{O}$ vão para o tapete e brincam de luta com a turma. Eles ficam em polvorosa, riem e se divertem muito.

I:

- Não tem jeito. Quando eles começam a gente tem que brincar.

$\mathrm{O}$ :

- Toda vez que $\mathrm{V}$ e $\mathrm{P}$ reclamam que as crianças brincam de luta, a gente fala que a gente aproveita para brincar de luta com eles também (vídeo). 
Brincar livre no solário

\begin{tabular}{|l|l|}
\hline Data & $26 / 09 / 2013$ \\
\hline $\mathbf{N}^{\mathbf{0}}$ registro & 07 \\
\hline Horário & $17 \mathrm{~h} 20 \mathrm{~min}$ às $17 \mathrm{~h} 45 \mathrm{~min}$ \\
\hline Pesquisadora: Lídia Godoi \\
\hline Professoras envolvidas: O e I. \\
\hline Turma: MGI-AB \\
\hline $\begin{array}{l}\text { Crianças presentes: Matheus N., Marcos, Sarah, Zé, Mathias, Vinícius, Duda, Ingrid, } \\
\text { Lara, Eduardo, Amanda, Jorge, Thiago, Yasmin, Luiz, Jeferson, Vitor, Dhara, Giovana } \\
\text { (total de } 19 \text { crianças). }\end{array}$ \\
\hline
\end{tabular}

\begin{tabular}{|l|l|}
\hline Natureza da atividade e materiais & Saída das crianças. \\
\hline $\begin{array}{l}\text { Participação das crianças e produções } \\
\text { coletivas e individuais }\end{array}$ & Todas as crianças participam. \\
\hline $\begin{array}{l}\text { Comunicação: Adulto-criança / } \\
\text { criança-criança }\end{array}$ & $\begin{array}{l}\text { Adulto-criança: as professoras conversam com } \\
\text { as crianças e com as famílias. } \\
\text { Criança-criança: as crianças conversam entre si } \\
\text { enquanto esperam. }\end{array}$ \\
\hline $\begin{array}{l}\text { Acontecimentos planejados e } \\
\text { imprevistos }\end{array}$ & \begin{tabular}{l}
\hline \\
\hline
\end{tabular}
\end{tabular}

\section{Relatório}

Hora de ir embora. Primeiro vão os de perua.

Chega o pai de Giovana:

- Opa, tá tudo escuro aí.

$\mathrm{O}$ :

- É que a gente tava brincando de lutinha. Aí colocamos essa música para acalmar eles.

A mãe de Jeferson chega e diz:

- O que tá acontecendo?

O explica.

- É que nós estávamos brincando de lutinha. Daí agora colocamos a música para acalmar.

A mãe do Jeferson chega. A diz:

- Conta pra mãe que vocês tiveram festa hoje.

Mãe do Jeferson:

- Festa? Que legal! Tchau, meninas, bom descanso.

A relação das professoras com os pais é bem amigável.

A avó do Vinícius chega.

$\mathrm{O}$ :

- A gente cantou parabéns pro Vini hoje.

Vinícius:

- Tive bolo. 
Vó:

- Que bom, meu amor.

O e I explicam na porta da reposição do dia seguinte.

O pai de Mathias chega. Mathias já foi logo dizendo:

- Teve festa.

O:

- Hoje, o Mathias veio me contar que fez xixi no vaso. Eu disse que "só falta fazer na sua casa né, Mathias?" Ele disse na maior cara de pau: “É!”. Ambos sorriram.

\section{Impressões gerais}

\section{6/09/2013 - IMPRESSÕES GERAIS - MANHÃ}

Nas observações de hoje, procurei acompanhar com mais atenção também os momentos de higiene e alimentação. Percebi um cuidado das professoras em ensinar para as crianças práticas como não desperdiçar água e papel, por exemplo. Esse cuidado que as professoras têm em acompanhar atentamente os momentos de higiene e alimentação, interferindo quando necessário, pode significar um entendimento de que todos os momentos vividos pelas crianças no CEI são educativos à medida que os meninos e meninas estão constantemente aprendendo na interação com os adultos, com as outras crianças e com o meio.

Durante o filme, foi possível perceber, pela fala das crianças, o quanto já aprenderam sobre os peixes e também o quanto essa temática está presente entre eles. P procurou interagir durante o filme, trazendo informações adicionais para a turma. Teve a sensibilidade de perceber o tempo das crianças. Ou seja, quando notou que o filme já não interessava, ela, de pronto, sugeriu fazer outra coisa, deixando para continuar com o filme na semana seguinte. Nesse momento, o tempo que comandou a ação foi o tempo das crianças e não o tempo do adulto.

\section{6/09/2013 - IMPRESSÕES GERAIS - TARDE}

Durante a tarde, centrei minhas atenções principalmente no horário da saída. Queria perceber como as professoras organizam o momento da saída e as interações com as famílias. Achei fantástico as professoras perceberem que as crianças queriam brincar de luta e se aventurarem nessa brincadeira também. Percebi que elas estão atentas e compreendem que as crianças comunicam-se também com o corpo. Atentar para as diferentes linguagens que meninos e meninas usam para se comunicar e, para além disso, brincar junto, demonstra um respeito para com as crianças e sua cultura. Ao perceber que os pequenos queriam brincar de luta, as professoras não cercearam o momento por medo de que essa brincadeira incitasse a violência, de maneira que o que prevaleceu foi a brincadeira proposta pelas crianças, que pareciam muito felizes naquele momento. $\mathrm{O}$ momento dessa interação por meio da brincadeira, mais uma vez, fez transparecer a relação de afeto que está bem presente entre as crianças e as professoras.

A comunicação com os pais me pareceu bastante amigável e respeitosa. A troca de informações sobre os momentos que acontecem na instituição e em casa ocorre de forma espontânea. Parece ser uma prática das professoras dizer para as famílias coisas que considerem interessantes de serem ditas sobre o dia da criança no CEI.

(Há uma filmagem da brincadeira de luta a que me refiro) 
$02 / 10 / 2013$

Brincar livre no parque

\begin{tabular}{|l|l|}
\hline Data & $02 / 10 / 2013$ \\
\hline $\mathbf{N}^{\mathbf{0}}$ registro & 01 \\
\hline Horário & 09h10min às 09h47min \\
\hline Pesquisadora: Lídia Godoi \\
\hline Professoras envolvidas: P e E \\
\hline Turma: MGI-AB \\
\hline $\begin{array}{l}\text { Crianças presentes: Mathias, Thiago, Amanda, Matheus N., Viviany, Yasmin, Henrique, } \\
\text { Sarah, José, Maria Eduarda, Dhara, Mateus, Vinícius, Jorge, Ingrid, Luiz, Jeferson, Lara, } \\
\text { Marcos, Vitor (total de } 19 \text { crianças). }\end{array}$ \\
\hline
\end{tabular}

\begin{tabular}{|l|l|}
\hline Natureza da atividade e materiais & Brincar livre, atividade permanente. \\
\hline $\begin{array}{l}\text { Participação das crianças e produções } \\
\text { coletivas e individuais }\end{array}$ & Todas as crianças participam. \\
\hline $\begin{array}{l}\text { Comunicação: Adulto-criança / } \\
\text { criança-criança }\end{array}$ & $\begin{array}{l}\text { Adulto-criança: ocorre sempre que as crianças } \\
\text { solicitam alguma ajuda. } \\
\text { Criança-criança: as crianças conversam, } \\
\text { organizam brincadeiras, brincam juntas. }\end{array}$ \\
\hline $\begin{array}{l}\text { Acontecimentos planejados e } \\
\text { imprevistos }\end{array}$ & \\
\hline
\end{tabular}

\section{Relatório}

Hoje, foquei nas atividades dirigidas e no brincar livre.

As professoras convidam as crianças para brincar no parque. O parque da instituição é um espaço amplo. Possui uma área coberta, com brinquedos como escorrega de concreto, balanças, casinha do Tarzan, tanque de areia, em uma parte. Na outra parte, há uma área coberta com uma caixa grande de plástico, toda perfurada, onde estão pazinhas, baldes, peneiras e moldes para brincar na areia. Há também uma parede de azulejo para pintar e uma pia na altura das crianças com torneiras e água à disposição. Bem perto da pia, uma mesa com cadeirinhas. A área coberta não é cercada, lá ficam disponíveis também motocas e triciclos de vários modelos. Nesse cenário, começo a observar as crianças que brincavam livremente sem intervenções dos adultos.

Aproximo-me de Duda, Dhara, Ingrid e Sarah, que estão brincando no parque.

Duda está com alguns baldinhos de água e lama.

Pergunto:

- Duda, o que você está fazendo?

Duda: 
- Tô fazendo um bolo.

Sarah:

- Eu tô brincando de cachorrinho (mesma brincadeira de duas semanas atrás)

Sarah e Ingrid se afastam e vão para outro canto. Vou atrás para observar a brincadeira delas.

Ingrid:

- Esse é meu cachorrinho.

Pergunto:

- Qual o nome desse cachorrinho?

Ingrid:

- Não sei. Não tem nome. É Sarah. Ele come a reação.

Sarah permanecer sentada (como cachorrinho). Ingrid percebe que estou fazendo anotações. Aproxima-se de mim e vem dizer o que está fazendo:

- A gente vai passear. Olha o porquinho dela (me mostra o porquinho de brinquedo).

Sarah deita-se no colo de Ingrid, que a acaricia como se fosse um bichinho.

Ingrid pega algumas pás e um copinho.

- Tô me maquiando. Vou maquiar o cachorrinho para passear.

Sarah vai atrás de Ingrid, andando normalmente e não como cachorrinho.

Elas vão para o outro lado do parque. Encontram Vitor.

Estão brincando de bebezinho.

Os bebês são peneiras da terra e os bonecos são aqueles moldes de fazer marcas na areia.

Ingrid abraça faz carinho e beija o bebê. Vitor se aproxima com seu boneco (molde de elefante) e diz:

- Ingrid, eu tenho um bebê! Ele domi no beço.

Ingrid:

- Yasmin, cuida do meu bebê. Só poquinho. Vou passear com o cachorrinho.

Sarah volta a ser o cachorrinho da Ingrid. Yasmin segura o "bebê" da Ingrid um pouquinho, mas logo desiste.

Ingrid e Sarah andam pelo parque.

Dhara chega de repente e me diz:

- Olha o bolo!

Pergunto onde.

Vivi, Sarah, Dhara, Jeferson, Mathias, Yasmin e Luiz vêm correndo.

Vivi:

- Corre! O lobo.

O lobo é o Marcos.

Ele faz gestos (imitando um lobo) e corre de um gradil a outro do parque atrás de Sarah, Yasmin, Dhara, Jorge, Amanda e Luiz.

Eles parecem se divertir muito.

Não há interferência das professoras E e P.

As crianças permanecem nesse movimento uns 7 minutos e param para andar no triciclo.

Observo Ingrid e Mathias criarem uma brincadeira. Eles pegam cada um uma pá de mexer com areia e uma peneira. $\mathrm{O}$ jogo imita o jogo de tênis, em que as pás são as raquetes e a peneira a bola. Eles brincam juntos por alguns minutos.

Durante todo o tempo que ficamos no parque, percebi que Vinícius não brincou com ninguém, ficou sentado atrás de uma lixeira grande no parque.

Hora de lavar as mãos para tomar suco.

E:

- Gente, vamos!

As crianças ajudam a guardar os brinquedos e vão entrando. 
Salas-ambiente

\begin{tabular}{|l|l|}
\hline Data & $02 / 10 / 2013$ \\
\hline No $^{\circ}$ registro & 02 \\
\hline Horário & $09 \mathrm{~h} 55 \mathrm{~min}$ às $10 \mathrm{~h} 45 \mathrm{~min}$ \\
\hline Pesquisadora: Lídia Godoi \\
\hline Professoras envolvidas: E e P. \\
\hline Turma: MGI-AB \\
\hline $\begin{array}{l}\text { Crianças presentes: Mathias, Thiago, Amanda, Matheus N., Viviany, Yasmin, Henrique, } \\
\text { Sarah, José, Maria Eduarda, Dhara, Mateus, Vinícius, Jorge, Ingrid, Luiz, Jeferson, Lara, } \\
\text { Marcos, Vitor (total de } 19 \text { crianças). }\end{array}$ \\
\hline
\end{tabular}

\begin{tabular}{|l|l|}
\hline Natureza da atividade e materiais & $\begin{array}{l}\text { Salas ambientes /Atividade permanente / Papel, } \\
\text { carimbos e carimbeiras. }\end{array}$ \\
\hline $\begin{array}{l}\text { Participação das crianças e produções } \\
\text { coletivas e individuais }\end{array}$ & Todas as crianças participam. \\
\hline $\begin{array}{l}\text { Comunicação: Adulto-criança / } \\
\text { criança-criança }\end{array}$ & $\begin{array}{l}\text { Adulto-criança: as professoras orientam as } \\
\text { crianças, estão sempre por perto observando, } \\
\text { auxiliando quando necessário. } \\
\text { Criança-criança: as crianças conversaram pouco } \\
\text { entre si, houve um grande envolvimento coma } \\
\text { atividade proposta (carimbar). }\end{array}$ \\
\hline $\begin{array}{l}\text { Acontecimentos planejados e } \\
\text { imprevistos }\end{array}$ & Tudo ocorreu conforme planejado. \\
\hline
\end{tabular}

\section{Relatório}

Após tomar o suco, as crianças esperam no corredor até que todas as turmas cheguem. Havia, em cada sala, uma área montada para exploração das crianças. A impossibilidade de acompanhar a turma em todas as áreas me fez optar pela área que E e P. haviam organizado. Era a área dos carimbos. Organizada no lactário. Um espaço com mesas e bancos (como o refeitório). A mesa está coberta com papel craft, carimbeiras e carimbos.

As crianças ficam livres para utilizá-los como quiser.

Luiz está concentrado, explorando os carimbos com impressão de animais.

Chegam Yasmin e Jorge. Yasmin carimba uma única vez e já sai do espaço.

Jorge e Luiz não falam nada. Só permanecem carimbando.

Lara chega para brincar.

E:

- Lara, sobe a manga da blusa pra não sujar.

Vivi acabou de chegar, ela olha o carimbo passa na carimbeira e começa a imprimir as marcas.

Vivi seleciona o desenho que quer carimbar. 
As crianças quase não conversam entre si, somente carimbam.

Luiz fica procurando um espaço ainda não carimbado para fazer as marcas.

Matheus N. chega à área do carimbo.

P:

- Senta lá atrás que tem bastante espaço.

E. mostra para Vivi como faz:

- Passa na carimbeira e aperta assim.

Matheus pega o carimbo e concentra-se carimbando entre os dedos.

$\mathrm{P}$ só faz interferências quando as crianças solicitam.

$\mathrm{P:}$

- Luiz você gostou, hein! Aqui já está sem espaço tem que explorar aquele espaço de lá (a outra mesa).

P senta-se junto com as crianças.

Luiz para P:

- Esse é o cachorro.

P:

- E esse? Peru, glu, glu, glu...

Vivi fez carimbos também pelo corpo.

Matheus voltou para os carimbos.

Luiz está limpando as mãos com o lencinho.

Matheus organiza os carimbos um ao lado do outro. Vivi passa os carimbos sobre a mesa.

Matheus continua concentrado enfileirando os carimbos.

P:

- Turminha! Agora vocês vão me ajudar a guardar os carimbos.

O Luiz dá uma última carimbada e guarda.

P:

- Nossa! Olha essa pequenininha como guarda. Vou dar lencinhos pra vocês limparem as mãos. Depois vai lavar lá no banheiro.

\section{Brincar livre no parque}

\begin{tabular}{|l|l|}
\hline Data & $02 / 10 / 2013$ \\
\hline $\mathbf{N}^{\mathbf{0}}$ registro & 03 \\
\hline Horário & $15 \mathrm{~h} 10 \mathrm{~min}$ às $15 \mathrm{~h} 45 \mathrm{~min}$ \\
\hline Pesquisadora: Lídia Godoi \\
\hline Professoras envolvidas: O e I. \\
\hline Turma: MGI-AB \\
\hline $\begin{array}{l}\text { Crianças presentes: Mathias, Thiago, Amanda, Matheus N., Viviany, Yasmin, Henrique, } \\
\text { Sarah, José, Maria Eduarda, Dhara, Mateus, Vinícius, Jorge, Ingrid, Luiz, Jeferson, Lara, } \\
\text { Marcos, Vitor (total de } 19 \text { crianças). }\end{array}$ \\
\hline
\end{tabular}

\begin{tabular}{|l|l|}
\hline Natureza da atividade e materiais & Brincar livre no parque / Atividade permanente. \\
\hline Participação das crianças e produções & Todas as crianças participam. \\
\hline
\end{tabular}




\begin{tabular}{|l|l|}
\hline coletivas e individuais & \\
\hline $\begin{array}{l}\text { Comunicação: Adulto-criança / } \\
\text { criança-criança }\end{array}$ & $\begin{array}{l}\text { Adulto-criança: as professoras auxiliam as } \\
\text { crianças quando necessário. } \\
\text { Criança-criança: as crianças conversam entre si, } \\
\text { se organizam para brincar e criam suas } \\
\text { brincadeiras. }\end{array}$ \\
\hline $\begin{array}{l}\text { Acontecimentos planejados e } \\
\text { imprevistos }\end{array}$ & Não houve planejamento prévio. \\
\hline
\end{tabular}

\section{Relatório}

A me explica que hoje elas iriam fazer o desenho ao som de diferentes ritmos, mas como não deu tempo de preparar as músicas, elas farão somente amanhã. Ela diz que como hoje tem sol, a prioridade é o parque, "Quando não chove, temos que sair com as crianças para sair com pouco da sala, já que essa semana eles ficaram muito confinados".

No parque, Ingrid e Lara brincam de maquiar. Elas pegam os objetos de brincar na areia, pás, moldes, baldes, e fazem de conta que estão maquiando uma a outra.

Lara:

- Tô passando batom.

Aproximo-me de Dhara e Ingrid, que estão brincando perto do gradil do parque.

Ingrid:

- A gente tá brincando de salão de beleza.

Pergunto o que elas estão usando para maquiar.

Sarah se aproxima andando de joelhos.

Dhara pergunta:

- Quer brincar cachorro? (brincadeira que realizaram também pela manhã)

Elas se dirigem para outro canto do parque e levam os brinquedos. Sarah se afasta. Ingrid e Dhara continuam brincando juntas.

Marcos, Jorge, Vitor, Thiago e Duda preferem fazer um percurso com as motocas.

Lara, Vivi, Vinícius e Jeferson tentam girar o bambolê.

Vivi chega perto do local que estou e diz:

- Minha mãe faz assim! (girando o bambolê)

Vitor para o triciclo do meu lado e diz:

- Ó, tem duas facas. (mostrando duas pás).

Pergunto:

- O que você vai fazer com as facas?

Vitor:

- Cota o bolo (pega a carroceria de um caminhãozinho de brinquedo e canta parabéns - a carroceria é o bolo).

Vitor:

- Sopa a vela, Thiago.

Vitor:

- Vô fazer um bolo.

Pergunto:

- O que você vai usar pra fazer o bolo?

Vitor:

- Ovo, e isso (faz movimentos como se estivesse fazendo uma mistura no baldinho utilizando pás). 
A percebe o movimento das crianças com o bambolê e entra na brincadeira.

Vivi observa como ela faz e tenta fazer igual. A coloca alguns bambolês no chão e faz uma pequena trilha. Mostra para as crianças como fazer.

- Pula assim! E de um pé só isso! Quem consegue fazer?

Mathias anda no triciclo com toda velocidade. Lara continua concentrada tentando girar o bambolê na cintura.

Vitor se aproxima com baldinhos e pás.

- Agora vou fazer um bolo pro Marcos.

Ao perceber que as pazinhas são rosa, Vivi toma uma da mão de Vitor e diz:

- Essa é de menina!

Observo de longe que Ingrid e Dhara continuam brincando juntas com os baldinhos, moldes e pás, e me aproximo.

Ingrid:

- A gente tamo brincando de comidinha.

Ingrid e Dhara:

- Advinha o que é isso? (mostrando o pedaço de um brinquinho de plástico).

Dhara fala algo que não consigo compreender.

Ingrid:

- É pantufa.

Ingrid pergunta pra mim:

- Quer brincar com a gente?

Digo que sim.

Ingrid:

- Tó sua comida.

Digo:

- Obrigada. O que tem aqui?

Ingrid:

- Sopa de feijão. Come tudo?

Respondo:

- Sim! O que tem de sobremesa?

Ingrid:

- Nescau (ela me da algo que parece um copo)

Comento:

- Tava uma delícia.

I chama as crianças:

- Pessoal, vamos.

$\mathrm{O}$ :

- Quem está com os potinhos guarda. Vamos lá para o solário. A turma guarda todo o material que utiliza (como de manhã).

Brincar livre no solário

\begin{tabular}{|l|l|}
\hline Data & $02 / 10 / 2013$ \\
\hline $\mathbf{N}^{\mathbf{0}}$ registro & 04 \\
\hline Horário & $15 \mathrm{~h} 55 \mathrm{~min}$ às $16 \mathrm{~h} 25 \mathrm{~min}$ \\
\hline Pesquisadora: Lídia Godoi \\
\hline Professoras envolvidas: O e I \\
\hline
\end{tabular}




\section{Turma: MGI-AB}

Crianças presentes: Mathias, Thiago, Amanda, Matheus N., Viviany, Yasmin, Henrique, Sarah, José, Maria Eduarda, Dhara, Mateus, Vinícius, Jorge, Ingrid, Luiz, Jeferson, Lara, Marcos, Vitor (total de 19 crianças).

\begin{tabular}{|l|l|}
\hline Natureza da atividade e materiais & Brincar livre no solário. \\
\hline $\begin{array}{l}\text { Participação das crianças e produções } \\
\text { coletivas e individuais }\end{array}$ & Todas as crianças participam. \\
\hline $\begin{array}{l}\text { Comunicação: Adulto-criança / } \\
\text { criança-criança }\end{array}$ & $\begin{array}{l}\text { Adulto-criança: as professoras auxiliam as } \\
\text { crianças quando necessário, interagem nas } \\
\text { brincadeiras quando são convidadas. } \\
\text { Criança-criança: as crianças conversam entre si, } \\
\text { se organizam para brincar e criam suas } \\
\text { brincadeiras. }\end{array}$ \\
\hline $\begin{array}{l}\text { Acontecimentos planejados e } \\
\text { imprevistos }\end{array}$ & Não houve planejamento prévio. \\
\hline
\end{tabular}

\section{Relatório}

A turma terá de ir para solário, porque os funcionários da limpeza irão lavar a sala. Não estava prevista a lavagem da sala, mas as professoras permitiram para colaborar. Hoje, era outra sala que seria lavada, mas como o berçário iria usar o solário, não deu. Todos os materiais das áreas de interesse que são montadas na sala estavam lá. Tesouras, papéis, lápis de cera, tinta, bonecas, enfim, todos os materiais que compõem os cantinhos da sala.Não era momento de utilizar as tintas, contudo, as crianças pegaram. Nem se importaram com os cavalinhos e o escorrega que estavam no solário, preferiram brincar com os objetos dos cantinhos. Criaram eles próprios áreas de interesse no solário.

Vivi, Sarah e Duda pegam giz e umas folhas grandes. Elas fazem desenhos e depois recortam.

Ingrid, Amanda e Willian brincam na soverteria. Thiago, Matheus, Luiz e Mathias brincam do jogo que inventaram com os pinos e a bola de boliche.

É interessante como as crianças utilizam os materiais dos cantinhos como se eles estivessem organizados na sala.

No jogo do "futeliche" (dei esse nome para o jogo dos meninos), Jorge entra e tenta pegar a bola com as mãos.

I:

- Bola no chão. Se pegar com a mão é falta.

Aparece a funcionária da limpeza que esta lavando a sala. Quando ela vê as crianças recortando papel no solário, ela diz:

- Vocês vão limpar tudo! Tudo!

$\mathrm{O}$ :

- É um incentivo para a senhora lavar o solário.

Sarah está desenhando faz um tempão, desde que chegamos ao solário. Sarah recorta o 
desenho.

- O que você desenhou Sarah?

Ela responde:

- Meu pai.

I e $\mathrm{O}$ brincam com as crianças na soverteria.

Amanda pega um cachorro-quente e oferece à A.

O pega, finge comer e diz:

- UMM!! Que delícia.

Hora de organizar tudo para lavar as mãos e jantar.

O:

- Pessoal, vamos organizar os brinquedos.

Hora de entrar para lavar as mãos e jantar.

\section{Impressões gerais}

\section{2/10/2013 - IMPRESSÕES GERAIS - MANHÃ}

As salas ambientes são um momento em que as crianças podem escolher colegas, espaços e materiais para brincar e explorar livremente. Embora atentas, as professoras deixam as crianças livres para transitar pelos espaços. Em alguns momentos, interagem brincando junto e encorajando as crianças em suas investidas. No parque, o que prevalece é a organização das próprias crianças para brincar. Elas escolhem os espaços, os materiais, inventam suas brincadeiras, e as professoras somente interferem quando as crianças solicitam algo.

\section{2/10/2013 - IMPRESSÕES GERAIS - TARDE}

As professoras mudam o planejamento em função das crianças. Isso é bem bacana e fica visível quando decidem ir ao parque ainda que estivesse preparada uma experiência na sala, visto que os outros dias foram chuvosos e as crianças pouco brincaram ao ar livre.

Outro fator foi o improviso. Utilizaram áreas de interesse no solário para que a sala fosse limpa. Tiveram de improvisar, pois não foram avisadas com antecedência sobre a limpeza da sala naquele dia.

$10 / 10 / 2013$

Café e roda de conversa

\begin{tabular}{|l|l|}
\hline Data & $10 / 10 / 2013$ \\
\hline $\mathbf{N}^{\mathbf{o}}$ registro & 01 \\
\hline Horário & 08h45min às $09 \mathrm{~h} 40 \mathrm{~min}$ \\
\hline Pesquisadora: Lídia Godoi \\
\hline
\end{tabular}




\section{Professoras envolvidas: E e P.}

Turma: MGI-AB

Crianças presentes: Matheus N., Marcos, Sarah, Zé, Mathias, Vinícius, Duda, Ingrid, Lara, Eduardo, Amanda, Jorge, Thiago, Yasmin, Luiz, Jeferson, Vitor, Dhara, Giovana (total de 19 crianças).

\begin{tabular}{|l|l|}
\hline Natureza da atividade e materiais & $\begin{array}{l}\text { Alimentação: café / atividade dirigida / roda de } \\
\text { conversa }\end{array}$ \\
\hline $\begin{array}{l}\text { Participação das crianças e produções } \\
\text { coletivas e individuais }\end{array}$ & Todas as crianças participam. \\
\hline $\begin{array}{l}\text { Comunicação: Adulto-criança / } \\
\text { criança-criança }\end{array}$ & $\begin{array}{l}\text { Adulto-criança: durante o café, as professoras } \\
\text { auxiliam as crianças na hora de se servirem. } \\
\text { Na roda, o diálogo acontece entre as professoras } \\
\text { que fazem questionamentos às crianças a } \\
\text { respeito do café da manhã. } \\
\text { Criança-criança: As crianças conversam bastante } \\
\text { entre si nesse momento do café. Durante a roda, } \\
\text { as crianças conversam com as professoras e } \\
\text { entre si também. }\end{array}$ \\
\hline $\begin{array}{l}\text { Acontecimentos planejados e } \\
\text { imprevistos }\end{array}$ & $\begin{array}{l}\text { O café da manhã ocorreu conforme o planejado. } \\
\text { Para o momento da roda, não houve um } \\
\text { planejamento prévio. }\end{array}$ \\
\hline
\end{tabular}

\section{Relatório}

Cheguei ao CEI hoje, e já me impactou a entrada. Havia trados coloridos e bexigas penduradas na entrada do CEI, e também um cartaz com os dizeres:

“Como esta é a semana da criança, está havendo no CEI uma programação especial". Hoje, por exemplo, no café, houve self-service. Uma mesa fria montada com queijo, presunto, tomate, alface, maionese e pão de forma. As crianças serviram-se e montaram seus lanches à vontade, alguns adultos usaram perucas coloridas e vestiram-se de palhaços. Na hora de montar o sanduíche, as professoras auxiliaram as crianças. Elas tinham liberdade de escolher os alimentos que iam compor o sanduíche'.

Roda da conversa.

E:

- O Jorge que lindo, comeu tudo.

$P$ :

- O Mathias precisa tomar cuidado com o leite. Todo dia ele derrama leite.

P fala com voz mais firme:

- A Maria Eduarda não para quieta na cadeira. A gente tem um combinado. No refeitório, a gente tem que comer tranquilo.

$P$ continua:

- Na hora do almoço, vou olhar quem vai se comportar. O Eduardo estava com os dois pés na mesa.

E: 
- O Jorge não comeu nada, hein.

$\mathrm{P:}$

- Hoje, a gente vai para o parque, depois nos vamos subir e fazer um baile na outra sala.

As professoras auxiliaram as crianças a tirarem as blusas, pois está um dia quente.

P:

- Agora vamos descer devagar.

\section{Brincar livre no parque}

\begin{tabular}{|l|l|}
\hline Data & $10 / 10 / 2013$ \\
\hline $\mathbf{N}^{\mathbf{o}}$ registro & 02 \\
\hline Horário & $09 \mathrm{~h} 45 \mathrm{~min}$ às $10 \mathrm{~h} 15 \mathrm{~min}$ \\
\hline Pesquisadora: Lídia Godoi \\
\hline Professoras envolvidas: E e P. \\
\hline Turma: MGI-AB \\
\hline $\begin{array}{l}\text { Crianças presentes: Matheus N., Marcos, Sarah, Zé, Mathias, Vinícius, Duda, Ingrid, } \\
\text { Lara, Eduardo, Amanda, Jorge, Thiago, Yasmin, Luiz, Jeferson, Vitor, Dhara, Giovana } \\
\text { (total de } 19 \text { crianças). }\end{array}$ \\
\hline
\end{tabular}

\begin{tabular}{|l|l|}
\hline Natureza da atividade e materiais & Brincar livre no parque. \\
\hline $\begin{array}{l}\text { Participação das crianças e produções } \\
\text { coletivas e individuais }\end{array}$ & Todas as crianças participam. \\
\hline $\begin{array}{l}\text { Comunicação: Adulto-criança / } \\
\text { criança-criança }\end{array}$ & $\begin{array}{l}\text { Adulto-criança: a professora brinca com as } \\
\text { crianças, conversa com elas sobre suas } \\
\text { experiências. } \\
\text { Criança-criança: as crianças conversam bastante } \\
\text { entre si nesse momento, brincam juntas em } \\
\text { pequenos grupos. }\end{array}$ \\
\hline $\begin{array}{l}\text { Acontecimentos planejados e } \\
\text { imprevistos }\end{array}$ & Não houve um planejamento prévio. \\
\hline
\end{tabular}

\section{Relatório}

P está na casinha do Tarzan com as crianças, brincando junto e conversando com o grupo de crianças que está próximo a ela.

Marcos, Vitor e Henrique fazem de conta que são cachorrinhos.

P:

- Nossa, quanto cachorrinho aqui. E pega Marcos no colo.

$\mathrm{P}$ :

- Tem que fazer roda de conversa sobre animais de estimação. No início do ano, a gente fazia bastante, mas eles falavam pouco. Agora eles falam muito.

- E você tem cachorro, Vitor? Pergunta P.

Vitor: 
- Não.

Ingrid:

- Eu tenho o Bob e o Mustafá.

P:

- Yasmin, tem cachorro? E gato?

Yasmin balança a cabeça para indicar que não.

Luiz:

- Eu tenho um peixe na minha casa.

P:

- É mesmo? E tem nome seu peixe?

Luiz:

- É Jú. Ele fica no meu aquário.

Do outro lado, embaixo da casinha do Tarzan, Yasmin e Henrique brincam de cachorro.

Do outro lado do parque, a diretora do CEI, E, fotografava as crianças brincando.

\section{Organização para o repouso}

\begin{tabular}{|l|l|}
\hline Data & $10 / 10 / 2013$ \\
\hline $\mathbf{N}^{\circ}$ registro & 03 \\
\hline Horário & $11 \mathrm{~h} 30 \mathrm{~min}$ às $11 \mathrm{~h} 40 \mathrm{~min}$ \\
\hline Pesquisadora: Lídia Godoi \\
\hline Professoras envolvidas: E e P. \\
\hline Turma: MGI-AB \\
\hline $\begin{array}{l}\text { Crianças presentes: Matheus N., Marcos, Sarah, Zé, Mathias, Vinícius, Duda, Ingrid, } \\
\text { Lara, Eduardo, Amanda, Jorge, Thiago, Yasmin, Luiz, Jeferson, Vitor, Dhara, Giovana } \\
\text { (total de } 19 \text { crianças). }\end{array}$ \\
\hline
\end{tabular}

\begin{tabular}{|l|l|}
\hline Natureza da atividade e materiais & Organização das crianças para o repouso. \\
\hline $\begin{array}{l}\text { Participação das crianças e produções } \\
\text { coletivas e individuais }\end{array}$ & Todas as crianças participam. \\
\hline $\begin{array}{l}\text { Comunicação: Adulto-criança / } \\
\text { criança-criança }\end{array}$ & $\begin{array}{l}\text { Adulto-criança: as professoras orientam as } \\
\text { crianças na organização. } \\
\text { Criança-criança: as crianças conversam pouco } \\
\text { entre si, mas auxiliam umas as outras. }\end{array}$ \\
\hline $\begin{array}{l}\text { Acontecimentos planejados e } \\
\text { imprevistos }\end{array}$ & Não houve planejamento prévio. \\
\hline
\end{tabular}

\section{Relatório}


E e P se dividem. Enquanto P auxilia as crianças no banheiro, E auxilia-as na sala. E:

- Gente, tira o cobertor do saquinho e guarda o saquinho embaixo do colchão.

As crianças, como no período da tarde, tiram sozinhas os tênis, guardam, tiram os cobertores e se cobrem. Enfim, organizam-se com o auxílio das professoras para dormir.

\section{Organização da sala após o sono}

\begin{tabular}{|l|l|}
\hline Data & $10 / 10 / 2013$ \\
\hline $\mathbf{N}^{\circ}$ registro & 04 \\
\hline Horário & $14 \mathrm{~h} 35 \mathrm{~min}$ às $15 \mathrm{~h} 00 \mathrm{~min}$ \\
\hline Pesquisadora: Lídia Godoi \\
\hline Professoras envolvidas: O e I \\
\hline Turma: MGI-AB \\
\hline $\begin{array}{l}\text { Crianças presentes: Matheus N., Marcos, Sarah, Zé, Mathias, Vinícius, Duda, Ingrid, } \\
\text { Lara, Eduardo, Amanda, Jorge, Thiago, Yasmin, Luiz, Jeferson, Vitor, Dhara, Giovana } \\
\text { (total de } 19 \text { crianças). }\end{array}$ \\
\hline
\end{tabular}

\begin{tabular}{|l|l|}
\hline Natureza da atividade e materiais & Organização da sala após o sono. \\
\hline $\begin{array}{l}\text { Participação das crianças e produções } \\
\text { coletivas e individuais }\end{array}$ & Todas as crianças participam. \\
\hline $\begin{array}{l}\text { Comunicação: Adulto-criança / } \\
\text { criança-criança }\end{array}$ & $\begin{array}{l}\text { Adulto-criança: as professoras orientam as } \\
\text { crianças na organização. } \\
\text { Criança-criança: as crianças conversampouco } \\
\text { entre si, mas auxiliam umas as outras. }\end{array}$ \\
\hline $\begin{array}{l}\text { Acontecimentos planejados e } \\
\text { imprevistos }\end{array}$ & Não houve um planejamento prévio. \\
\hline
\end{tabular}

\section{Relatório}

Por conta da organização referente à semana da criança, está a professora I na sala com a turma, enquanto $\mathrm{O}$ está organizando o espaço com áreas de interesse, onde irão brincar todas as turmas. Esse espaço será organizado na área azul. Uma quadra bem grande na área externa do CEI, com jogos e circuito pintados sobre o concreto, que é colorido de azul. Por isso, todos chamam essa área de área azul.

No momento de organização após o sono, as crianças tiram os lençóis, guardam e colocam seus sapatos. I só auxilia. Como as crianças ajudam, o processo fica mais fácil. Em seguida, I encaminha as crianças ao banheiro para fazer a higiene.

I:

- Pessoal, vamos lavar as mãos.

Entram primeiro as meninas, que fazem sua higiene sem problemas, depois os meninos. 
Enquanto uma turma lavava as mãos, I cantava com as outras que estavam esperando. I:

- A Duda caiu na piscina, caiu na piscina e não sabe nadar.

Duda grita:

- Socorro!

I:

- Quem é que vai te salvar?

Duda:

- A Sarah.

Canta-se novamente a música e assim uma criança vai escolhendo a outra para cair na piscina.

I:

- Nós vamos e quem quiser tomar leite vai ficar na fila. Quem não quiser pode ir sentar, Vamos.

As crianças descem para tomar o leite.

\section{Brincar livre na área azul}

\begin{tabular}{|l|l|}
\hline Data & $10 / 10 / 2013$ \\
\hline $\mathbf{N}^{\circ}$ registro & 05 \\
\hline Horário & $15 \mathrm{~h} 10 \mathrm{~min}$ às $16 \mathrm{~h} 15 \mathrm{~min}$ \\
\hline Pesquisadora: Lídia Godoi \\
\hline Professoras envolvidas: O e I \\
\hline Turma: MGI-AB \\
\hline $\begin{array}{l}\text { Crianças presentes: Matheus N., Marcos, Sarah, Zé, Mathias, Vinícius, Duda, Ingrid, } \\
\text { Lara, Eduardo, Amanda, Jorge, Thiago, Yasmin, Luiz, Jeferson, Vitor, Dhara, Giovana } \\
\text { (total de } 19 \text { crianças). }\end{array}$ \\
\hline
\end{tabular}

\begin{tabular}{|l|l|}
\hline Natureza da atividade e materiais & Brincar livre em áreas de interesse no pátio azul. \\
\hline $\begin{array}{l}\text { Participação das crianças e produções } \\
\text { coletivas e individuais }\end{array}$ & Todas as crianças participam. \\
\hline $\begin{array}{l}\text { Comunicação: Adulto-criança / } \\
\text { criança-criança }\end{array}$ & $\begin{array}{l}\text { Adulto-criança: as crianças brincam livremente } \\
\text { sem intervenções dos adultos. } \\
\text { Criança-criança: representam papéis no faz de } \\
\text { conta, organizam suas brincadeiras, conversam } \\
\text { entre si a todo momento, brincam juntas. }\end{array}$ \\
\hline $\begin{array}{l}\text { Acontecimentos planejados e } \\
\text { imprevistos }\end{array}$ & Todo ocorreu como planejado. \\
\hline
\end{tabular}

\section{Relatório}


Hoje, por conta da semana da criança, as professoras organizaram na quadra várias áreas de interesse. Esse espaço foi organizado para que todas as crianças presentes hoje na instituição pudessem brincar juntas.

Foram montadas as seguintes áreas: casinha, leitura, musica artes, escritório, bonecos, carros e miniaturas.

Abriu-se também o acesso da quadra ao parque, ampliando a movimentação das crianças e também as possibilidades de escolha.

I e $\mathrm{O}$ circulam entre as áreas. I organiza a área de música o uso do microfone, pois as crianças querem cantar.

Como o espaço é muito amplo e está ocupado por todas as turmas, não é possível acompanhar a turma toda. Observo um grupo de crianças na área dos bonecos.

Estão brincando juntos Viviane, Jeferson, Matheus, Marcos, Henrique e Mathias. Cada um deles com um boneco na mão. Como eles estão nesse movimento já faz algum tempo,

resolvo acompanhar.

Jeferson fala para Matheus:

- Peguem eles!

Mathias:

- 1, 2, 3, 8, 9 dá um golpe.

Henrique:

- Sou eu que vou bater em você.

Marcos:

- Eu sou o Max Still. Pega dois bonecos e começa bater um no outro.

Jeferson pega seu boneco e fala para Mathias:

- Ei amigo, quer beijar na minha boca?

Matheus aproxima seu boneco ao do Jeferson simulando um beijo.

Jeferson para Matheus:

- Olha, amigo, eu vou te salvar.

Matheus:

- Não vamos fugir. Você ouvirá esse barulho.

Há um tecido sobre a área dos bonecos. Jeferson e Matheus fazem de conta que o tecido é uma piscina.

Jeferson e Matheus saem correndo, Sarah e Marcos se aproximam de mim com um teclado de computador e duas caixinhas de som.

Sarah:

- Olha, a gente tá brincando de Xuxa.

Eles apertam os botões do teclado e depois mexem nas caixinhas.

Sarah:

- Aperta o da água.

Marcos coloca a mão na tecla.

Matheus se aproxima, Sara e Marcos vão para outro lugar.

Continuo na área dos bonecos, percebo Henrique com dois bonecos simulando uma luta.

Henrique:

- Eu vou te cortar. Ahhh!!!

Henrique passa um bom tempo fazendo movimentos de luta com os bonecos.

O clima é de alegria. A turma circula pelas áreas.

A ora circula pelas áreas, ora para e auxilia as crianças que solicitam.

I permaneceu até agora na área de música com as crianças.

A turma está toda distribuída entre as áreas.

A está a maior parte do tempo circulando pelas áreas, organizando os objetos. Em alguns momentos, senta-se e observa no que as crianças estão envolvidas. 
Vou até a área da casinha. Ingrid e Dhara estão envolvidas num jogo simbólico em que Dhara é a mãe e Ingrid é a filha.

Chego no momento em que Ingrid coloca sua filha para dormir. Ela mostra alguns livros e diz:

- Qual história você quer?

As duas histórias eram sobre animais, uma de urso e outra de baleia.

Dhara escolhe a da baleia.

Vivi começa:

- Uma vez tinha um baco que é de pirata, assustador. Tinha muito peixe no mar.

Vivi se aproxima. Abre um sorriso para pegar o livro da baleia. Ingrid dá na mão da Vivi.

Vivi folheia o livro.

Ingrid fala para Dhara:

- Vau filha, dorme.

Quando Dhara se me mexe e se descobre, Ingrid volta a cobri-la.

Ingrid e Vivi vão até a cozinha.

Ingrid:

- Viviane tem comida. Faz comida.

Ingrid não larga o livro da baleia.

Eduardo se aproxima.

Ingrid:

- Vai! Domi!

Ingrid pega uma boneca, segura no colo como se fosse uma criança vai até o fogão.

- Vô faze comida!

- Ingrid:

- Dhara. Vamo comer. Abre a boca.

Ingrid dá "comida" na boca de Dhara.

Agora a filhinha é Sarah.

Ingrid:

- Vem, tó comida.

Hora de guardar. Com a ajuda das crianças, as professoras guardam os materiais.

\section{Impressões gerais}

\section{0/10/2013 - IMPRESSÕES GERAIS - MANHÃ}

Hoje, a organização da rotina foi a mesma, contudo pensada de forma mais dinâmica. As crianças puderam se servir no café, a entrada do CEI estava bonita, aconchegante, convidativa. Tal organização se deve à semana da criança. Durante essa semana, foram propostas refeições diferentes, preparadas de forma também diferente da habitual. As crianças tiveram atividades durante toda a manhã. As crianças tomaram suco embaixo de uma árvore no parque, sentadas sobre um tecido colorido. Fico pensando, o que faz com que essas coisas aconteçam dessa forma na semana das crianças?

\section{0/10/2013 - IMPRESSÕES GERAIS - TARDE}

À tarde, seguiu-se a mesma dinâmica do período da manhã. Todas as professoras se organizaram para pensar um espaço amplo em que as crianças pudessem brincar livremente. As professoras R e A estiveram sempre circulando pelo espaço, fotografando as crianças da turma e organizando as áreas quando consideravam necessário. 
$22 / 10 / 2013$

Atividade dirigida - construção do quebra-cabeça

\begin{tabular}{|l|l|}
\hline Data & $22 / 10 / 2013$ \\
\hline $\mathbf{N}^{\mathbf{0}}$ registro & 01 \\
\hline Horário & $09 \mathrm{~h} 15 \mathrm{~min}$ às 09h50min \\
\hline Pesquisadora: Lídia Godoi \\
\hline Professoras envolvidas: P e V \\
\hline Turma: MGI-AB \\
\hline $\begin{array}{l}\text { Crianças presentes: Mathias, Thiago, Vinícius, Mateus, Viviany, Yasmin, Eduardo, } \\
\text { Matheus, Vitor, José Ricardo, Maria Eduarda, Dhara, Giovana, Marcos, Ingrid, Henrique, } \\
\text { Sophia, Sarah, Jeferson, Luiz Gustavo, Laura, Jorge, Amanda (total de 22 crianças). }\end{array}$ \\
\hline
\end{tabular}

\begin{tabular}{|l|l|}
\hline Natureza da atividade e materiais & Atividade dirigida: construção do quebra-cabeça. \\
\hline $\begin{array}{l}\text { Participação das crianças e produções } \\
\text { coletivas e individuais }\end{array}$ & $\begin{array}{l}\text { Todas as crianças participam. Enquanto um } \\
\text { grupo brinca com os jogos de encaixe, o outro } \\
\text { constrói o quebra-cabeça. }\end{array}$ \\
\hline $\begin{array}{l}\text { Comunicação: Adulto-criança / } \\
\text { criança-criança }\end{array}$ & $\begin{array}{l}\text { Adulto-criança: as professoras explicam o } \\
\text { procedimento para as crianças e as auxiliam } \\
\text { quando necessário. } \\
\text { Criança-criança: as crianças conversam pouco } \\
\text { entre si durante a atividade. }\end{array}$ \\
\hline $\begin{array}{l}\text { Acontecimentos planejados e } \\
\text { imprevistos }\end{array}$ & $\begin{array}{l}\text { Houve pesagem das crianças nesse dia sem o } \\
\text { aviso prévio, o que dificultou a realização da } \\
\text { atividade como fora planejada. }\end{array}$ \\
\hline
\end{tabular}

\section{Relatório}

Em roda, P retoma a atividade. Vocês lembram daquele dia que a gente juntou os animais?

$P$ vai mostrando as imagens.

- Quem era esse, turminha?

Coro:

- A foca.

$\mathrm{P}$ foi mostrando os animais e imagens.

P:

- A gente vai pintar as peças com a esponja, depois juntar as peças e colar. 
As professoras haviam planejado fazer essa atividade no lactário, onde tem as mesas e bancos, um local que se usa geralmente para essas atividades, entretanto já existe uma outra turma pintando lá nesse momento, o que fez com que os planos mudassem de forma que elas tiveram que pensar em outro lugar para pintar.

$\mathrm{P}$ e V organizam o ambiente para pintura.

Dispersaram alguns brinquedos em uma área da sala, e em outra colocaram os materiais para pintura.

$\mathrm{V}$ :

- Ó, escuta como vamos organizar. A professora $\mathrm{P}$ vai chamar 8 crianças que vão pintar.

A outra turma vai ficar no brinquedo.

P:

- Cada dupla vai ser pintada da mesma cor.

Cada criança recebeu uma imagem e um prato de tinta. A mesa em que a imagem era um sapo recebeu tinta verde, a mesa em que a imagem era o pato recebeu tinta amarela.

Matheus sai da mesa em que havia tinta verde, passa esponja na tinta, em seguida, passa no desenho.

P:

- Nossa, Mateus! Olha o que você fez.

$\mathrm{V}$ :

- Vivi, você já terminou, agora vai lavar as mãos, tá!

Ao perceber que a imagem foi coberta de tinta, as professoras solicitam que as crianças lavem suas mãos.

V chama outra turma de 8 crianças que se sentam à mesa da pintura e aguardam os materiais.

P:

- Agora é a foca. A foca vai ser mais acinzentada.

V explica:

- Pessoal, é assim ó! Coloca a esponja na tinta e cobre o desenho. Vai fazendo assim. (V faz os movimentos para demonstras as crianças).

$\mathrm{Na}$ mesa um, que a professora deu o polvo, as crianças pintaram. Somente a tinta azul foi preparada pela $P$.

$\mathrm{V}$ traz as esponjas, como só havia aquelas, era preciso lavar a cada uso. V lavava as esponjas e entregava nas mãos das crianças.

Ao perceber que Marcos já havia coberto todo o desenho, V diz:

- Já terminou, Marcos, agora vai lavar as mãos. Olha, P! Ele fez em um minuto.

$\mathrm{V}$ :

- Turminha, agora senta lá no tapete que eu vou chamar mais crianças.

Algumas crianças querem pintar novamente, $\mathrm{V}$ explica que eles já foram.

Observo Sarah, Henrique, Lara e Jeferson na mesa de pintura na mesa de pintura esperando.

Sarah tenta colocar o dedo na tinta.

Luiz:

- Não mexe. Não pode mexer.

Lara:

- Não deixa aí. Não mexe.

NA mesa em que as crianças iam pintar o coelho havia tinta laranja, na mesa em que deviam pintaR o leão havia tinta vermelha.

$\mathrm{V}$ :

- Sarinha, já está bom. Vem com a V lavar a mãozinha.

Sarah não quer sair.

$\mathrm{P}$ se aproxima. 
- Nossa, a Sarah pintou tudo. Tá ótimo, depois a gente vai recortar.

Sarah se dirige ao banheiro para lavar as mãos.

Terminada a pintura.

P:

- Turminha, agora sentem no tapete para brincar que nós vamos organizar a sala.

Passado alguns minutos.

P:

- Turminha, agora a gente vai guardar para conversar sobre a pintura.

As crianças ajudam a guardar.

P:

- Agora todo mundo sentado pra gente conversar. Hoje, vocês estão mais agitados porque a gente fez pintura. Amanhã, iremos recortar e colar o quebra-cabeça. Agora, agente vai descer pra tomar suco. Depois do suco, tem o parque. Vamos descer devagarzinho.

\section{Brincar livre no parque}

\begin{tabular}{|l|l|}
\hline Data & $22 / 10 / 2013$ \\
\hline $\mathbf{N}^{\mathbf{0}}$ registro & 02 \\
\hline Horário & 09h50min às 11h00min \\
\hline Pesquisadora: Lídia Godoi \\
\hline Professoras envolvidas: P e V \\
\hline Turma: MGI-AB \\
\hline $\begin{array}{l}\text { Crianças presentes: Mathias, Thiago, Vinícius, Mateus, Viviany, Yasmin, Eduardo, } \\
\text { Matheus, Vitor, José Ricardo, Maria Eduarda, Dhara, Giovana, Marcos, Ingrid, Henrique, } \\
\text { Sophia, Sarah, Jeferson, Luiz Gustavo, Laura, Jorge, Amanda (total de 22 crianças). }\end{array}$ \\
\hline
\end{tabular}

\begin{tabular}{|l|l|}
\hline Natureza da atividade e materiais & Brincar livre no parque - Atividade permanente. \\
\hline $\begin{array}{l}\text { Participação das crianças e produções } \\
\text { coletivas e individuais }\end{array}$ & $\begin{array}{l}\text { Todas as crianças participam. Brincam, } \\
\text { conversam, criam brincadeiras. }\end{array}$ \\
\hline $\begin{array}{l}\text { Comunicação: Adulto-criança / } \\
\text { criança-criança }\end{array}$ & $\begin{array}{l}\text { Adulto-criança: comunicação gestual e oral. } \\
\text { Criança-criança: comunicação gestual e oral, as } \\
\text { crianças conversam entre si o tempo todo. }\end{array}$ \\
\hline $\begin{array}{l}\text { Acontecimentos planejados e } \\
\text { imprevistos }\end{array}$ & \\
\hline
\end{tabular}

\section{Relatório}

Após o suco, a turma sai para brincar no parque, onde já estão brincando as crianças do MG-I. Estão disponíveis triciclos, baldes, pás e moldes para brincar na areia, e também regadores e torneiras ao alcance das crianças. 
Mathias e Zé brincam juntos na balança. O Mathias empurra a balança para o Zé.

Jeferson, Henrique, Sophia e Jorge correm pelo parque. Vão até a casa do Tarzan, ficam láembaixojuntos.

Eu me aproximo de um deles, o Jorge.

Ele diz:

- Cuidado, foge do lobo!

Depois de correr bastante, fugindo de um lobo imaginário, Sophia e Henrique decidem brincar na areia, ora fazendo, marcas ora pulando.

Luiz, Jorge, Marcos, Mathias e Vitor também brincam juntos. Correm na maior velocidade no triciclo, um atrás do outro, sempre fazendo o mesmo percurso que vai de um lado a outro da área revestida de concreto do parque.

Vou para uma das pontas do percurso para ver o que eles falavam, pois sempre naquela parte eles paravam e conversavam algo.

Matheus é o primeiro a chegar, logo depois chegam Mathias, Vitor, Jorge, Luiz e Marcos.

Matheus grita:

- Olha o lobo!

Todos saem correndo com o triciclo.

Luiz volta para perto de mim. Apontando para o Matheus, ele diz para Vitor:

- Olha ali o bicho.

Percebo que as crianças estão brincando de uma espécie de pega-pega em que eles têm de fugir do Matheus, todos com triciclo.

Vitor:

- Matheus, você não vem atrás de mim! Matheus, de triciclo, tenta alcançar Vitor, também no triciclo. Nesse momento, as crianças utilizam o triciclo para experimentar diversos movimentos e sensações. Podendo ainda reinventar brincadeiras, criando o que chamei de "pega-pega com triciclos".

De repente, a moto vira. Matheus simula um acidente.

As crianças simulam situações do cotidiano em suas brincadeiras.

Jorge:

- Olha, é cavalo de pau. Dá uma parada brusca com o triciclo que produz um som forte e joga o triciclo todo para um lado só. Nesse momento, eles não experimentam só a sensação que essa ação causa, mas também o som que se produz com o atrito do pneu do triciclo no concreto.

Repetem esse movimento inúmeras vezes.

Marcos e Matheus trocam de triciclo, pegam outro modelo. Um mais alto e com pedal.

Marcos experimenta "fazer cavalo de pau" com outro triciclo. Os dois exploram outro objeto e tentam descobrir outras possibilidades com seu uso. Procuram maneiras de experimentar outras sensações.

O grupo de crianças permanece nessa brincadeira durante todo o período no parque.

Roda de conversa

\begin{tabular}{|l|l|}
\hline Data & $22 / 10 / 2013$ \\
\hline $\mathbf{N}^{\mathbf{o}}$ registro & 03 \\
\hline Horário & $14 \mathrm{~h} 50 \mathrm{~min}$ às $15 \mathrm{~h} 50 \mathrm{~min}$ \\
\hline Pesquisadora: Lídia Godoi \\
\hline Professoras envolvidas: O \\
\hline
\end{tabular}




\section{Turma: MGI-AB}

Crianças presentes: Mathias, Thiago, Vinícius, Mateus, Viviany, Yasmin, Eduardo, Matheus, Vitor, José Ricardo, Maria Eduarda, Dhara, Giovana, Marcos, Ingrid, Henrique, Sophia, Sarah, Jeferson, Luiz Gustavo, Laura, Jorge, Amanda (total de 22 crianças).

\begin{tabular}{|l|l|}
\hline Natureza da atividade e materiais & Roda de conversa. \\
\hline $\begin{array}{l}\text { Participação das crianças e produções } \\
\text { coletivas e individuais }\end{array}$ & $\begin{array}{l}\text { As crianças ficam livres para participar da } \\
\text { conversa. }\end{array}$ \\
\hline $\begin{array}{l}\text { Comunicação: Adulto-criança / } \\
\text { criança-criança }\end{array}$ & $\begin{array}{l}\text { Adulto-criança: comunicação gestual e oral. A } \\
\text { conversa é conduzida pela professora. } \\
\text { Criança-criança: comunicação gestual, } \\
\text { predomina a comunicação entre as crianças e a } \\
\text { professora. }\end{array}$ \\
\hline $\begin{array}{l}\text { Acontecimentos planejados e } \\
\text { imprevistos }\end{array}$ & $\begin{array}{l}\text { Imprevisto: a ausência de uma da professora da } \\
\text { turma provocou a redistribuição das crianças em } \\
\text { outras salas. }\end{array}$ \\
\hline
\end{tabular}

\section{Relatório}

Hoje, a professora O ficará sozinha com 12 crianças. A outra parte da turma será redistribuída pelas salas de mini grupo 2 .

Nesta tarde, vou acompanhar uma atividade livre e outra dirigida. Os momentos de higiene e alimentação não serão acompanhados.

O explica que hoje ela iria fazer a pesquisa sonora. Desenho do som. E depois eles iriam ao parque, mas como há previsão de chuva, ela preferiu ir ao parque no primeiro horário, antes da chuva e só depois fazer a pesquisa sonora.

\section{Roda:}

$\mathrm{O}$ :

Hoje a I não vai, ela tá com dor no braço e foi pro médico. Como a I não veio, a $\mathrm{O}$ não vai poder ficar com a turma toda. Então, algumas crianças vão ficar na sala de baixo. Eu vou dizer quem vai ficar: Luiz, Mathias, Jeferson, Jorge, Vinícius, Vivian, Matheus, Thiago, Marcos, Sara e Lara.

Duda:

- O, quero ir também.

$\mathrm{O}$ :

- Outro dia você vai, Duda.

As crianças que foram redistribuídas são as crianças da turma da professora I. Aquelas que fazem parte da lista da professora $\mathrm{O}$ ficaram com ela.

As crianças pegam as mochilas no armário, colocam nas costas e são conduzidas por um Agente de Apoio até a sala. 
Brincar livre no solário

\begin{tabular}{|l|l|}
\hline Data & $22 / 10 / 2013$ \\
\hline $\mathbf{N}^{\mathbf{o}}$ registro & 04 \\
\hline Horário & $15 \mathrm{~h} 15 \mathrm{~min}$ às $15 \mathrm{~h} 45 \mathrm{~min}$ \\
\hline Pesquisadora: Lídia Godoi \\
\hline Professoras envolvidas: O \\
\hline Turma: MGI-AB \\
\hline $\begin{array}{l}\text { Crianças presentes: Mathias, Thiago, Vinícius, Mateus, Viviany, Yasmin, Eduardo, } \\
\text { Matheus, Vitor, José Ricardo, Maria Eduarda, Dhara, Giovana, Marcos, Ingrid, Henrique, } \\
\text { Sophia, Sarah, Jeferson, Luiz Gustavo, Laura, Jorge, Amanda (total de 22 crianças). }\end{array}$ \\
\hline
\end{tabular}

\begin{tabular}{|l|l|}
\hline Natureza da atividade e materiais & Brincar livre no solário. \\
\hline $\begin{array}{l}\text { Participação das crianças e produções } \\
\text { coletivas e individuais }\end{array}$ & $\begin{array}{l}\text { As crianças ficam livres para brincar sem } \\
\text { maiores intervenções dos adultos. Criam } \\
\text { brincadeiras e brincam em grupos. }\end{array}$ \\
\hline $\begin{array}{l}\text { Comunicação: Adulto-criança / } \\
\text { criança-criança }\end{array}$ & $\begin{array}{l}\text { Adulto-criança: comunicação gestual e oral. A } \\
\text { professora participa sempre que as crianças } \\
\text { solicitam. } \\
\text { Criança-criança: comunicação gestual e oral. As } \\
\text { crianças conversam bastante entre si. }\end{array}$ \\
\hline $\begin{array}{l}\text { Acontecimentos planejados e } \\
\text { imprevistos }\end{array}$ & \\
\hline
\end{tabular}

\section{Relatório}

Como todas as turmas estavam no parque, O considerou que o melhor seria brincar no solário.

No solário, havia motocas, escorregadores e gangorras.

Vitor e Matheus, que brincavam fazendo circuito de triciclos pela manhã, escolhem carrinhos e continuam o movimento iniciado durante a manhã.

Vitor se aproxima como o carro e diz:

- A gente tá indo pra escolinha.

Eles pedalam com toda força para atingir o máximo de velocidade com o carrinho. Vitor se envolve em uma brincadeira de pega-pega com Matheus, Henrique e Zé. Vitor imita um monstro com garras, e Matheus, Henrique e Zé correm para fugir do monstro. Eles brincam sem interferência da professora, que, nesse momento, só observa.

Dhara, Giovana, Henrique e Zé brincam juntos na gangorra.

Vitor se aproxima.

- Argh!! (imitando um monstro)

Zé:

- Sai! Eu sou o Ben 10.

Henrique:

- Eu sou o homem aranha. 
Edu, Giovana, Matheus e Vitor se envolvem em uma brincadeira que criaram, utilizando o escorregador.

Criaram uma experiência desafiadora que exigia habilidades motoras. Eles subiam até o topo do escorregador e saltavam do mais distante que podiam.

Permaneceram um bom tempo nesse movimento.

Hora de ir para a sala (foto).

O:

- Pessoal, vamos organizar os brinquedos? Porque depois vamos para a sala.

Atividade dirigida - pesquisa sonora

\begin{tabular}{|l|l|}
\hline Data & $22 / 10 / 2013$ \\
\hline $\mathbf{N}^{\circ}$ registro & 05 \\
\hline Horário & $15 \mathrm{~h} 15 \mathrm{~min}$ às $15 \mathrm{~h} 45 \mathrm{~min}$ \\
\hline Pesquisadora: Lídia Godoi \\
\hline Professoras envolvidas: O \\
\hline Turma: MGI-AB \\
\hline $\begin{array}{l}\text { Crianças presentes: Mathias, Thiago, Vinícius, Mateus, Viviany, Yasmin, Eduardo, } \\
\text { Matheus, Vitor, José Ricardo, Maria Eduarda, Dhara, Giovana, Marcos, Ingrid, Henrique, } \\
\text { Sophia, Sarah, Jeferson, Luiz Gustavo, Laura, Jorge, Amanda (total de 22 crianças). }\end{array}$ \\
\hline
\end{tabular}

\begin{tabular}{|l|l|}
\hline Natureza da atividade e materiais & Pesquisa sonora - Atividade dirigida. \\
\hline $\begin{array}{l}\text { Participação das crianças e produções } \\
\text { coletivas e individuais }\end{array}$ & Todas as crianças realizam a atividade. \\
\hline $\begin{array}{l}\text { Comunicação: Adulto-criança / } \\
\text { criança-criança }\end{array}$ & $\begin{array}{l}\text { Adulto-criança: comunicação gestual e oral. A } \\
\text { professora conversa com as crianças e as orienta } \\
\text { na realização da atividade. } \\
\text { Criança-criança: comunicação oral e gestual. } \\
\text { Contudo, as crianças conversam pouco entre si. }\end{array}$ \\
\hline $\begin{array}{l}\text { Acontecimentos planejados e } \\
\text { imprevistos }\end{array}$ & $\begin{array}{l}\text { Imprevisto: a ausência de uma das professoras } \\
\text { dificultou a organização da sala para a atividade. }\end{array}$ \\
\hline
\end{tabular}

\section{Relatório}

Quando chegamos, a sala já estava organizada. Fiquei um pouco com as crianças durante o solário para que a $\mathrm{O}$ pudesse organizar.

A turma entrou e sem que $O$ pedisse e sentaram-se em roda no tapete.

O:

- Olha esse CD que a I trouxe. É de músicas clássicas. Essas músicas são tocadas com piano. Vamos escutar um pouquinho pra ver como que é? 
Coro:

- Vamos!

$\mathrm{O}$ :

- Então eu vou colocar.

O mostra o CD, na capa tem um piano de cauda.

O inicia a música. Eduardo diz:

- Acho que é um príncipe (relacionando com músicas de filmes que certamente já ouviu)

$\mathrm{O}$ :

- Esse som tá fraco ou forte?

Ingrid, Dhara e Edu:

- Forte!

A outra música o som é baixo.

Edu fala:

- Tá bem fraquinho.

O coloca uma música mais rápida e pergunta:

- Essa música é rápida ou devagar?

Vitor:

- É rápido!

$\mathrm{O}$ :

- Piano é um instrumento que toca assim ó, com os dedos (O faz gestos e a turma começa a imitar).

A cada música as crianças falam se é forte ou fraco, lento ou rápido, tentando definir as propriedades do som.

Escutam atentamente as músicas.

$\mathrm{O}$ :

- Sabe o que a gente vai fazer agora? Tá vendo aquele papel que está na parede? Cada um vai pegar uma canetinha e desenhar no ritmo da música.

Hoje, a Ingrid é a ajudante do dia. Ingrid pega o pote de canetinhas e passa para cada um escolher a sua.

Cada criança escolheu uma canetinha. O coloca a música como fundo para que as crianças comecem a desenhar.

Matheus vai até a parte do cantinho para trocar a cor.

A:

- Não é para trocar, é para ficar com a mesma canetinha.

Ao perceber que a música está mais lenta, Vitor reduz o ritmo dos traços.

Ingrid desenha sempre na mesma velocidade, que não se alterou com o ritmo da música.

Amanda desenha uma figura formada por um círculo e algumas linhas horizontais.

O experimenta colocar músicas que fazem parte do repertório das crianças e que elas escutam com frequência em casa ou na rua. Funk, sertanejo...

Dhara, Amanda e Edu param de desenhar e ficam só dançando. Henrique continua desenhando, traçando linhas vagarosamente pelo papel.

Duda faz vários círculos no papel e prefere continuar desenhando.

O:

- Acho que a música não influenciou em nada.

O:

- Quem não quer mais desenhar, devolve a canetinha no pote.

A muda de ideia e propõe:

- Olha, a canetinha pode ser um microfone. Quem que cantar no microfone?

Algumas crianças aceitam a sugestão da professora e começam a cantar utilizando a canetinha como microfone. 
A turma dança e canta livremente.

\section{Impressões gerais}

\section{2/10/2013 - IMPRESSÕES GERAIS - MANHÃ}

Hoje, pela manhã, percebi o quanto estamos influenciadas por um currículo fragmentado, e o quanto pensamos também de forma fragmentada, o quanto ainda temos a necessidade de que tudo saia como queremos, de manter a ordem. Se no brincar livre, as crianças têm toda a liberdade, no momento das experiências consideradas "dirigidas", realmente dirige-se tudo, escolha de materiais, suportes, modo de fazer. Nesse momento, predomina um currículo totalmente prescritivo.

\section{2/10/2013 - IMPRESSÕES GERAIS - TARDE}

Pela manhã, as crianças abordam os animais; à tarde, a pesquisa sonora, contudo sem nenhuma ligação entre as temáticas. É como se à tarde fosse outro grupo de crianças, talvez isso aconteça porque o que se está levando em conta ao planejar não seja o interesse das crianças, e sim o ponto de vista adulto. Temos ainda uma forma adultocêntrica de pensar, considerando os referenciais da Sociologia da Infância. Isso faz com que as crianças vivam em mundos diferentes sem nenhuma conexão.

$05 / 11 / 2013$

Brincar livre no parque

\begin{tabular}{|l|l|}
\hline Data & $05 / 11 / 2013$ \\
\hline $\mathbf{N}^{\mathbf{0}}$ registro & 01 \\
\hline Horário & $09 \mathrm{~h} 10 \mathrm{~min}$ às 10h00min \\
\hline Pesquisadora: Lídia Godoi \\
\hline Professoras envolvidas: P e V. \\
\hline Turma: MGI-AB \\
\hline $\begin{array}{l}\text { Crianças presentes: Viviany, Dhara, Ingrid, Maria Eduarda, Mathias, Victor, Eduardo, } \\
\text { Yasmin, Sarah, José Ricardo, Matheus, Vinícius, Giovana, Thiago, Henrique, Sophia, } \\
\text { Marcos, Jeferson, Luiz Gustavo, Lara, Jorge (total de 21 crianças). }\end{array}$ \\
\hline
\end{tabular}

\begin{tabular}{|l|l|}
\hline Natureza da atividade e materiais & Atividade permanente envolvendo o brincar livre. \\
\hline Participação das crianças e & Todas as crianças participam. Inventam suas \\
\hline
\end{tabular}




\begin{tabular}{|l|l|}
\hline produções coletivas e individuais & brincadeiras juntas ou em pequenos grupos. \\
\hline $\begin{array}{l}\text { Comunicação: Adulto-criança / } \\
\text { criança-criança }\end{array}$ & $\begin{array}{l}\text { Adulto-criança: as professoras auxiliam as } \\
\text { crianças quando chamadas pelas mesmas. }\end{array}$ \\
\hline $\begin{array}{l}\text { Acontecimentos planejados e } \\
\text { imprevistos }\end{array}$ & \\
\hline
\end{tabular}

\section{Relatório}

No parque, a turma brinca na área revestida de cimento com os triciclos. As professoras abriram a área azul para que as crianças tenham mais espaço. Brincam juntas as duas turmas de MG1.

Como na área azul existe um percurso desenhado no chão, as crianças utilizam os triciclos para fazer esse percurso.

Paulo, Vitor, Marcos, Luiz, Thiago, Mathias, Dhara e Henrique estão correndo de um lado a outro da área azul.

Vitor:

- Corre, é o lobo!

Todos correm gritando. Estão fugindo do lobo, que é representado pelo Matheus Nogueira. A turma sempre forma essa brincadeira no parque.

As crianças percorrem todo o espaço do parque, fugindo do "lobo".

Agora a brincadeira é outra.

Luiz, Vitor e Marcos são os cachorrinhos. Sarah é a dona. Ela prepara comida para os cachorrinhos.

Sarah:

- Vem cachorro, comer ração. (Utiliza na brincadeira os conhecimentos que possui sobre cachorros.)

As crianças latem. Sarah faz carinho na Yasmin, como se ela fosse um cachorrinho.

Sarah:

- Olha, esses amiguinhos eram cachorros.

Marcos:

- Eu comi ração.

Como aponta Vygotsky, as crianças estão envolvidas em um jogo com regras, em que resumem diversas habilidades e conhecimentos sobre esse animal: latir, comer ração, a prática social de acarinhar e acalentar os animais.

Pergunto:

- Nossa! Que cachorros fofos!

Sarah:

- São de mentirinha.

Vitor e Luiz correm atrás do triciclo da Giovanna (como fazem os cachorrinhos).

Sarah:

- Vem cachorrinho. Vou levar pra passear na rua.

Sarah, Yasmin e Luiz saem para o passeio.

Pergunto para $\mathrm{P}$ se, no projeto que elas estão trabalhando, elas trabalham coisas sobre cachorros. Ela disse que passaram dois meses e fizeram rodas conversando sobre esses animais, mas não deram ênfase, não fizeram uma investigação sobre. 
Pesagem e roda de história

\begin{tabular}{|l|l|}
\hline Data & $05 / 11 / 2013$ \\
\hline $\mathbf{N}^{\mathbf{0}}$ registro & 02 \\
\hline Horário & $10 \mathrm{~h} 10 \mathrm{~min}$ às 10h55min \\
\hline Pesquisadora: Lídia Godoi \\
\hline Professoras envolvidas: Pe V \\
\hline Turma: MGI-AB \\
\hline $\begin{array}{l}\text { Crianças presentes: Viviany, Dhara, Ingrid, Maria Eduarda, Mathias, Victor, Eduardo, } \\
\text { Yasmin, Sarah, José Ricardo, Matheus, Vinícius, Giovana, Thiago, Henrique, Sophia, } \\
\text { Marcos, Jeferson, Luiz Gustavo, Lara, Jorge (total de 21 crianças). }\end{array}$ \\
\hline
\end{tabular}

\begin{tabular}{|l|l|}
\hline Natureza da atividade e materiais & $\begin{array}{l}\text { Roda de história (atividade permanente) / } \\
\text { pesagem das crianças (esporádico, } \\
\text { determinações de SME). }\end{array}$ \\
\hline $\begin{array}{l}\text { Participação das crianças e produções } \\
\text { coletivas e individuais }\end{array}$ & $\begin{array}{l}\text { Todas as crianças participam. Na pesagem, tiram } \\
\text { sua própria roupa e colocam perto das mochilas, } \\
\text { facilitando assim o trabalho das professoras. } \\
\text { Durante a roda de história, permanecem atentas, } \\
\text { escutando tudo. }\end{array}$ \\
\hline $\begin{array}{l}\text { Comunicação: Adulto-criança / } \\
\text { criança-criança }\end{array}$ & $\begin{array}{l}\text { Adulto-criança: as professoras auxiliam as } \\
\text { crianças com seus pertences. Cantam e contam } \\
\text { histórias na roda de história. }\end{array}$ \\
\hline $\begin{array}{l}\text { Acontecimentos planejados e } \\
\text { imprevistos }\end{array}$ & Não houve um planejamento prévio. \\
\hline
\end{tabular}

\section{Relatório}

Na sala, as professoras $\mathrm{P}$ e $\mathrm{V}$ me explicam que agora vão ter de tirar blusas e sapatos das crianças para pesar. $\mathrm{V}$ me explica que elas não sabiam disso.

As professoras terão de se organizar para a passagem das crianças de última hora. $O$ fato de ficarem sabendo na hora, dificultou a organização, embora as crianças colaborem bastante, tirando suas roupas e organizando as mochilas.

Enquanto V está auxiliando na pesagem, $\mathrm{P}$ ajuda as crianças na organização na sala.

P:

- Quem já colocou a roupa e tênis senta no tapete, vou contar uma história.

Marcos, Duda e Lara em coro dizem:

- Obaa!!

P:

- Essa história é bem legal, é de um animal. Ele tem uma boca grande.

Marcos:

- É um jacaré. 
P:

- Não acredito! Marcos acertou de primeira. É do jacaré!

P canta:

- "Jacaré, passeando na lagoa".

As crianças acompanham.

P:

- O título desse livro é: "E o dente ainda doía". Quem escreveu foi Ana Terra. Ela que escreveu o livro.

As crianças escutam atentamente enquanto $\mathrm{P}$ conta a história.

O livro conta a história de um jacaré que está com dor de dente. Vários animais, coelhos, ratos, toupeiras, tentam ajudá-lo para que a dor passe.

Durante a história, $\mathrm{P}$ convida as crianças para contar os animais.

P:

- Vamos contar quantas toupeirinhas saíram do buraco?

$\mathrm{V}$ :

- Será que eles conseguem, P?

$\mathrm{P}$ :

- Claro! Pra quem já consegue contar até 20.

Aos poucos, as crianças vão adiantando as falas.

Vivi:

- E o dente ainda doía...

$\mathrm{P}$ :

- O jacaré já fez tanta coisa e ainda está com dor de dente. O que ele pode fazer para sarar? Jorge:

- Bebe água.

Marcos:

- Tomar remédio.

Mathias:

- Bebe leite.

Eduardo:

- Leite com Nescau.

$\mathrm{P}$ :

- Quando o dente de vocês doem, o que que a mamãe faz?

Ingrid:

- Minha mãe fica com dor de cabeça lá em casa.

P:

- Vamos descobrir o que o jacaré fez?

$\mathrm{V}$ :

- Vamos cantar a música do sítio do Seu Lobato?

- "A Viviane tinha um sítio ia, ia, ô... E nesse sítio tinha um jacaré, ia, ia, ô..."

$\mathrm{V}$ :

- Agora chegou a hora do almoço.

Começam a cantar:

- "Meu almoço, meu almoço, vou comer, vou comer, pra ficar fortinho, pra ficar fortinho, e crescer, e crescer..."

\section{Almoço}

\section{Data} $05 / 11 / 2013$ 


\begin{tabular}{|l|l|}
\hline $\mathbf{N}^{\mathbf{0}}$ registro & 03 \\
\hline Horário & $10 \mathrm{~h} 55 \mathrm{~min}$ às $11 \mathrm{~h} 25 \mathrm{~min}$ \\
\hline Pesquisadora: Lídia Godoi \\
\hline Professoras envolvidas: P e V \\
\hline Turma: MGI-AB \\
\hline $\begin{array}{l}\text { Crianças presentes: Viviany, Dhara, Ingrid, Maria Eduarda, Mathias, Victor, Eduardo, } \\
\text { Yasmin, Sarah, José Ricardo, Matheus, Vinícius, Giovana, Thiago, Henrique, Sophia, } \\
\text { Marcos, Jeferson, Luiz Gustavo, Lara, Jorge (total de 21 crianças). }\end{array}$ \\
\hline
\end{tabular}

\begin{tabular}{|l|l|}
\hline Natureza da atividade e materiais & Alimentação. \\
\hline $\begin{array}{l}\text { Participação das crianças e } \\
\text { produções coletivas e individuais }\end{array}$ & $\begin{array}{l}\text { Todas as crianças participam. Comem sozinhas, } \\
\text { contudo, não se servem. }\end{array}$ \\
\hline $\begin{array}{l}\text { Comunicação: Adulto-criança / } \\
\text { criança-criança }\end{array}$ & $\begin{array}{l}\text { Adulto-criança: as professoras auxiliam as } \\
\text { crianças quando solicitadas, incentivando-as a se } \\
\text { alimentar. }\end{array}$ \\
\hline $\begin{array}{l}\text { Acontecimentos planejados e } \\
\text { imprevistos }\end{array}$ & \\
\hline
\end{tabular}

\section{Relatório}

$\mathrm{P}$ distribui os pratos para as crianças, já estão todas sentadas à mesa.

P:

- Tá quente. Espera esfriar um pouquinho!

As crianças conversam entre si enquanto comem.

$\mathrm{V}$ auxilia as crianças que têm maior dificuldade para comer.

As crianças que não querem mais comer esvaziam seus pratos.

Hora da sobremesa. P e V distribuem, hoje é gelatina.

Vivi anda não terminou com a comida.

Sarah e Vitor brincam com as colheres enquanto comem a gelatina sem intervenção dos professores.

Matheus, Sarah e Luiz batucam no pote de gelatina com colheres, produzindo sons e ritmos.

Duda e Mathias brincam com a gelatina, tocando-a com a pontinha dos dedos.

Vivi, Mathias e Duda ainda comem gelatina. V passa oferecendo água. Somente os que querem pegam a água.

Hora de subir e fazer a higiene para o sono.

Organização da sala após o sono

\begin{tabular}{|l|l|}
\hline Data & $05 / 11 / 2013$ \\
\hline $\mathbf{N}^{\mathbf{o}}$ registro & 04 \\
\hline Horário & $14 \mathrm{~h} 36 \mathrm{~min}$ às $15 \mathrm{~h} 00 \mathrm{~min}$ \\
\hline
\end{tabular}




\begin{tabular}{|l|}
\hline Pesquisadora: Lídia Godoi \\
\hline Professoras envolvidas: O e MG (coordenadora) \\
\hline Turma: MGI-AB \\
\hline $\begin{array}{l}\text { Crianças presentes: Viviany, Dhara, Ingrid, Maria Eduarda, Mathias, Victor, Eduardo, } \\
\text { Yasmin, Sarah, José Ricardo, Matheus, Vinícius, Giovana, Thiago, Henrique, Sophia, } \\
\text { Marcos, Jeferson, Luiz Gustavo, Lara, Jorge (total de } 21 \text { crianças). }\end{array}$ \\
\hline
\end{tabular}

\begin{tabular}{|l|l|}
\hline Natureza da atividade e materiais & Organização da sala após o sono. \\
\hline $\begin{array}{l}\text { Participação das crianças e } \\
\text { produções coletivas e individuais }\end{array}$ & Todas as crianças. \\
\hline $\begin{array}{l}\text { Comunicação: Adulto-criança / } \\
\text { criança-criança }\end{array}$ & $\begin{array}{l}\text { Adulto-criança: as professoras auxiliamcom a } \\
\text { organização dos colchões, e ajudam as crianças a } \\
\text { colocarem os sapatos. }\end{array}$ \\
\hline $\begin{array}{l}\text { Acontecimentos planejados e } \\
\text { imprevistos }\end{array}$ & \\
\hline
\end{tabular}

\section{Relatório}

Hoje, a professora O está sozinha, pois a professora I está de licença-saúde. A coordenadora MG ficará auxiliando a professora.

As crianças vão aos poucos acordando, colocando os sapatos, guardando os lençóis. Alguns ainda dormem.

Luiz pega o sapato do Jeferson e dá na mão dele:

- Olha aqui, esse é seu.

Aos poucos, as crianças desencapam os colchões e organizam a sala com a ajuda dos adultos.

A chama a atenção de Jorge, que está subindo na barra de ferro:

- Jorge, não precisa ficar fazendo isso pra chamar atenção. Toda hora você faz alguma coisa para chamar atenção.

As crianças que terminam de colocar o sapato vão ao banheiro fazer xixi e lavar as mãos.

Eduardo tira a coberta da Sofia e diz:

- Anda. Tá na hora de acordar.

Algumas crianças ainda estão dormindo, então a MG desceu com uma parte da turma enquanto a $\mathrm{O}$ ficou na sala auxiliando e acordando os demais.

\section{Impressões gerais}

\section{5/11/2013 - IMPRESSÕES GERAIS - MANHÃ}

As crianças são bem autônomas no que diz respeito a cuidar de si e de seus pertences, práticas sociais em que as professoras estão sempre atentas a ensinar e organizar os momentos, de forma a privilegiar a aprendizagem dessas práticas. No brincar livre, como 
sempre a imaginação das crianças dá o tom, elas se organizam, reúnem materiais, retomam as mesmas brincadeiras, ou reinventam-nas, acrescentando outros elementos.

\section{5/11/2013 - IMPRESSÕES GERAIS - TARDE}

Durante a tarde, a ação das professoras no que diz respeito à autonomia ao cuidar de si e dos pertences é a mesma. Abordam-se da mesma forma essas práticas sociais, incentivando as crianças a fazer sozinhas a sua higiene, a colocar seus sapatos e guardar seus pertences. $\mathrm{O}$ brincar livre ocorre de maneira parecida, sem interferências das professoras. As crianças têm total liberdade para investir em suas brincadeiras. Contudo, um olhar mais atento do adulto poderia enriquecer essa brincadeira, providenciando materiais e incentivando as investidas das crianças. 
$18 / 11 / 2013$

Acolhida das crianças

\begin{tabular}{|l|l|}
\hline Data & $18 / 11 / 2013$ \\
\hline $\mathbf{N}^{\mathbf{o}}$ registro & 01 \\
\hline Horário & $08 \mathrm{~h} 00 \mathrm{~min}$ às 08h40min \\
\hline Pesquisadora: Lídia Godoi \\
\hline Professoras envolvidas: P e V \\
\hline Turma: MGI-AB \\
\hline $\begin{array}{l}\text { Crianças presentes: Viviany, Dhara, Ingrid, Maria Eduarda, Mathias, Victor, Eduardo, } \\
\text { Yasmin, Sarah, José Ricardo, Matheus, Vinícius, Giovana, Thiago, Henrique, Sophia, } \\
\text { Marcos, Jeferson, Luiz Gustavo, Lara, Jorge (total de 21 crianças). }\end{array}$ \\
\hline
\end{tabular}

\begin{tabular}{|l|l|}
\hline Natureza da atividade e materiais & $\begin{array}{l}\text { Acolhida / Chamadinha / Higiene - Atividade } \\
\text { permanente / Massinha e moldes para massinha. }\end{array}$ \\
\hline $\begin{array}{l}\text { Participação das crianças e } \\
\text { produções coletivas e individuais }\end{array}$ & $\begin{array}{l}\text { Algumas crianças preferiram ficar na área da } \\
\text { leitura. A maioria ficou envolvida com a } \\
\text { massinha, utilizaram os instrumentos para criar } \\
\text { figuras diversas. }\end{array}$ \\
\hline $\begin{array}{l}\text { Comunicação: Adulto-criança / } \\
\text { criança-criança }\end{array}$ & $\begin{array}{l}\text { Adulto-criança: as professoras recebiam as } \\
\text { crianças enquanto as demais estavam nas áreas } \\
\text { oferecidas. }\end{array}$ \\
\hline $\begin{array}{l}\text { Acontecimentos planejados e } \\
\text { imprevistos }\end{array}$ & $\begin{array}{l}\text { Os momentos foram planejados, não houve } \\
\text { imprevistos. }\end{array}$ \\
\hline
\end{tabular}

\section{Relatório}

Hoje, as professoras $\mathrm{P}$ e $\mathrm{V}$ organizaram um espaço com massa de modelar e instrumentos para utilizar com a massinha. Moldes diversos: borboletas, estrelas, focas, corações.

Luiz:

- Olha, fiz a bolinha.

As crianças fazem uma espécie de folha sobre a massa e, com os moldes, criam objetos distintos.

Mathias:

- Eu fiz uma cobra.

Giovanna:

- Ó, uma estela.

$\mathrm{P}:$

- Luizinho, vamos fazer uma bolinha para guardar e sentar no tapete para fazer achamadinha. 
No tapete, $\mathrm{V}$ canta.

- "Lelelê, lelelâ a boquinha vai fechar".

As crianças acompanham.

A chamadinha (cartaz) está com algumas marcas de durex.

$\mathrm{V}$ :

- Eu estou muito triste, porque alguém estragou o nosso painelzinho de colocar o nome. $\mathrm{O}$ painel que eu e a $\mathrm{P}$ compramos com nosso dinheirinho.

Marcos:

- Foi eu, o Jorge e o Mathias.

V:

- Por que vocês fizeram isso?

Marcos:

- A O deixou a gente brincar.

$\mathrm{V}$ :

- É, mas nós estamos muito tristes. Agora a gente vai tomar café, tem pão e leite, mas só quem quiser pega. Senão, desperdiça a comida.

P:

- Turminha! Os meninos vêm fazer xixi e as meninas ficam no banco.

P:

- Meninos, levantem a tampa do vaso, olhem bem para o "pipi", pra não molhar tudo. Enquanto $\mathrm{P}$ está no banheiro com os meninos, $\mathrm{V}$ canta com as meninas que esperam sua vez no banco.

Para formar a fila para descer para o café, $\mathrm{V}$ e $\mathrm{P}$ cantam a música "Se eu fosse um peixinho". Cada criança que V tira do mar, vai para a fila.

\section{Brincar livre no parque}

\begin{tabular}{|l|l|}
\hline Data & $18 / 11 / 2013$ \\
\hline No $^{\circ}$ registro & 02 \\
\hline Horário & 9 h00min às $10 \mathrm{~h} 15 \mathrm{~min}$ \\
\hline Pesquisadora: Lídia Godoi \\
\hline Professoras envolvidas: P e V \\
\hline Turma: MGI-AB \\
\hline $\begin{array}{l}\text { Crianças presentes: Viviany, Dhara, Ingrid, Maria Eduarda, Mathias, Victor, Eduardo, } \\
\text { Yasmin, Sarah, José Ricardo, Matheus, Vinícius, Giovana, Thiago, Henrique, Sophia, } \\
\text { Marcos, Jeferson, Luiz Gustavo, Lara, Jorge (total de 21 crianças). }\end{array}$ \\
\hline
\end{tabular}

\begin{tabular}{|l|l|}
\hline Natureza da atividade e materiais & Brincar livre no parque - Atividade permanente. \\
\hline $\begin{array}{l}\text { Participação das crianças e produções } \\
\text { coletivas e individuais }\end{array}$ & $\begin{array}{l}\text { As crianças brincam juntas, exploram todo o } \\
\text { espaço do parque e criam suas brincadeiras. }\end{array}$ \\
\hline Comunicação: Adulto-criança / & Adulto-criança: as professoras somente \\
\hline
\end{tabular}




\begin{tabular}{|l|l|}
\hline criança-criança & interferem quando solicitadas. \\
\hline $\begin{array}{l}\text { Acontecimentos planejados e } \\
\text { imprevistos }\end{array}$ & \\
\cline { 2 - 2 } & \\
\hline
\end{tabular}

\section{Relatório}

Duda e Yasmin brincam com alguns vasilhames em um cantinho com barro que se formou devido às chuvas. Com um regador, uma pá e um molde de estrelas, elas brincam de fazer comidinha.

Duda:

- Eu tô fazendo arroz. Yasmin, tem que colocar na panela e mexê assim.

Giovana se aproxima:

- Sai da nossa casa.

Giovana pega um balde e uma pazinha, e entra na brincadeira.

Ela escava um pouco do barro, coloca dentro do balde e mexe.

Duda deixa de lado os objetos e começa mexer o barro com as mãos.

- Nós tamo fazendo bolo!

Giovana:

- Coloca queijo. Um pouco de queijo aqui.

Dhara se aproxima e Duda e Giovana dizem:

- Sai da nossa casa.

Dhara responde:

- Aí tá molhado, Duda.

Com o bolo pronto, Yasmin, Giovana e Duda cantam parabéns.

P se aproxima:

- Maria Eduarda! Não tá molhado aí não?

$P$ não se aproxima. As meninas deixam a brincadeira.

Luiza, Mathias, Marcos e Thiago brincam no...

Experimentam as curvas, andam pelo espaço azul com pistas desenhadas no chão.

Observo Sarah, Giovana, Dhara e Sophia brincando de cachorrinho.

Sarah:

- Vau passar depois vai dormir.

Marcos se aproxima e Giovana o ataca como se fosse um cachorro bravo.

Sarah:

- Toma esse aqui. Um ossinho pra você.

Agora, Giovana é a dona dos cachorros.

Giovana:

- Vem, vamos passear. Olha! Cuidado com o barro.

Sophia:

- Au, au, au!

Giovana faz gestos para chamar os cachorrinhos, bate palmas e estala os dedos.

Sarah:

- Ó Lídia, a gente gosta muito de fazer cachorro.

Giovana para Lara:

- Oi, cachorro!

Lara:

- A gente não consegue andar no seu carro verde.

Os "cachorrinhos" começam a fazer percursos. Vão para debaixo da mesa. 
Giovana, dona dos cachorrinhos, faz carinho na Sarah.

$\mathrm{Na}$ área azul, Luiz, Henrique, Duda, Matheus, Jeferson e Mathias brincam de cachorrinho também.

Eles atacam uns aos outros como se fossem cachorros bravos brigando. Atacam também as crianças que passam no triciclo como fazem os cachorros atrás das motos na rua.

Marcos se aproxima e deita no colo da P.

AC começa a nomear os cachorrinhos:

Lovinho, July, Lalalu.

Lalalu foi o nome dado pela Dhara para ela mesma enquanto "cachorrinha".

Marcos deita-se no colo de $\mathrm{P}$, que faz cafuné em sua barriga.

P finge jogar um osso:

- Vai lobinho, vai lobinho. Cachorro gosta de osso, né?

P brinca com as crianças de jogar osso para que os "cachorrinhos" peguem.

Matheus agora é um cachorro bravo que morde os colegas: Luiz, Henrique e Jeferson. Ele foge.

Hora de entrar para tomar o suco. As professoras chamam.

P:

- Turminha! Vamos às motocas e lavar as mãos para tomar o suco.

Roda de conversa e de leitura

\begin{tabular}{|l|l|}
\hline Data & $18 / 11 / 2013$ \\
\hline $\mathbf{N}^{\mathbf{0}}$ registro & 03 \\
\hline Horário & $10 \mathrm{~h} 15 \mathrm{~min}$ às $10 \mathrm{~h} 45 \mathrm{~min}$ \\
\hline Pesquisadora: Lídia Godoi \\
\hline Professoras envolvidas: P e V \\
\hline Turma: MGI-AB \\
\hline $\begin{array}{l}\text { Crianças presentes: Viviany, Dhara, Ingrid, Maria Eduarda, Mathias, Victor, Eduardo, } \\
\text { Yasmin, Sarah, José Ricardo, Matheus, Vinícius, Giovana, Thiago, Henrique, Sophia, } \\
\text { Marcos, Jeferson, Luiz Gustavo, Lara, Jorge (total de 21 crianças). }\end{array}$ \\
\hline
\end{tabular}

\begin{tabular}{|l|l|}
\hline Natureza da atividade e materiais & $\begin{array}{l}\text { Roda de conversa e de leitura - Atividade } \\
\text { permanente. }\end{array}$ \\
\hline $\begin{array}{l}\text { Participação das crianças e } \\
\text { produções coletivas e individuais }\end{array}$ & $\begin{array}{l}\text { As crianças conversam e expressam suas opiniões } \\
\text { livremente. }\end{array}$ \\
\hline $\begin{array}{l}\text { Comunicação: Adulto-criança / } \\
\text { criança-criança }\end{array}$ & $\begin{array}{l}\text { Adulto-criança: as professoras conduzem a } \\
\text { conversa, contam histórias e convidam as crianças } \\
\text { a participar. }\end{array}$ \\
\hline $\begin{array}{l}\text { Acontecimentos planejados e } \\
\text { imprevistos }\end{array}$ & O momento foi planejado, não houve imprevisto. \\
\hline
\end{tabular}




\section{Relatório}

No retorno para a sala, as crianças guardam suas blusas sozinhas nas mochilas. $\mathrm{V}$ :

- Turminha, hoje é o dia da leitura, porque hoje é dia de vocês falarem do livro que vocês leram em casa. Eu trouxe esta história que eu falei que ia pegar lá na biblioteca de onde eu trabalho.

V canta:

- "Lê, Lê, Lê, trá, lá, lá, uma história eu vou contar". E inicia a história "Cinderela e suas irmãs".

Enquanto $\mathrm{V}$ lê a história, $\mathrm{P}$ organiza alguns materiais na mesa do professor.

Nessa história, Cinderela desobedece ao padrinho e é transformada em uma abóbora. $\mathrm{V}$ :

- Viu o que aconteceu, ela não obedeceu ao padrinho, tem que obedecer.

$\mathrm{V}$ :

- Agora vamos ver as histórias, e quem trouxe de volta para ler para a turma.

P:

- Zé, quem leu esse livrinho?

Zé:

- Eu.

P:

- E como chama?

Zé:

- As coisas que eu gosto.

$\mathrm{V}$ :

- Quem leu para você?

Zé:

- A mamãe.

As pastas nas quais as crianças levam os livros são identificadas com a foto da própria criança.

P segue:

- Marcos, como se chama essa história?

Marcos:

- É o navio que levava os animais.

$\mathrm{P}$ :

- Quem leu pra você, Marcos?

Marcos:

- Mamãe.

$\mathrm{P}$ :

- E essa pasta?

Marcos:

- É do Thiago.

P:

- Quem leu esse livro pra você?

Thiago:

- A mamãe.

P:

- Esse livro tem bastante coisa que dá até fome. Lembra quando contei pra vocês?

Sarah:

- É, tem bastante comida. 
P segue apresentando os livros que foram levados para que a turma fale sobre eles.

É interessante que todos sabem o número dos livros. Eles conhecem os títulos, pois são apresentados toda sexta e retornam na segunda. Os títulos circulam tanto entre a turma, que eles já conhecem a maioria das histórias.

Sarah:

- Eu já levei esse. É do tatu.

Lara:

- Eu levei o livrinho pra minha casa.

P:

- Quem levou esse?

Sarah:

- Eu.

P:

- Como ele chama?

Sarah:

- Trava-língua.

$\mathrm{P:}$

- O peito do pé do Pedro é preto (P fala alguns trava-línguas para a turma).

P pergunta o nome do livro que Vinícius levou.

Vinícius:

- Árvore, sorvete.

P:

- Muito bem! Comenta com a V: Para quem não falava nada, né?

\section{Organização da sala após o sono}

\begin{tabular}{|l|l|}
\hline Data & $18 / 11 / 2013$ \\
\hline $\mathbf{N}^{o}$ registro & 04 \\
\hline Horário & $14 \mathrm{~h} 35 \mathrm{~min}$ às 15h00min \\
\hline Pesquisadora: Lídia Godoi \\
\hline Professoras envolvidas: O eI \\
\hline Turma: MGI-AB \\
\hline $\begin{array}{l}\text { Crianças presentes: Viviany, Dhara, Ingrid, Maria Eduarda, Mathias, Victor, Eduardo, } \\
\text { Yasmin, Sarah, José Ricardo, Matheus, Vinícius, Giovana, Thiago, Henrique, Sophia, } \\
\text { Marcos, Jeferson, Luiz Gustavo, Lara, Jorge (total de 21 crianças). }\end{array}$ \\
\hline
\end{tabular}

\begin{tabular}{|l|l|}
\hline Natureza da atividade e materiais & Atividade permanente. \\
\hline $\begin{array}{l}\text { Participação das crianças e } \\
\text { produções coletivas e individuais }\end{array}$ & $\begin{array}{l}\text { A turma colabora com a professora na organização } \\
\text { da sala, conversam entre si, ajudam uns aos na } \\
\text { hora de colocar os sapatos. }\end{array}$ \\
\hline $\begin{array}{l}\text { Comunicação: Adulto-criança / } \\
\text { criança-criança }\end{array}$ & $\begin{array}{l}\text { Adulto-criança: as professoras elogiam as crianças, } \\
\text { e encorajam-nas a participar. }\end{array}$ \\
\hline $\begin{array}{l}\text { Acontecimentos planejados e } \\
\text { imprevistos }\end{array}$ & \\
\hline
\end{tabular}




\section{Relatório}

Todas as crianças, com exceção do Marcos, estão dormindo. Por conta do horário de tomar o leite, O terá de acordá-los.

Ela abre todas as janelas para clarear a sala.

Uma ATE auxilia as crianças na organização dos colchões e também guardar os lençóis. As crianças colocam os tênis e dirigem-se ao banheiro. Como de costume, elas colocam seus sapatos sozinhos; quando necessário, as professoras auxiliam.

Henrique procura seu tênis.

- Cadê meu tênis?

Zé responde:

- Tá aqui.

Henrique:

- Então joga.

Zé joga o tênis para Henrique, que reponde:

- Parabéns!

$\mathrm{O}$ :

- Marcos, faz um favor pra mim?

Marcos:

- O quê?

$\mathrm{O}$ :

- Guarda a mochila do Zé.

Em uma rodinha, Jeferson, Luiz e Mathias conversam sobre suas meias.

Mathias:

- A minha é do Mickey Mouse.

Mathias:

- Olha, a sua é do Ben 10.

Luiz, sem querer, bate de leve com o cotovelo no Jeferson.

Luiz:

- Desculpa.

Jeferson:

- Desculpa nada.

Enquanto as crianças se organizam, chegam três crianças do MG 2 (crianças entre 4 anos e 4 anos e 11 meses). $\mathrm{O}$ as recebe dizendo boa tarde.

Em roda, $\mathrm{O}$ conversa com as crianças.

- Oi, gente, tudo bem? O que vocês fizeram hoje de manhã?

Marcos:

- Ficamos no parque.

Vivi:

- Brincamos de massinha.

$\mathrm{O}$ :

- Hoje, a gente vai assistir a um filme. Tem "Up altas aventuras" e "Bolt".

Luiz:

- Aventura.

Sarah:

- Eu quero de aventura.

O:

- Todo mundo quer assistir "Up altas aventuras"? 
Em coro, respondem que sim.

$\mathrm{O}$ :

- Só que antes a gente vai brincar no parque.

$\mathrm{O}$ apresenta as crianças que vieram da outra sala.

$\mathrm{O}$ :

- A Isabela, o Davi e o Rafael são nossas visitas. Vamos cuidar bem deles.

\section{Brincar livre no parque}

\begin{tabular}{|l|l|}
\hline Data & $18 / 11 / 2013$ \\
\hline $\mathbf{N}^{\mathbf{o}}$ registro & 05 \\
\hline Horário & $15 \mathrm{~h} 10 \mathrm{~min}$ às 16h30min \\
\hline Pesquisadora: Lídia Godoi \\
\hline Professoras envolvidas: O e I \\
\hline Turma: MGI-AB \\
\hline $\begin{array}{l}\text { Crianças presentes: Viviany, Dhara, Ingrid, Maria Eduarda, Mathias, Victor, Eduardo, } \\
\text { Yasmin, Sarah, José Ricardo, Matheus, Vinícius, Giovana, Thiago, Henrique, Sophia, } \\
\text { Marcos, Jeferson, Luiz Gustavo, Lara, Jorge (total de 21 crianças). }\end{array}$ \\
\hline
\end{tabular}

\begin{tabular}{|l|l|}
\hline Natureza da atividade e materiais & Brincar livre no parque - Atividade permanente. \\
\hline $\begin{array}{l}\text { Participação das crianças e } \\
\text { produções coletivas e individuais }\end{array}$ & $\begin{array}{l}\text { As crianças brincam juntas, exploram todo o } \\
\text { espaço do parque e criam suas brincadeiras. }\end{array}$ \\
\hline $\begin{array}{l}\text { Comunicação: Adulto-criança / } \\
\text { criança-criança }\end{array}$ & $\begin{array}{l}\text { Adulto-criança: as professoras somente interferem } \\
\text { quando solicitadas. }\end{array}$ \\
\hline $\begin{array}{l}\text { Acontecimentos planejados e } \\
\text { imprevistos }\end{array}$ & \\
\hline
\end{tabular}

\section{Relatório}

No parque, estão as duas salas de B2 e os dois mini grupos.

Zé e Mathias brincam juntos. Eles dão várias voltas no parque. O Mathias empurra o triciclo do Zé. Vinícius, Yasmin e Giovana tentam acertar a bola no cesto junto com um grupo de crianças da outra turma que estão envolvidas em um jogo de basquete.

$\mathrm{Na}$ área azul, Yasmin, Darah, Matheus e Vinícius tentam escalar as grades.

Matheus e Vinícius tentam escalar as grades.

Mathias, Jorge, Thiago e Matheus andam com os triciclos sobre o percurso desenhado no chão. Matheus carrega Dhara na garupa.

Matheus se aproxima de mim e diz:

- Tô andando de carro. O Zé também tá andando de bicicleta.

Mathias no triciclo tenta pegar o Luiz que corre na frente. Marcos, Luiz, Mathias e Zé 
brincam de pegador. Todos de triciclo tentam pegar o Luiz que corre na frente.

As crianças experimentam toda a velocidade que o brinquedo pode proporcionar. Não se atêm ao percurso desenhado no chão, criando seu próprio percurso, e apostam corrida entre si.

A diversão é correr com o triciclo o máximo possível, experimentando a sensação causada pela velocidade. E, no final, uma derrapada.

Percebo que essa brincadeira é bem apreciada pelas crianças, tanto no horário da manhã como durante a tarde. Elas passam horas envolvidas.

Com os espaços abertos entre o parque e a área azul, o espaço se amplia significativamente, o que favorece a movimentação das crianças que transitam de uma área a outra.

No tanque de areia, Lara e Thiago brincam com os baldinhos, fazendo marcas na areia, enchendo e esvaziando os baldes.

Lara faz um "bolo" com a areia e depois canta parabéns pra você.

Vivi prefere subir e descer no escorregador.

Yasmin, Jeferson e Sarah brincam no túnel com pás e alguns baldinhos.

Sarah:

- Eu tô fazendo bolo. É para o cachorrinho.

Percebo que Lara e Jeferson, na verdade, são os cachorrinhos da Sarah.

Sarah:

- Vai brincar, cachorrinho. Eu já vou terminar sua comida.

Hora do jantar. As professoras chamam as crianças para estacionar as motocicletas e lavar as mãos para o jantar. Depois do jantar, as crianças irão assistir a um filme enquanto esperam pelos pais.

\section{Impressões gerais}

\section{8/11/2013 - IMPRESSÕES GERAIS - MANHÃ}

A acolhida foi organizada, possibilitando que as crianças pudessem escolher entre explorar massinha, ficar na área de leitura ou mesmo sentar-se e não fazer nada. P esteve mais atenta à área da massinha, utilizando os moldes e mostrando para as crianças algumas maneiras de utilizá-los, enquanto $\mathrm{V}$ recebia as crianças.

No parque, as professoras estiveram observando as crianças nos diferentes espaços. $\mathrm{O}$ que prevaleceu durante o parque foram as iniciativas das crianças, a liberdade para brincar como e com quem quisessem. Nos momentos de higiene, as professoras orientaram as crianças quando necessário. $\mathrm{Na}$ roda de leitura, as crianças participaram, expondo suas opiniões, e falavam bastante sobre as histórias que leram.

\section{8/11/2013 - IMPRESSÕES GERAIS - TARDE}

Fiquei menos à tarde hoje, pelas restrições no horário. As crianças colaboraram na organização da sala. Isso já é uma prática consolidada entre as crianças, e os adultos criam condições para tal. Nesse momento, as crianças aprendem práticas sociais, como organizar seu próprio espaço, e também colaboram entre si na arrumação de suas coisas. 
$03 / 12 / 2013$

Brincar livre no parque

\begin{tabular}{|l|l|}
\hline Data & $03 / 12 / 2013$ \\
\hline $\mathbf{N}^{\mathbf{o}}$ registro & 01 \\
\hline Horário & $09 \mathrm{~h} 00 \mathrm{~min}$ às 10h00min \\
\hline Pesquisadora: Lídia Godoi \\
\hline Professoras envolvidas: P e V \\
\hline Turma: MGI-AB \\
\hline $\begin{array}{l}\text { Crianças presentes: Viviany, Dhara, Mara Eduarda, Mathias, Vitor, Eduardo, Yasmin, } \\
\text { Sarah, José Ricardo, Matheus, Vinícius, Giovana, Thiago, Henrique, Sophia, Marcos, } \\
\text { Jeferson, Luiz Gustavo, Lara, Jorge (total de 20 crianças). }\end{array}$ \\
\hline
\end{tabular}

\begin{tabular}{|l|l|}
\hline Natureza da atividade e materiais & Brincar livre no parque - Atividade permanente. \\
\hline $\begin{array}{l}\text { Participação das crianças e } \\
\text { produções coletivas e individuais }\end{array}$ & Todas as crianças participam. \\
\hline $\begin{array}{l}\text { Comunicação: Adulto-criança / } \\
\text { criança-criança }\end{array}$ & $\begin{array}{l}\text { Adulto-criança: as professoras auxiliam as } \\
\text { crianças quando necessário. } \\
\text { Criança-criança: as crianças conversam entre si, } \\
\text { se organizam para brincar e criam suas } \\
\text { brincadeiras. }\end{array}$ \\
\hline $\begin{array}{l}\text { Acontecimentos planejados e } \\
\text { imprevistos }\end{array}$ & Não há um planejamento prévio. \\
\hline
\end{tabular}

\section{Relatório}

Quando cheguei, as crianças estavam no parque. Havia triciclos, motocas e baldinhos para brincar na areia.

A professora $\mathrm{V}$ estava com outra professora, pois a $\mathrm{P}$ precisou faltar.

As crianças circulam pelo parque livremente, brincam sozinhas ou em grupo, escolhem materiais e espaços.

Algumas crianças brincam nos triciclos. Vivi, Vitor, Giovana e Matheus, estão apostando corrida, testam a velocidade do brinquedo. Experimentam fazer curvas. Utilizam o pé para ganhar impulso no brinquedo. Giovana, Vitor e Vivi param e iniciam uma conversa.

Giovana:

- Vitor, você lava louça?

Vitor:

- Não, só minha mãe.

Vivi:

- Eu limpo a casa da minha mãe. Passo roupa. 
Vivi fala para Vitor:

- Olha, você não pega arroz.

Vitor se retira da conversa e sai pedalando para o outro lado do parque:

- Tchau, eu vou na praia.

Sarah, Henrique e Matheus brincam juntos na casinha do brincam juntos na casinha do Tarzan. Eles organizaram uma brincadeira em que o Matheus é uma espécie de monstro e Sarah e Henrique precisam fugir dele.

Henrique:

- Vai embora, monstro verde!

Lembro-me de P ter contado essa história "Vai embora grande monstro verde". Henrique, em sua brincadeira, faz referência à ela.

Sarah, ao perceber uma professora fazendo bolinha de sabão do outro lado, perto das balanças, corre até lá para pegar as bolinhas.

Matheus e Henrique continuam brincando.

Matheus:

- Você tem que fugir. Eu vou pegar! AHHHH!!!

Sarah retoma a brincadeira com Henrique e Matheus.

Sarah:

- Henrique, vamos descer! (da casinha) Tem que esconder, vem!

As torneiras que foram colocadas no parque já estão funcionando. De vez em quando, as crianças se aproximam, toma água, ou simplesmente ficam um tempo lavando as mãos. Existem duas mesas com cadeiras no parque, elas estão dificultando um pouco o acesso das crianças.

Hora de tomar suco. V chama as crianças.

- Pessoal, a turma do peixinho senta aqui perto da parede. Tirem o sapato para limpar a areia.

\section{Higiene}

\begin{tabular}{|l|l|}
\hline Data & $03 / 12 / 2013$ \\
\hline $\mathbf{N}^{\mathbf{o}}$ registro & 02 \\
\hline Horário & $10 \mathrm{~h} 00 \mathrm{~min}$ às $10 \mathrm{~h} 15 \mathrm{~min}$ \\
\hline Pesquisadora: Lídia Godoi \\
\hline Professoras envolvidas: P e V \\
\hline Turma: MGI-AB \\
\hline $\begin{array}{l}\text { Crianças presentes: Viviany, Dhara, Mara Eduarda, Mathias, Vitor, Eduardo, Yasmin, } \\
\text { Sarah, José Ricardo, Matheus, Vinícius, Giovana, Thiago, Henrique, Sophia, Marcos, } \\
\text { Jeferson, Luiz Gustavo, Lara, Jorge (total de } 20 \text { crianças). }\end{array}$ \\
\hline
\end{tabular}

\begin{tabular}{|l|l|}
\hline Natureza da atividade e materiais & Atividade permanente envolvendo higiene. \\
\hline $\begin{array}{l}\text { Participação das crianças e } \\
\text { produções coletivas e individuais }\end{array}$ & Todas as crianças participam. \\
\hline $\begin{array}{l}\text { Comunicação: Adulto-criança / } \\
\text { criança-criança }\end{array}$ & $\begin{array}{l}\text { Adulto-criança: as professoras auxiliam as } \\
\text { crianças quando necessário e orientam quanto ao }\end{array}$ \\
\hline
\end{tabular}




\begin{tabular}{|l|l|}
\hline & uso do banheiro. \\
\hline $\begin{array}{l}\text { Acontecimentos planejados e } \\
\text { imprevistos }\end{array}$ & Não há um planejamento prévio. \\
\hline
\end{tabular}

\section{Relatório}

As crianças passam no banheiro para lavar as mãos. Há sabão e papel para secar na carteira delas, o que facilita para que elas se lavem sozinhas.

Todos fazem o movimento de pegar o sabão, lavar as mãos, secar e depois jogar o papel na lixeira.

Durante o suco, as professoras distribuem os copos para as crianças que estão sentadas esperando. Ao terminar de tomar o suco, cada um leva seu copo até a janelinha da cozinha.

\section{Roda de história e massinha}

\begin{tabular}{|l|l|}
\hline Data & $03 / 12 / 2013$ \\
\hline $\mathbf{N}^{\mathbf{0}}$ registro & 03 \\
\hline Horário & $10 \mathrm{~h} 15 \mathrm{~min}$ às 10h50min \\
\hline Pesquisadora: Lídia Godoi \\
\hline Professoras envolvidas: V e S. \\
\hline Turma: MGI-AB \\
\hline $\begin{array}{l}\text { Crianças presentes: Viviany, Dhara, Mara Eduarda, Mathias, Vitor, Eduardo, Yasmin, } \\
\text { Sarah, José Ricardo, Matheus, Vinícius, Giovana, Thiago, Henrique, Sophia, Marcos, } \\
\text { Jeferson, Luiz Gustavo, Lara, Jorge (total de 20 crianças). }\end{array}$ \\
\hline
\end{tabular}

\begin{tabular}{|l|l|}
\hline Natureza da atividade e materiais & $\begin{array}{l}\text { Atividade dirigida / Roda de história e atividade } \\
\text { com massinha. }\end{array}$ \\
\hline $\begin{array}{l}\text { Participação das crianças e produções } \\
\text { coletivas e individuais }\end{array}$ & Todas as crianças participam. \\
\hline $\begin{array}{l}\text { Comunicação: Adulto-criança / } \\
\text { criança-criança }\end{array}$ & $\begin{array}{l}\text { Adulto-criança: as crianças interagem entre si e } \\
\text { com as professoras, fazendo questionamentos, } \\
\text { falando sobre suas experiências. }\end{array}$ \\
\hline $\begin{array}{l}\text { Acontecimentos planejados e } \\
\text { imprevistos }\end{array}$ & Tudo ocorreu como planejado. \\
\hline
\end{tabular}

\section{Relatório}

$\mathrm{V}$ :

- Gente, vamos subir para fazer a roda de história.

$\mathrm{M}$ instalou-se no lactário com a turma.

Antes de iniciar, V canta "Lê, lê, lê, la, la, la, uma história eu vou contar". 
V começa apresentando o autor e o ilustrador da história.

Essa história chama “A história da tartaruga". Quem escreveu foi o Lêdo Ivo, e quem fez os desenhos foi Isabel Paiva.

Depois de contar a história, $\mathrm{V}$ explica.

- Agora a V vai distribuir massinha, a gente vai poder construir o que quiser. Lá no CEU (onde $\mathrm{V}$ trabalha no outro período), tem criança que fez a folha, outra fez a tartaruga, a casinha dela.

A professora $S$ vai pegar as forminhas pra gente construir coisas com a massinha.

Durante a brincadeira, Duda mordeu o braço da Vivi, porque queria o brinquedo dela. $\mathrm{V}$ chama a sua atenção:

- Pode abraçar a Viviane, faz massagem no braço dela e pede desculpas.

Depois, V se dirige a Duda:

- Duda, a V já conversou com você, senta aqui comigo, já conversei com sua mãe, não faça isso, agora vai brincar, mas sem morder.

Duda senta-se à mesa e vai brincar.

Hora de guardar.

$\mathrm{V}$ :

- Pessoal, vamos guardar, vamos juntar as massinhas da mesma cor e colocar no pote. Vai Gigi, me dá a rosa. Gigi entrega a massinha rosa para V.

As crianças vão organizando a massinha por cor e aos poucos guardam tudo com a ajuda de $\mathrm{V}$ e $\mathrm{S}$.

Ao terminar, a turma se dirige ao banheiro para lavar as mãos, e, em seguida, almoçar, escovar os dentes e depois dormir.

\section{Banho de bacia}

\begin{tabular}{|l|l|}
\hline Data & $03 / 12 / 2013$ \\
\hline $\mathbf{N}^{\mathbf{0}}$ registro & 04 \\
\hline Horário & $14 \mathrm{~h} 45 \mathrm{~min}$ às 14h50min \\
\hline Pesquisadora: Lídia Godoi \\
\hline Professoras envolvidas: O e I. \\
\hline Turma: MGI-AB \\
\hline $\begin{array}{l}\text { Crianças presentes: Viviany, Dhara, Mara Eduarda, Mathias, Vitor, Eduardo, Yasmin, } \\
\text { Sarah, José Ricardo, Matheus, Vinícius, Giovana, Thiago, Henrique, Sophia, Marcos, } \\
\text { Jeferson, Luiz Gustavo, Lara, Jorge (total de 20 crianças). }\end{array}$ \\
\hline
\end{tabular}

\begin{tabular}{|l|l|}
\hline Natureza da atividade e materiais & Atividade esporádica - Banho de bacia. \\
\hline $\begin{array}{l}\text { Participação das crianças e } \\
\text { produções coletivas e individuais }\end{array}$ & Todas as crianças participam. \\
\hline $\begin{array}{l}\text { Comunicação: Adulto-criança / } \\
\text { criança-criança }\end{array}$ & $\begin{array}{l}\text { Adulto-criança: as professoras auxiliam as } \\
\text { crianças quando necessário. } \\
\text { Criança-criança: as crianças conversam entre si. }\end{array}$ \\
\hline
\end{tabular}




\begin{tabular}{|l|l|}
\hline $\begin{array}{l}\text { Acontecimentos planejados e } \\
\text { imprevistos }\end{array}$ & Não há um planejamento prévio. \\
\hline
\end{tabular}

\section{Relatório}

Subo as escadas para ir até a sala onde está a turma. Encontro as crianças no corredor, todas vestidas somente com cuecas e calcinhas.

O me avisa que hoje elas irão brincar com água. As crianças cantam e conversam, pulam, dançam.

A turminha desce com a professora I para tomar o leite e, em seguida, ir para o banho de piscina. Em fila, as crianças pegam o seu copo de leite e sentam-se à mesa (estão sentadas na mesma mesa que sentam pela manhã do lado direito, e não no lado esquerdo, onde sentavam anteriormente).

$\mathrm{Na}$ área azul, as professoras organizaram algumas bacias e mangueira. As crianças utilizam a banheira como se fossem piscinas.

Yasmin e Tiago, embora vestidos adequadamente para a brincadeira, preferem somente observar.

As professoras ficam com as mangueiras e, em alguns momentos, permitem que as crianças manuseiem. Yasmin não resiste e entra na brincadeira.

Marcos achou um potinho perdido no espaço da brincadeira e começa a utilizá-lo para levar água de um lugar a outro.

Giovana encontra uma toalha e utiliza para tomar sol.

Ao perceber, I diz:

- Pessoal, quem vai querer toalha para tomar um solzinho?

Eu me aproximo de Yasmin, Mathias e Giovana, que já vai logo dizendo:

- Eu tô tomando sol.

Nesse espaço, só se escutam gritinhos e gargalhadas.

Duda e Jeferson estão dentro de uma banheira. Marcos enche o potinho que estava

brincando. Vai na direção de Jeferson e Duda. Ao que Duda alerta Jeferson:

- Cuidado! O lobo!

As bacias se transformam em cabana para se defender do lobo.

As crianças brincam na água, e, quando cansam, vão relaxar nas toalhas.

Só agora o Thiago entra na brincadeira, 30 minutos após ter começado.

Marcos e Luiz estão envolvidos em fazer movimentos circulares com as mãos na bacia de água.

Thiago se aproxima para brincar com eles.

Marcos:

- Sai, você não sabe fazer. A gente somos adultos, né, Luiz (no imaginário infantil, já está impressa a ideia de incompetência).

Como se aproxima a hora do jantar, as professoras se organizam da seguinte forma: I leva um grupo de crianças para trocar na sala e $\mathrm{O}$ permanece na brincadeira com o resto da turma, uma agente de apoio as auxilia, subindo as crianças.

Só as crianças que querem sobem para trocar, quem não quiser, permanece brincando.

\section{Jantar}

\section{Data} $03 / 12 / 2013$ 


\begin{tabular}{|l|l|}
\hline $\mathbf{N}^{\mathbf{o}}$ registro & 05 \\
\hline Horário & $16 \mathrm{~h} 30 \mathrm{~min}$ às $16 \mathrm{~h} 55 \mathrm{~min}$ \\
\hline Pesquisadora: Lídia Godoi \\
\hline Professoras envolvidas: O e I. \\
\hline Turma: MGI-AB \\
\hline $\begin{array}{l}\text { Crianças presentes: Viviany, Dhara, Ingrid, Maria Eduarda, Mathias, Victor, Eduardo, } \\
\text { Yasmin, Sarah, José Ricardo, Matheus, Vinícius, Giovana, Thiago, Henrique, Sophia, } \\
\text { Marcos, Jeferson, Luiz Gustavo, Lara, Jorge (total de 21 crianças). }\end{array}$ \\
\hline
\end{tabular}

\begin{tabular}{|l|l|}
\hline Natureza da atividade e materiais & Atividade permanente - Alimentação. \\
\hline $\begin{array}{l}\text { Participação das crianças e } \\
\text { produções coletivas e individuais }\end{array}$ & Todas as crianças participam. \\
\hline $\begin{array}{l}\text { Comunicação: Adulto-criança / } \\
\text { criança-criança }\end{array}$ & $\begin{array}{l}\text { Adulto-criança: as professoras auxiliam as } \\
\text { crianças quando necessário. } \\
\text { Criança-criança: as crianças conversam entre si. }\end{array}$ \\
\hline $\begin{array}{l}\text { Acontecimentos planejados e } \\
\text { imprevistos }\end{array}$ & Não há um planejamento prévio. \\
\hline
\end{tabular}

\section{Relatório}

O acompanha as crianças ao banheiro, auxiliando-as a lavar as mãos. As crianças lavam e secam as mãos sozinhas.

Descemos para o jantar. Em fila, as crianças pegam seus pratos e dirigem-se à mesa. À tarde, elas utilizam a mesa que fica do lado oposto ao da mesa da manhã. Elas pegam o prato e escolhem o lugar da mesa que desejam sentar-se.

O para Eduarda:

- Comi sua comida!!

O caminha em volta da mesa, auxiliando as crianças que não querem comer.

O:

- Du, come um pouquinho pra poder limpar o prato. MG conversa com E, a professora da outra turma, que também está no refeitório.

As crianças que realmente não querem comer limpam o prato, jogando os restos na lixeira. Antes de jogar, as crianças perguntam para a $\mathrm{O}$ se pode.

Lara:

- Pode levar?

$\mathrm{O}$ :

- Come essa última colherada. Só mais essa, daí você pode ir limpar.

O insiste bastante para que as crianças comam.

A sobremesa é colocada sobre a mesa. Quem quer pega.

Ingrid:

- Eu não quero.

Assim como de manhã, as crianças escolhem comer ou não a sobremesa.

A água é servida para aqueles que desejam, da mesma maneira que a sobremesa. 


\section{Impressões gerais}

\section{3/12/2013 - IMPRESSÕES GERAIS - MANHÃ}

Observar a brincadeira livre das crianças tem possibilitado conhecê-las, conhecer seus costumes, o que vivenciam e sua cultura, que se mistura à cultura adulta revelando uma nova maneira de ser, estar e brincar. Durante a roda de história e o trabalho com massa de modelar, percebi algo mais direcionado, ou seja, dever-se-ia ouvir uma história e depois produzir algo. O nível de autonomia das crianças na realização do trabalho consistiu unicamente em definir que moldes usar e a cor da massinha. Suas produções ficaram limitadas, uma vez que a quantidade de massa era insuficiente e o tempo limitado.

\section{3/12/2013 - IMPRESSÕES GERAIS - TARDE}

O banho de bacia foi algo que deixou as crianças muito felizes. As professoras as deixaram livres para explorar a água e as bacias como quisessem, e, assim, alguns fizeram as bacias de piscina. Em alguns momentos, as crianças trazem elementos da cultura adulta. Um exemplo disso pôde ser observado quando a Duda estendeu uma toalha no chão para tomar sol.

Nos momentos de alimentação e higiene, as professoras estão sempre acompanhando as crianças e orientando-as quando necessário. Incentivam as crianças a comer, contudo, não obrigam.

\section{APÊNDICE H - Roteiro de entrevista individual com a Diretora}

\section{Identificação:}

Identifique-se como você quiser, falando minimamente: seu nome, idade, nível de formação e experiências profissionais.

\section{Sobre o dia a dia profissional:}

1) Relate seu dia a dia no CEI, explicitando como ocorrem as comunicações entre as docentes e a gestão (diretora e coordenadora pedagógica) e as gestoras?

2) Como avalia o trabalho pedagógico da unidade? O que está bom e o que precisa melhorar em sua opinião?

3) Como você apoia os professores na realização de suas práticas?

\section{Ser diretora de CEI:}

1) No trabalho desenvolvido no CEI, o que traz satisfação e o que traz frustração?

2) O que gosta e o que não gosta? 
3) O que julga ser atribuição sua?

4) Como diretora? O que falta? O que já está consolidado? Como gostaria que fosse?

\section{Sobre o processo de formação dentro do CEI:}

1) Como surgiu o projeto de formação (PEA) esse ano?

2) Como é planejado?

3) Como ocorre?

4) Qual é a relevância?

5) Que impactos você consegue perceber na prática com as crianças?

6) Existe espaço para a troca de experiências?

7) O que falta? O que já se consolidou? Como gostaria que fosse?

\section{Projeto político-pedagógico:}

1) Que importância assume para a instituição como um todo?

2) Como é pensado e elaborado?

3) Qual é o nível de participação das famílias, profissionais e crianças?

4) Em que medida as crianças e suas famílias são consideradas?

5) Na sua percepção, que relação há entre o proposto e o realizado na prática?

\section{Sobre os tempos e espaços:}

1) Com base em que princípios é organizado o trabalho pedagógico da unidade?

2) Fale um pouco sobre a rotina do CEI e a forma como ela se organiza. Quais aspectos considera importantes nessa rotina?

3) Como as crianças são consideradas na organização dos tempos e espaços da instituição?

4) No que diz respeito à rotina: o que pode melhorar? O que falta? Como gostaria que fosse organizada?

\section{Sobre a prática pedagógica:}

1) O que pensa sobre a organização dos tempos e espaços nesta instituição?

2) Como é pensado o projeto político-pedagógico da unidade?

3) Em que medida o planejamento do trabalho com o agrupamento relaciona-se ao projeto da unidade?

4) Em sua opinião, quais os momentos da rotina diária do CEI que você julga mais marcantes? Por quê? 
5) Como esses momentos aparecem em seu planejamento?

6) Como você concebe a rotina em seu planejamento? Em que elementos você se apoia?

7) Em que você pensa ao planejar seu trabalho?

8) Em que medida você consegue perceber a participação da criança e das famílias em seu processo de planejar?

9) Como o seu planejamento se encontra com os planejamentos de suas colegas do mesmo agrupamento?

10) Como vocês se organizam para planejar as ações para o mesmo agrupamento? Existe um planejamento comum para o agrupamento?

11) Em que medida você e sua parceira de trabalho conseguem concretizar o que planejaram para o período? Que dificuldades você encontra no desenvolvimento daquilo que planejaram?

12) Como são tratados os imprevistos em seu planejamento?

13) Como as professoras dos dois períodos trocam informações?

14) Como trocam experiências de práticas? 


\section{APÊNDICE I - Entrevista com a diretora}

Meu nome é M, trabalho com educação infantil desde de 1982, estou a seis anos com uma sala de EJA no período da noite, fiquei seis anos como diretora do CEI aqui, também fui coordenadora pedagógica por dois anos em outro CEI . Sou formada em pedagogia, pela FE-USP e fiz magistério.

Gostaria que você falasse sobre o seu dia a dia no CEI, explicitando como ocorria a comunicação entre você, as professoras e a coordenadora pedagógica.

Bom, no dia a dia eu tinha bastante contato com os professores, pois, de manhã eu fazia PEA com a turma da manhã, a tarde no horário que os professores chegam eu sempre estava na escola, menos ao final da tarde, pois eu ficava apenas até 15:30, tinha livro de comunicado, os comunicados mais importantes iam para o livro de comunicado. Com a coordenadora, a gente tinha contato direto, ano passado especificamente nós tivemos problemas na questão da comunicação por conta dos nossos horários, eu ficava apenas de manhã e ela apenas no período da tarde, e acontecia que ela chegava e tinha que resolver alguma questão urgente e nós não conseguíamos conversar por conta disso e por que ela não tinha contato com as pessoas da manhã, então, o que acontecia é que as vezes ela tinha que resolver algo mais urgente com as professoras da manhã ou passar alguma informação para elas, então, meu contato com ela não poderia ser feito neste horário pois, ela ficava pouquíssimo tempo com os professores da manhã e esse era o tempo que ela tinha para correr nas salas para perguntar ou informar alguma coisa pois, as meninas já iriam sair, era um horário complicado, o pior horário e também de almoço, então ela chegava num horário muito ruim para as pessoas da manhã e as professoras não gostavam das interferências por que achavam que atrapalhava muito, pois, era um horário de pico, precisava fazer a higiene das crianças, dar o almoço, colocar para dormir, então era o horário considerado de maior intensidade, a gente acabava e já era o horário de almoço, ou meu, ou dela. E muitas vezes ela saia para almoçar e praticamente era a hora de eu ir embora, então acabou dificultando, acho que isso dificultou muito a comunicação, e se a gente precisasse conversar mesmo, eu ia muito alem do meu horário para poder ficar lá para poder falar alguma coisa e nem sempre era possível. Durante a tarde também eram os horários que eu saia para a DRE 
para entregar documento as vezes dava para esperar e as vezes não, então eu acho que os outros anos foram melhores, ela ficava alguns dias de manhã, eu alguns dias de tarde e dava mais certo, a comunicação ficava melhor. Então, houve muitos problemas por conta dessa confusão com os horários.

E eu queria saber como você avalia o trabalho pedagógico da unidade, o que estava bom e o que precisava melhora na sua opinião.

De uma maneira geral, havia um comprometimento das pessoas, foi um dos lugares que eu passei que era levado mais a sério o que era feito, um trabalho de seriedade mesmo. Muito embora, não ser unânime, não ser aquilo de cem por cento, pois, é difícil se encontrar mesmo, mas, a grande maioria tem um comprometimento com o trabalho pedagógico, acho que o que faltava não era uma questão pedagógica, e sim uma questão afetiva, pois, eu sou uma pessoa muito afetiva e em alguns momentos, em algumas profissionais, faltava um pouco mais de afetividade. Não era uma questão pedagógica, pois eram pessoas quase todas com boa formação, todas tinham nível superior, todas escreviam muito bem. Eu acho que de todos os lugares, o trabalho pedagógico era o melhor.

\section{Como você apoiava os professores na realização das praticas?}

Eu sempre procurei, desde que elas me procurassem, entender o material da melhor maneira possível. Nunca deixei de combinar, sempre apoiei mesmo, dando um suporte e se precisasse de algum suporte pedagógico, se elas viessem me perguntar algo, eu indicava um livro ou algum material e sempre pensando na prática delas e ouvindo muito elas, "a preciso fazer tal coisa aqui, se comprasse um brinquedo", então ouvindo muito o que elas precisavam, partindo mesmo da necessidade delas, por que, nem sempre a necessidade de um professor é igual a do outro, não da pra você numa escola "'fechar" as coisas, então compra o mesmo tipo de brinquedo para todo mundo, mesmo material para todo mundo, procurando sempre respeitar as particularidades de cada um.

No trabalho desenvolvido no CEI, o que te trazia satisfação e o que te trazia

\section{frustração?}

O que me trazia mais satisfação era a realização das atividades e a alegria das crianças, me dava muita satisfação receber os pais, adoravam o trabalho da escola, então, quando fazíamos festas tinha quase cem por cento dos pais participando, e isso 
era uma coisa que me trazia realização mesmo. Frustração, sabe que eu tive tão pouca frustração? Porém, acho que com relação às pessoas que não atendiam bem a comunidade, que não tinham a visão de atendimento e de acolhimento que não tratasse direito os pais, que não sabia lidar muito bem com isso, pois muitas vezes a gente tenta interferir ou conversa, mas, é muito difícil, pois, lidar com a criança nesse aspecto é fácil, mas com o adulto, você tentar passar para o adulto aquilo que você acredita é mais difícil, então algumas vezes que eu me frustrei, foi por isso, eu dizia que não, que tínhamos que entender e muitas vezes os professores por exemplo, funcionários em geral, não entendiam muito bem a proposta, achava que ''a, você que é muito mole', então se por exemplo eu abrisse uma exceção para um pai que chegou atrasado e o pai vinha e se justificava e as vezes era encarado como 'deixou a criança entrar mais tarde", essa rigidez com que as pessoas tratavam as coisas me causava uma frustração, não tinha que ser daquele jeito e a gente tinha um bom relacionamento com as famílias, eu falava isso com elas, que a gente tinha que reconhecer isso também.

\section{Agora eu gostaria que você falasse sobre o seu trabalho lá no CEI, o que} você gostava e o que você não gostava?

Olha, o trabalho que eu acho mais chato para o gestor é ter que cuidar da vida do outro então assim "a, fulano esta chegando todo dia atrasado", professora que falta muito, então assim essa coisa da falta de comprometimento, de você de ficar falando e as vezes ter tomar medidas antipáticas, como "não vou te dar abonada", "vou fazer todos os descontos possíveis", eu acho que pra mim, essa é a parte pior, ter que convencer o outro das obrigações dele é muito chato, agora, do resto eu acho que gostava de tudo, estava sempre envolvida com o pessoal mesmo no pedagógico, participando das coisas adorava vir nas festas, sempre vinha nas festas da escola, cuidava das verbas, gostava também, é trabalhoso e tudo mais mas eu acha que se tinha que fazer vamos fazer, até por que tinha até a questão de que hoje em dia você (diretor) é obrigado a usar um contador para cuidar das verbas da escola e até o ano passado não era obrigado e eu nunca contratei, pois achava que um dinheiro tão pequeno que a gente recebia, que na verdade, um contador ele consome um repasse todo de PTRF, nós recebemos 3 ao ano, então de 5 mil que eu economizava no ano para mim era um dinheiro enorme, para quem ganha 15, então eu sempre preferia, então, se me dava um trabalhão em compensação me dava mais prazer por que eu podia ir lá e comprar mais brinquedo, tinha mais dinheiro para gastar com o material, e uma das coisas ruins de 
escola é a manutenção, por que, escola da muita manutenção, o CEI é uma coisa de preocupação constante com segurança, com as crianças, acho que assim, a prefeitura tinha que dar mais atenção na questão do parque por exemplo, por que isso era uma frustração por que não conseguir arrumar do jeito que eu queria e que as professoras queriam, mais é um dinheiro muito grande.

\section{O que você julgava ser a sua atribuição no CEI?}

Eu acho que a parte da manutenção, trocar uma lâmpada, uma torneira que está estragada ou um cano entupido, mas, não seria da minha atribuição as questões relacionadas com segurança, tem que ter uma pessoa responsável que responda pela segurança no parque por exemplo, no pátio aberto, ou mesmo na hora da entrada, não da pra você todas as coisas, ter um vigia, teve uma época que eu saia na sexta-feira neurótica que na segunda eu ia chegar na escola e tinham roubado tudo, cada bem que você compra pra escola ta embutido naquele bem tanto trabalho, não é só uma questão de dinheiro ou custo mas, você tem que fazer orçamento, compra o bem, tem que fazer a incorporação daquele bem, toda uma papelada para em um final de semana vir uma pessoa e levar embora, e lá teve uma época que final de semana prolongado era uma tortura, e isso me desgastava por que não sou eu que tenho que ficar pensando na segurança, mesmo a segurança das crianças, tinha que ter um apoio maior, por que o diretor fica ali na escola então você corre atrás de uma coisa ou outra na hora da saída, uma criança corre para a rua, então você fica muito preocupado com algumas coisas que se tivesse um outro apoio não ficaria preocupado e relaxava para fazer melhor outras coisas.

\section{Como diretora do CEI, o que você acha que falta, o que esta consolidado e} como você gostaria que fosse?

Eu acho que o que já estava consolidado era nosso trabalho pedagógico, que estava bacana, tinha uma ou outra que ainda estava fora, mas, eu acho que tem a questão dos tempos de cada um, formação pessoal e profissional de cada um, a trajetória de cada pessoa, então, acho que o trabalho pedagógico estava bacana, de uma maneira geral, acho que estava "redondinho", acho que o que faltava era um comprometimento maior de todos. As professoras mesmo reclamavam, "a gente faz, o outro não faz, não da continuidade naquilo que eu fiz esse ano", então faltava um pouco de engajamento maior de algumas pessoas, eu acho que era isso de ter esse trabalho mais coeso mesmo, 
que eu acho que é o objetivo de todos, um trabalho mais coeso e de qualidade de todos, que é o grande sonho, e acho que na questão de sonhos mudar algumas coisas no prédio, fazer outras bem feitorias.

\section{E o PEA do ano passado, como surgiu?}

Foi uma continuação do PEA de 2012 que trabalha a questão do currículo que é um tema que não se esgota em um ano, é bem amplo, se deu pela continuidade por que o pessoal gostou, como elas haviam trabalhado por áreas no ano anterior foi um trabalho feito em cima do currículo em áreas, e então elas resolveram ampliar a discussão a respeito do currículo.

\section{Como era planejado o PEA?}

É feita uma avaliação ao final do ano, os pontos positivos e negativos, o que foi bom ou o que não foi, e a partir dessa avaliação se decide por um tema ou por outro tema, pela continuação, ai se faz o levantamento de bibliografias e sugestões, e até de outros temas que podem ser aproveitados dentro de um só que também tem que estar de acordo com o projeto pedagógico da escola. Todo mundo participava, o pessoal lá participa bastante, as pessoas que falavam que não participava era por que não queriam participar, sempre foi dado muita abertura não só da minha parte quanto da coordenadora pedagógica sempre teve abertura para todo mundo opinar mesmo e as pessoas lá já tem isso construído, então a pessoa participa e da suas sugestões, sempre partindo da avaliação do ano anterior.

\section{E como ocorria o PEA em si?}

Ocorre três vezes por semana, uma hora de horário coletivo, que elas fazem tanto de manhã quanto de tarde, período da manha das 7 as 8 e período da tarde das 18 as 19 , é obrigatório todas elas participaram, pela jornada do CEI todo mundo participa.

\section{Você vê alguma relevância no PEA?}

Sim, faz total diferença, por mais que tenha resistência de algumas pessoas, por mais que se aponte pontos negativos eu acho que ele é sempre importante, na verdade, ele esta ali sustentando todo um trabalho, eu trabalhei em alguns CEIs como coordenadora que não existia o horário coletivo, não existia o PEA, era muito difícil por que você não consegue ter esse espaço para discussões, então quando o PEA veio pro 
CEI foi de fundamental importância, é fundamental que ele ocorra, quem trabalhou onde não tinha esse horário sabe que as discussões não existem se você não tiver esse espaço.

\section{Você conseguiu perceber o impacto do PEA nas praticas pedagógicas dos professores com as crianças?}

Consegui. Bastante em alguns e um pouco menos em outras, era notório sim, mesmo aquelas pessoas que não estavam totalmente ligadas sempre tinham essa preocupação de em algum momento as discussões do PEA tinham que aparecer nas atividades, até por que depois você faz relatórios, então se fosse não está trabalhando aquilo que diz respeito ao PEA como você depois monta um relatório dos alunos?

Então acho que as coisas estavam mais “casadinhas" e eu via sim, não ficava só nas discussões, era levado pra sala de aula.

\section{E existia espaço para troca de experiência entre elas (professoras) no PEA.}

Sim, existia uma vez por semana, lógico que nada é tão "certinho", mas, existia sim, era até previsto na própria organização do PEA era previsto num dia da semana ou a cada quinze dias para troca de experiências, onde elas faziam o relato das experiências e que na avaliação das próprias professoras era um momento que elas gostavam bastante e achavam bem interessante e produtivo.

Sobre o PEA, o que você acha que falta, o que estava consolidado e o que você gostaria que fosse?

Acho que já tinha uma boa construção, estava bem organizado, os horários, eu acho que essa questão de ter os horários fixos pro PEA no CEI facilita até mais que na EMEI, o que eu achava que faltava muitas vezes é que uma hora pro PEA era pouco, e o que eu acho que dificultava é que era um número grande de professores pra fazer discussão então, acho que as vezes o PEA se tornava um pouco improdutivo pelo número muito grande de professores, as vezes eu fazia PEA com quinze professores, é muita gente, ou virava um debate muito caloroso ou tinha aquelas pessoas que não conseguiam participar por que a voz dela não conseguia chegar, então uma das coisas que dificulta o PEA no CEI é o número muito grande de professores. Acho que fazer o PEA com um número menor de professores, todos participam, mais não no mesmo dia, 
acho que seria mais interessante, apesar da gente pensar que o grupo se divide, não é o momento de decidir nada a gente vai discutir ideias, teorias, mais o que dificultava o PEA, uma hora não era o suficiente e a própria organização, um numero grande, até as pessoas conseguirem chegar todas até a mesa, até se organizar, sentar, se organizar e ter acomodação, você já perdeu um "tempão".

\section{Agora vou fazer algumas perguntas sobre o projeto político pedagógico, eu} queria que você me falasse da importância que ele assume para a instituição como um todo.

Com relação ao projeto político a gente ainda 'patina" um pouco e ainda fica um pouco esquecido, a gente não visita esse documento, não é igual ao PEA que é uma coisa viva, que você constrói ele no começo do ano, mas trabalha em cima dele o ano todo e muitas vezes o projeto pedagógico fica lá meio que esquecido, eu mesmo só incluía a minha parte de gestora, as expectativa para esse ano, coisas de compras, aquisições necessidades materiais mas eu acho que ainda é um documento que não é muito vivo dentro da escola, no CEI que eu trabalhava os professores até cobravam isso, fiz uma época até em duas vias para deixar na sala dos professoras pra de vez em quando você ir lá e visitar.

\section{Como ele era pensado e elaborado?}

Ele era na verdade todo ano colocado alguma coisa a mais, ele já partiu de alguns princípios, e em cima disso nos íamos colocando algumas coisas que são próprias da unidade, eu brincava com as professoras que eu achava que a gestão só podia ser democrática quando era para o lado dos professores quando estava para o lado dos pais já não era mais, ai você tinha que ser autoritário.

\section{Qual era o nível de participação das famílias, dos profissionais e das crianças?}

Muito pouca, essa participação está ainda bem longe, dos pais participarem dessa discussão da construção do projeto pedagógico, do PEA, acho que ainda a gente tem uma distancia, e não é nem por que a não queremos, é por que chega no começo do ano te dão prazos para entregar, "dia 28 de fevereiro você tem que entregar o seu PEA', e justamente nesse começo que tem " $N$ " coisas para você fazer e como você vai ficar reunindo pais e discutindo? Tudo que você vai discutir leva tempo e você tem os 
prazos e com pai não tem como você dizer "'vamos marcar uma reunião amanhã às 20:00 horas, então tudo isso tem que ser pensado, ainda mais com pai de crianças pequenas que tudo tem que ser bem calculado, bem planejado, por que eles tem que sabre com quem eles vão deixar os filhos deles, já são pais que deixam a criança em período integral, lá nos tínhamos uma boa participação dos pais nas festas, nas reuniões de formação, reuniões de pais eles compareciam muito, então a gente já tinha conseguido uma boa participação, mas, não efetivamente para discutir sobre o PEA ou o projeto político da escola, eu acho que nos levávamos alguma coisa da participação deles na hora de fazer essas construções, mas era por que nos levávamos em consideração muita coisa que eles nos diziam na reunião de pais, nos fizemos umas reuniões com os pais no período de adaptação então você acabe colocando essas coisas que eles trazem dentro do projeto.

\section{Em que medida as crianças eram consideradas no projeto pedagógico?}

Eu acho que as crianças não tinham participação diretamente, mas de acordo com aquilo que nos acreditamos que seja a infância e com o que nos achamos que é necessário para criança de 0 a 3,4 anos de idade eu acho que tudo que nos íamos pensar estava sempre voltado para as crianças dessa faixa etária.

Na sua percepção, qual a relação que há entre o que é proposto no projeto pedagógico e o que é feito na prática?

Se o PEA é uma coisa que chega, o projeto pedagógico nem tanto, por que algumas coisas que escrevemos é muito filosófico, muito teoria e que não chega na pratica e no dia a dia, eu tava falando par você que a gente se pauta pela gestão democrática, da participação dos pais, de ouvir e tem determinados momentos que não se encaixa.

Sobre os tempos e espaços na unidade, com base em que princípios que era organizado o trabalho pedagógico da unidade.

Eu acho que tinha varias questões para resolver quando a gente pensava na questão dos espaços, levar em conta o numero de crianças, o tipo de material, a disposição e organização dos espaços, eu acho que tava implícito ali uma concepção de criança, de infância, pensada para criança de 0 a 3 anos de idade que é complicado, não temos que pensar a EMEI e sim a criança que chega e que ainda não aprendeu a andar, e 
sempre esta mudando, tem que ser dinâmico, por que a sala que atende hoje crianças que chegam mau sabendo andar, daqui a três meses já está todo mundo andando e subindo em cima de tudo, então, tem que ter dinamismo mesmo, nada pode ser tão estático.

\section{Queria que você falasse um pouco da rotina do CEI, e como ela se organiza.} Quais os aspectos que você considera importante nessa rotina?

Toda a rotina do CEI é bem importante, acho que não tem como dizer o que é menos ou mais importante, pois tudo compõe, se você tira algo, vai faltar, a maneira que é pensada essa rotina é uma composição para que as coisas funcionem, quando uma coisa não funciona parece que todo o resto também não, então eu acho que o CEI tem essa questão, e eu achava bem impressionante como as professoras lidavam com isso e tinham isso tão bem organizado, a questão da rotina das crianças, de como fazer, e elas sempre discutiam muito, por que como estão em duplas tem essa coisa de a visão que uma tinha não ser a mesma da outra e se chegar a um senso comum de como vamos fazer, eu acho bem relevante, uma coisa que eu particularmente acho meio pesado era questão do sono das crianças maiores, na rotina o que eu acho que era e sempre algo difícil de discutir, era um ponto que sempre foi meio difícil, por que quando você propunha alguma coisa para mudar essa rotina por exemplo, será que todos eles precisam dormir no mesmo horário? Nos falamos tanto que as crianças não precisam fazer a mesma coisa ao mesmo tempo, não precisa dar a mesma atividade para todos os alunos iguais a todos, mais na hora do sono isso não funciona, querendo ou não, vai dormir, então eu acho que por eles serem tão pequenos e por passarem oito a dez horas dentro da escola eu acho que a rotina deles é uma rotina mais pesada para eles, então eu acho que algumas coisas poderiam ser mais flexíveis, o horário do sono, da refeição, nos tentávamos fazer algumas coisas diferentes, se nos um espaço mais amplo com menos alunos talvez nos conseguimos mais flexibilidade.

Como as crianças são consideradas nessa organização dos tempos e espaços da instituição?

Eu acho que eles não são muito levados em conta o tanto quanto merecem, por que muitas vezes tinha isso de nos dizermos: "a mais ele não quer comer agora", "então 
não da comida agora". Mas a cozinha é terceirizada e fecha "tal'" hora e depois desse horário não pode mais comer, então você fica preso com aquilo, '’a eu não quero dormir', mais se sai e faz barulho lá fora os que querem dormir não dormem. Então, eu acho que não era levado em consideração a questão da criança, em muitos momentos eles não queriam dormir e eram obrigados.

Eu queria que você dissesse ao que diz respeito a rotina do CEI, o que pode melhorar, o que falta e como você gostaria que fosse?

Eu acho que devia ter horários mais flexíveis de alimentação, tudo dentro de um padrão que é bom pra eles, a questão do sono, tinha que ser mais flexíveis com aqueles que não querem, principalmente no segundo semestre, pois as crianças no segundo semestre tinham outro interesses, não era a mesma criança que chegou no primeiro semestre, eles queriam fazer outras coisas, tem que se repensar isso. Acho que os espaços do CEI, por exemplo, com as professoras que tínhamos e com o comprometimento que elas tinham, se tivéssemos salas de aula mais amplas elas fariam coisas maravilhosas, se tem muita restrição pelo espaço da sala de aula. A questão de eles dormirem na sala, você acaba restringindo um monte de coisa, eu acho que isso podia melhorar, e acho que temos que ter mais participação das famílias, mesmo nas discussões de projeto, do PEA e tudo mais, por que não podemos achar que sabemos tudo, então acho que é bacana sim ouvir um pouco também, por que acho que tudo que teve de melhor e influenciou mais na qualidade do trabalho foram coisas que partiram dos pais, das próprias famílias e não de teorias. 


\section{APÊNDICE J - Roteiro de entrevista individual com a Coordenadora}

\section{Identificação:}

Identifique-se como você quiser, falando minimamente: seu nome, idade, nível de formação e experiências profissionais.

\section{Sobre o dia a dia profissional:}

1) Relate seu dia a dia no CEI, explicitando como ocorrem as comunicações entre as docentes e a gestão (diretora e coordenadora pedagógica) e as gestoras?

2) Como avalia o trabalho pedagógico da unidade? O que está bom e o que precisa melhorar em sua opinião?

3) Como você apoia os professores na realização de suas práticas?

\section{Ser coordenadora pedagógica:}

1) No trabalho desenvolvido no CEI, o que traz satisfação e o que traz frustração?

2) O que gosta e o que não gosta?

3) O que julga ser atribuição sua?

4) Como coordenadora pedagógica? O que falta? O que já está consolidado? Como gostaria que fosse?

\section{Sobre o processo de formação dentro do CEI:}

1) Como surgiu o projeto de formação (PEA) esse ano?

2) Como é planejado?

3) Como ocorre?

4) Qual é a relevância?

5) Que impactos você consegue perceber na prática com as crianças?

6) Existe espaço para a troca de experiências?

7) O que falta? O que já se consolidou? Como gostaria que fosse?

\section{Projeto político-pedagógico:}

1) Que importância assume para a instituição como um todo?

2) Como é pensado e elaborado?

3) Qual é o nível de participação das famílias, profissionais e crianças?

4) Em que medida as crianças e suas famílias são consideradas? 
5) Na sua percepção, que relação há entre o proposto e o realizado na prática?

\section{Sobre os tempos e espaços:}

1) Com base em que princípios é organizado o trabalho pedagógico da unidade?

2) Fale um pouco sobre a rotina do CEI e a forma como ela se organiza. Quais aspectos considera importantes nessa rotina?

3) Como as crianças são consideradas na organização dos tempos e espaços da instituição?

4) No que diz respeito à rotina: o que pode melhorar? O que falta? Como gostaria que fosse organizada?

\section{Sobre a prática pedagógica:}

1) O que pensa sobre a organização dos tempos e espaços nesta instituição?

2) Como é pensado o projeto político-pedagógico da unidade?

3) Em que medida o planejamento do trabalho com o agrupamento relaciona-se ao projeto da unidade?

4) Em sua opinião, quais os momentos da rotina diária do CEI que você julga mais marcantes? Por quê?

5) Como esses momentos aparecem em seu planejamento?

6) Como você concebe a rotina em seu planejamento? Em que elementos você se apoia?

7) Em que você pensa ao planejar seu trabalho?

8) Em que medida você consegue perceber a participação da criança e das famílias em seu processo de planejar?

9) Como o seu planejamento se encontra com os planejamentos de suas colegas do mesmo agrupamento?

10) Como vocês se organizam para planejar as ações para o mesmo agrupamento? Existe um planejamento comum para o agrupamento?

11) Em que medida você e sua parceira de trabalho conseguem concretizar o que planejaram para o período? Que dificuldades você encontra no desenvolvimento daquilo que planejaram?

12) Como são tratados os imprevistos em seu planejamento?

13) Como as professoras dos dois períodos trocam informações?

14) Como trocam experiências de práticas? 


\section{APÊNDICE L - Entrevista com a Coordenadora Pedagógica}

Eu gostaria que você se identificasse dizendo: nome, idade, nível formação e experiências profissionais.

Meu nome é MG, tenho 50 anos, estou na prefeitura desde 1986, minha formação é pedagogia, tenho duas Pós, e minha experiência foi na prefeitura e escolas particulares e trabalhei também na fundação Bradesco.

Queria que você me contasse um pouquinho do seu dia a dia, aqui no CEI, explicitasse como ocorrem as comunicações entre vocês e professora você e Diretora?

Meu dia a dia envolve toda parte burocrática, pois tem muita documentação todos os dias ,tem muitas coisas pra serem vistas, falta muito tempo também para dar conta de tudo, porque a exigência vem de última da hora e você tem que convencer a equipe que precisa ser feita, mas eu passo pelas salas todos os dias, converso com as professoras, converso bastante com as crianças, vou em diferentes espaços e diferentes momentos também, parque, solário, acompanho também o almoço o jantar e saída, gosto muito de fazer saída com os pais, eu acho que é importante esse contato. As comunicações com os professores eu tenho um livro registro que eu faço os comunicados por escrito, achei melhor porque era muito confuso discutir só no PEA depois não registrar isso, então eu costumo discutir no PEA e fechar no coletivo e depois eu coloco por escrito e elas tomam ciência. Com a diretora nós conversamos na hora e medida que vai sendo possível, nos não temos horários certos.

Como que você avalia o trabalho pedagógico da unidade, o que você acha que esta bom o que precisa melhorar?

Eu acho que as professoras tem muito empenho, eu tenho experiência do outro CEI e quando eu cheguei aqui já tinha muita coisa consolidada, por exemplo, as rodas de história, as rodas de musica, as atividades em salas diversificadas que elas fazem, então acho que muitas coisas elas já desenvolvem, elas são estudiosas, participam bastante dos cursos, não só pela pontuação, mas muitas vezes também pelo interesse por tema, o que eu acho que faz falta em algumas professoras é desenvolver mais o lado afetivo, acho que elas são muito duras com as crianças em alguns momentos eu tenho que intervir na questão, acho que de um modo geral isso a gente precisa trabalhar bastante e também fechar um pouco mais algumas práticas, por exemplo, atividades das 
salas ambientes do entorno, da culinária das rodas de musica dos circuitos. Acho que a gente já pode fechar isso.

Sobre a organização do trabalho pedagógico o que você avalia da organização?

Agora no final do ano a gente já faz uma avaliação do trabalho e com vista já para o ano que vem então já fechamos tema, o que vamos trabalhar. A avaliação do PEA, todo ano, eu faço individual, elas fazem por escrito e individual, no final do ano na ultima avaliação elas já avaliam como foi o trabalho do ano e já projetam para o ano seguinte, normalmente, eu escrevo o projeto e vou lendo com elas ai também eu fecho os filmes os textos e depois vou acompanhado se isso se revela lá na prática.

\section{Como você apoia os professores na realização das práticas?}

Eu acompanho, esse ano eu tenho acompanhado pontualmente nas salas a tarde, eu tenho entrado nas salas, tenho ajudado muito no dia a dia mesmo, esse ano fiz muito isso de passar o dia todo com a professora na sala, e no apoio dos materiais, dos espaço dos tempos, organização, por exemplo, os aniversariantes eu já vou organizando como vai ser com antecedência.

\section{Por quais motivos você acompanha mais o grupo da tarde?}

Porque eu entro 10h30min, esse horário as professoras já estão descendo par ao almoço, eu tenho acompanhado às vezes o almoço, vou lá converso um pouco com elas e depois vou até a sala durante um horário que elas acharam melhor por conta do sono das crianças, esse ano eu organizei uma pessoa para fazer essa ponte com o pessoal da manhã, para passar o que acontece a tarde, o que estamos combinando do coletivo então ela fica como minha porta voz, mas não tem dado muito certo.

\section{O que você considera que poderia melhorar?}

O ideal seria eu ficar os dois períodos no PEA, como era o ano passado, eu entrei aqui em 2011, e tinha alguns dias de manha com as professoras de manha e alguns dias a tarde, então dava para acompanhar e dava também para pontuar as dificuldades do pessoal da manha, eu sei que elas ficam sem um auxílio fica difícil e não dá para acompanhar a distância. Por mais que eu queira, eu tentei de todas as formas. 
No trabalho desenvolvido no CEI o que te traz satisfação e o que te traz frustração?

Tive muito medo de vir para o CEI, meu grande desejo era ir para o EMEI como coordenadora, porque toda minha experiência foi na EMEI, eu fui professora de EMEI quase 20 anos, então minha experiência na EMEI era muito grande e fui professora de educação infantil a vida toda, meu desejo quando eu me tornei coordenadora era esse, ser coordenadora de EMEI, eu fui por um período, mas eu tinha muito medo dos bebês, mas quando tive minha primeira experiência em CEI, foi uma experiência muito sozinha, porque foi a época que eu fiquei só, a diretora teve os dois bebês e ela ficou praticamente os 3 anos fora, então eu fiquei muito sozinha não tive uma parceira. Quando eu vim pra cá eu me descobri gostando muito do CEI, a primeira infância é o primeiro momento da criança fora da família, acho que é muito gostoso eu descobri um trabalho muito prazeroso. A dificuldade é em relação talvez a essa entrada do CEI na educação acho que não foi totalmente contemplada, muitas vezes os professores se sentem a parte da educação, então isso acaba gerando uma inquinação do corpo docente e isso é muito frustrante, acho que as professoras do CEI ainda não tem noção da importância do trabalho delas na vida dessas crianças, da importância do cuidado da conversa da afetividade.

\section{O que você julga ser a sua atribuição?}

O pedagógico, as famílias e as crianças essa é minha atribuição principal e tentar fazer uma parceria muito boa e tenho feito isso esse ano, eu sinto que as famílias têm uma confiança muito grande com a escola, porque problemas todo mundo tem e quando os problemas são vivenciados mais as famílias tem confiança é diferente, eu sinto que os pais tem confiança e acreditam no trabalho da escola. Acho que isso vem de muitos anos, a escola foi ganhando credibilidade no bairro, é uma escola de referência, os pais querem colocar as crianças aqui, lutam por isso, sinto que eles têm uma satisfação em ter os filhos aqui, falta ai um monte de coisas, mas eu acho que toda essa parceria vem ficando cada ano melhor. Acho que esse ano isso foi uma das conquistas.

Como coordenadora pedagógica o que você acha que falta aqui. O que já está consolidado e como que você gostaria que fosse? 
Eu acho que muitas práticas já estão consolidadas e várias professoras ainda não veem isso, elas não sentam isso, elas acham que para ser consolidado precisa todo mundo estar envolvido com tudo, não é assim porque as crianças ficam $10 \mathrm{~h}$ e as professoras $6 \mathrm{~h}$ algum momento que as crianças vivenciarem um ou outro na prática isso já está consolidado, eu entendo assim, então tem muita coisa que já está consolidado. $\mathrm{O}$ que falta talvez seja colocar isso de um jeito institucionalizado, talvez também trabalhar com as crianças a questão delas terem a consciência disso.

\section{E você gostaria que fosse exatamente como?}

Eu acho que muitas coisas já estão acontecendo, acho que em relação a outros CEIs, tem muita coisa que acontece nesse CEI que não acontece nos outros, acho que talvez tenha um pouco de professoras que não dividem as coisas por não querer dividir as coisas, socializar um pouco as coisas e entender que nos estamos aqui em função das crianças e não função de cada um. Eu posso ter uma experiência profissional, eu posso ter um sonho, posso ter desejos, mas meu papel aqui é ser o professor, então nesse momento eu tenho que estar voltado para a criança, eu acho que tem um pouco ainda de imaturidade, as pessoas desenvolverem práticas e esconderem, não socializarem existe também aquela idéia de pegar as coisas dos outros e colocar como sua isso também é uma coisa que precisa mudar bastante, falta um pouco de ética das práticas, as professoras aqui as professoras gostam de mostrar as práticas em congressos, gostam de participar dos cursos isso é bom porque poucas pessoas conhecem o trabalho do CEI, então precisa divulgar mesmo até entre os pais as famílias, mas tem essa coisa também pra divulgar eu escondo um pouco e coloco como meu, acho que é uma imaturidade profissional mesmo que precisa mudar, são muito jovens também tem uma coisa da carreira, elas querem construir, acho bacana também isso, eu acho que isso é muito positivo elas quererem estudar, mostrar trabalho, sentir orgulho de mostrar.

\section{Só que aqui no CEI elas não dividem muito ou não dividem?}

Não, umas não em função disso, elas mostrarem como seu não sei se isso é negativo, eu acho que é coisa talvez de não dividir mesmo, de não socializar os conhecimentos aqui, por exemplo, a F. é uma pessoa muito estudiosa, mas ela é muito mal vista no grupo, justamente por isso, ela gosta de mostrar os trabalhos dela e ai algumas professoras acham que a F. é exibicionista, ela é mal vista muitas vezes mas ela pode contribuir muito com o grupo contudo tem receio de falar e não ser bem vista, 
por isso. Por outro lado tem pessoas que poderiam contar e sente talvez menores porque não tem experiência, a F. apresenta pesquisas e não tem vergonha nem timidez nenhuma. Tem gente que poderia mostrar também tem coisas bacanas aqui e que elas ficam talvez envergonhadas. Aqui poucas pessoas se removem, esse ano foram quatro, então o grupo permanece o mesmo já bastante tempo, o grupo grande, maioria das pessoas, mas ao mesmo tempo elas se conhecem muito isso também gera uma competição, sinto que tem uma competição em alguns momentos aqui com algumas pessoas, elas competem muito pra mostrar no congresso, para aparecer, por exemplo, quando tem um espaço que elas podem mostrar o trabalho elas se inscrevem, eu acho bárbaro. Muitas vezes às pessoas para se inscrevem, tem que ter todo o incentivo do coordenador, então eu não tenho esse trabalho aqui elas se inscrevem voluntariamente, mas ao mesmo tempo tem aquela coisa da competição uma conhecem muito bem a outra, sabe a capacidade da outra, então elas não dividem os conhecimentos, para multiplicar, muitas vezes elas escondem, tem muito trabalho publicado da F., por exemplo, ela publica ela não tem receio ela escreve bem a maioria das professoras escrevem bem aqui, elas conseguem se colocar muito bem, elas têm uma formação pedagógica boa, mas isso poderia melhorar a prática da escola, contudo se eu escondo se eu guardo ai fica só pra mim.

\section{Quero saber como surgiu o projeto de formação esse ano aqui o PEA?}

Então eu estou aqui faz três anos, primeiro ano elas tinhas estudado "Amarelinho" linguagens "elas tinham feito um estudo" do PEA só sobre isso com a coordenadora anterior, quando eu cheguei elas acharam que natureza e sociedade e matemática era os temas que elas tinham deixado para o segundo semestre e elas não tinha conseguido estudar o suficiente, então o primeiro ano nos fizemos um PEA só sobre isso, sobre natureza, sociedade e matemática ainda dentro das linguagens do amarelinho. $\mathrm{O}$ ano passado era um desejo do grupo trabalhar currículo, mas no sentido de ter um currículo desses CEI, de escrever um documento mesmo, não só estudar os temas abrangentes, mas escrever um documento, ai nós estudamos o ano passado esse tema e como não foi o suficiente nós continuamos esse ano, assim o PEA surgiu do desejo do próprio grupo, mas uma dificuldade não é trabalhar linguagens, porque as linguagens as pessoas já trabalham muito bem aqui na escola, a minha dificuldade aqui foi mudar a postura e eu não consegui, eu tentei e através dos textos e trazendo para prática mudando um pouco as coisas da escola, por exemplo, até hoje elas colocam as 
crianças em mesas separadas no refeitório eu queria que as crianças pudessem escolher um lugar de sentar, porque nos temos três gêmeos e a irmãzinha esta na mesa do lado e querem ficar juntas e não podem às vezes eu não quero ficar com meu amigo da sala eu quero ficar com outro, elas ficam misturadas no parque nas salas, inclusive misturando os berçários com o mini-grupo II, isso elas não tem receio de misturar elas trabalham os grupos misturados, mas na hora da refeição elas não conseguem misturar as crianças, isso é uma coisa que eu queria que elas fizessem para que as crianças pudessem escolher o lugar para sentar, pudesse escolher com quem querem sentar e ai eu não consegui, porque elas tem essa coisa de saber se as crianças estão comendo, essa é a preocupação delas, saber se as crianças estão se alimentando direito e poder dar esse retorno na saída para os pais.

\section{Como é planejado o PEA?}

Coletivo, nos avaliamos o ano e projetamos para o ano seguinte o tema, as bibliografias eu sempre peço para elas trazerem e fechando o tema eu falo para elas trazerem sugestão, eu uso e também socializo antes de começar todos os temas, já elenco tudo que a gente vai estudar separo e mostro tudo com antecedência. Em fevereiro à gente faz tudo isso: prepara as bibliografias, organiza pelos temas nas ordens do ano todo, e elas sempre participam dessa organização dos temas, o ultimo item que eu coloco no PEA, é a bibliografia ela fica aberta para o que vai surgindo ao longo do ano, que muita coisa acontece e as coisas vão mudando, então algumas coisas que eu coloquei na bibliografia nos não cumprimos agora este ano por conta do rendimento e dos indicadores e outros foram entrando e surgindo ao longo do ano. Esse ano nos tivemos problema em relação a alimentação, as crianças que chegarem à escola e as mães amamentando criança grande e com maus hábitos, então isso foi uma coisa que eu fui trabalhando ao longo do ano no segundo semestre, fiz um PEA lá no parque com uma nutricionista que trabalha com alimentação saudável, ai eu fui trazendo livros, filmes nos tivemos também este ano uma nutricionista que veio falar com as mães no começo do ano para orientar, então as coisas que vão surgindo ao longo do ano são encaixadas, mas o grande tema ele é discutido em fevereiro no coletivo, final do ano tem avaliação .

\section{Como o PEA ocorre aqui na unidade?}


Três vezes por semana, tem o livro do PEA de manhã e de tarde, esse ano elas resolveram também separar porque tinha o livro único de registro, mas elas acharam melhor separa por turno, então este ano temos um livro da manhã e da tarde e nos vamos acompanhando o que já foi projetado para o ano a cada bimestre, nos lemos, discutimos e também tentamos trazer para prática, se estamos lendo um livro sobre espaço, e a gente vai discutindo como é nosso espaço na escola e tentando modificar, mas não é tão simples assim mudar a prática que já alguns anos está acontecendo.

E sobre o fato de você estar presente no PEA só um período, porque este ano você não conseguiu fazer o PEA nos dois períodos.

Não, eu fiz até abril nos tínhamos já mandado um horário do PEA, um horário nosso meu e da diretora, e eu tinha até abril eu fiquei uns dias com as professoras da manha e alguns dias com as professoras da tarde, mas em abril a diretora fez um pedido para a supervisora e a supervisora atendeu e eu passei a ficar somente a tarde, não foi nada bom porque não é fácil um coordenador coordenar só uma parte do grupo e outro não isso acabou dividindo a escola.

\section{Você acha que o estudo é prejudicado ou não?}

$\mathrm{Eu}$ acho que sim o que a gente tem feito é lido o registro do outro turno, isso a gente tem feito, na verdade eu tenho orientado as professoras da manha a lerem o registro da tarde antes de começar o estudo delas pra poder seguir juntas, mas não sei se isso aconteceu, acho que não.

\section{Qual a relevância do PEA na unidade?}

É muito importante o PEA, a formação é muito importante foi uma conquista a duras penas, lógico que muita coisa precisa mudar primeiro ano aqui eu consegui fazer uma coisa bem bacana em estudávamos as professoras levavam para sala para a prática e depois elas tinham um momento no PEA para a troca, nos chamávamos de oficina então elas podiam contar como elas eram muito boas em mídia, elas filmavam, elas fotografavam ,filmavam brincadeiras, por exemplo, trazia para o PEA e a gente conversava sobre aquilo, acontecia a cada quinze dias chamávamos de oficina e troca de experiência, tinha uma vez por semana um momento que elas podiam construir algum material para usar na sala de aula e outro dia elas tinham para trocar para contar um pouquinho como foi isso, então no primeiro ano foi muito importante, ano passado 
elas sentiram a falta disso e esse ano também elas colocam na avaliação que a gente não tem feito isso como muita frequência e do modo que nos conseguimos no primeiro ano, acho que foi uma coisa que tem que resgatar para o ano seguinte.

\section{Vocês não só construíam material como também trocavam experiência.}

Tinha um ou outro momento que tinha para construir o material, exemplo, foi quando nos trabalhamos com as águas elas fizeram experiência com bolinhas de sabão e ai nós fizemos juntas no PEA formatos diferentes estrelas, círculos e quadrados para as crianças experimentarem se as bolinhas sairiam em formato diferente, nos fizemos isso juntas no PEA, depois elas levaram para sala para testaram com as crianças e eram assim as experiência com água cada uma fez um tipo de experiência isso era legal a troca depois de cada uma contar como foi. Na experiência com água, por exemplo, isso em natureza e sociedade teve o berçário que fez uma pipa com jornal ai elas levaram para as crianças lá fora não deu nada certo, deu tudo errado e por uma criança que estava brincando com um saquinho de supermercado, elas perceberam que se fizesse com saquinho de supermercado daria mais certo, elas retomaram isso refizeram,foi super legal, isso faltou esse ano, essa coisa da troca entre elas, porque também tinha o olhar não só o meu, mas o olhar do outro sobre a prática que é a contribuição do outro, muitas horas antes da professora montar as outras iam dando ideias ia enriquecendo a experiência, isso foi muito bom, só consegui fazer durante o primeiro ano, ano passado não deu certo, acho que pode ter sido um erro meu mesmo, eu até cheguei a colocar no PEA, mas não consegui efetivar na prática e esse ano menos ainda por conta de não estar de manha e a tarde também isso é uma coisa que eu quero retomar para o ano que vem , acho que ajuda muito na experiência de todo mundo, porque cada uma tem uma experiência, tem uma professora aqui que trabalha em Taboão em outra prefeitura em Cotia, Osasco tem professores que trabalham no SESI, então tem outro tipo de experiência que pode socializar e enriquecer todo o grupo.

Sobre o PEA eu gostaria que você falasse o que você acha que falta, o que já está consolidado e como você gostaria que fosse?

Sobre o PEA eu acho que falta isso que eu acabei de falar, que nos fizemos o primeiro ano, falta trazer um pouco pra prática para socializar com todos, eu acho que falta talvez um pouco mais de compromisso nos horários, mas isso também é uma coisa 
que a gente vai aprendendo, eu acho que eu consegui esse ano fazer com que elas participarem melhor com o PEA com o grupo da tarde. Uma coisa bacana que aconteceu esse ano foi que eu trouxe um vídeo do Piaget, ai elas assistiram o vídeo e depois elas perceberam nas crianças o que foi relatado no vídeo, depois elas socializaram ai ficou bem legal deu para perceber nas práticas algumas teorias, porque uma coisa é a teoria outra a prática .Eu acho que o PEA é muito importante, mas tem que ser importante pra todos os professores tem que sentir que é momento de estudo delas, acho que é importante também os horários uma coisa que elas não usam o individual direitinho, não sei se nas outras escolas acontecem, mas na EMEI isso acontece muito à gente usa muito o horário individual para produzir materiais, para organizar os materiais das crianças e aqui o individual é um horário de lazer, tomar café, por a conversa em dia não são todas, algumas usam, por exemplo, a professora $\mathrm{C}$ eu vejo sempre ela usando o espaço discutindo, conversando, olhando relatório, olhando as agendas das crianças algum material, uma coisa que ficou mais, mas não são todas, a maioria fica passeando pela escola, talvez falte maturidade de entender que esses horários são importantes e depois não consegue dar conta de tudo.

\section{Em sua opinião qual a importância que o Projeto Político Pedagógico} assume na instituição como um todo?

$\mathrm{Na}$ instituição aqui ele quase não acontece, eu acho que o projeto político pedagógico ainda é só um documento aqui na escola um documento sendo entregue, não consegui ainda fazer ele na parte da prática, por exemplo, o ano passado o nosso PP era o mesmo tema do currículo e o mesmo tema do PEA era currículo também e nos colocamos junto com o plano de metas da escola, este ano por conta da paralisação é que ele virou um plano de meta e o projeto virou uma coisa da escola por conta da paralisação nos íamos fazer só o que tinha combinado com o período da tarde com os professores da tarde os professores da manha não iam participar, e tem muita coisa também que eu acho que ainda é assim é você que tem que fazer é uma coisa da gestão, por exemplo, elas acham que o projeto político é da escola e tem que ser abraçado por todos inclusive pelos funcionários tem que fazer parte da prática da escola e eu acho que ainda não é. Esse ano muitas coisas aconteceram, mas não do jeito que a gente queria.

\section{De fato como ele é pensado e elaborado?}


Juntos, tira-se o tema também do grupo só que eu faço o documento elaboro depois eu leio junto com elas e a gente vai mudando as coisas, mas ele fica só um documento escrito ele não se efetivou na prática esse ano, por exemplo, eu acho que era a reorganização dos espaços que estava casado com o currículo nos queríamos dentro de currículo organizar os espaços, algumas coisas aconteceram outras não, eu acho que falta uma alteração das gestoras de priorizar isso como da escola envolver o conselho da escola, eu acho isso importante, envolver o conselho no PP, ainda está muito desarticulado está mesmo só como um documento a mais.

\section{Em que medida as famílias participam?}

Este ano a gente tem feito a participação assim só chamamos as famílias para falar do filho que deu errado, porque tem esse livro vermelho que quando eu chamo as famílias eu sempre registro, então ele já estava aqui na escola, mas eu tinha um assim lá na outra e eu dei continuidade aqui. Todas as vezes que a gente precisa chamar uma mãe uma família pra falar sobre um problema que esta acontecendo em relação à criança à gente registra nesse livro pra poder depois saber o que foi combinado e se foi feito, porque são muitas famílias. Agora as famílias a gente chama para a reunião de pais na reunião de pais a gente sempre fala muito, mais sobre o que eles devem fazer do que houve, este ano com a paralisação também, eu coloquei umas coisas assim, por exemplo, pais para vivenciar o projeto entorno aqui, nos chamamos os pais pra eles vivenciarem a história nos passamos todos os vídeos da fundação Vitor Civita pra eles entenderem porque nos contamos histórias para as crianças, dessa maneira nos discutimos com eles, então eu acho que as famílias precisam ser chamadas pra isso para participar e pra entender qual o nosso trabalho aqui também, para opinar sobre isso, ainda não está acontecendo isso, a gente chama pra contar sobre o que acontece aqui, mas poucos deles opinam, também acho que no conselho é um espaço que eles podem sim opinar, agora nos vamos fazer os Indicadores de qualidade, vou convidar os pais para participar, mas para opinar sobre a prática da escola ainda não.

Eu queria saber qual é a relação entre o proposto e o concreto, o que acontece na prática em relação ao que é posto no Projeto Político da unidade?

Como eu falei acontece muito pouco, muito de chamarmos as pessoas para participar mesmo não de ser voluntário não que as pessoas estão preocupadas de colocar 
esse documento na prática, tem que ter muita conversa para que isso vá acontecendo, mas isso tem muito pouco resultado para muita conversa.

E você vê alguma relação entre o trabalho dos professores, da pratica pedagógica com o que está posto, o que vocês pensaram no projeto político e a prática?

Não, não há, por exemplo, autonomia é uma coisa das crianças que esta no projeto a criança como protagonista está no nosso projeto, mas não acontece na prática, eu acho que acontece a autonomia que o professor quer que aconteça aquele que ele dá espaço, eu acho que tem professores que ficam preocupados, por exemplo, a A e uma professora que se preocupa muito em dar voz às crianças, isso é uma coisa que está no nosso P ela se preocupa muito com isso ela até sofre em alguns momentos, senta-se aqui no final do dia e conversa comigo e fala "hoje fui muito difícil eu não consegui fazer com que as crianças pudessem explorar mais", "hoje eu gritei com eles perdi a paciência eu não queria ter perdido a paciência com eles", então isso é uma preocupação da A. Isso é uma coisa que está no nosso PP, por exemplo, autonomia, dar voz as crianças, a questão de deixar as crianças em algum momento para o ósseo não ter tanta atividade dirigida tão organizada, deixar que em alguns momentos eles façam as próprias escolhas ou que eles fiquem até quietos, então esse ano eu estive bastante com as professoras, muitas crianças às ficam paradas só olhando as outras brincarem, elas não estão deixando de aproveitar olhando, mas muitas vezes o professor vai lá e faz a criança sair desse momento de olhar para brincar, muitas vezes a gente não quer fazer nada, quer ficar olhando o outro, e eu acho que essa carga para a criança ficar $10 \mathrm{~h}$ e muito intensa, precisa deixar em alguns momentos as crianças mais livres mesmo, se eles não quiserem fazer nada.

\section{Com base em que princípios são organizados os tempos e espaços na} unidade?

Nós temos a linha do tempo, eu entendo que algumas coisas não dá mesmo para acontecer, porque eles ficam muito tempo em refeição, ficam muito próximo uma da outra e a cozinha precisa estar organizada, então os tempos e os espaços eles não acontecem do modo que nos gostaríamos no pedagógico, eles acontecem por uma questão de organização da escola a criança que gastaria, por exemplo, mais tempo 
brincando no parque às vezes não pode porque ela tem que entrar para jantar ou aquela criança que está hiper envolvida naquela atividade de pintura ela tem que parar porque tem que lanchar, então essa organização quebra um pouco o pedagógico.

Quero que você fale um pouco da rotina aqui do CEI a forma que ela se organiza e quais os aspectos que você considera importante nessa rotina?

Eu acho que a rotina está um pouco engessada por conta da cozinha, teria que repensar melhor essa rotina para deixar ela mais flexível, talvez para que a criança não tenha uma rotina tão maçante, eu acho que é bem maçante para a criança, em questão dos horários, do repouso, da entrada e da saída. Uma coisa que nos também tentamos mudar no regimento foi o período de adaptação que aqui nos fazemos de um jeito bem legal, os pais no momento que as crianças estão sendo atendidos os pais também estão sendo atendido esse ano nos passamos documentários a gente passou a rotina da escola as práticas através dos vídeos e nos não pudemos colocar período de adaptação eles ate falaram que eles sabem que acontecem eles acham importante, mas que a gente não poderia colocar, porque na prefeitura não existe isso, eles disseram que é direito da criança ficar às $10 \mathrm{~h}$ na escola e ela tem que ficar $10 \mathrm{~h}$ na escola, às vezes a mãe pede para entrar um pouquinho depois nem todas as professoras gostam, mas elas entram tem mãe que entra um pouco mais tarde tem mãe que tira a criança um pouco mais cedo, porque ela está vinda do serviço e ai é caminho ela passa e tira então tem mãe que sai junto com os das peruas, por exemplo, há essa flexibilidade nos horários eu acho que é bom para o bem estar da criança e das famílias também a gente não precisa ter tudo engessado, eu acho que hoje ainda é muito pesado para as famílias e para as crianças. Mas aqui é difícil, em três anos eu tive três supervisores, cada supervisor me orientou de uma forma e não deixam a gente mudar a rotina de maneira alguma, eu inclusive comentei isso com a $\mathrm{MN}$, ela disse "se vocês quiserem vocês podem mudar" não é tão simples assim os supervisores virem e falar que tem que fazer assim. Um exemplo agora é o regimento que nos estávamos todos juntos uma coisa que eu coloquei em nosso regimento e passou, mas não sei se passou despercebido, porque já foi para homologação coloquei em um dos itens darem voz às crianças, ouvir as crianças nas questões pedagógicas e da escola eu coloquei isso para os professores alguns concordaram outros não concordaram outros acharam que não era possível as crianças comentarem e darem opiniões sobre os espaços delas, claro que é possível às crianças fazem isso o tempo todo elas contam pra gente por exemplo, lá no berçarinho, mesmo 
sem saber falar direito eles tem opiniões comunicam as coisas que estão acontecendo não sei se eles falam errado ou certo, é possível consultar as crianças e é possível ouvir eles, teve supervisor que fez um discurso dizendo que as crianças não têm condição de falar sobre nada que eles são muito inocentes, que eles não podem opinar sobre nada que a gente que precisa falar para eles de como tem que ser as coisas ele ainda está na concepção da criança incapaz.

Como as crianças são consideradas na organização dos tempos e dos espaços na unidade?

Eu acho que na maioria das vezes elas não são consideradas, eu acho que o professor decide mesmo e elas fazem, algumas professoras consideram, mas a maioria decide por elas o que vai ser feito, como vai ser feito, em que dia, em que hora e isso vai com a nossa PP do que está no documento que fica na prática.

No que diz respeito à rotina o que pode melhorar nessa rotina como você acha que poderia ser organizada?

$\mathrm{Eu}$ acho que tem coisa que se a gente quiser mudar na rotina como grupo é possível, mas precisa envolver todos os funcionários e não só colocar no papel, as pessoas não conseguem colocar na prática aquilo que está no papel de pensar na criança de organizar essa rotina de acordo com a criança de modificar um pouquinho essa prática para que a criança seja melhor atendida. 


\title{
ANEXOS
}

\section{ANEXO A - Termo de consentimento}

\section{TERMO DE CONSENTIMENTO LIVRE E ESCLARECIDO}

\begin{abstract}
À Unidade
$\mathrm{Eu}$ compreendo os direitos dos participantes da pesquisa provisoriamente intitulada "A natureza do trabalho cotidiano de quatro professoras de um mesmo agrupamento no contexto de um Centro de Educação Infantil da cidade de São Paulo", orientada pela Prof. ${ }^{\text {a }}$ Dr. ${ }^{\text {a }}$ Mônica Appezzato Pinazza, e que tem como pesquisadora responsável Lídia Silva Guimarães Godoi, da Faculdade de Educação da Universidade de São Paulo, as quais podem ser contatadas pelo e-mail mapin@usp.br / lidiaemurilo@hotmail.com ou telefone 988623744. Na qualidade de responsável por essa instituição, autorizo a realização do estudo nessa unidade. Compreendo como e porque ele está sendo realizado. Os responsáveis pela pesquisa garantem sigilo absoluto, assegurando a privacidade dos sujeitos quanto aos dados envolvidos na pesquisa. Receberei uma cópia assinada desse formulário de consentimento.
\end{abstract}

São Paulo de de 2013.

(Diretora CEI)

(Coordenadora Pedagógica- CEI) 
- FEUS

FACULDADE DE EDUCAÇÃO DA USP 


\section{ANEXO B - Termo de autorização para gravação de voz}

\section{TERMO DE AUTORIZAÇÃO PARA GRAVAÇÃO DE VOZ}

$\mathrm{Eu}$,

, depois de entender como e porque a pesquisa intitulada provisoriamente "A natureza do trabalho cotidiano de quatro professoras de um mesmo agrupamento no contexto de um Centro de Educação Infantil da cidade de São Paulo" está sendo realizada e entender especialmente os métodos que serão usados para a coleta de dados, assim como estar ciente da necessidade da gravação de minha entrevista, AUTORIZO, por meio deste termo, a pesquisadora Lídia Silva Guimarães Godoi a realizar a gravação de minha entrevista sem custos financeiros a nenhuma parte.

Esta AUTORIZAÇÃO foi concedida mediante compromisso da pesquisadora acima citada em garantir-me os seguintes direitos:

1. Poderei ler a transcrição de minha gravação;

2. Os dados coletados serão usados exclusivamente para gerar informações para a pesquisa aqui relatada e outras publicações dela decorrentes, quais sejam: revistas científicas, congressos e jornais;

3. Minha identificação não será revelada em nenhuma das vias de publicação das informações geradas;

4. Qualquer outra forma de utilização dessas informações somente poderá ser feita mediante minha autorização;

5. Serei livre para solicitar a posse da gravação e transcrição de minha entrevista.

São Paulo, de de 2013.

Assinatura do (a) participante da pesquisa

Assinatura da Pesquisadora

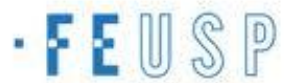

FACULDADE DE EDUCAÇÃO DA USP 
ANEXO C - Termo de autorização para uso de imagem

\section{TERMO DE AUTORIZAÇÃO PARA USO DE IMAGEM}

$\mathrm{Eu}$,

AUTORIZO o uso da minha imagem para fins de gerar informações para a pesquisa provisoriamente intitulada "A natureza do trabalho cotidiano de quatro professoras de um mesmo agrupamento no contexto de um Centro de Educação Infantil da cidade de São Paulo"e outras publicações dela decorrentes, quais sejam: revistas científicas, congressos e jornais. Por meio deste termo, a pesquisadora Lídia Silva Guimarães Godoi poderá utilizá-la para fins de divulgação, tanto em mídia impressa (livros, revistas, jornais, entre outros) como mídia eletrônica (documentários, vídeo, bancos de dados informatizados, entre outros).

Por ser essa a expressão da minha vontade, declaro que autorizo o uso acima descrito, sem que nada haja a ser reclamado a título de direitos conexos a minha imagem (fotos, vídeos, dados biográficos).

São Paulo, de de 2013. 
ANEXO D - Comunicação sobre a pesquisa

\section{PROGRAMA DE PÓS-GRADUAÇÃO \\ MESTRADO EM EDUCAÇÃ O \\ ÁREA: DIDÁTICA, TEORIAS DE ENSINO E PRÁTICAS ESCOLARES \\ MESTRANDA: Lídia Silva Guimarães Godoi \\ ORIENTADORA: Prof. ${ }^{a}$ Dr. ${ }^{a}$ Mônica Appezzato Pinazza}

\section{COMUNICAÇÃO SOBRE A PESQUISA}

Prezadas professoras de Educação Infantil.

Comunico por meio do presente documento sobre a pesquisa em nível de Mestrado que atualmente desenvolvo junto ao Programa de Pós-Graduação em Educação da Universidade de São Paulo, sob a orientação da Prof. ${ }^{a}$ Dr. ${ }^{a}$ Mônica Appezzato Pinazza. A pesquisa tem como principal objetivo investigar, no contexto do CEI, a natureza do trabalho cotidiano de um agrupamento sob a responsabilidade de quatro profissionais.

Agradeço sua colaboração e me coloco à disposição para maiores esclarecimentos. Obrigada.

Lídia S. G. Godoi lidiaemurilo@hotmail.com Agosto de 2013. 


\section{ANEXO E - Termo de consentimento \\ TERMO DE CONSENTIMENTO LIVRE E ESCLARECIDO}

\section{Aos sujeitos participantes da pesquisa}

Entendo que a pesquisa incluirá registros escritos, fotográficos, vídeos de meus alunos e de minha atuação em sala de aula. Compreendo também que a minha identidade não será revelada e autorizo a transcrição, leitura, análise e divulgação dos dados obtidos.

( ) concordo ( ) não concordo em participar do estudo conduzido pela pesquisadora

Lídia Silva Guimarães Godoi.

Assinatura:

Nome:

Data: 
ANEXO F - Termo de autorização para Utilização de imagem e áudio

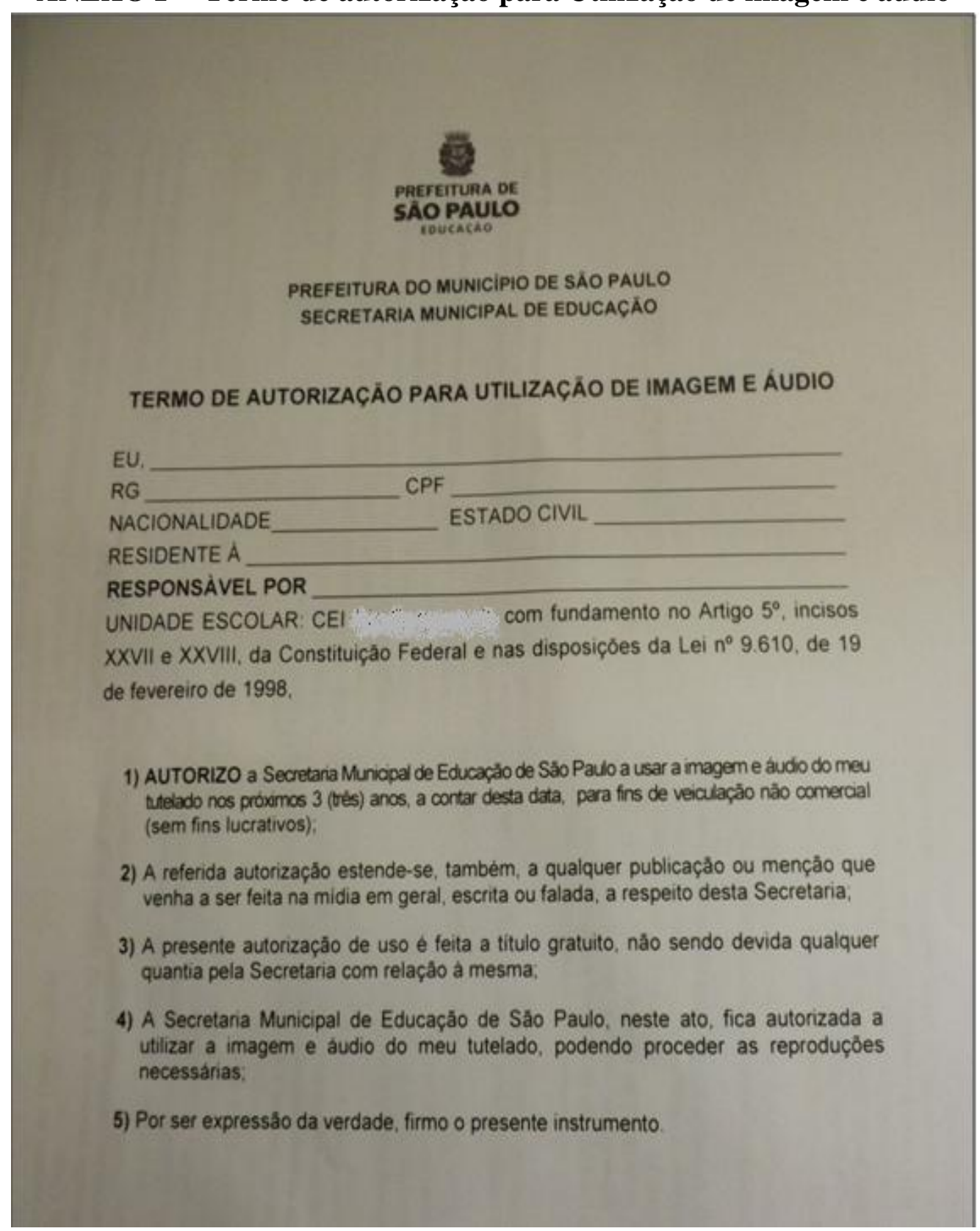

